\title{
Juventudes nos (entre)lugares: leituras interdisciplinares contemporâneas
}

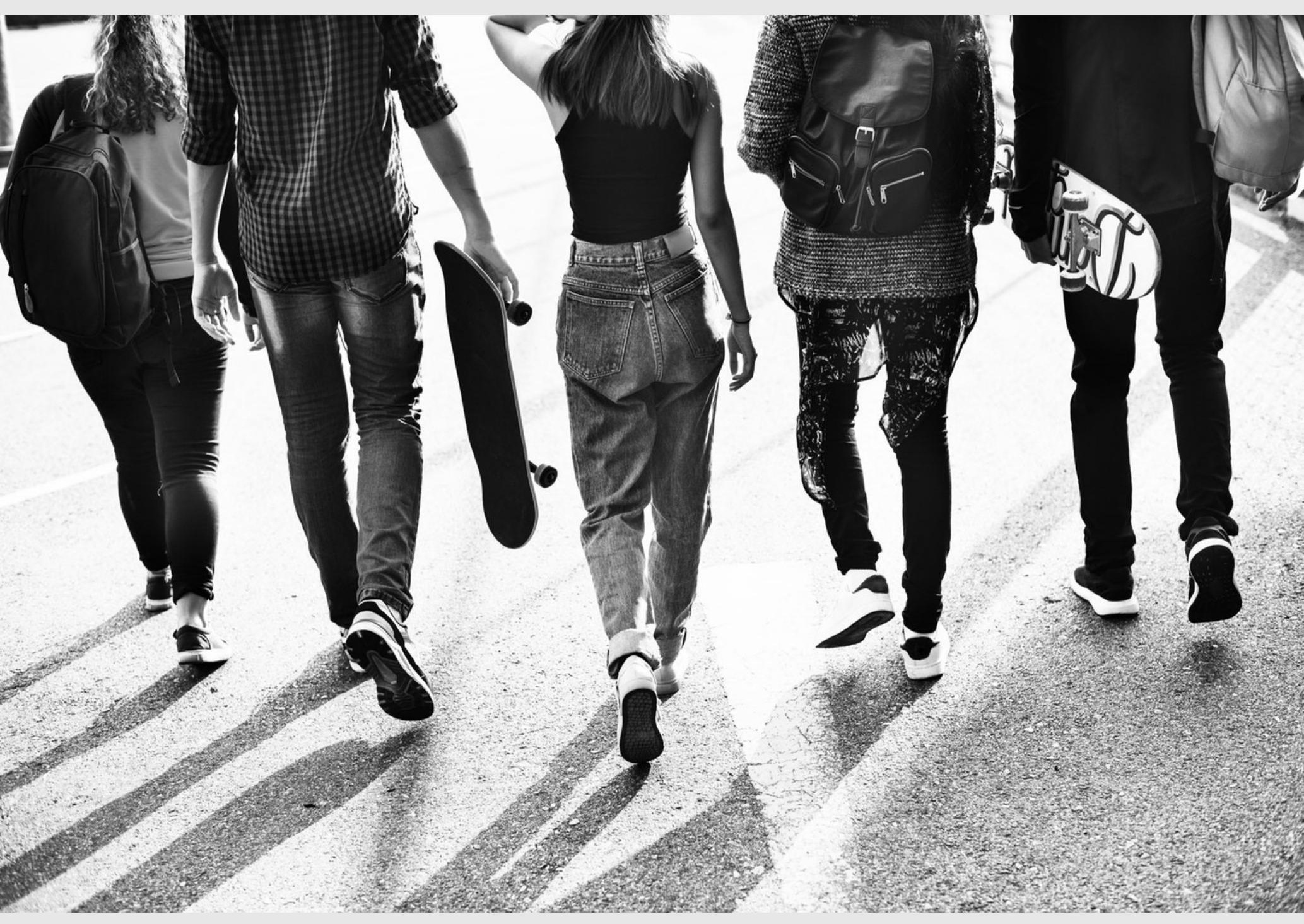

Rafael Ribeiro dos Santos

Mary Anne Vieira Silva

(Organizadores)

\section{Aर $C ?$ \\ EDITORESOO}




\section{CONSELHO EDITORIAL}

Prof. Dr. Adilson Tadeu Basquerot e Silva

UNIDAVI/SC

http://lattes.cnpq.br/8318350738705473

Profa. Msc. Jesica Wendy Beltrán

UFCE- Colômbia

http://lattes.cnpq.br/0048679279914457

Profa. Dra Fabiane dos Santos Ramos UFSM- Santa Maria/RS

http://lattes.cnpq.br/0003382878348789

Dr. João Riél Manuel Nunes Vieira de

Oliveira Brito

UAL - Lisboa- Portugal.

http://lattes.cnpq.br/1347367542944960

Profa. Dra. Alessandra Regina Müller Germani

UFFS- Passo Fundo/RS

http://lattes.cnpq.br/7956662371295912

Prof. Dr. Everton Bandeira Martins

UFFS - Chapecó/SC

http://lattes.cnpq.br/9818548065077031

Prof. Dr. Erick Kader Callegaro Corrêa UFN- Santa Maria/RS

http://lattes.cnpq.br/2363988112549627

Prof. Dr. Pedro Henrique Witchs

UFES - Vitória/ES

http://lattes.cnpq.br/3913436849859138

Prof. Dr.Thiago Ribeiro Rafagnin UFOB

http://lattes.cnpq.br/3377502960363268
Prof. Dr. Mateus Henrique Köhler UFSM- Santa Maria/RS

http://lattes.cnpq.br/5754140057757003

Profa. Dra. Liziany Müller Medeiros

UFSM- Santa Maria/RS

http://lattes.cnpq.br/1486004582806497

Prof. Dr. Camilo Darsie de Souza

UNISC- Santa Cruz do Sul/RS

http://lattes.cnpq.br/4407126331414

Prof. Dr. Dioni Paulo Pastorio

UFRGS - Porto Alegre/RS

http://lattes.cnpq.br/7823646075456872

Prof. Dr. Leonardo Bigolin Jantsch

UFSM- Palmeira das Missões/RS

http://lattes.cnpq.br/0639803965762459

Prof. Dr. Leandro Antônio dos Santos

UFU- Uberlândia/MG

http://lattes.cnpq.br/4649031713685124

Dr. Rafael Nogueira Furtado

UFJF- Juiz de Fora/MG

http://lattes.cnpq.br/9761786872182217

Profa. Dra. Angelita Zimmermann

UFSM- Santa Maria/RS

http://lattes.cnpq.br/7548796037921237

Profa. Dra. Francielle Benini Agne

Tybusch

UFN - Santa Maria/RS

http://lattes.cnpq.br/4400702817251869

Copyright (c) Arco Editora, alguns direitos reservados.

Copyright do texto (c) 2021 os autores e as autoras.

Copyright da edição (c) 2021 Arco Editora. 
Diagramação e Projeto Gráfico : Gabriel Eldereti Machado

imagem capa: https://fronteirasxxi.pt/cativarosjovens/

Revisão: dos/as autores/as.

Dados Internacionais de Catalogação na Publicação (CIP) (Câmara Brasileira do Livro, SP, Brasil)

Juventudes nos (entre) lugares [1ivro eletrônico] : leituras interdisciplinares contemporâneas / Rafael Ribeiro dos Santos, Mary Anne Vieira Silva [organizadores]. -- Santa Maria, RS :Arco Editores, 2021.

PDF

ISBN 978-65-89949-40-4

1. Educação 2. Educação - Finalidades e objetivos 3. Interdisciplinaridade na educação 4. Juventude 5. Leituras I. Santos, Rafael Ribeiro dos. II. Silva, Mary Anne Vieira.

$21-88858$ CDD-370. 1

Índices para catálogo sistemático:

1. Interdisciplinaridade : Educação 370.1

Maria Alice Ferreira - Bibliotecária - CRB-8/7964

\section{$10.48209 / 978-65-89949-40-4$}

O padrão linguístico-gramatical, bem como o sistema de citações e referências bibliográficas são prerrogativas de cada autor. Da mesma maneira, o conteúdo e teor de cada capítulo é de inteira e exclusiva responsabilidade de seu respectivo autor. 
"A juventude constitui um momento determinado, mas que não se reduz a uma passagem. Ela assume uma importância em si mesma como um momento de exercício de inserção social. Nesse, o indivíduo vai se descobrindo e descortinando as possibilidades em todas as instâncias de sua vida, desde a dimensão afetiva até a profissional. Essa realidade ganha contornos próprios em contextos históricos, sociais e culturais distintos. As distintas condições sociais (origem de classe e cor da pele, por exemplo), a diversidade cultural (as identidades culturais e religiosas, os diferentes valores familiares etc.), a diversidade de gênero (a heterossexualidade, a homossexualidade, a transexsualidade, por exemplo) e até mesmo as diferenças territoriais se articulam para a constituição dos diferentes modos de vivenciar a juventude". (DAYRELL; CARRANO, 2014, p. 112) ${ }^{1}$

1 DAYRELL, Juarez; CARRANO, Paulo. Juventude e ensino médio: quem é este aluno que chega à escola. In: DAYRELL, Juarez; CARRANO, Paulo; MAIA, Carla Linhares (orgs.). Juventude e ensino médio: sujeitos e currículos em diálogo. Belo Horizonte: Editora UFMG, 2014, p. 101-133. 


\section{SUMÁRIO}

PREFÁCIO

.8

APRESENTAÇÃo

12

Rafael Ribeiro dos Santos

Mary Anne Vieira Silva

CAPÍTULO 1

JUVENTUDES E CIDADE: UMA LEITURA ACERCA DAS PRÁTICAS ESPACIAIS E DA CONDIÇÃO JUVENIL...................................................20

Rafael Ribeiro dos Santos

Mary Anne Vieira Silva

doi: 10.48209/978-65-JUVEN-40-1

\section{CAPÍTULO 2}

A CIDADE E AS JUVENTUDES: SOCIALIZAÇÕES, RESSIGNIFICAÇÕES E OS DESAFIOS DOS JOVENS NO ESPAÇO URBANO............................34

Marco Antônio Oliveira Lima

doi: 10.48209/978-65-JUVEN-40-2

\section{CAPÍTULO 3}

GEOGRAFIA E JUVENTUDES: É DE PLURALIDADES QUE SE FALA!.....49

Carla Pizzuti Savian

Naomi André Cambará Barbosa

Benhur Pinós da Costa

doi: 10.48209/978-65-JUVEN-40-3

\section{CAPÍTULO 4}

CORPOS MIDIÁTICOS CONSTITUINDO AS JUVENTUDES

Katiele Hundertmarck

doi: 10.48209/978-65-JUVEN-40-4 


\section{CAPÍtulO 5}

TERRITÓRIOS SUBJETIVOS DE UM COLETIVO DE JOVENS NA PERIFERIA DE PORTO ALEGRE.

\section{Bruna Molina Leal}

Rosemarie Gartner Tschiedel

Nair Iracema Silveira dos Santos

doi: 10.48209/978-65-JUVEN-40-5

\section{CAPÍTULO 6}

A TERRITORIALIZAÇÃO JUVENIL NO/DO PARQUE AMBIENTAL IPIRANGA EM ANÁPOLIS (GO).

Jefferson Dias Andrade de Jesus

Mary Anne Vieira Silva

Rafael Ribeiro dos Santos

doi: 10.48209/978-65-JUVEN-40-6

\section{CAPÍtULO 7}

AS JUVENTUDES E O FUTURO: (RE)PENSANDO PROCESSOS EDUCACIONAIS COM A ESCOLA DE HOJE.......................................118

Luís Paulo Cruz Borges

doi: 10.48209/978-65-JUVEN-40-7

\section{CAPÍTULO 8}

EDUCAÇÃO FÍSICA ESCOLAR PELA REPRESENTAÇÃO DE JOVENS NO ENSINO MÉDIO.

Brunna Thais Reis Sales

Cláudia Valente Cavalcante

doi: 10.48209/978-65-JUVEN-40-8

\section{CAPÍTULO 9}

OLHARES DE JOVENS EGRESSOS DO ENSINO MÉDIO: REFLEXÕES SOBRE OS ENLACES NA ESCOLA.

Bianca Isabel Pederiva

Suzana Feldens Schwertner

doi: 10.48209/978-65-JUVEN-40-9 


\section{CAPÍTULO 10}

EDUCAÇÃO DO/NO CAMPO E A JUVENTUDE QUE O HABITA

Gracielle de Souza Silva

Joana D'arc Bardella Castro

doi: 10.48209/978-65-JUVEN-40-0

\section{CAPÍTULO 11}

JUVENTUDE, MOVIMENTOS SOCIAIS E EDUCAÇÃO: A PARTICIPAÇÃO POLÍTICA DOS JOVENS NAS OCUPAÇÕES ESTUDANTIS EM GOIÁS...182

Amanda Beatriz Silva de Godoi

Rafael Ribeiro dos Santos

Rita Castorina Gonçalves Gundim Lemes

doi: 10.48209/978-65-JUV11-40-1

\section{CAPÍTULO 12}

A PARTICIPAÇÃO DOS JOVENS POR MEIO DA MÚSICA SERTANEJA NA FOLIA DE SANTOS REIS EM ANÁPOLIS, GOIÁS 201

Mirelle Antônia Souza Freitas

Ademir Luiz da Silva

doi: 10.48209/978-65-JUV12-40-1

\section{CAPÍTULO 13}

TRAVESSIAS NOS (ENTRE)LUGARES: OS CAMINHOS DA JUVENTUDE EM TEMPOS PANDÊMICOS.

Tereza Caroline Lôbo

João Guilherme da Trindade Curado

doi: 10.48209/978-65-JUV13-40-1

SOBRE OS ORGANIZADORES 


\section{PREFÁCiO}

O convite vindo dos organizadores da presente obra para escrever este "Prefácio" deixou-me feliz, por dois motivos principais. O primeiro diz respeito ao reconhecimento do seu esforço em publicar este trabalho - que é sinalizador da tendência de configuração do campo de pesquisas sobre Jovens e Juventudes no Brasil.

Vale lembrar que o livro sempre foi um instrumento privilegiado, embora não único, de registro e difusão do conhecimento. Contudo, sua publicação, embora seja uma tarefa nobre, não é simples. Trata-se de um empreendimento desafiador, pois exige esforço intelectual, envolve o trabalho coletivo e requer a superação de alguns enfrentamentos, inclusive quanto à distribuição.

Além disso, vivemos hoje um tempo de popularização de revistas on-line e, sobretudo, de produtivismo acadêmico desmedido de nosso tempo, que valoriza a publicação de artigos em periódicos indexados, engendrada por agências financiadoras/concedentes de auxílios à pesquisa e de bolsas e seu modelo de avaliação. Diante disso, podemos dizer, corroborando o pensamento de Antunes (2018), que o livro tem se tornado "fora de moda" para os organismos dominantes de mensuração acadêmica e pontuado cada vez menos para os órgãos de fomento à pesquisa. ${ }^{1}$ Portanto, este livro é, em alguma medida, uma forma de resistência a esse modelo de regulação e controle da produtividade acadêmica, que segue a lógica do mercado no capitalismo atual.

O segundo motivo tem a ver com o fato de permitir-me retomar algumas questões sobre as quais me debrucei na pesquisa de doutorado ${ }^{2}$ e em outros

1 ANTUNES, Ricardo. O privilégio da servidão: o novo proletariado de serviços na era digital. São Paulo: Boitempo, 2018. Disponível em: https://nestpoa.files.wordpress.com/2019/09/ ra-ps.pdf. Acesso em: 13 dez. 2021.

2 PIRES, Lucineide Mendes. Culturas geográficas de alunos-jovens: uma referência para a formação de professores de Geografia. 2013. 276 f. Tese (Doutorado em Geografia) - Programa de Pós-Graduação em Geografia, Instituto de Estudos Socioambientais, Universidade Federal de Goiás, Goiânia, 2013. Disponível em: https://repositorio.bc.ufg.br/tede/handle/ tede/4194. Acesso em: 13 dez. 2021. 
textos que publiquei, ${ }^{1}$ acerca dos jovens e de sua relação com a cidade. Trago aqui algumas dessas questões: o que é "ser jovem"? Como os jovens vivem a sua condição juvenil? Em que medida o contexto espacial em que os jovens estão inseridos influencia na constituição da condição juvenil? Quais são os elementos constitutivos da cultura geográfica desses jovens? Quais as práticas espaciais (cotidianas e as dos finais de semana) comuns aos jovens? Como os jovens compreendem e apreendem a cidade? De que forma eles experienciam a cidade e se apropriam de seus espaços? Qual a complexidade sociocultural do "ser jovem" em cidades pequenas? Como os jovens vivenciam, percepcionam e concebem o seu lugar de vivência? O que a cidade oferece aos jovens em termos de espaços públicos de sociabilidade, de práticas de lazer e diversão? Que fatores têm contribuído diretamente para reduzir as condições dos jovens de experienciar e vivenciar a cidade - sobretudo como um espaço público? As demandas dos jovens por espaços públicos destinados ao encontro, ao lazer e à diversão têm sido colocadas na agenda dos governantes, planejadores e urbanistas? Esses sujeitos são ativos na reivindicação por espaços públicos voltados para o lazer e a sociabilidade?

Essas perguntas também se configuram como questões que poderão ser exploradas pelos leitores deste livro, resultado de reflexões e análise de dados de pesquisa sobre a temática das Juventudes. Evidentemente que cada texto faz um tipo de recorte, e dentro dele diferentes elementos constitutivos do que é "ser jovem" (na cidade ou no campo) são ressaltados. São textos que estabelecem interface com diferentes áreas de conhecimento, como a Geografia, a Arquitetura e Urbanismo, a Educação, a Economia, a História, a Antropologia, a Sociologia, a Psicologia e a Saúde.

1 PIRES, Lucineide Mendes. Os jovens na/da cidade: da cultura geográfica ao direito à cidade. In: CAVALCANTI, Lana de Souza; CHAVEIRO, Eguimar Felício; PIRES, Lucineide Mendes (org.). A cidade e seus jovens. Goiânia: Ed. PUC Goiás, 2015, p. 159-184.

PIRES, Lucineide Mendes. Os jovens em busca do direito à cidade: os espaços públicos em questão. In: PAULA, Flávia Maria de Assis; CAVALCANTI, Lana de Souza; PIRES, Lucineide Mendes (org.). Os jovens e suas espacialidades. Goiânia: Espaço Acadêmico, 2016, p. 93-118. 
Os textos aqui reunidos indicam um caminho intelectual. Sustentando-se em diferentes aportes teórico-conceituais, permitem compreender: o jovem na/ da cidade e o jovem camponês/rural; os aspectos da condição juvenil e suas culturas; as formas de realização de sociabilidades juvenis; as juventudes (contemporâneas), seus dilemas e o futuro; os territórios e territorializações juvenis; a relação dos jovens com o mundo, com a escola e com os movimentos de ocupação estudantil; e as representações sociais dos jovens sobre a Educação Física.

Todos os textos que compõem o livro apresentam coerente fundamentação teórica, indispensável para compreender o jovem como um sujeito social concreto, historicamente determinado e espacialmente situado. Jovem esse que possui singularidades e particularidades, vivências e experiências cotidianas específicas, no campo ou na cidade, em face de outros segmentos populacionais; que transforma e é transformado nas relações que ocorrem em um determinado lugar.

Em conjunto, os escritos apresentados neste livro defendem a necessidade de compreender os jovens na sua diferença. São sujeitos que possuem uma historicidade, visões de mundo diferenciadas, escalas de valores, hábitos, costumes e projetos que lhe são próprios. São sujeitos que estão em interação dialética com o meio em que vivem ao longo do tempo, produto de trocas recíprocas que se estabelecem durante toda a vida nas determinações sociais, que vão operar nos processos de internalização dos seus modos de pensar, ser e agir.

As reflexões e análises feitas nos textos colocam-nos diante da impossibilidade de pensar os jovens separados do lugar, do contexto em que estão inseridos, do cotidiano e de suas práticas espaciais. Impõem, assim, a necessidade de reconhecer as regularidades e as singularidades dos jovens, ou seja, de diferenciá-los entre seus pares, de conhecer as desigualdades, bem como fazer distinções. Para tanto, é preciso tomar como elementos de análise os processos de socialização (família, amigos, escola, trabalho...), os diferentes contextos his- 
tóricos (condições econômicas, cidades do interior...), as práticas espaciais (rotineiras e as dos finais de semana), os elementos estéticos e universos simbólicos distintos, estilos de vida e linguagens diversas, formas de interação e comunicação, entre outros aspectos.

Por fim, cabe dizer que o leitor encontrará aqui referências importantes que o ajudarão a refletir, redimensionar saberes e ampliar os estudos e debates acerca da temática das Juventudes.

Boa leitura!

Profa. Dra. Lucineide Mendes Pires Universidade Estadual de Goiás (UEG) Dezembro de 2021. 


\section{APRESENTAÇÃO}

Rafael Ribeiro dos Santos

Mary Anne Vieira Silva

Organizadores

A obra Juventudes nos (entre) lugares: leituras interdisciplinares contemporâneas, é composta por treze artigos, os quais dispõem de diferentes análises sobre a condição juvenil, jovens, juventudes e as territorialidades juvenis, tanto no espaço urbano, quanto no rural. São textos de áreas diversas, interseccionalizadas, de forma interdisciplinar, por conceitos plurais, revelados nas tramas da vida, nas espacialidades brasileiras. A juventude é marcada por distintos fatores que se entrelaçam à constituição histórica da cidade e do campo, agrupando cotidianos multifacetados, de pessoas, sujeitos que constroem e habitam. Os textos apresentados partem de pesquisas realizadas (e em andamento) em contextos que qualificam os espaços urbano e rural, privilegiando determinados grupos com suas trajetórias socioespaciais particulares.

O desafio da obra ligou-se em capturar as leituras que se desprendem de visões estáveis ou aquelas atreladas em identidades fixas e tempos lineares. O espaço por si é dinâmico e volátil, já o tempo social liga-se as temporalidades que fazem e refazem a cada novo cotidiano. Nesse sentido, as juventudes se moldam, projetam, criam e recriam suas trajetórias, caminhos em espaços e tempos diferentes. Sem ressalvas, os capítulos descortinam as complexidades das juventudes nos espaços brasileiros, por meio de leituras que avançam os campos discursivos cristalizados pelos ideários conversadores e binaristas. Essas suscitam as novas leituras para a construção de alteridades a partir dos jovens e de suas singularidades.

No texto de abertura, Juventudes e cidade: uma leitura acerca das práticas espaciais e da condição juvenil, de autoria de Rafael Ribeiro dos Santos e Mary Anne Vieira Silva, os autores realizam algumas reflexões acerca da categoria juventude, e discutem sobre os jovens e as cidades, sobretudo a partir das 
relações que estes sujeitos estabelecem no e com o espaço urbano. Analisam também os jovens a partir das suas representações no meio urbano, partindo, essencialmente, da condição juvenil exercida/vivenciada por eles, os quais se inserem como atores no processo de produção e reprodução desse espaço, além de vivenciarem as desigualdades e tensões promovidas em seu interior.

No capítulo $A$ cidade e as juventudes: socializações, ressignificações e os desafios dos jovens no espaço urbano, de Marco Antônio Oliveira Lima, traz uma discussão que é um recorte e uma adaptação da dissertação de mestrado do autor, intitulada "O corpo sob a perspectiva de jovens skatistas". No texto o autor estabelece uma reflexão sobre a cidade e as juventudes, partindo do princípio do direito à cidade como condição imprescindível aos jovens, os quais se apropriam, vivenciam e ressignificam os seus espaços, dando a eles novos sentidos. O autor ainda aponta que os jovens e os diferentes grupos juvenis visualizam na cidade o potencial de vivenciarem experiências formativas, que vão dar sentido e significado às suas existências. O texto ainda acentua que ser jovem é ter símbolos culturais específicos de sua fase da vida e usar do corpo como uma linguagem tanto física, quanto estética, para se apropriar dos espaços físicos urbanos. Todavia, os jovens ainda necessitam, segundo o autor, de políticas públicas ao bem estar social, ao lazer, ao direito à cidade que se constitua para todos, sem distinções.

Na sequência, Carla Pizzuti Savian, Naomi André Cambará Barbosa e Benhur Pinós da Costa, com o texto Geografia e Juventudes: é de pluralidades que se fala! Os autores apresentam alguns dos resultados de um projeto de pesquisa e de um projeto de extensão, que se articulam a partir de análises sobre as juventudes, suas territorialidades e a luta pela moradia. Nesse capítulo os autores buscam apresentar as pluralidades juvenis nos referidos projetos de pesquisa, principalmente por meio da narrativa destes sujeitos, que ao longo do texto é trazida em diferentes momentos a partir de suas respostas a indagações diversas. Ao analisar essa multiplicidade de informações narradas pelos seus 
pesquisados, os autores afirmam que os jovens apresentam espacialidades e sociabilidades distintas, além de que a condição juvenil verificada relaciona-se não só com as condições socioeconômicas, mas também com os processos políticos e culturais.

Katiele Hundertmarck, em seu texto Corpos midiáticos constituindo as juventudes, apresenta a discussão de como as mídias atuam no processo de construção dos corpos e subjetividades juvenis, sobretudo na tentativa de estabelecer uma padronização de um corpo "universal" e que deve ser alcançado. No entanto, a autora adverte sobre os caminhos utilizados por jovens nesse processo da busca pelo fantasioso "corpo ideal", os quais podem desencadear transtornos alimentares e impactar diretamente na qualidade de vida. Para isso, Katiele parte da análise de uma publicação de revista, na intenção de identificar as pedagogias culturais e promover a reflexão a partir da problematização desta matéria divulgada.

No texto Territórios subjetivos de um coletivo de jovens na periferia de Porto Alegre, Bruna Molina Leal, Rosemarie Gartner Tschiedel e Nair Iracema Silveira dos Santos discutem acerca da construção de territórios subjetivos juvenis, analisando um evento promovido pelo coletivo "Colaí, Movimento de Cultura", que está situado em uma comunidade periférica da cidade de Porto Alegre, Rio Grande do Sul (RS). Conforme o que expõem as autoras, durante a realização da pesquisa foi possível identificar tensões nas estratégias adotadas pelo Colaí, em que de um lado há o modo burocrático atento às ações do poder público em busca de financiamento; e por outro uma maneira particular que promove os encontros, marcados pelo afeto, arte e cultura. Mesmo diante de diferentes situações que o atravessam, o Colaí permanece ativo e promovendo ações no intuito de agregar um número maior de jovens.

Na sequência, Jefferson Dias Andrade de Jesus, Mary Anne Vieira Silva e Rafael Ribeiro dos Santos, com o capítulo, A territorialização juvenil no/do Parque Ambiental Ipiranga em Anápolis (GO), objetivam discutir sobre os processos 
de territorialização ocorridos no Parque Ambiental Ipiranga, situado na cidade de Anápolis, Goiás (GO). Para tanto, os autores se pautaram na aplicação de questionários (em diferentes dias da semana), entrevistas, bem como os registros no diário de campo; esses procedimentos foram destinados aos jovens da faixa etária de 15 a 24 anos, conforme pressupõe a caracterização feita pelo Instituto Brasileiro de Geografia e Estatística (IBGE). Como resultados os autores apontam o parque como importante ponto de encontro e lazer, especialmente para os jovens; destacam que as territorialidades juvenis existentes nesse espaço são marcadas pela fluidez, na medida em que a apropriação deste território é conformado mediante o dia da semana; outro ponto é de como o parque é usado no decorrer da semana, desde a prática de esportes variados até a sua configuração como lugar de encontro entre amigos, casais e familiares.

Luís Paulo Cruz Borges, no texto As juventudes e o futuro: (re)pensando processos educacionais com a escola de hoje, tem como proposta dialogar com o leitor o que é ser jovem? Essa é uma pergunta que se insere como fio condutor ao longo da investigação, a qual foi parte de uma pesquisa de doutoramento realizada pelo pesquisador. Para buscar as suas respostas o autor parte para a pesquisa com alunos do Ensino Médio de uma escola pública do município de Nova Iguaçu, Rio de Janeiro (RJ). Nesse sentido, o objetivo da análise foi o de detalhar como a relação entre juventude e futuro é vivida/sentida pelos/pelas jovens participantes, especialmente no que tange as expectativas e cobranças que são direcionadas a eles. Nesse percurso o autor realizou a imersão no cotidiano desses jovens escolares, desenvolvendo, portanto, uma pesquisa etnográfica, associada à observação participante. Desse modo, ao longo do capítulo, o leitor irá se deparar com relatos feitos pelos alunos, narrativas que auxiliam a compreender melhor como os jovens da pesquisa pensam as questões futuras que os atravessam já no presente, seja pelas cobranças ou pelas "preparações" que são realizadas. 
O capítulo Educação Física escolar pela representação de jovens no Ensino Médio, escrito por Brunna Thais Reis Sales e Cláudia Valente Cavalcante, analisa como os jovens (estudantes do Ensino Médio) pensam uma das medidas da lei $n^{\circ} 13.415$, que trata sobre a Reforma do Ensino Médio, sobre a Educação Física não como componente curricular obrigatório. Portanto, buscou-se, a princípio, compreender as representações sociais da Educação Física escolar na perspectiva dos jovens do Ensino Médio; investigar a relação entre a história e o conceito de Educação Física; entender, diante desse contexto histórico a situação vigente do referido componente curricular escolar; além de apreender a percepção dos jovens sobre a Educação Física. A pesquisa foi desenvolvida a partir de uma revisão bibliográfica e da realização de trabalho de campo, em que foi feita a aplicação de questionários e entrevistas. Desse modo, a discussão apresentada, sobretudo a partir das opiniões dos jovens pesquisados, é o resultado da investigação desenvolvida pelas autoras, tanto teoricamente, quanto diante da análise em campo.

O texto Olhares de jovens egressos do Ensino Médio: reflexões sobre os enlaces na escola, de Bianca Isabel Pederiva e Suzana Feldens Schwertner, faz uma análise a partir dos olhares de egressos do Ensino Médio no que tange a juventude e a escola. O capítulo é parte dos resultados de uma pesquisa em andamento que investiga justamente o olhar do egresso sobre a escola, sobretudo por meio da aplicação de entrevistas com esses sujeitos. Dividido em três seções, o texto busca inicialmente discorrer sobre as relações de amizade entre os jovens que são desenvolvidas no ambiente escolar; em seguida destaca a importância do encontro com o outro como perspectiva para a formação humana, enfatizando principalmente a alteridade; por fim, reflete sobre a construção de espaços de enlace, os quais se originam pela ressignificação de dados locais da escola, tornando-os propícios ao encontro, à partilha entre os estudantes.

Gracielle de Souza Silva e Joana D'arc Bardella Castro, no texto Educação do/no campo e a juventude que o habita, apresentam uma discussão sobre a 
educação do/no campo a partir de um olhar sobre os jovens. Por meio de uma revisão bibliográfica as autoras analisam as características do jovem camponês/ rural brasileiro e quais os aspectos que influenciam para que eles permaneçam ou não no campo; verificam também quais os desafios enfrentados pela educação do/no campo nos dias atuais. Além disso, investigam de que maneira a educação ambiental contribui para a permanência dos jovens nas áreas rurais, sobretudo por meio da prática de manejo sustentável, a agroecologia. Nesse sentido, apontam que o movimento de educação do campo, além de se caracterizar como resistência frente o cenário político, econômico e educacional do país, vem construindo e consolidando bases pedagógicas que enfocam a agroecologia, realizando, portanto, a crítica ao modo de produção convencional. Essa ruptura de paradigmas trabalha na/pela valorização dos saberes dos povos do/ no campo, e para que a sua formação dialogue com uma realidade camponesa, em benefício de um bem coletivo.

Em seguida, o texto Juventude, movimentos sociais e educação: a participação política dos jovens nas ocupações estudantis em Goiás, de Amanda Beatriz Silva de Godoi, Rafael Ribeiro dos Santos e Rita Castorina Gonçalves Gundim Lemes, expõe a ação política dos jovens no movimento das ocupações estudantis que ocorreram no estado de Goiás. Portanto, os autores objetivam compreender como a participação política juvenil nas ações contestatórias referentes à segunda onda de ocupações secundaristas em Goiás foi abordada pela mídia nas páginas de jornais. Nesse sentido, realizam uma discussão teórica-conceitual sobre a juventude e as atividades dos jovens mediante o movimento das ocupações; discutem também sobre os movimentos sociais e a educação. Analisam as matérias jornalísticas de alguns veículos de informação, com o intuito de verificar como as ocupações e as suas motivações políticas foram retratadas na mídia, seja a partir do negacionismo a esses movimentos ou pelo relato fidedigno as ações que eram desenvolvidas. Nesse contexto, os autores avaliam, essencialmente, o caráter formativo dos movimentos sociais, nesse caso o das ocupações dos estudantes secundaristas, e o papel da mídia durante esse perío- 
do marcado pelas lutas de jovens contrários as arbitrariedades e imposições dos governos, sejam a nível estadual ou federal.

No texto, A participação dos jovens por meio da música sertaneja na Folia de Santos Reis em Anápolis, Goiás, de Mirelle Antônia Souza Freitas e Ademir Luiz da Silva, a análise parte da presença dos jovens como sujeitos que vivenciam as folias anapolinas, especialmente a de Santos Reis, e como a música sertaneja, sobretudo através do "sertanejo universitário", contribui para essa experiência e demarcação juvenil ainda mais presente. Nesse sentido, os autores destacam como a música sertaneja moderna se faz presente em meio aos jovens foliões, responsáveis diretos pela manutenção da tradição da Folia de Reis; e também identificam e apresentam algumas das principais músicas ouvidas durante a festividade, analisando as suas letras e como os jovens se veem representados, se reconhecem e experienciam essas músicas durante a folia. Diante desse contexto, verifica-se a presença do novo (sertanejo universitário), alinhado a vivências juvenis distintas e que não se desprendem do clássico (o chamado "sertanejo raiz"), dando outras conotações a tradição (folia), mas conscientes do seu papel durante todo o período festivo.

O livro finaliza com a contribuição de Tereza Caroline Lôbo e João Guilherme da Trindade Curado, através do capítulo Travessias nos (entre)lugares: os caminhos da juventude em tempos pandêmicos, em que analisam as vivências, representações e transições dos jovens no contexto da pandemia que vivemos. A investigação se dá no município de Pirenópolis, antiga Meia Ponte, situado na área central do estado de Goiás. Na busca de um panorama atual das juventudes pirenopolinas (conhecidas pelos autores, não só pela análise em si, mas por residirem e atuarem profissionalmente como professores na cidade), é realizada uma breve discussão acerca da juventude, a fim de compreender melhor essa categoria de análise. Os autores contextualizam também os jovens nos espaços locais, especialmente os festivos de Pirenópolis (cidade marcada pela tradicional Festa do Divino), além disso, analisam como a juventude, pirenopolina ou não, 
tem vivido durante esse período de pandemia, identificando os limites e possibilidades da realização da condição juvenil destes sujeitos.

Consideramos essencial agradecer a todos aqueles que, de maneira direta e/ou indireta, contribuíram para que este livro se tornasse possível e realizável. Agradecemos de modo muito especial, aos autores e autoras que, gentilmente, nos confiaram os seus manuscritos para que assim pudéssemos compor essa obra e publicá-la, marcada por múltiplas reflexões e que partem de diferentes estados, espaços, contextos e vivências do nosso país. Com carinho, os organizadores.

Desejamos a todos e todas uma excelente leitura, que vocês possam realizar uma imersão no mundo dessas juventudes tão plurais, mas que se tornam singulares por suas particularidades, pelo seu modo de ser e agir no espaço e nos lugares.

Primavera fria e chuvosa de 2021. Anápolis, Goiás. 


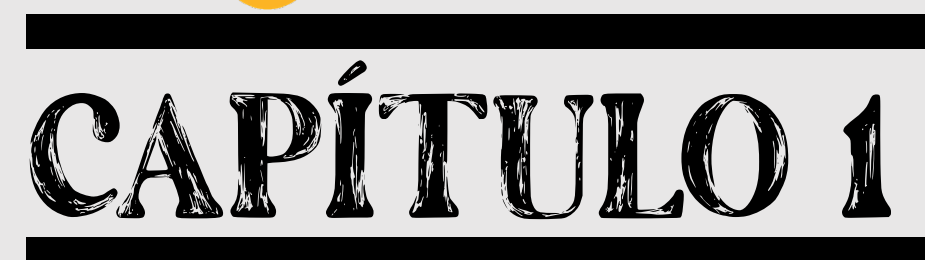

\section{JUVENTUDES E CIDADE: UMA LEITURA ACERCA} DAS PRÁTICAS ESPACIAIS E DA CONDIÇÃO JUVENIL ${ }^{1}$

Rafael Ribeiro dos Santos

Mary Anne Vieira Silva

$1 \quad 0$ artigo é resultado de reflexões voltadas à pesquisa de dissertação do primeiro autor, intitulada "Cotidianos culturais em trânsito: uma análise do processo de (re)territorialização dos jovens migrantes universitários em Anápolis-GO"; e que estão associadas ao projeto de pesquisa "Linguagens urbanas: os jovens, suas espacialidades e redes de sociabilidade em Anápolis-GO", coordenado pela Profa. Dra. Mary Anne Vieira Silva (PPGTECCER/UEG), aprovado junto a Pró-Reitoria de Pesquisa e Pós-Graduação (PrP) da Universidade Estadual de Goiás (UEG). 


\section{INTRODUÇÃO}

A juventude é um tema abordado em pesquisas há algum tempo, sobretudo no âmbito das ciências humanas e sociais, como é o caso da Antropologia, Comunicação Social, Psicologia e Sociologia, como afirmam Cardoso e Turra Neto (2011). A visibilidade do mesmo está associada ao seu contexto histórico, a dimensão social, a qual gera o aparecimento do que se entende como a "condição juvenil", isto é, o modo de ser e agir dos jovens em um contexto espacial e temporal (SOUZA; SANTOS, 2009; CARDOSO; TURRA NETO, 2011; CASSAB, 2011). Para Paula (2013), a Sociologia das Juventudes, frente o fenômeno da virada cultural $^{1}$, passa a se preocupar com as questões ligadas a espacialidade, mais que isso, realiza o uso de conceitos e categorias que são comumente abordados a estudos geográficos, como é o caso do território e suas derivações (territorialização, territorialidade, multiterritorialidade e desterritorialidade) e do lugar.

Embora tanto o tema da juventude quanto o da cidade não sejam, estritamente, ligados ao campo da Geografia, percebe-se que essa ciência tem produzido pesquisas significativas no que tange a aproximação desses assuntos. De acordo com Paula (2013), tratam-se, ainda, de interpretações pontuais, mas essas aumentam paulatinamente, e é no âmbito da Geografia que se percebe, com maior clareza, significativa dedicação em estudar essa relação entre juventude e cidade. $\mathrm{O}$ artigo em questão se apresenta como contribuição aos crescentes estudos. Nossas reflexões são frutos de leituras teóricas multidisciplinares que permitem ampliar as discussões acerca da juventude e da cidade, aberturas de diálogo e aproximações entre os temas.

Desse modo, em um primeiro momento no artigo tratamos de concepções acerca da categoria juventude. Em seguida, realizamos a discussão sobre jovens e cidades, partindo das relações que esses sujeitos estabelecem no e com o espaço urbano. Por fim, analisamos a respeito dos jovens e de suas represen-

1 Período que demarcam "[...] os estudos culturais sobre as culturas juvenis, realizados no final do século XX e início do século XXI [...]” (PAULA, 2013, p. 78). 
tações na dimensão urbana, através da sua condição juvenil, considerando-os como sujeitos que atuam na produção e reprodução desse espaço, além disso, vivenciam as desigualdades e tensões promovidas em seu interior.

\section{REFLEXÕES ACERCA DA JUVENTUDE}

De acordo com Souza e Santos (2009), a juventude ainda se trata de uma categoria de análise que não possui bases conceituais concretas. Ou seja, ela é caracterizada a partir de concepções de autores, por meio de demarcações e particularidades, em que contextos de grupos juvenis específicos são observados. Nesse sentido, para que se possa pensar essa categoria de modo que se aplique a determinada abordagem, é preciso partir de certa demarcação, ou meIhor, deve-se levar em consideração as singularidades e vivências dos sujeitos pesquisados.

Assim, o que se pode afirmar é que a juventude ao longo do tempo assume duas concepções centrais: a primeira a de construção social, histórica e espacial, considerando o processo de autoidentificação feito pelo jovem; a segunda ligada aos fatores biológicos e psicológicos, o que também induz certo reducionismo na forma de se analisar essa categoria tão vasta e densa de sentidos e significados (PAULA, 2013). Contudo, antes de quaisquer inferências, é preciso ter clareza de que a juventude é reflexo da sociedade, é, portanto uma construção social, envolve múltiplas ações e transformações de um povo (CASSAB, 2009; TURRA NETO, 2008).

No decorrer dos anos a juventude foi ganhando novas nuances, diferentes interpretações atribuídas pela sociedade. De acordo com Paula (2013, p. 73)

[...] na década de 1950, a representação social que predominava era a do entendimento da juventude como problemática e transgressora dos padrões sociais, à qual a rebeldia e a delinquência seriam inerentes. Predominou ainda, nesse período, a visão da juventude como uma fase de transição para a vida adulta. Já nas décadas de 1960 e 1970, com o número crescente de movimentos sociais estudantis e de contracultura - que reivindicavam, por exemplo, desde a igualdade entre os sexos e as raças até o fim de ditaduras políticas -, a juventude teve sua imagem vinculada ao poder de contestação, sendo caracterizada como uma ju- 
ventude revolucionária e transformadora (PAIS, 2003; KEHL, 2004; TURRA NETO, 2010) [...]

[...] Contraditoriamente às décadas anteriores, no final dos anos de 1970 e, sobretudo, na década de 1980, a juventude foi rotulada, principalmente pelos meios de comunicação, como consumista e alienada. Isso se deu, entre outros aspectos e fatores, por ela ser, a partir daquele momento, considerada pelo capital como um mercado consumidor em potencial, para o qual foram criados produtos específicos.

A partir das contribuições acima, inferimos que a juventude foi concebida inicialmente, ao longo das décadas do século XX, a partir da perspectiva política, de modo com que esses jovens eram sinônimos de contraculturas instauradas, tidas como sujeitos revolucionários e que propunham e lutavam por transformações sociais. Todavia, em um segundo momento, nas últimas décadas do século $X X$, eles são associados com grupos alienados e com alto poder de consumo, impulsionados pela criação de diferentes produtos voltados especificamente a eles, assumindo, contornos plurais e imprecisos, conforme Cardoso e Turra Neto (2011). Desse momento em diante, foram criadas, por meio dos veículos midiáticos e mercadológicos, as chamadas culturas juvenis, grupos marcados por diferenças no modo de se vestir, agir e se manifestar, sobretudo em relação aos adultos e as suas características.

Dayrell (2003) pondera que a noção de juventude, nessa perspectiva diversa e plural deve ser desassociada de padrões rígidos e entendida como parte de processos mais amplos, em que se considerem as subjetividades dos sujeitos jovens, suas vivências sociais. $O$ autor ainda acrescenta que isso é olhar para a juventude de modo que ela não seja nem um fim pré-estabelecido, ou mesmo uma fase de transição e/ou preparação para a vida adulta, mas sim condição processual de formação do sujeito enquanto ser social. Essa posição de Dayrell (2003) vai ao encontro da concepção de Souza e Santos (2009) ao passo em que os autores apontam que a condição juvenil se insere dentro da experiência social, a qual vai determinar comportamentos individuais e coletivos que dão sentidos às suas práticas espaciais. 
Destarte, a juventude não se limita a segmentação de dada etapa da vida, o que leva a noção de que a vida humana é dividida rigorosamente em etapas bem definidas e que são vivenciadas em determinados períodos. Essa categoria então diz respeito a um "[...] conjunto com o processo ímpar da formação de "agregados sociais", o que implica na análise sobre formas específicas de transição, deslocamento de ações, condutas e expressões de atores sociais juvenis e suas influências na sociedade contemporânea [...]" (SOUZA; SANTOS, 2009, p. 3, grifo dos autores). Diante dessa lógica, Cassab (2007, p. 159) também afirma que a juventude "[...] é, portanto, também uma representação simbólica fabricada pelos grupos sociais [...]". Ou seja, uma representação produzida, tanto pelos grupos sociais, quanto pelos próprios jovens, e que busca traduzir o conjunto de comportamentos, atitudes e aparências a ela atribuídos.

Frente a esse contexto, Paula (2013, p. 77) acrescenta que o jovem passa a ser "[...] influenciado por suas experiências cotidianas, sociais, históricas e espaciais. Além disso, ele é capaz de intervir no mundo em que vive a partir de sua capacidade de percepção e conhecimento, produzindo espacialidades e influenciando outros sujeitos por meio delas". Nesse sentido, torna-se pertinente buscar entender as particularidades associadas ao cotidiano desses jovens, sobretudo no que tange a sua vivência dentro de um contexto espacial. Portanto, na medida em que as cidades se despontam como os grandes centros atuais e que comportam a maior parte da população mundial, tornam-se o lócus de vivências jovens.

O jovem então passa a vivenciar a dimensão urbana, com suas complexidades e contradições. Nesse sentido, fatores que levam o jovem a um sentimento de privação, e de negação de um direito ao uso do espaço em sua totalidade são inerentes a essa espacialidade, movida e dotada de relações hierárquicas de poder. O sujeito jovem, portanto, passa a conviver, por vezes, com um sentimento de não pertencimento àquele espaço, o que o impossibilita de criar elos mais profundos e complexos, estabelecer uma identidade, criar, por meio de suas práticas relacionais, a(s) sua(s) territorialidade(s). 


\section{OS JOVENS E AS CIDADES}

Para Cavalcanti $(2008$, p. 7) "as cidades têm merecido a atenção de arquitetos, historiadores, psicólogos, engenheiros, geógrafos, em diferentes perspectivas". São múltiplas as possibilidades de estudo por parte desses profissionais em relação à cidade, sobretudo ao considerar a cidade como um espaço que é produto das diversas relações sociais que são estabelecidas em seu interior. Em um contexto de produção histórica e social, a cidade, conforme Carlos (2004, p. 15), "[...] pode ser entendida, dialeticamente, enquanto produto, condição e meio para a reprodução das relações sociais, enquanto produtoras da vida humana, no sentido amplo da reprodução da sociedade. Aqui a cidade se reafirma enquanto espaço social [...]".

Desse modo, de acordo com Carlos (2004), a cidade é o espaço efetivo e produzido pelas relações sociais nela existentes, e pela ação dos seus sujeitos e agentes sociais que a produzem. Assim, a cidade está imbricada com as práticas socioespaciais cotidianas, essas últimas produzidas pela ação desse conjunto de sujeitos e os fenômenos que ali existem. Portanto, para Carlos (2004, p. 18)

A vida cotidiana [...] se definiria como uma totalidade apreendida em seus momentos (trabalho, lazer e vida privada) e, nesse sentido, guardaria relações profundas com todas as atividades do humano - em seus conflitos, em suas diferenças. [...]. Nesta direção, o sentido da cidade é aquele conferido pelo uso, isto é, os modos de apropriação do ser humano para a produção de sua vida (e no que isto implica).

Nessa lógica, são as ações que os indivíduos produzem nos espaços da cidade, que conferem vida, a efervescência dos ritmos urbanos. Contudo, é preciso entender que a promoção dessas ações também está associada à classe social que cada um está inserido, pois essa passa a agir como fator determinante e limitador em como os indivíduos usufruem desse mesmo espaço. Essa questão nos leva a discussão apresentada por Lefebvre (2001) no que tange o direito à cidade, o direito do uso do espaço por todas as pessoas que nele habitam. Cavalcanti (2008, p. 83, grifo da autora) expressa que 
Reafirmar o direito à cidade é uma maneira de contraposição à organização dominante da sociedade atual, que quer se autodenominar "globalizada", ressaltando uma tendência de homogeneização de seus espaços. A defesa do direito à cidade para todos os seus habitantes parte do entendimento de que a produção de seu espaço é feita com a participação desses habitantes, obedecendo a suas particularidades e diferenças. Trata-se de defender a necessidade de uma cidade com gestão democrática, que busca conciliar interesses e ações de uma ordem socioeconômica mais geral com os interesses e ações mais imediatos e elementares, nem por isso menos importantes para a vida humana, do cotidiano de seus moradores.

Essa luta pelo direito à cidade vai para além de um desejo das pessoas em usufruírem o espaço urbano ${ }^{1}$ de forma igualitária, perpassa a lógica dos direitos humanos, o direito de cada sujeito exercer a sua cidadania. Dentre os sujeitos, destacam-se os jovens, que constroem a sua condição juvenil a partir dos espaços e contextos de vivências em que estão inseridos, desse modo, a condição social acaba impactando fortemente no modo como esses indivíduos, marcados pela desigualdade, passam a se apropriar da cidade. O cotidiano dos jovens deveria ser assinalado pelas formas como eles utilizam o espaço e do seu tempo, uma vez que a vida cotidiana articula esses dois fatores para que possa existir (SEABRA, 2004), todavia, eles acabam sendo negados de usufruírem desse cotidiano de maneira integral, ou mesmo parcial.

A negação do uso de determinados espaços pelos jovens em função de suas condições econômicas abre caminho para o limite imposto a esses sujeitos em relação às suas práticas de lazer, o que deveria ser um direito fundamental. Afinal,

[...] o lazer, além de ser considerado um espaço importante para o desenvolvimento das relações de sociabilidade entre os jovens, é uma das dimensões mais significativas da vivência juvenil, constitui-se como um espaço menos regulado e disciplinado que o da escola, do trabalho e da

1 "O espaço urbano compreende o lugar da vida movimentada pela prática humana a partir do modo pelo qual o ser humano desenvolve sua relação com as pessoas e com o espaço concreto. É o lugar no qual a vida social encontra-se em constante troca e conflito com as construções, vías de circulação, meios de transporte, telecomunicações, etc. Nele podem-se tecer diversos modos de vida, de idéias, de conceitos, preconceitos, de usos, de apropriação e poder, tanto na relação entre pessoas/pessoas como na relação entre pessoas e o espaço" (SANTOS, 2007, p. 33). 
família, onde eles podem expressar seus desejos, aspirações e projetar outro modo de vida (PAULA; PIRES, 2013, p. 92).

Perante o exposto, cabe sublinhar que o lazer se insere então como um dos pilares na construção de sociabilidades entre os jovens, pois são os momentos em que eles têm a oportunidade de se conhecerem, estabelecer elos, aproximações. Nesse sentido, diante dessas amplas transformações, frutos da urbanização e do processo globalizatório, da chamada "integração do mundo", isso tudo acaba implicando na forma como o jovem passa a se relacionar com a cidade, sobretudo pela ausência de espaços que os levem a uma aproximação mais efetiva, a uma territorialização (TURRA NETO, 2013).

Assim, a cidade se apresenta como um espaço marcado por tensões e por domínios, os quais são exercidos por aqueles que possuem maior controle do capital, o que, consequentemente, desvela as marcas da segregação socioespacial. Embora se tenha uma série de espaços que são considerados públicos nas cidades, esses também estão engendrados na lógica da dominação, em que os sujeitos que se encontram mais distantes dessas áreas não terão condições de usufruí-las. Nesse sentido, os jovens se apresentam como um dos grupos mais prejudicados dentro desse espaço de tensões, especialmente por terem a sua condição juvenil, em alguns casos, negada, ou mesmo cerceada, uma vez que muitos ainda não trabalham e se dedicam somente aos estudos, o que potencializa a falta de acesso a determinados bens e serviços dessas áreas públicas urbanas.

\section{OS JOVENS E A SUA CONDIÇÃO JUVENIL}

De acordo com Dayrell (2007, p. 1106, grifos do autor) a noção de condição juvenil surge

Do latim, conditio refere-se à maneira de ser, à situação de alguém perante a vida, perante a sociedade. Mas, também, se refere às circunstâncias necessárias para que se verifique essa maneira ou tal situação. Assim, existe uma dupla dimensão presente quando falamos em condição juvenil. Refere-se ao modo como uma sociedade constitui e atribui significado a esse momento, ciclo da vida, no contexto de uma dimensão 
histórico-geracional, mas também à sua situação, ou seja, o modo como tal condição é vivida a partir dos diferentes recortes referidos às diferenças sociais - classe, género, etnia etc.

Assim, a condição juvenil diz respeito à forma como a sociedade compõe e dá significado a juventude, em um contexto de vivência a partir das distintas diferenças sociais estabelecidas, em uma dimensão histórica-geracional. Nesse sentido, é possível salientar que a condição juvenil considera tanto os fatores simbólicos, quanto os concretos em que o constructo social da juventude se ancora e desenvolve-se. Além do mais, conforme Dayrell (2007) é preciso situar a análise acerca da condição juvenil no tempo e no espaço, principalmente diante das profundas transformações socioculturais ocorridas nas últimas décadas. Assim, a condição juvenil passa a se manifestar em diferentes espaços, em uma ampla dimensão, no sentido de que haja a promoção de redes de sociabilidade, uma integração entre os jovens.

Para os jovens, essa sociabilidade se constitui como uma forma de comunicação, autonomia, instauração de laços afetivos, de identidade, todavia, há também os conflitos dentro desse mesmo processo que, mesmo em menor número, é preciso que se considerem também tais divergências (DAYRELL, 2007). Para Paula (2013) o tempo e o espaço são dois pontos importantes para que essas sociabilidades ocorram, especialmente quando se trata do espaço urbano que através dessas redes de proximidade os jovens passam a atuar na transformação e produção dele em função das relações afetivas e de dominação que ali ocorrem. É através dessas relações que as territorialidades se dão, embora de forma instável, transitória.

Para Saquet (2010, p. 192)

A territorialidade é o acontecer de todas as atividades cotidianas, seja no espaço do trabalho, do lazer, da igreja, da família, da escola, etc., resultado e determinante do processo de produção de cada território, de cada lugar; é múltipla, e por isso, os territórios também o são, revelando a complexidade social e, ao mesmo tempo, as relações de dominação de indivíduos ou grupos sociais com uma parcela do espaço geográfico, outros indivíduos, objetos e relações. 
Diante dessa concepção, é possível concluir que a territorialidade se apresenta como o desenrolar da vida cotidiana em certo espaço e que se dá de forma diferenciada, o que faz com que os territórios também sejam, em função das relações que ali são desenvolvidas. Outro ponto de destaque, conforme Paula (2013, p. 86) "[...] é o aspecto das múltiplas territorializações e territorialidades que os diferentes sujeitos e atores podem desempenhar, vivenciar e efetivar no espaço". Afinal, diante das relações que os sujeitos, sobretudo os jovens, estabelecem com seus pares e com os espaços, essas territorialidades podem ser múltiplas, mais que isso, os jovens se reterritorializam de maneira rápida, a depender dos vínculos de pertencimento que eles despertam com um ou outro ambiente.

Esse rápido processo de transição dos jovens ${ }^{1}$ pode ser compreendido através de fatores como a prática espacial ${ }^{2}$ desempenhada por eles, que designam suas relações sociais em uma dimensão do espaço e do tempo (LEFEBVRE, 2006); assim como as culturas juvenis que esses estabelecem e que são demarcadas por uma dimensão simbólica, a fim de demarcarem a sua identidade juvenil (DAYRELL, 2007). Essas culturas juvenis são constituídas em um cenário de relações com outros jovens, longe da visão de outros sujeitos, na intenção de demarcarem a sua própria identidade, são demarcadas pela diversidade em que se constituem e visibilizadas através dos corpos e do visual que os designam dentro de certa cultura (DAYRELL, 2007).

1 Sobre essa dinâmica que ocorre entre os jovens, Cavalcanti (2013, p. 80) afirma que esses são "[...] agentes do processo de produção e reprodução do espaço urbano, pois em seu cotidiano fazem parte dos fluxos, dos deslocamentos, da construção de territórios; criam demandas; compõem paisagens; imprimem identidades e dão movimento aos lugares. Essa produção/reprodução se articula a diferentes modos de inserção desses jovens, dependendo de sua condição socioeconômica, do gênero, etnia, raça, opção religiosa, condição sexual, e de sua vinculação aos diversos grupos. Por diferentes modos, buscam constituir seus lugares, em espaços públicos ou privados, na rua, no clube, na praça, nos bares, na escola, imprimindo neles suas marcas, construindo suas identidades (HALL, 1997)".

2 "A prática espacial de uma sociedade secreta seu espaço, ela o põe e o supõe, numa interação dialética: ela o produz lenta e seguramente, dominando-o e dele se apropriando. [...] Ela associa estreitamente, no espaço percebido, a realidade cotidiana (o emprego do tempo) e a realidade urbana (os percursos ,e redes ligando os lugares do trabalho, da vida "privada", dos lazeres)" (LEFEBVRE, 2006, p. 39, grifos do autor). 
Destarte, cabe aqui ressaltar que a condição juvenil, em todas as suas particularidades, se apresenta como uma fase de grande relevância no processo formativo dos sujeitos jovens, principalmente por ser um período de experiências, em que eles possuem o contato com coisas novas, com outros jovens, vivenciando e gozando de suas possibilidades. É um período em que constituem suas identidades, suas redes de sociabilidade, estabelecem suas práticas espaciais em períodos específicos, convivem com os limites e as possibilidades, as tensões e contradições engendradas no contexto da vida urbana.

\section{CONSIDERAÇÕES FINAIS}

Após expor algumas considerações ao longo do texto, as quais versam desde a noção de juventude, às relações dos jovens com a cidade e a realização da sua condição juvenil espacialmente, o que se conclui é que ainda há muito que se explorar. Portanto, o que se expõe aqui não são ideias conclusivas, sobretudo porque essas não se findaram, pelo contrário, são considerações parciais acerca de um tema rico e vasto de possibilidades. Tratar a juventude e sua relação com a dinâmica da cidade requer esforço por parte do pesquisador, mais que isso, atenção aos diferentes pontos, às discussões que se apresentam dentro desse complexo contexto relacional.

A concepção de juventude se apresenta de forma ampla, no sentido de que ainda não é, necessariamente, algo que possui uma dada concreticidade, mas que apresenta fatores subjetivos e que devem ser considerados. Os jovens são um grupo social que no âmbito da cidade, em sua condição juvenil, expressam necessidades, desejos próprios, eles querem vivenciar a sua juventude. Todavia, para isso eles precisam de garantia de seus direitos, de medidas que levem a uma vivência efetiva do espaço. Afinal, devemos entender que a juventude é marcada também por contrastes e conflitos, os quais devem ser compreendidos como elementos constituintes da natureza humana, até para que não reduza essa condição social a perspectivas romantizadas, como algo que não apresenta tensões e divergências. 
A juventude é, antes de tudo, uma condição social, embora seja esse um direito que é negado para boa parte dos jovens. Nesse sentido, é preciso que os gestores do espaço deem maior atenção aos jovens, a fim de que promovam políticas públicas no intuito de que a juventude, a capacidade de uso, o direito à cidade não se restrinja a poucos, para que não seja privilégio de classes, mas direito desses em sua condição de cidadão. Tal medida justifica ainda mais a necessidade de pesquisas sobre a juventude, pois por meio da promoção desses estudos, é possível que seus resultados cheguem aos governantes, promovendo, quem sabe, uma conscientização sobre a situação, um olhar mais atento aos jovens e às suas necessidades espaciais e temporais.

\section{REFERENCIAS}

CARDOSO, Diogo da Silva; TURRA NETO, Nécio. Juventude, cidade e território: esboços de uma Geografia das juventudes. In: SEMINÁRIO DE PESQUISA: JUVENTUDES E CIDADE, 1,. 2011, Juiz de Fora. Anais [...]. Juiz de Fora: Universidade Federal de Juiz de Fora, p. 1-19, 2011. Disponível em: https://www.ufjf. br/nugea/files/2019/09/JUVENTUDE-CIDADE-E-TERRIT\%c3\%93RIO-ESBO\%c3\%87OS-DE-UMA-GEOGRAFIA-DAS-JUVENTUDES.pdf. Acesso em: 13 jul. 2020.

CARLOS, Ana Fani Alessandri. Uma leitura sobre a cidade. Revista Cidades, Presidente Prudente, v. 1, n. 1, p. 11-30, jan./jun., 2004.

CASSAB, Clarice. (Re)Construir utopias: jovem, cidade e política. Tese (Doutorado em Geografia) - Programa de Pós-Graduação em Geografia, Departamento de Geografia, Instituto de Geociências, Universidade Federal Fluminense, Niterói, 2009.

CASSAB, Clarice. Contribuição á construção das categorias jovem e juventude: uma introdução. Locus: revista de História, Juiz de Fora, v. 17, n. 2, p. 145-159, jul./dez., 2011. Disponível em: https://periodicos.ufjf.br/index.php/locus/article/ view/20352. Acesso em: 10 jul. 2020. 
CASSAB, Clarice. O lugar da juventude: espaço-temporalidades da noção de juventude. In: CONGRESSO DE LA ASSOCIACIÓN LATINOAMERICANA DE SOCIOLOGIA, 26,. 2007, Guadalajara. Anais [...]. Guadalajara: AssociaciónLatinoamericana de Sociologia, s./p., 2007. Disponível em: http://cdsa.aacademica. org/000-066/1729.pdf. Acesso em: 10 jul. 2020.

CAVALCANTI, Lana de Souza. A Geografia escolar e a cidade: ensaios sobre o ensino de geografia para a vida urbana cotidiana. 3. ed. São Paulo: Papirus, 2008.

CAVALCANTI, Lana de Souza. Jovens escolares e a cidade: concepções e práticas espaciais urbanas cotidianas. Caderno Prudentino de Geografia, Presidente Prudente, volume especial, n. 35, p. 74-86, set./dez., 2013. Disponível em: http://revista.fct.unesp.br/index.php/cpg/article/view/2171. Acesso em: 12 set. 2019.

DAYRELL, Juarez. A escola "faz" as juventudes? Reflexões em torno da socialização juvenil. Educação e Sociedade, Campinas, v. 28, n. 100, p. 1105-1128, out., 2007. Disponível em: http://www.scielo.br/pdf/es/v28n100/a2228100. Acesso em: 12 set. 2019 .

DAYRELL, Juarez. O jovem como um sujeito social. Revista Brasileira de Educação, Rio de Janeiro, s./v., n. 24, p. 40-52, set./dez., 2003. Disponível em: http:// www.scielo.br/pdf/rbedu/n24/n24a04. Acesso em: 12 set. 2019.

LEFEBVRE, Henri. A produção do espaço. Tradução de Doralice Barros Pereira e Sérgio Martins. S/l, 2006. Disponível em: https://gpect.files.wordpress. com/2014/06/henri_lefebvre-a-produc3a7c3a3o-do-espac3a7o.pdf. Acesso em: 2 nov. 2018.

LEFEBVRE, Henri. O direito à cidade. Tradução de Rubens Eduardo Frias. São Paulo: Centauro, 2001.

PAULA, Flávia Maria de Assis. Jovens migrantes na metrópole de Goiânia: práticas espaciais, (re)territorializações e redes de sociabilidade. Tese (Doutorado em Geografia) - Programa de Pós-Graduação em Geografia, Instituto de Estudos Socioambientais, Universidade Federal de Goiás, Goiânia, 2013. Disponível em: https://repositorio.bc.ufg.br/tede/handle/tde/2917. Acesso em: 12 set. 2019. 
PAULA, Flávia Maria de Assis; PIRES, Lucineide Mendes. Os jovens e a cidade: práticas espaciais, redes de sociabilidade e a constituição de territorialidades. Caderno Prudentino de Geografia, Presidente Prudente, volume especial, n. 35, p. 87-106, set./dez., 2013. Disponível em: http://revista.fct.unesp.br/index. php/cpg/article/view/2262. Acesso em: 12 set. 2019.

SANTOS, Eliete Moreira dos. A produção do espaço urbano e a imagem da cidade pelo migrante jovem. Caminhos da Geografia, Uberlândia, v. 8, n. 24, p. 33-45, dez., 2007. Disponível em: http://www.seer.ufu.br/index.php/caminhosdegeografia/article/view/15548. Acesso em: 15 ago. 2020.

SAQUET, Marcos. Aurélio. Abordagens e concepções de território. São Paulo: Expressão Popular, 2010.

SEABRA, Odette Carvalho de Lima. Territórios do uso: cotidiano e modo de vida. Cidades, São Paulo, v. 1, n. 2, p. 181-206, jul./dez., 2004. Disponível em: http:// revista.fct.unesp.br/index.php/revistacidades/article/view/476. Acesso em: 12 set. 2019.

SOUZA, Antônio Vital Menezes de; SANTOS, Vinícius Silva. Territorialidade e redes de sociabilidades juvenis: lugares, trânsitos e tensões da identidade. In: SEMINÁRIO DE ESTUDOS CULTURAIS, IDENTIDADES E RELAÇÕES INTERÉTNICAS, 2009, São Cristóvão. Anais [...]. São Cristóvão: Universidade Federal de Sergipe, p. 1-9, 2009. Disponível em: https://ri.ufs.br/bitstream/riufs/509/1/ TerritorialidadeSociabilidadeJuvenis.pdf. Acesso em: 13 jul. 2020.

TURRA NETO, Nécio. Geografia cultural, juventudes e ensino de geografia: articulações possíveis. Revista Formação, Presidente Prudente, v. 1, n. 20, p. 38-56, jan./jun., 2013. Disponível em: https://revista.fct.unesp.br/index.php/formacao/article/view/2651/2323. Acesso em: 5 set. 2020.

TURRA NETO, Nécio. Múltiplas trajetórias juvenis em Guarapuava: territórios e redes de sociabilidade. Tese (Doutorado em Geografia) - Programa de Pós-Graduação em Geografia, Faculdade de Ciência e Tecnologia, Universidade Estadual Paulista, Presidente Prudente, 2008. Disponível em: https://repositorio. unesp.br/bitstream/handle/11449/105044/turraneto_n_dr_prud.pdf?sequence=1. Acesso em: 10 set. 2020. 


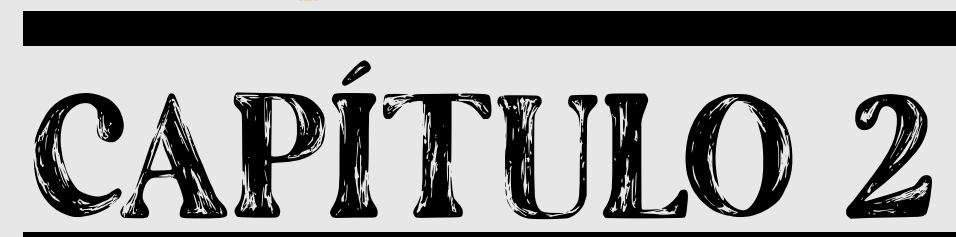

\title{
A CIDADE E AS JUVENTUDES: SOCIALIZAÇÕES, RESSIGNIFICAÇÕES E OS DESAFIOS DOS JOVENS NO ESPAÇO URBANO 1
}

\author{
Marco Antônio Oliveira Lima
}

1 O texto é uma adaptação e recorte da Dissertação "O Corpo sob a Perspectiva de Jovens Skatistas" (LIMA, 2017). 


\section{INTRODUÇÃO}

O direito à cidade é uma condição social e inalienável em toda e qualquer fase da vida. Deste modo, os jovens e os grupos juvenis, assim como indivíduos pertencentes às demais fases geracionais, devem ter amplo acesso à cidade, aos serviços públicos disponíveis e aos diferentes espaços urbanos em que a vida pulsa em forma de cultura, arte, lazer e educação.

No que tange aos jovens, vale mencionar que eles, ao se apropriarem da cidade, são capazes de ressignificar seus espaços dando novos sentidos tanto à própria vida quanto aos lugares que frequentam e materializam as interações específicas de sua fase da vida.

Então, os jovens e os diferentes grupos juvenis aos quais eles se integram veem na cidade infinitas possibilidades de vivenciarem experiências formativas, que dão sentidos e significados específicos às suas existências, que ocorrem em realidade material contraditória e marcada pela divisão de classes sociais.

Ser jovem é ter símbolos culturais específicos de sua fase da vida, utilizar de linguagens corporais e estéticas para interagir e se apropriar dos espaços físicos no meio urbano. Mas, também, ter a clareza de que a ausência de políticas públicas - destinadas ao seu bem estar e ao dos seus semelhantes - impactam o pleno desenvolvimento de suas potencialidades humanas, não unicamente no futuro, mas principalmente no presente.

Acredita-se que os jovens, sobretudo os jovens da classe operária, das periferias urbanas, possuem diante de si desafios políticos, que os conclamam às/aos mobilizações/movimentos sociais para a constituição de sociedade justa, onde o direito à cidade se constitua para toda e qualquer pessoa, seja ela jovem ou não. 


\section{JOVENS NA CIDADE}

Discorrer sobre a cidade não é fácil porque o trânsito, o comércio, os serviços de saúde e lazer que se encontram na mesma só têm relevância se pensados através da inserção humana, pois sua formação é resultante de diferentes interações históricas entre as pessoas.

Carlos (2007, p. 20-21) também é favorável a este olhar e coopera com o debate ao mencionar sobre os aspectos humanos de conceituação do espaço e território. Segundo a autora:

A análise espacial da cidade, no que se refere ao processo de produção, revela a indissociabilidade entre espaço e sociedade, na medida em que as relações sociais se materializam em um território real e concreto, o que significa dizer que, ao produzir sua vida, a sociedade produz/reproduz um espaço através da prática sócio-espacial. A materialização do processo é dada pela concretização das relações sociais produtoras dos lugares, esta é a dimensão da produção/reprodução do espaço, passível de ser vista, percebida, sentida, vivida [...].

Ressalta-se que no presente texto a cidade é entendida como uma criação operada pelos seres humanos, que recebe diferentes formas de intervenções dos sujeitos que a frequentam, a vivenciam e a ressignificam no cotidiano. Recorrendo a Carlos (2007, p. 20, grifo da autora) novamente, encontra-se fundamentação teórica para o argumento apresentado. Diz a autora:

Portanto, deixando de lado postulados e afirmações dogmáticas, podemos tomar como ponto de partida para o desenvolvimento do raciocínio capaz de produzir uma 'leitura geográfica sobre a cidade' a ideia de cidade como construção humana, produto histórico-social, contexto no qual a cidade aparece como trabalho materializado, acumulado ao longo de uma série de gerações, a partir da relação da sociedade com a natureza $[\ldots]$.

Maricato (2013) observa, denomina e classifica a cidade não unicamente pela dimensão do mundo do trabalho. Defende que ela se expande a partir da intervenção do poder público, através de políticas no campo da saúde, iluminação, saneamento básico, pavimentação asfáltica, dentre outras, que são necessárias à qualidade de vida. 
As cidades são o principal local onde se dá a reprodução da força de trabalho. Nem toda melhoria das condições de vida é acessível com meIhores salários ou com melhor distribuição de renda. Boas condições de vida dependem, frequentemente, de políticas públicas urbanas - transporte, moradia, saneamento, educação, saúde, lazer, iluminação pública, coleta de lixo, segurança [...] (2013, p. 33).

Uma vez que a cidade não se limita ao mundo da produção econômica, que no capitalismo se opera pela exploração da burguesia sobre os operários, fato que gera uma hiperespecialização da mão de obra. Ocasionando a cisão do trabalhador sobre o resultado do seu trabalho e a alienação do primeiro sobre o segundo; tal como apresentado por Marx (1985, p.134) ao dizer que "o que caracteriza a divisão do trabalho no interior da sociedade moderna é o fato de ela engendrar as especialidades, as especializações e, com elas, o idiotismo do ofício"; surgem oportunidades de identificação com a cidade. E isto ocorre através dos espaços de educação, lazer, arte e cultura que o meio urbano proporciona aos cidadãos.

A cidade é marcada pela presença de inúmeros indivíduos que circulam em seus vários espaços tendo em vista o alcance de diferentes objetivos. Logo, para captar a cidade e suas mensagens, que são comunicadas no cotidiano, é preciso considerar a pluralidade de grupos - e grupos juvenis - que delimitam diversas linguagens, estando em interação na urbanidade.

Para Harvey (2013, p. 55) há uma dimensão de coletividade na cidade que também passa pelo direito que cada indivíduo possui de acessá-la. O direito à cidade é inalienável. Diz o autor: "O direito à cidade não pode ser concebido simplesmente como um direito individual. Ele demanda um esforço coletivo e a formação de direitos políticos coletivos ao redor de solidariedades sociais [...]".

Devido à condição histórica da cidade, ela não está ilesa às contradições sociais do campo da gestão, resultantes dos conflitos da população contra os diferentes níveis de poder que a administram politicamente. $E$ tais conflitos, em sua radicalidade, são resultantes das lutas das classes sociais em oposição. Para 
tanto, recorre-se a Marx (2008, p. 47, grifo do autor) com vistas a fundamentar o argumento.

[...] Minhas investigações me conduziram ao seguinte resultado: as relações jurídicas, bem como as formas do Estado, não podem ser explicadas por si mesmas, nem pela chamada evolução geral do espírito humano; essas relações têm, ao contrário, suas raízes nas condições materiais de existência, em suas totalidades, condições estas que Hegel, a exemplo dos ingleses e dos franceses do século 18 , compreendia sob o nome de "sociedade civil" [...].

O Brasil adota o capitalismo como modo de produção que orienta seu modelo econômico. Ressalta-se que é também por este paradigma que a gestão pública se materializa nas cidades do território nacional. Todavia, no contemporâneo, o capitalismo predominante é o de perspectiva neoliberal, marcado pelo Estado Mínimo e o discurso de que a ineficiência do setor público poderá ser resolvida com o processo de privatização do mesmo e dos serviços por ele ofertados. A respeito da cidade neoliberal Vainer (2013, p. 69) diz o que se segue:

A cidade neoliberal aprofundou e agudizou os conhecidos problemas que nossas cidades herdaram de quarenta anos de desenvolvimentismo excludente: favelização, informalidade, serviços precários ou inexistentes, desigualdades profundas, degradação ambiental, violência urbana, congestionamento e custos crescentes de um transporte público precário e espaços urbanos segregados [...].

Se nos países do primeiro mundo a substituição do Estado de Bem-estar Social (saúde, moradia, educação, lazer, dentre outros) pela estratégia neoliberal do Estado Mínimo gerou demissões coletivas e perda de direitos - resultantes das lutas históricas dos operários -, no Brasil o processo não se diverge. Dizem Brito e Oliveira (2013, p. 116):

[...] Afinal, do binômio matricial industrialização-urbanização no capitalismo periférico e escravocrata brasileiro não saiu um pacto redistributivo entre capital e trabalho, com integração social pela via dos direitos, tampouco uma reforma urbana que revertesse a secular expropriação e segregação socioespacial [...].

Aqui no Brasil, tem-se visualizado nos meios urbanos uma crescente exclusão econômica e social que posterior à Ditadura Militar foi ampliada pelo 
neoliberalismo, adotada nas políticas encampadas nos anos de 1990, nas administrações públicas do ex-presidente Fernando Henrique Cardoso/FHC. Observou-se ainda que existiram estratégias - políticas públicas - de redução da exclusão econômica e social através dos projetos educacionais, habitacionais, profissionais e de renda básica operacionalizados nas gestões dos ex-presidentes Lula e Dilma.

Entretanto, o caminho em direção à inclusão/participação econômica e social é bem mais amplo, passando por criação de projeto histórico social que se materialize na constituição de modelos cooperativos de sociabilidade e ao invés de - exclusivamente - planos de governo que são desativados à medida que outros políticos e partidos ascendam ao poder.

A partir do momento em que os movimentos sociais tomam as ruas, com suas pautas reivindicatórias, são notórias a insatisfação com o poder público e a necessidade de mudança. De elaboração de projeto histórico que inclua os excluídos, considerando a necessidade da coletividade e de medidas políticas planificadas com vistas à redução dos impactos, dos danos históricos que décadas de desigualdades proporcionaram aos mais pobres. Causando vulnerabilidades sociais se comparados às classes privilegiadas e que detentoras dos meios de produção, assumem também o poder político.

A apropriação da cidade pela ação e luta política dos movimentos sociais, com o objetivo de chamar a atenção para o fato de que as condições reais e materiais de vida chegaram a um nível insustentável - típico das sociedades de classe - apresenta-se como uma das maneiras de se tornar concreta a $11^{\text {a }}$ tese de Marx sobre Feuerbach, que diz o seguinte: "Os filósofos só interpretaram o mundo de diferentes maneiras; do que se trata é de transformá-lo" (MARX, ENGELS, 2001, p. 103).

Inserir-se e transformar o meio urbano é resultante do reconhecimento de que tal meio é particularmente humano e que as mobilizações que se travam em seu interior pretendem ressignificar a vida, adequando-o às particularidades da complexa experiência de existir. Nestes dizeres, é que os movimentos sociais, os 
movimentos juvenis, etc, empunham suas bandeiras e mobilizam-se em busca da concretização das suas pautas e demandas. Isso permite a contemplação de uma cidade menos injusta, haja vista que o acesso à mesma é direito de todo e qualquer indivíduo. Para Souto Maior (2013, p. 154):

[...] o direito social depende da vivência concreta da democracia política para que as pessoas excluídas do sistema econômico ou incluídas numa lógica de exploração possam se organizar para questionar criticamente a realidade, expondo publicamente os seus problemas e reivindicando as soluções necessárias. É assim, por conseguinte, que os movimentos sociais são acolhidos pelo direito de forma a tornar juridicamente válida e, portanto, legítima - a sua manifestação e o seu inconformismo diante da injustiça [...].

Mobilizar com vistas à conquista de melhores condições de vida é uma ação que reverbera no despertar da consciência das pessoas, a partir das contradições e conflitos que se dão na realidade concreta e histórica. Indivíduos conscientes são conhecedores da sua condição de classe e do seu protagonismo social. Fato que contribui para o amadurecimento e posicionamento político frente às demandas societárias do vir a ser, uma vez que o mundo está em movimento e pela ação é passível de mudança. Harvey (2013, p. 48) diz:

[...] Se descobrirmos que nossa vida se tornou muito estressante, alienante, simplesmente desconfortável ou sem motivação, então temos o direito de mudar de rumo e buscar refazê-la segundo outra imagem e através da construção de um tipo de cidade qualitativamente diferente. A questão do tipo de cidade que desejamos é inseparável da questão do tipo de pessoa que desejamos nos tornar. A liberdade de fazer e refazer a nós mesmos e a nossas cidades dessa maneira é, sustento, um dos mais preciosos de todos os direitos humanos.

Ao serem conscientes de que é preciso mudar as cidades para a inclusão social e democrática dos menos favorecidos, os jovens (indivíduos históricos), as juventudes (fase da vida) e os grupos juvenis (coletivos de socialização) também se mobilizam com vistas ao pleno acesso à cidade e aos seus diferentes espaços. Sposito (1993, p. 162) afirma:

Mas cenários diversos de conflitos e de ações coletivas aparecem nos anos 80 e início da década atual, trazendo outros atores, formas de apropriação e uso do espaço urbano, redes de sociabilidade e novas imagens da conflitividade social na cidade. Nesta conjuntura, o tema da juventude 
- em especial dos jovens filhos de trabalhadores - torna-se mais visível, revestido de novas indagações, podendo ser analisado sob vários aspectos.

É perceptível que os jovens das classes trabalhadoras possuem certa visão particular sobre a cidade e tal visão dialoga com as particularidades existenciais de sua fase da vida. No Brasil os movimentos juvenis da periferia apresentam como demarcação histórica os anos de 1980, período da redemocratização política.

A cidade que os jovens pensam não se limita à formação para o mundo do trabalho, ampliando-se para demais oportunidades de teor cultural, artístico e do lazer. Isto se verifica ao identificarem-se as juventudes reunindo-se, inclusive para a organização em coletivos sociais e para a militância política. Para Sposito (1993, p. 172):

[...] Os bandos juvenis levam até a exasperação os enfrentamentos interculturais, as disputas pelos territórios e seu controle sócio-político; eles atestam a multiplicidade irredutível de linguagens e estilos de vida, de estratégias de sobrevivência e de comunicação nas grandes cidades.

Nas experiências culturais, de lazer ou políticas os jovens interagem entre si e com o espaço, no caso aqui em específico a cidade e os diferentes locais que nela são destinados ao convívio social. Dentre estes locais destacam-se praças, quadras esportivas, parques públicos, clubes recreativos, pistas para a prática do skate, dentre outros.

Através de tais interações há a constituição de transformações ambivalentes efetuadas sobre os jovens e o meio onde se interagem. Deste modo, é que as edificações de concreto recebem demais tons, de ordem cultural, e o espaço urbano se ressignifica ante os objetivos dos jovens que dele usufruem.

Para Duarte (2012) os grupos juvenis que interagem com a cidade são capazes de elaborar novas formas de linguagens que estabelecem demais sentidos às suas vidas e também à própria cidade. Deste modo, se na cidade existem múltiplas formas de ser jovem, múltiplas também serão as linguagens resultantes 
das interações entre jovens e cidade. E cada grupo se apropria do meio urbano, que a cidade lhe disponibiliza, a partir dos objetivos partilhados em seu interior coletivo.

\begin{abstract}
Nas cidades, sobretudo nas metrópoles, há diferentes maneiras de ser jovem, num panorama onde se desenvolvem diferentes comportamentos, linguagens e formas de relacionamento juvenis. Os jovens se fazem presentes nos bairros, que são locais de encontro, de busca de liberdade e de lazer e também de afinidades ideológicas e artísticas. Exemplos desses comportamentos são os grafites e as pichações, formas de os jovens deixarem suas marcas, sua identificação territorial e apropriação do espaço, ou maneiras de expressar suas indignações. Buscam apropriar-se dos recursos e dispositivos do espaço urbano por meio de símbolos, territórios, ideologias, referências, modas, objetos, bebidas, comidas, entre outros. O consumo, sob esse ponto de vista, não é só uma forma de alienação, mas é também uma forma de expressão [...] (DUARTE, 2012, p. 90-91).
\end{abstract}

Ao passo em que se dão as interações entre os jovens e a cidade, tem-se a sensação de que o meio urbano se adequa às juventudes e as juventudes ao meio urbano dialeticamente. Pela via deste argumento, a impressão que fica é que mesmo os espaços destinados ao consumo de bens materiais, mercadorias, etc, não se concretizam exclusivamente em alienação, mas também em confronto e enfrentamento. Aqui, o corpo se apropria de roupas, calçados e demais acessórios, se enfeita e os coloca na categoria de símbolos culturais, capazes de demarcar as especificidades de ser jovem e de pertença a determinado grupo juvenil, sendo skatistas, adeptos do Rock and Roll, etc.

Uma vez que a cidade é demarcada com os símbolos geracionais e culturais das juventudes, os seus espaços se reconfiguram em locais para encontros, reuniões e celebrações. Tornam-se verdadeiras referências de resistência para os jovens externalizarem seus sentimentos, subjetividades e linguagens mediante a objetividade que é o corpo. O espaço, quando se torna lugar, concede aos jovens outras visões sobre o que se apresentava como sempre igual no cotidiano. Sobral apud Falconi, Ferreira e Miranda (2007, p. 120-121) conceitua o lugar como: 
[...] um conjunto físico de instituição [...], no qual estão inseridas determinadas práticas, mas pode também estruturar práticas em uma ou outra direção [...]. Cada local encontra-se diferenciado de um modo distinto e a classe será muitas vezes um dos fatores determinantes dessa diferenciação.

Ante ao exposto é como se para além da própria casa dos indivíduos jovens, o meio urbano adquirisse a condição subjetiva e simbólica de lugar. E desta forma, apresentando-se como ambiente que os jovens podem constituir amizades, criar grupos, partilhar linguagens culturais e aprender a conviver coletivamente. Por isto, o meio urbano é lugar de experiências e também de formações. O argumento é reforçado por Cavalcante (2010, p. 93) ao dizer que:

[...] o espaço urbano não é apenas um lugar concreto, mas um lugar em que as relações sociais e seus conflitos sobressaem aos olhos dos que vivem nele. Vários estilos de vida, ideias e usos mesclam-se formando um mosaico de grupos sociais que se diferenciam pelos modos de apropriação do espaço urbano. Os agentes que nele habitam falam de um determinado lugar, vivem de acordo com determinados padrões e estilos de vida localizados no espaço social. São gostos de classe que permeiam os modos de vida. Atribuem-Ihes significados, desejos, sonhos que dão sentido ao espaço habitado. Individualmente ou em grupo, cada qual atribui sentido ao espaço vivido conforme o seu olhar.

$\mathrm{Na}$ cidade, distante dos grandes centros comerciais há demais espaços de interação, aos quais os jovens dão sentindo à própria vida. De um lado têm-se os condomínios horizontais, habitados pela classe no poder, e por outro os bairros da periferia - tais como comunidades e conjuntos habitacionais - que carentes de infraestrutura sanitária, pavimentação asfáltica e áreas de lazer, mostram-se como um desafio à jornada geracional das juventudes.

Ainda que morando em bairros cujas condições de habitação são inapropriadas - ao pensar-se na garantia dos direitos de cada cidadão, apresentados pela Constituição Federal de 1988 - os jovens da periferia apresentam criatividade no tocante a constituir novos significados ao espaço da periferia, marcado transversalmente pelas contradições sociais, que são de classe. Nos seus bairros, ruas, campos constituem-se o que Sposito (1993, p. 169, grifo da autora) denomina de "pedaços". Diz Sposito: 
Nos bairros periféricos, nos grandes conjuntos habitacionais, as formas de lazer institucionalizadas ou públicas são praticamente inexistentes. Parte do tempo livre, entre a escola e o trabalho, é gasta em uma área nas ruas, que se torna o "pedaço" [...].

Há a carência de infraestrutura nas periferias e mediante esta condição os jovens ampliam e dão demais significados e sentidos usuais que ultrapassam aqueles aos quais a rua foi criada. Logo, espaço para o tráfego de motocicletas e automóveis, as ruas tornam-se lugares para os encontros, as socializações, o lazer, a arte, a cultura, a política e a formação das suas condições de jovens em um mundo - ainda - demarcado por classes sociais. Por isso é que ser jovem, fazer parte das juventudes e de determinados grupos juvenis é uma condição para o presente e não exclusivamente para o futuro.

Além das questões referentes às dificuldades, mas, sobretudo, de dar novos sentidos à vida na periferia, estes jovens também precisam enfrentar, em seu cotidiano, questões referentes aos preconceitos e julgamentos em relação à sua condição geracional de jovens. Contudo, soma-se a isso a questão de serem jovens periféricos. Sposito (1993, p. 175, grifo da autora) afirma que:

\footnotetext{
Em bairros caracterizados pelos altos índices de violência, os jovens integrantes dos grupos, que estão nos pedaços, nas esquinas das ruas, são "confundidos" com marginais e, portanto, submetidos à violência policial ou de justiceiros, cuja intervenção às vezes é solicitada por moradores ou comerciantes do bairro.
}

Os jovens da periferia, diante desse contexto e inconformados com as péssimas condições de vida a que o poder público os tem submetido historicamente, procuram se articular politicamente com vistas a garantirem que suas vozes sejam ouvidas e suas demandas atendidas. Em meio a tais contradições de ordem da infraestrutura, estes jovens conseguem vislumbrar inúmeras possibilidades e no caos, no conflito criar espaços de debates, discussões e formação política. É quando o pedaço se reconfigura em posse. Sobre a posse Sposito (1993, p. 170, grifo da autora) diz: "muitas vezes o 'pedaço' no bairro pode ganhar a feição de um território, que exprime uma intervenção mais ampla e coletiva, mediante a formação das posses [...]". 
Nota-se que as reuniões juvenis nas posses são marcadas e permeadas pelos discursos políticos engajados, cuja coletividade é um dos alvos a serem alcançados. E a partir da organização coletiva se reconhecem na sua classe e se solidarizam com os desafios a enfrentar, sendo a luta contra a violência, o preconceito, etc. A respeito da experiência política nas posses Sposito (1993, p. 171) explana: "[...] as ações políticas estariam mais próximas daquelas práticas típicas do movimento negro, mediante a participação em manifestações políticas mais amplas como passeatas, organização de cursos e debates".

\section{CONSIDERAÇÕES FINAIS}

Nos processos de relações entre os jovens com seus pares, em interações entre si e em meio à cidade e aos seus espaços urbanos, foi possível identificar amplas relações de socialização que dão novos sentidos às vidas dos jovens bem como ao lugar onde os encontros, as conversas, os diálogos e as sociabilidades se materializam.

Deste modo, os jovens e as juventudes se apropriam da cidade - das suas praças, quadras poliesportivas, parques temáticos e ambientais, ruas, avenidas, centros e galerias comerciais, etc - lançando sobre ela as particularidades culturais, simbólicas, geracionais, éticas e estéticas típicas da sua fase da vida, mas que muda de um contexto para outro.

Logo, os espaços urbanos criados com determinados fins são ressignificados, recebem outras formas e propostas de uso, vivências e experiências a partir das apropriações de múltiplos matizes, efetuadas pelos jovens e seus grupos juvenis. Ficando visível, que os espaços de concreto estão aptos a receberem outras formas de uso, para além das formas primárias para as quais foram criados.

Por esta via, os jovens são capazes de imprimir sobre a cidade suas próprias linguagens, específicas dos grupos juvenis que formam suas identidades e que são relevantes em seus processos históricos de acesso aos meios urbanos, direito inalienável, seja para a cultura, a arte, o lazer e a prática política. 
Contudo, ressalta-se que os jovens elaboram e reelaboram suas vidas em uma realidade material, contraditória e marcada pelas lutas de classes sociais opostas e em conflito histórico, pela tomada do poder e concretização de seus projetos de sociedade e mundo.

Dentre os diferentes jovens que vivenciam cotidianamente os desafios de não terem seus direitos sociais atendidos em sua plenitude, estão aqueles que vivem nos bairros periféricos das cidades e pertencentes às classes sociais operárias ou desfavorecidas economicamente.

Assim, estes jovens da periferia, além dos desafios geracionais de sua fase da vida, enfrentam também os desafios oriundos do demarcador classe, o que exige dos mesmos ampla articulação e organização política engajada, pautada na coletividade, com vistas à luta por condições concretas de vida. Onde suas necessidades de educação, alimentação, transporte, segurança, lazer, formação para o mundo do trabalho, possam ser atendidas.

Ante ao que foi mencionado percebeu-se que o processo de organização política dos jovens, dos grupos juvenis, dos bairros das periferias urbanas segue outra perspectiva mística. Entendendo-se a palavra mística como sinônimo que expressa e faz referência às dinâmicas internas, que se concretizam nos acordos, nos combinados, nos ritos, nos gestos corporais, nos símbolos culturais, nas linguagens específicas, nos contratos informais, etc.

Permitindo-lhes dialogar, construir, apresentar, aceitar, refutar, propostas e estratégias de intervenção, mobilização e manifesto na realidade material e amplamente contraditória. Marcada pela divisão, luta e embate das classes sociais em tensão, oposição e conflito. Cujos desafios se apresentam na concreticidade das demandas de infraestrutura - sanitária, de pavimentação asfáltica, de habitação, de transporte público, de lazer, de educação, de iluminação pública, de segurança pública, de arte e cultura, dentre outros - que seus bairros apresentam. Bairros estes que historicamente e frequentemente são deixados à margem pelas políticas públicas urbanas. 
É nesta perspectiva, que serem jovens (indivíduos históricos), fazerem parte das juventudes (fase da vida), pertencerem a determinados grupos juvenis (coletivos que apresentam interesses éticos, estéticos e políticos em comum), frequentarem os lugares, os pedaços e as posses, que os jovens das periferias urbanas dão novos sentidos e significados - culturais, simbólicos e políticos - à própria existência. Experiências que Ihes permitem encontrar o seu lugar geracional e de classe em um mundo turbulento, mas com possibilidades do devir.

\section{REFERÊNCIAS}

BRITO, F.; OLIVEIRA, P. R. de. Territórios transversais. In.: MARICATO, E. et. al. . Cidades Rebeldes: Passe livre e as manifestações que tomaram as ruas do Brasil. $1^{a}$ ed. São Paulo: Boitempo: Carta Maior, 2013. p. 115-123. Versão digital. Disponível em: https://ujceara.files.wordpress.com/2014/01/cidadesrebeldes-passelivreeasmanifestac3a7c3b5esquetomaramasruasdobrasil.pdf. Acesso em: 30 mar. 2017. p. 115-123.

CARLOS, A. F. A. O Espaço Urbano: Novos Escritos sobre a Cidade. São Paulo: FFLCH, 2007. Versão digital. Disponível em: http://gesp.fflch.usp.br/sites/gesp. fflch.usp.br/files/Espaco_urbano.pdf. Acesso em 15 mai. 2017.

CAVALCANTE, C. V. Jovens e estratégias educativas de apropriação dos espaços urbano e virtual. 2010. 134 f. Dissertação (Mestrado em Educação) Pontifícia Universidade Católica de Goiás, Goiânia, 2010. Disponível em: http:// tede2.pucgoias.edu.br:8080/handle/tede/1260. Acesso em: 07 fev. 2017.

DUARTE, A. J. Jovens urbanos na periferia de Goiânia: espaços formativos e mediações escolares. Tese (Doutorado em Educação) - Universidade Federal de Goiás, Faculdade de Educação, Goiânia, 2012. Disponível em: https://repositorio.bc.ufg.br/tede/handle/tde/1129. Acesso em: 07 fev. 2017.

FALCONI, A. V.; FERREIRA, D. L.; MIRANDA, R., D. Lazer e sociabilidade juvenil na cidade de Sobral-CE. In.: Revista da Casa de Geografia de Sobral, Sobral, v. 8/9, n.1, 2006/2007. p. 111-122. Disponível em: http://www.uvanet.br/rcgs/index.php/RCGS/article/view/94. Acesso em: 25 out. 2016. 
HARVEY, D. A liberdade da cidade. In.: MARICATO, E. et. al. . Cidades Rebeldes: Passe livre e as manifestações que tomaram as ruas do Brasil. $1^{\text {a }}$ ed. São Paulo: Boitempo: Carta Maior, 2013. p. 47-61. Versão digital. Disponível em: https://ujceara.files.wordpress.com/2014/01/cidadesrebeldes-passelivreeasmanifestac3a7c3b5esquetomaramasruasdobrasil.pdf. Acesso em: 30 mar. 2017. p. 47- 61.

MARICATO, E. É a questão urbana, estúpido! In.: MARICATO, E. et. al. . Cidades Rebeldes: Passe livre e as manifestações que tomaram as ruas do Brasil. $1^{\text {a }}$ ed. São Paulo: Boitempo: Carta Maior, 2013. p. 32-46. Versão digital. Disponível em: https://ujceara.files.wordpress.com/2014/01/cidadesrebeldes-passelivreeasmanifestac3a7c3b5esquetomaramasruasdobrasil.pdf. Acesso em: 30 mar. 2017.

MARX, K. A miséria da filosofia. São Paulo: Global, 1985. Versão digitalizada. Disponível em: http://ciml.250x.com/archive/marx_engels/portuguese/marx_miseria-da-filosofia.pdf. Acesso em: 01 abr. 2017.

MARX, K. Prefácio. In.: MARX, K. Contribuição à crítica da economia política. $2^{a}$ ed. São Paulo: Expressão Popular, 2008. p. 45-50. Versão digitalizada. Disponível em: http://petdireito.ufsc.br/wp-content/uploads/2013/06/MARX-Karl.-Contribui\%C3\%A7\%C3\%A3o-\%C3\%A0-cr\%C3\%ADtica-da-economia-pol\%C3\%ADtica.pdf. Acesso em: 01 abr. 2017.

MARX, K; ENGELS, F. A ideologia alemã. São Paulo: Martins Fontes, 2001. Versão digitalizada. Disponível em: http://www.usp.br/cje/anexos/pierre/aideologiaalema_karlmarx_e_engels.pdf. Acesso em: 13 mai. 2015.

SOUTO MAIOR, J. L. A vez do direito social e da descriminalização dos movimentos sociais. In.: MARICATO, E. et. al. . Cidades Rebeldes: Passe livre e as manifestações que tomaram as ruas do Brasil. $1^{\text {a }}$ ed. São Paulo: Boitempo: Carta Maior, 2013. p. 147-158.Versão digital. Disponível em: https://ujceara.files.wordpress.com/2014/01/cidadesrebeldes-passelivreeasmanifestac3a7c3b5esquetomaramasruasdobrasil.pdf. Acesso em: 30 mar. 2017.

SPOSITO, M. P. A sociabilidade juvenil e a rua: novos conflitos e ação coletiva na cidade. In.: Tempo Social; Rev. Sociol. USP, S. Paulo, 5(1-2), 1993 (editado em nov. 1994). p. 161-178 Disponível em: http://www.scielo.br/pdf/ts/v5n1-2/01032070-ts-05-02-0161.pdf. Acesso em: 24 out. 2016.

VAINER, C. Quando a cidade vai às ruas. In.: MARICATO, E. et. al. . Cidades Rebeldes: Passe livre e as manifestações que tomaram as ruas do Brasil. $1^{\text {a }}$ ed. São Paulo: Boitempo: Carta Maior, 2013. p. 62-72. Versão digital. Disponível em: https://ujceara.files.wordpress.com/2014/01/cidadesrebeldes-passelivreeasmanifestac3a7c3b5esquetomaramasruasdobrasil.pdf. Acesso em: 30 mar. 2017. 
dol 10.48209/978-65-JUVEN-40-3

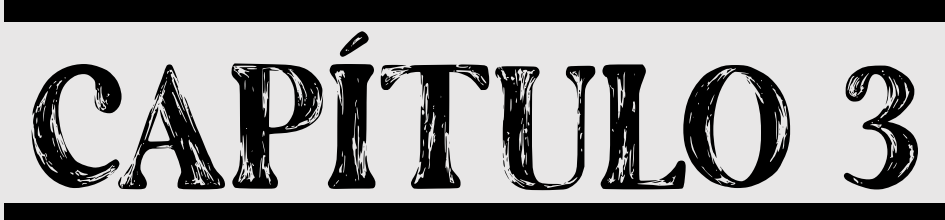

\title{
GEOGRAFIA E
} JUVENTUDES: É DE PLURALIDADES QUE SE FALA!

\author{
Carla Pizzuti Savian \\ Naomi André Cambará Barbosa \\ Benhur Pinós da Costa
}




\section{INTRODUÇÃO}

Existem diversas tentativas de definir-se o que é ser jovem e/ou a juventude, sendo para alguns uma categoria geracional, um momento de vida considerado transitório, por outros preparatório para a vida adulta (ABRAMO, 1997). Somado às tentativas de definição, existem os diferentes contextos em que a juventude se desdobra: seria a juventude uma só, como uma identidade social genérica, pela qual todos e todas são assumidos/as em um dado período da vida?

Ser jovem é ser como tal em todos os espaços cotidianos? De acordo com Gamalho e Heidrich (2012), pesquisadores da geografia, as pessoas vivenciam situações diferentes de tempo e de espaço devido aos contextos sociais, econômicos, políticos, culturais e identitários. Partindo desse fato, a palavra juventude, assim como ser e estar jovem, poderia ser pensada no plural, ou seja, a juventude apresenta uma pluralidade de formas de viver e experienciar o espaço. São tantas as juventudes e os espaços e tempos de suas experiências cotidianas quantos os diferentes marcadores socioespaciais que representam e são representados pelos (as) jovens (TURRA NETO, 2019).

Por esse ângulo, há ainda outra questão: os espaços são ocupados por diferentes pessoas por motivos além das suas vontades (não é apenas sobre o querer ocupar um espaço), mas também por questões de possibilidades e das tentativas de estabelecerem projetos de engajamento social? Sabemos que a juventude tanto implica uma identidade de limitações das possibilidades de inserção no mundo adulto, como lógica hegemônica das relações socioespaciais normalizadas.

Por outro lado, contraditoriamente, também são os novos enquadramentos quanto à formação de espaços de sociabilidades tipicamente de jovens, pelas quais estabelecem suas apropriações mediadas pelas convivências identitárias e apresentações diferenciadas de seus corpos. Mesmo assim, são pelos processos socioespaciais mediados pelos adultos que os (as) jovens são "separados" 
pelas possibilidades de se estabelecerem efetivamente em determinados lugares de convívio socioespacial juvenil.

Os trabalhos de Nola Gamalho (2020) apresentam que espaços pagos são dificilmente acessados por jovens das periferias urbanas pobres, mesmo tais espaços sendo divulgados como elementares para as experiências sociais juvenis genéricas. Isso gera contradições entre as vontades de viver situações sociais que representam a juventude (socialmente ser jovem significa se relacionar de determinadas formas em espaços típicos para estas relações) e impossibilidades efetivas de ser jovem por não conseguir estar e conviver em determinados espaços de sociabilidade. As experiências juvenis, então, são contradições inerentes ao que se espera em ser e estar jovem e as possibilidades socioespaciais em que jovens possam efetivamente experienciar pela cidade, assim como as condições dos seus afazeres cotidianos.

É interessante, dessa forma, pensar como as experiências espaciais juvenis são diferentes e plurais em relação a quem são os jovens em consideração aos seus diferentes marcadores sociais e como esta pluralidade juvenil ora é restringida em vivenciar os espaços/mundos dos adultos, mas também outros espaços conhecidos tipicamente como juvenis.

Por entre negações diversas, táticas juvenis são estabelecidas para que se possa efetivamente instituir formas de sociabilidade em que diferentes jovens se representam. Nesse contexto, o projeto edital 2018 Universal CNPQ intitulado "Juventudes e Múltiplas Territorialidades: diferenças socioculturais em contextos de cidades médias e metrópoles brasileiras", desenvolve diversas pesquisas e atividades de extensão dedicadas ao estudo das espacialidades juvenis, isso é, das experiências e formas de vivenciar o espaço dos jovens nas cidades de Ponta Grossa - PR, Rio de Janeiro - RJ, Porto Alegre - RS e Presidente Prudente - PR e Santa Maria - RS.

Nessa perspectiva, o presente trabalho é um recorte de dois projetos vinculados a esse edital Universal CNPQ, sendo um de extensão intitulado "Educação e Ação no Espaço Social: articulações entre territorialidades juvenis, trabalho 
escolar e as políticas do movimento da luta pela moradia no bairro Nova Santa Marta em Santa Maria/RS" e outro de pesquisa, denominado "Representações do Espaço, Juventudes e Múltiplas Territorialidades: o caso dos jovens moradores do bairro Nova Santa Marta em Santa Maria/RS", realizados no decorrer do ano de 2020.

Acerca de questões metodológicas, a pesquisa e a extensão ocorreram com base em nuances de três metodologias, sendo elas a pesquisa-ação (THIOLLENT, 2006), as geografias narrativas (LINDÓN, 2008) e a constituição de grupos focais (DUARTE, 2007). Como recorte de pesquisa, abordaram-se as sociabilidades de jovens moradoras do bairro Nova Santa Marta em Santa Maria, Rio Grande do Sul, e de estudantes universitários da UFSM, buscando entender e tornar visível as espacialidades de diferentes sujeitos jovens na cidade de Santa Maria-RS, enfocando suas experiências com a cidade, com a identidade juvenil e como estabelecem seus círculos espaciais de amizade e afetividade.

Conforme já mencionado, o presente texto é um recorte dos projetos, posto isso, terá foco em discutir questões como: "O que é ser jovem?", "Como entendem a condição juvenil?" e "Quando um jovem é efetivamente jovem?”, sempre atentando os diferentes contextos e realidades juvenis. Iremos apresentar os resultados oriundos do segundo grupo, ou seja, dos jovens universitários, com o qual surgiu e foi realizada essa discussão.

Por fim, percebeu-se que a conceituação da juventude é complexa, havendo muitas interpretações. Através de narrativas iremos mostrar que a vivência juvenil varia de acordo com o contexto, com as possibilidades em se experienciar mesmo um conjunto de atividades tidas socialmente como juvenis.

\section{METODOLOGIA}

Acerca das questões metodológicas, o projeto necessitou passar por adaptações devido ao início da pandemia de COVID-19, visto que foi realizado no ano de 2020. Em um contexto de pesquisa a ser desenvolvida de forma remota - através apenas do meio online -, foram utilizadas nuances de três metodolo- 
gias, sendo elas a pesquisa-ação, a construção de grupos focais e a geografia narrativa.

A metodologia de pesquisa-ação, de acordo com Thiollent (2017), pode ser usada tanto na pesquisa quanto na extensão - o momento de produção e também o de difusão do conhecimento. Além disso, é uma metodologia participativa na qual pesquisadores, pesquisados e demais grupos ou pessoas envolvidos com uma determinada demanda constroem as atividades e ações em conjunto.

Um grupo focal é, em resumo, uma entrevista que acontece em grupo, havendo um debate sobre um tópico em específico (DUARTE, 2007). A ideia é que, através do diálogo em grupo, sejam coletados dados e resultados. Mas vale ressaltar que não se trata de uma entrevista grupal calcada em um entrevistador ou entrevistadora que espera uma resposta, mas sim uma interação em grupo que dialoga e apresenta seus pontos de vista de forma mais informal.

A geografia narrativa, de acordo com Lindón (2008), se debruça sobre os desafios de compreender a vivência espacial do outro (outras pessoas pesquisadas) como um projeto de alterar o próprio olhar interpretativo sobre quem são tais pessoas, seus cotidianos e a instituição de suas espacialidades. Por ser uma metodologia qualitativa, se preocupa com os significados que os sujeitos atribuem, no caso da geografia, ao espaço - a experiência espacial (LINDÓN, 2008).

Diante do exposto, conseguiu-se organizar dois grupos focais, porém, iremos apresentar nesta escrita as atividades realizadas com apenas um dos grupos, o grupo composto por jovens universitários. O grupo foi constituído através do contato com alunos moradores da casa do estudante universitário da UFSM e colegas do curso de Geografia da mesma universidade. Porém, além da Geografia participaram alunos de outros cursos, tais como Medicina Veterinária, Engenharia Civil e Pedagogia.

As discussões foram realizadas através do aplicativo Whatsapp e neste texto iremos fazer mais um recorte de resultados sobre uma das temáticas que foram discutidas, durante o mês de outubro de 2020: "A Condição Juvenil". A 
temática foi desenvolvida através de alguns questionamentos norteadores, tais como: Existe um significado único compartilhado socialmente que define juventude? Quais os atributos reconhecidos por todos que definem juventude? Você consegue ser jovem efetivamente?

\section{DISCUSSÃO TEÓRICA}

Como foi possível perceber na introdução, esse texto é vinculado a um processo de realização de pesquisa e extensão que abordou as espacialidades e vivências juvenis na cidade de Santa Maria - RS. Nessa perspectiva, apresenta-se a seguir uma discussão teórica visando discutir sobre o que é ser jovem; a interseccionalidade como ferramenta para pensar a juventude; e a relação entre jovens e a cidade.

\section{A condição Juvenil - o que é ser jovem?}

O entendimento do que é ser jovem é muito complexo, existem muitas questões que são colocadas em pauta, inclusive para quem vivencia a juventude. É necessário compreender que esse conceito é algo que é considerado abstrato e muito amplo para ser explorado e abordado. Segundo Cardoso e Turra Neto (2011, p. 5) "a ampliação e a pluralização das formas de expressão juvenil fizeram emergir uma preocupação com o contexto sócio-espacial e histórico, ao mesmo tempo em que apontaram a dificuldade em construir noções gerais.". Isso quer dizer que ser jovem é conjuntural e tem uma perspectiva de historicidade, que indica um conjunto de atributos socialmente construídos sobre determinadas etapas da vida, assim como é localizáveis no tempo (das experiências diárias diferenciadas) e no espaço (cotidiano dos processos de socialização e das informalidades das sociabilidades) de uma determinada atualidade.

No mesmo texto, os autores enfatizam o sintoma epistemológico, que atingiu as ciências humanas nas últimas décadas, denominada como "virada espacial". Este sintoma aponta para a ampliação de trabalhos que versam sobre como o espaço é categoria importante e fundamental para a análise de fenômenos que não eram considerados espaciais, como os estudos sociológicos e antropoló- 
gicos sobre as juventudes. Neste sentido, o desafio é ainda instituir os estudos disciplinares da Geografia neste contexto de "virada espacial" que adentra outras ciências sociais, principalmente sobre a relação das diferentes identidades dos sujeitos sociais e de como são e instituem espacialidades.

Em relação aos estudos sobre juventudes, os espaços de suas experiências são atravessados por relações entre lugares, entre global e local e de instituição de diferentes territórios e territorialidades. A virada espacial fez entender o fenômeno juvenil além de uma etapa genérica da vida, em processo de se tornar adulto, mas como uma multiplicidade de contradições sobre suas atividades, suas sociabilidades, suas capacidades de se entenderem e representarem efetivamente como jovens e inerentes às diferenças construídas em seus projetos de autenticidade.

Juventude é mais que um intervalo numérico geracional e se torna necessário pensar a formação cidadã e de auto-descoberta pelos quais muitos jovens passam na suposta etapa de vida juvenil. Como muitos alunos disseram durante a pesquisa, a juventude perpassa por muitas problemáticas que são inerentes as construções das identidades de ser jovem e transitar para a vida adulta, sempre em processos de diferenciação e busca de autenticidade, mas, contraditoriamente, de engajamento social e igualdade. Por outro lado, também existem contradições intimas sobre ser considerado socialmente como jovem e, efetivamente, sentir-se jovem, em relação às reflexões sobre como cada jovem "leva" a sua vida em comparação às representações compartilhadas e comunicadas sobre ser jovem na sociedade atual.

Durante as entrevistas realizadas, principalmente relacionadas às sociabilidades dos mesmos, percebeu-se que muitos sequer sentiam-se jovens, pois há uma imposição sobre o que é realmente ser jovem e que contrasta sobre muitas demandas sobre a iminência da vida adulta e todos os compromissos que devem assumir para que no futuro alcancem um sucesso profissional e de qualidade de vida adequada. Em relação a tais fluxos contraditórios, desestabilizadores sobre o que são em si, os lugares de sociabilidades juvenis emergem como espaços 
nos quais os sentidos se aguçam para além dos compromissos e as demandas diárias que os/as colocam sempre em contraposição consigo mesmos enquanto jovens que buscam um futuro adulto adequado socialmente.

Os lugares de convivência juvenil apresentam-se como uma rebeldia momentânea às demandas de formarem-se para a vida adulta: é um espaço-tempo de uma situação de curta duração em que todos os compromissos dos adultos, destinados aos jovens como metas de formação, são transgredidos. Os espaços diversos de sociabilidade juvenis na cidade servem como refúgio para conseguirem transgredir as demandas das suas metas de formação como adultos, contudo, diferentemente dos localismos exclusivistas, tal ancoragem identitária e territorial pode ser construída em íntima relação com o global, através das novas tecnologias da informação e comunicação.

\section{Refletindo sobre juventude através da lupa interseccional}

Nesse tópico do texto apresenta-se a teoria da interseccionalidade - do feminismo interseccional -, como ferramenta que pode ser utilizada para pensar a juventude. Para Mayorga (2019, p.134), o feminismo "pretende ser um pensamento crítico da sociedade e, em sua teoria e prática, busca desnaturalizar as compreensões sobre as relações de gênero". Essa desnaturalização é necessária quando se pensa na juventude, visto que as experiências juvenis são construções que ganham significações dadas pelos outros: significações que possuem como consequência um entendimento de que os jovens são sujeitos incompletos e que serão completos ao atingir a vida adulta.

Somente em um futuro como adulto que os/as jovens serão vistos como sujeitos de direito. Isso quer dizer que existe uma lacuna em relação às reais capacidades de engajamento social formal dos/as jovens nos campos institucionais do direito, da política, da economia e da cultura. Quando se pensa a juventude de forma interseccional, as lacunas sobre o reconhecimento da pessoa jovem, perante diferentes contextos de relações e instituições sociais, ainda poderá ser mais precário. $O$ conceito de interseccionalidade tem origem do feminismo negro e pode ser pensado com base em Crenshaw (2002) e Collins (2017) como uma 
ferramenta metodológica e teórica que possibilita visualizar a inseparabilidade que há entre eixos de subordinação, isto é, entre os sistemas de discriminação, dentre eles o racismo, o machismo, preconceito de classe, a misoginia, a lgbtfobia, a origem nacional/regional, entre outros. A interseccionalidade, como conceito, permite perceber articulações existentes entre discriminações - a vida de uma pessoa é perpassada por mais de uma forma de discriminação. Diferentes categorias de opressão inter-relacionam-se em múltiplos níveis e de forma simultânea.

Kimberlé Crenshaw (2002) traz que, por exemplo, mulheres vivenciam o sexismo de forma diferenciada, principalmente quando somadas a outros eixos de subordinação. Esclarecendo, a teoria apresentada não entende que um eixo de discriminação é pior que o outro, pois não há a intenção de apresentar uma hierarquização, mas sim "dar conta da interação entre essas múltiplas formas de opressão, sem, contudo, hierarquizá-las" (ROCHA, 2019, p.153). Sendo o conceito de interseccionalidade uma ferramenta metodológica, é possível utilizá-lo para pensar variadas questões como, por exemplo, a condição juvenil do(a) jovem que trabalha para ajudar em casa e que acaba por vivenciar a juventude de forma diferente do jovem que não realiza tal ato.

E como pode-se usar a teoria da interseccionalidade para pensar "o que é ser jovem"? As vidas das pessoas, sejam elas jovens ou não, são carregadas de um contexto de história de vida. Cada jovem vivencia a juventude de forma diferente do outro(a) e possui essa juventude perpassada por diferentes eixos de discriminação. Por exemplo, a juventude de uma jovem mãe é diferente da juventude de uma jovem que não tem filhos.

A juventude de uma (um) jovem que precisa trabalhar ao mesmo tempo em que estuda é diferente da juventude de uma (um) jovem que consegue participar da escola e/ou da universidade sem precisar trabalhar. A juventude de uma (um) jovem negra (o) é diferente da juventude de uma (um) jovem branca (o), isso porque a juventude do (a) negro (a) é perpassada pelo racismo, enquanto que do (a) branco (a) não. Com isso, pretende-se afirmar que a juventude vai além de 
ser um momento transitório e/ou preparatório para a vida adulta, assim como vai além de um intervalo de idade. Conceituar a juventude como algo único, generalizando, poderia acabar por ignorar que existem juventudes, no plural.

\section{Jovens e a Cidade}

As relações sociais que produzem o espaço urbano não resultam apenas em formas materiais e funcionais, elas perpassam o processo de produção capitalista. Se vamos falar sobre juventude e território, é importante lembrar que o esta relação de pesquisa na Geografia é algo muito recente, principalmente no Brasil. Durante muito tempo essas questões foram tratadas por outras ciências sociais, como a antropologia e a sociologia. As sociabilidades juvenis estão relacionadas em termos de processos culturais que, como tradições, implicaria uma imersão etnográfica sobre as condições, atributos e significâncias internas da cultura juvenil instituída, estudada em profundidade. Porém, os processos interculturais, em tempos de globalização, se ampliaram pela modernização dos equipamentos e possibilidades de comunicação intercontinental.

As culturas juvenis se pluralizam porque suas construções simbólicas locais foram disseminadas pelos processos de comunicação global ampliada. Isso implicou, localmente, as transformações das identidades juvenis locais e sobre como se apresentam individual e coletivamente por entre um mundo social dos adultos. Segundo Silva (2007, p. 22) "na sociedade urbana industrial, os indivíduos e grupo de indivíduos estabelecem relações multidirecionais das mais variadas formas."

As representações dos grupos não são homogêneas, mesmo que o espaço urbano pareça se encaixar em um padrão repetitivo. $O$ território adquire um papel social em sua constituição, porque é a partir dele que as relações sociais juvenis irão acontecer. Em seu caminho, Silva (2007, p. 23) ainda fala que "a cidade apresenta-se com uma sobreposição, articulação, justaposição de territórios" (juvenis). Nestes espaços os grupos apresentam uma estrutura que estabelece pactos e contribuem para a formação de outros territórios. No que se considera juventude há diversos indivíduos e grupos que se conectam com produções 
estéticas e comunicacionais juvenis de outros lugares e instituem localmente seus comportamentos e formas de apresentação de seus corpos, sempre em um movimento contraditório tanto de busca de identidade e igualdade, como de diferença e autenticidade.

É notório que existem mais espaços de sociabilidades juvenis em uma cidade mais populosa que uma cidade pequena ou média, principalmente pelo cosmopolitismo dado pelos processos migratório e pelo adensamento técnico e comunicacional que é mais intenso. Isso faz com que as experiências juvenis sejam diferentes em diferentes contextos urbanos locais e regionais, dado pela capacidade técnica, comunicacional e consumidora da sociedade local. A vida cotidiana de cada jovens é estruturada de acordo com a realidade de consumo e de cada cultura e de como isso se realiza em seus contextos urbanos imediatos de vida. Se pensarmos de forma interseccional, mesmo se vivendo em uma cidade de intensa quantidade e qualidade de serviços coletivos de diversão juvenil, um/a jovem acessa diferentemente tais serviços e, assim, estabelecerá diferentes estratégias de se formas e se apresentar como jovem, infelizmente marcado pelo acesso diferenciado ao consumo urbano contemporâneo.

\section{RESULTADOS}

Como já mencionado na metodologia, foi organizado um grupo de debates e discussões sobre as experiências socioespaciais das juventudes. Partiu-se do pressuposto que existam certos aspectos representativos em ser jovem na sociedade atual, mas que, ao mesmo tempo, as experiências juvenis são muito diversas, implicando realidades, limites e possibilidades em ser e se expressar como jovem em diferentes contextos cotidianos.

Nessa perspectiva, a partir da constituição desse grupo composto por jovens universitários, foram coletadas narrativas sobre situações vividas e os significados que esses mesmos jovens deram para essas vivências, visando estabelecer o que é, para esse grupo de participantes, ser jovem. Então, partindo da questão "Existe um significado único compartilhado socialmente sobre ser 
jovem? " e de narrativas que surgiram em resposta a essa indagação, discorrer-se-á sobre o significado de juventude.

\section{Sobre a condição juvenil - o que é ser jovem?}

Vale ressaltar que, anteriormente à modernidade, não havia uma distinção rigorosa entre grupos etários e, sendo assim, não se denominava algo de juventude - a juventude é um fenômeno moderno, cada vez mais plural (CARDOSO; TURRA NETO, 2011). Neste sentido, um dos jovens participantes do grupo de discussão construído durante a pesquisa, logo no início do diálogo, apresentou suas percepções de ser jovem calcada na ideia de uma faixa etária, questionando em qual idade começa a juventude, o que demonstra que entre jovens, também pode haver esse entendimento que demonstramos em teoria. Outros jovens participantes do grupo trouxeram que existe um entendimento, considerado senso comum, do que é ser jovem, e, dentro desse consenso comum, existem algumas condições consideradas juvenis, dentre elas a transição para a vida adulta, a rebeldia, a fase de descoberta. Ao mesmo tempo esses jovens pesquisados afirmaram que, para eles, a juventude vai além, como pode-se ver nas narrativas apresentadas a seguir:

Eu fui criada em um contexto onde ser jovem é exatamente o que julgam socialmente (ir para festas, se descobrir, transição para a vida adulta, rebeldia, imaturidade e etc). Mas hoje com uma liberdade de pensamento maior eu acredito que ser jovem vai além disso -Florence (nome fictício)

Acredito que esse significado no senso comum seja considerado uma fase de descobertas, tanto fisiológicas como no meio social, é aquele que está em certa forma, buscando aprovações [...] No entanto, quando se analisa mais a fundo, eu acredito que há diversas variações presentes de acordo com a realidade daquela pessoa, existem jovens que por conta da cultura não vivenciam as mesmas experiências de outros, existem alguns ainda que por conta de situações que ocorreram quando mais novos, "pularam" essa fase por serem obrigados a terem outras responsabilidades, e mesmo quando "jovens", não participam na totalidade das experiências (experiências juvenis). - Roberto (nome fictício)

Algo que pode ser considerado relevante, e que apareceu nas narrativas, é a relação com o contexto. Os jovens participantes do grupo de discussão trouxeram que para ser efetivamente jovem é necessário ter acesso a algumas con- 
dições de vivência, o que podemos pensar através da interseccionalidade. Helena (nome fictício) traz que...

Pra ser efetivamente jovem, isso quer dizer pra mim que ser jovem é um estado do meu desenvolvimento, então quer dizer mais sobre como eu tenho condições em viver [...] Então não, eu não consigo ser efetivamente jovem porque minha condição financeira, emocional, ambiental, enfim, um leque de coisas precisam melhorar.

Com isso ela traz que, a partir do seu entendimento, a condição de classe, psicológica e ambiental (contextual), influencia na forma do jovem vivenciar a sua juventude, podendo, inclusive, não permitir que essa juventude seja vivenciada. A questão do contexto aparece também na fala de outros jovens, tais como na narrativa de Pedro (nome fictício) que nos trouxe que ser jovem é carregado de estereótipos.

Quanto aos estereótipos, como apresenta Pedro em seu entendimento, é sabido que a temática juventude é construída a partir de rotulações: delinquência, rebeldia, contestação, etc (GAMALHO, 2020). Além das rotulações, há o caráter de transição: jovem ainda não é um sujeito totalmente completo? A completude vem com a fase adulta? O contexto aparece, também, na narrativa de Joaquim (nome fictício) quando ele fala que o significado de juventude:

Se molda de acordo com a realidade social de cada indivíduo, pluralmente falando. E que essa juventude nos perpassa ao longo da vida.

Ainda sobre isso, tem-se o relato de Florence (nome fictício), jovem que possui sua juventude perpassada pela necessidade do trabalho, a qual nos traz que em um contexto de jovem trabalhador o ser jovem é carregado de questionamentos sobre quem se é, e sobre o papel na sociedade.

Diante do exposto, como fica a juventude dos jovens que precisam conciliar trabalho e estudo? Nesse sentido, pode-se pensar a interseccionalidade: jovens de periferia vivenciam a juventude de forma distinta de jovens de classe média ou alta, por exemplo. É necessário se pensar o contexto! Cardoso e Turra Neto (2011) trazem que, inclusive em um mesmo contexto social e espacial, é viável que se encontre variadas juventudes - formas de ser jovem - e que é possível, 
dessa forma, "estabelecer paralelos entre a diversidade juvenil e a multiplicação de contextos sócio-espaciais, dentro de uma mesma cidade" (p. 4. Com as narrativas juvenis apresentadas podemos perceber que há diferentes contextos em uma mesma cidade: a cidade e a juventude são vivenciadas de forma diferente pelas pessoas diversas.

Nola Gamalho (2020) afirma que ao se pesquisar juventude é necessário criar mecanismos para maior interação entre pesquisadores e pesquisados. Partindo dessa perspectiva, outro resultado oriundo da interação entre o grupo de pesquisadores e pesquisados foi uma playlist colaborativa (ou seja, criada em conjunto) no aplicativo Spotify, que foi pensada como forma de maior interação entre os participantes, para gerar também o diálogo. Tanto os pesquisadores quanto os jovens participantes inseriram músicas.

Figura 1: Playlist Colaborativa Grupo Juventudes.

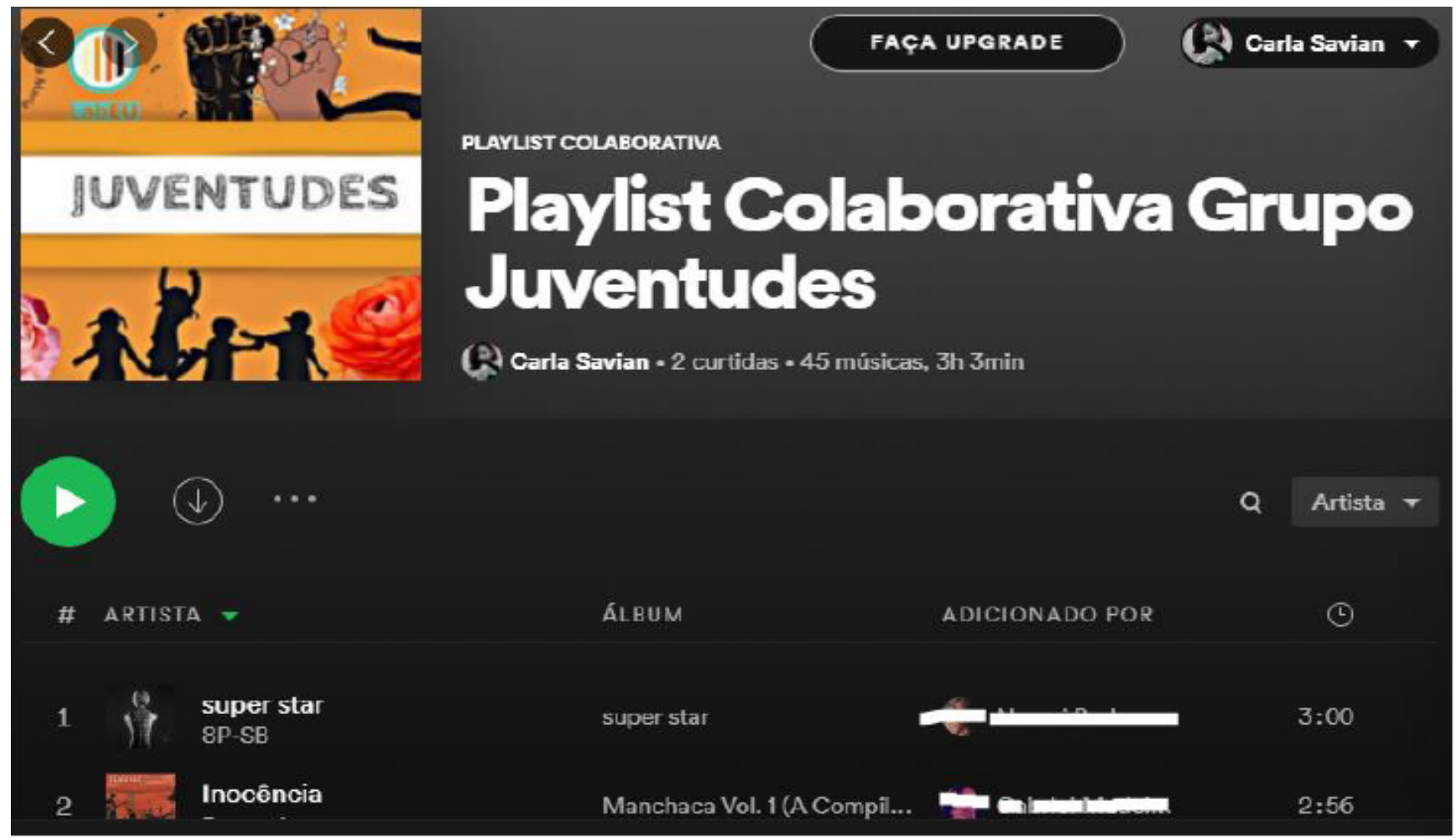

Fonte: Organizada pelos participantes.

Na playlist que ficou intitulada "Playlist Colaborativa Grupo Juventudes" foram inseridas 45 músicas de diversos estilos musicais, sendo algumas referen- 
tes ao ser jovem, tais como "Não é Sério" de Charlie Brown Jr. Também foram inseridas músicas relacionadas a questões feministas, das cantoras Elza Soares e Mc Carol, mas também apareceram músicas que falam sobre a questão social, como "Construção" de Chico Buarque, por exemplo, e outros diversos assuntos - a playlist mostrou-se plural, assim como o grupo. Com esta atividade, notamos que a música é uma parte importante da identidade de cada jovem e que contribui com cada vivência e experiência.

De acordo com Arroyo (2013), as constituições dos jovens são permeadas pelas práticas musicais, ao passo que constroem novas. Sendo a música parte da juventude, participando das diversas formas de ser jovem.

\section{CONCLUSÃO}

Observa-se que o texto não objetivou construir uma conceituação única para a juventude, mas sim demonstrar a pluralidade juvenil encontrada nas vivências dos jovens participantes dos projetos discutidos e apresentados, propósito que foi alcançado. Considera-se que as metodologias utilizadas proporcionaram uma pesquisa participativa, facilitando interações e diálogos entre pesquisadores e pesquisados, resultando em narrativas significativas sobre o ser jovem e o viver a juventude.

É possível perceber que além de pluralidades de vivências e formas de existências, é de pluralidades contextuais que se trata - os contextos são diversos e as vivências são envoltas aos contextos -, o que pode ser vinculado à teoria da interseccionalidade, por exemplo.

Os jovens demonstraram que existem espacialidades e sociabilidades diferentes. As práticas juvenis são novas e as possibilidades de interação são diferentes. A juventude é uma categoria que durante muito tempo foi negada de estudo dentro da Geografia, pois era entendida de forma errônea. A condição juvenil está relacionada com as condições socioeconômicas e também aos processos políticos e culturais. 
Com a visibilidade social da juventude em alta, torna-se necessário entender como ela se dá e como ela se forma. A Geografia auxilia o entendimento sobre as expressões e vivências juvenis, assim como suas espacialidades. Têm-se então que as trajetórias percorridas pelos jovens controem espaços de sociabilidade, não sendo o espaço apenas palco de um acontecimento, mas também limitador ou possibilitador de determinados acontecimentos.

\section{REFERÊNCIAS}

ABRAMO, H. Considerações Sobre a Tematização Social da Juventude no Brasil. CLAM - Centro Latino-Americano em Sexualidade e Direitos Humanos, n. 5, 1997. Disponível em: http://www.clam.org.br/bibliotecadigital/uploads/publicacoes/442_1175_abramowendel.pdf. Acesso em 09 ago. 2021.

ARROYO, Margarete (Org). Jovens e músicas: um guia bibliográfico. São Paulo: Editora Unesp, 2013. ISBN 9788539304257 Disponível em: <http://hdl.handle. net/11449/113711>. - Acesso em: 15 jul. 2021.

CARDOSO, D. S. da.; TURRA NETO, N. Juventude, Cidade e Território: esboço de uma geografia das juventudes. In: Seminário de Pesquisa Juventude e Cidade, 1, 2011, Juiz de Fora. Disponível em: https://www.ufjf.br/nugea/files/2019/09/ JUVENTUDE-CIDADE-E-TERRIT\%C3\%93RIO-ESBO\%C3\%87OS-DE-UMA-GEOGRAFIA-DAS-JUVENTUDES.pdf. Acesso em: 22 jul. 2021.

COLLINS, P. H. Se Perdeu na Tradução? Feminismo negro, interseccionalidade e política emancipatória. Tradução Bianca Santana. Parágrafo, v. 5, n. 1, jan-jun, 2017. Disponível em: http://revistaseletronicas.fiamfaam.br/index.php/recicofi/article/view/559/506. Acesso em 22 jul. 2021.

CRENSHAW, K. Documento para o encontro de especialistas em aspectos da discriminação racial relativos ao gênero. Revista Estudos Feministas. Ano 10, n. 180. Florianópolis: primeiro semestre, 2002. Disponível em: https://www.scielo. $\mathrm{br} / \mathrm{j} / \mathrm{ref} / \mathrm{a} / \mathrm{mbTpP} 4 S F X P n J Z 397 j 8 f S B Q Q /$ ?lang=pt\&format=pdf. Acesso em 22 jul. 2021.

DUARTE, A. B. S. Grupo Focal Online e Offline Como Técnica de Coleta de Dados. Inf. \& Soc.: João Pessoa, v.17, n.1, p.75-85, jan./abr., 2007. Disponível em: https://www.brapci.inf.br/_repositorio/2010/11/pdf_51bcc64139_0012782.pdf. Acesso em 02 ago. 2021. 
GAMALHO, N. P. Juventudes do Guajuviras: percursos em comunidades de sentidos. Textura. V. 22 n. 49. Canoas-RS: ULBRA, 2020. Disponível em: http://www. periodicos.ulbra.br/index.php/txra/article/view/5066. Acesso em: 22 jul. 2021.

GAMALHO, N. P.; HEIDRICH, A. L. "A gente é da vila mas não é bandido!" O lugar e a juventude nas representações sociais dos jovens do bairro Grajuviras - Canoas/RS - Brasil. Para Onde? v. 6, n. 1, p.57-63, jan./jun, 2012. Disponível em: https://www.lume.ufrgs.br/handle/10183/122642. Acesso em 22 jul. 2021.

LINDÓN, A. De las geografías constructivistas a las narrativas de vida espaciales como metodologías geográficas cualitativas. Revista da ANPEGE. v. 4, 2008.

MAYORGA, C. Algumas palavras de uma feminista sobre o campo de estudos sobre juventude. In: COLAÇO, V.; GERMANO, I.; MIRANDA, L. L.; BARROS, J. P. (orgs). Juventudes em Movimento: experiências, redes e afetos. Fortaleza: Expressão Gráfica e Editora, 2019. p. 132-141. Disponível em: https://pospsi.ufc. br/wp-content/uploads/2019/06/livro-vii-jubra-colaco-germano-miranda-e-barros-orgs.pdf\#page=67. Acesso em: 15 jul. 2021

ROCHA, N. M. F. D. A perspectiva do feminismo interseccional e decolonial no enfrentamento do racismo e sexismo na vivência com a juventude universitária. In: COLAÇO, V.; GERMANO, I.; MIRANDA, L. L.; BARROS, J. P. (orgs). Juventudes em Movimento: experiências, redes e afetos. Fortaleza: Expressão Gráfica e Editora, 2019. p. 132-141. Disponível em: https://pospsi.ufc.br/wp-content/uploads/2019/06/livro-vii-jubra-colaco-germano-miranda-e-barros-orgs.pdf\#page=67. Acesso em: 15 jul. 2021.

SILVA, J. M. Cultura e territorialidades urbanas-uma abordagem da pequena cidade. Revista de História Regional, UEPG Ponta Grossa, v. 5, n. 2, 2007.

THIOLLENT, M. A inserção da pesquisa-ação no contexto da extensão universitária. In: BRANDÃO C. R.; STRECK, D. R. (Org.). Pesquisa participante: o saber da partilha. São Paulo: Ideias \& Letras, 2006. p. 151-166. 


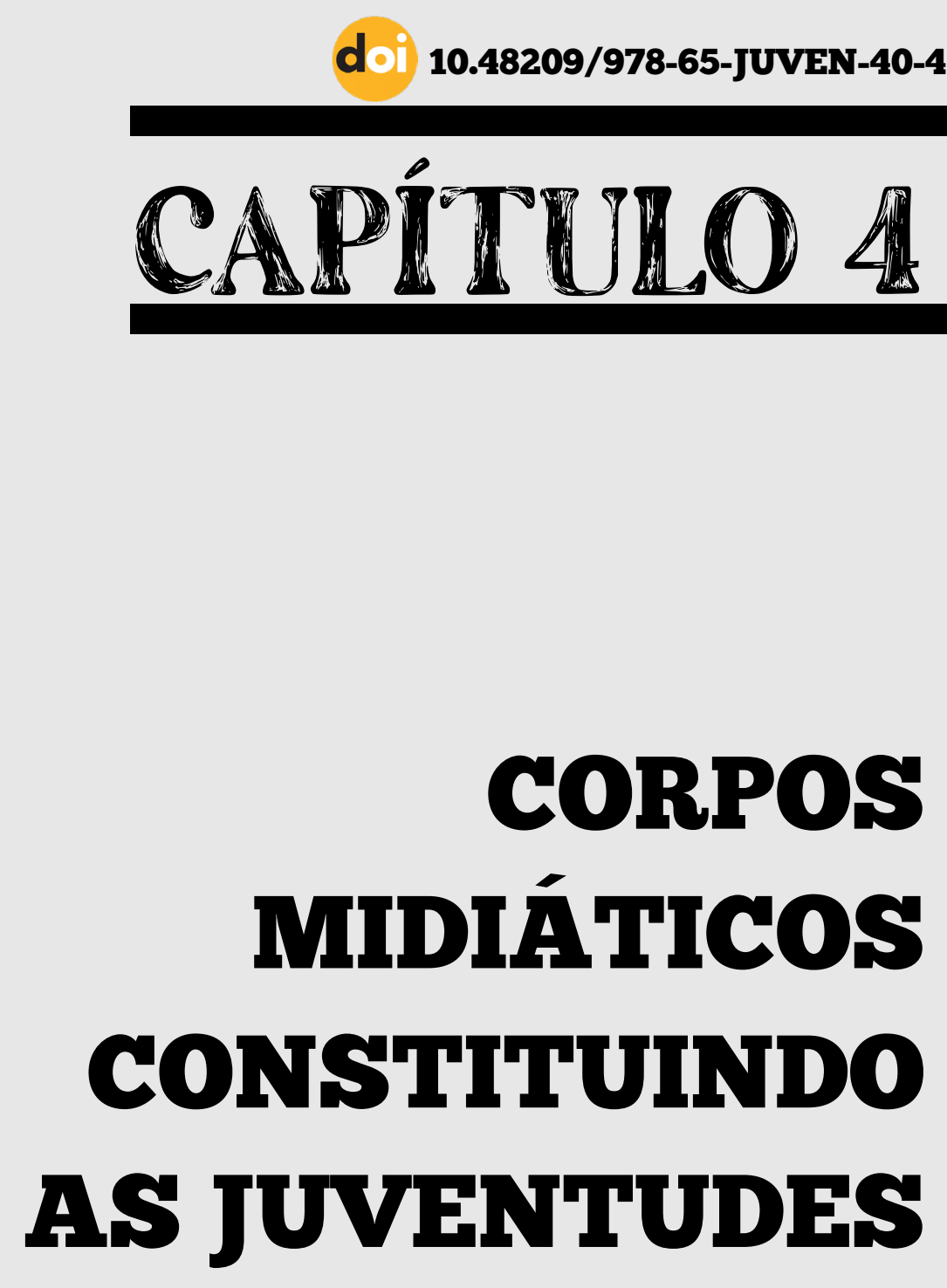

Katiele Hundertmarck 


\section{INTRODUÇÃO}

Ter um corpo gordo, no momento histórico, social e cultural que estamos, parece um pesadelo, algo extremamente indesejável e associado ao descaso com a saúde, relaxamento, falta de autocuidado, feiura, sujeira, doença (JIMENEZ, 2020) e algo a ser evitado a diversos custos: dietas restritivas, exercícios físicos intensos e focados na perda de peso e estética corporal: em geral, ter um corpo magro jovem sexualmente desejável.

A incansável busca por esse corpo "ideal" perpassa por padrões estabelecidos no contato com o outro, além das questões biológicas, se dá na sociedade, pois, como afirma Tovar (2018, p. 13), “[...] nós não nascemos pensando que ser gordo é ruim e ser magro é bom. Nós aprendemos essas coisas por meio da cultura". Ou seja, na convivência e nas influências constituídas e mediadas por relações de poder nas diferentes instâncias: familiares, escolares, médicas, midiáticas, e outras que vão produzindo modos de ser e estar no mundo, nos dizendo como devemos nos portar diante das diversas situações vivenciadas.

Isso significa dizer que nossos corpos vão sendo produzidos, também, pelas mídias, como a análise proposta nessas provocações. De acordo com Bento (2017), os corpos são construídos a partir do texto social, o que corrobora com a compreensão de Nascimento (2021, p. 59) ao justificar que "[...] não somos corpos, fazemos corpos", ampliando a discussão para que nós também vamos modificando, performando e construindo nossos próprios corpos a partir dos nossos contextos.

Por conseguinte, essa idealização de um único corpo aceitável como "padrão" pode estar contribuindo com comportamentos alimentares de risco, como os transtornos alimentares anorexia e bulimia (FONTANAZI, PEREIRA, 2019). A influência das mídias no comportamento alimentar de jovens é uma realidade, pois podem estimular a excessos e restrições em busca de um corpo "atlético" e "saudável" para mascarar a impreteriosa pretensão de um corpo magro e eternamente jovem (FONTANAZI, PEREIRA, 2019, p. 403). 
Diante disso, objetiva-se discutir sobre as mídias na produção de corpos e subjetividades juvenis para problematizar a padronização de um corpo universal a ser alcançado e suas reverberações nos transtornos alimentares e qualidade de vida das juventudes. Para isso, utiliza-se de análise de um artefato cultural, uma publicação de uma revista, para identificar as pedagogias culturais presentes e promover a discussão. Os campos teóricos que sustentam a argumentação decorrem dos Estudos Culturais na perspectiva pós-estruturalista.

\section{DESENVOLVIMENTO}

As juventudes contemporâneas estão associadas a flexibilização de algumas antigas restrições, como a idade, por exemplo, podendo sentir-se jovem alguém de quarenta anos, visto que é uma categoria dinâmica. Contudo, os marcadores legais delimitam à idade cronológica, em que é considerado adolescente alguém de 12 a 18 anos, de acordo com o Estatuto da Criança e do Adolescente (BRASIL, 1990) ou jovem, de 15 a 24 anos, de acordo com a Organização pelas Nações Unidas (ONU, 2021).

No campo dos Estudos Culturais e de Gêneros em sua vertente pós-estruturalista, as juventudes contemporâneas são compreendidas como construções constituídas e diferenciadas discursivamente, a partir dos contextos históricos e sociais em que estão inseridas (VARGAS, 2016). Isso permite pensar que ser/ estar jovem é algo fluído e temporal, percorrendo diferentes dimensões ao longo da história moderna, a partir da qual a categoria juventudes ganha uma modalidade de "etapa" da vida. Essa perspectiva agrega potencialidade de se construir estudos e políticas públicas com foco para essa fase do desenvolvimento humano, considerando as particularidades e as necessidades coletivas, a priori, que podem sugestionar um direcionamento individual, à medida de sua extensão.

As formas como as experiências sociais das/os jovens são manifestadas em decorrência dos estilos de vidas e produções do "tempo livre" são consideradas as culturas juvenis. São essas as produções ao longo do contexto histórico que vão constituindo modos de ser e estar juvenil (VARGAS, 2017). 
De acordo com Vargas (2017, p. 189):

[...] na atualidade, certas características tais como beleza, espontaneidade, vitalidade e versatilidade acabam por ser naturalmente associadas à condição juvenil e são exaltadas por diversos discursos circulantes em nossa sociedade, a exemplo do discurso midiático e do discurso médico.

Nesse contexto, as subjetividades jovens vão sendo fabricadas pelos discursos reiterados dos diversos dispositivos, como as linguagens midiáticas. As pedagogias contidas nesses artefatos culturais vão produzindo modos de ser e estar dentro da sociedade, nesse caso, dizendo que os jovens devem ser "belos", "saudáveis", e "versáteis" condizendo com a ideia de um único modo desejável de ser jovem. Concomitante a isso, vão fabricando corpos consumidores dos produtos "milagrosos" que podem fazer emergir o corpo único desejável.

Problematizando para o foco da discussão proposta, um corpo jovem a ser almejado é aquele que potencializa atração no contato com o outro, ou seja, um corpo a ser desejado, o que vai ao encontro de captar as/os jovens para essa busca pelo enquadramento da "beleza" a qualquer custo. Esse fato é tão real que o número de cirurgias plásticas entre jovens aumenta a cada ano, dado o crescimento da insatisfação com a imagem corporal. De acordo com Lourenço (2021), houve um aumento de mais de $140 \%$ no número de procedimentos estéticos entre jovens brasileiras/os. Por isso também é importante marcar o espaço das mídias na construção dos "padrões" de "beleza", na produção de imagens manipuladas e o quanto as juventudes contemporâneas estão submetidas nesse contexto, por vezes, insensíveis a essas questões dos "bastidores" da "beleza" fabricada e publicizada.

Para Goellner (2013, p. 30), o corpo é

provisório, mutável e mutante, suscetível a inúmeras intervenções consoante o desenvolvimento científico e tecnológico de cada cultura bem como suas leis, seus códigos morais, as representações que cria sobre os corpos, os discursos que sobre ele produz e reproduz.

Os corpos, ainda em seus aspectos biológicos, são mediados pela cultura, revelam a qual tempo foram educados e produzidos de forma contínua e minucio- 
sa (GOELLNER, 2010). Por exemplo, quanto aos modos de se vestir, os sujeitos são influenciados pelas tendências da moda, pelas propagandas que dizem qual a melhor roupa para o seu "tipo" de corpo, e ainda, que o corpo precisa caber naquela roupa para adentrar ao socialmente aceito. E, se o corpo não couber, já deve ser instruído sobre o que fazer para entrar naquele manequim, como muito ensinado nas revistas brasileiras desde sempre.

Pelúcio (2014) ao discutir sobre mídias e constituição dos sujeitos, convida para o questionamento do potencial que essas têm de seduzir as pessoas ao pedagogizar, reproduzindo as normas sobre masculino, feminino, classe, raça, orientação sexual e também de criar "verdade" sobre essas questões. Pode-se pensar que essas mídias também tentam produzir alguma representação que faça sentido para quem se destina (HALL, 2016). Além disso, as mídias buscam recrutar as/os jovens para enquadrá-las/os na "norma" e assim, por conseguinte, torná-las/os consumidores dos produtos que anunciam. Afinal, as mídias pedagogizam que as/os jovens somente serão felizes se couberem naquela tal roupa da moda, se utilizarem tal creme redutor de medidas, se tiverem tal corpo "belo, saudável e desejável", que é algo inatingível e por isso mesmo, exige muitos esforços constantes, dos quais, quem não está "afim" de alcança-lo deve ser excluído, rechaçado, penalizado.

Logo, as mídias como produtoras dessas "verdades" sobre os corpos, vão conduzindo a ideia de que somente a pessoa, em sua individualidade, é capaz de fazer "boas" escolhas e conquistar esse tal corpo dos "sonhos" e não possibilita a análise social, cultural e histórica que fabrica modos coletivos que nos ensinam sobre quais corpos têm legitimidade para viver (e exercer plenamente os direitos) e quais estão marcados e podem, assim, sofrer (e não usufruir desses direitos). Quero problematizar com isso que as transformações corporais realizadas pelas/ os jovens em busca desse "padrão" de "beleza" não são meramente escolhas individuais, mas sim, fortemente mediadas pelas pedagogias culturais presentes nas mídias. 
Essa busca pelo corpo magro padronizado, em resposta às exigências sociais midiáticas estabelecidas, pode contribuir com certos transtornos alimentares que acometem as/os jovens. Alguns desses comportamentos alimentares de risco podem ser persistentes, tornando-se transtornos alimentares. $\mathrm{Na}$ anorexia, os três importantes critérios diagnósticos são a restrição da ingesta calórica em relação às necessidades corporais, o medo de engordar e a alteração na percepção do peso ou forma do corpo (FONTANAZI, PEREIRA, 2019). Na bulimia, há presença de frequentes episódios de compulsão alimentar seguidos de comportamentos compensatórios, como os vômitos autoinduzidos, uso de laxantes, diuréticos, jejuns e/ou atividade física em excesso (FONTANAZI, PEREIRA, 2019).

Esses transtornos alimentares podem acometer dez mulheres a cada um homem, reforçando a prevalência das identidades femininas desses diagnósticos (FONTANAZI, PEREIRA, 2019). Esse achado nos permite inferir que as questões desiguais entre os gêneros também podem estar mediando essas construções, por base da sociedade machista, racista, sexista, misógina e patriarcal que oprime e violenta às identidades femininas, sendo, desse modo, necessário contemplar as interseccionalidades como marcadores sociais desses transtornos nas juventudes.

De acordo com Baptista e Hercowitz (2021), homens cis gays e bissexuais expressam elevada preocupação com a comida e a aparência física, as mulheres cis lésbicas e bissexuais estão submetidas a maior risco de dietas agressivas e danosas e as mulheres trans, ainda que negligenciadas nas pesquisas sobre os transtornos alimentares, apresentam intensa busca pela magreza, também em decorrência do alcance da aparência de um corpo feminino e os homens trans, com mais preocupações com peso e forma corporal em comparação aos homens cis (BAPTISTA, HERCOWITZ, 2021). Em especial, na população trans, a repulsa social relacionada ao corpo pode gerar sofrimentos intensos e para aquelas que já tem algum transtorno alimentar, há mais riscos de comportamentos autolesivos, incluindo ideação e tentativa suicidas (BAPTISTA, HERCOWITZ, 2021). 
Pelo supracitado, considerar esses comportamentos alimentares de risco como potencializadores para o desenvolvimento de alguns dos transtornos alimentares de risco é pensar sobre como a sociedade ocidental, ao longo da história, tem conduzido o processo saúde-doença e a qualidade de vida mediados pelas questões culturais (e suas pedagogias).

Dessa forma, o reconhecimento de como os artefatos culturais podem conter pedagogias que ensinam modos de ser e estar, pode instigar a problematizar os usos da cultura, e seu consumo, como mecanismos de transpor alguns "padrões", como os relacionados com a fabricação de corpos. Os artefatos culturais são músicas, filmes, novelas, revistas, redes sociais, charges, jornais, propagandas, programas de rádio e televisão, entre outros e são potentes instrumentos pedagógicos para a produção de sujeitos e construção de suas identidades, pois educam sobre as formas relacionadas aos comportamentos, difundindo práticas e discursos que conduzem os modos de ser e estar em sociedade (AMARAL, CASEIRA, MAGALHÃES, 2017). Por isso, pensar sobre as pedagogias culturais presentes nesses artefatos é importante para problematizar como constituinte dos sujeitos, ao propagar valores, costumes e "verdades" como algo quase que incontestáveis (AMARAL, CASEIRA, MAGALHÃES, 2017).

\section{RESULTADOS E DISCUSSÃO}

Para contribuir com a discussão, analisa-se, como disparador da problemati-zação, a polêmica matéria da revista estadunidense National Enquirer (Figura 1) que repercutiu em algumas redes sociais no Brasil, ao publicar em 02 de agosto de 2021, "os 50 corpos melhores e piores corpos de praia deste ano" e pensar sobre possíveis repercussões com transtornos alimentares, haja vista que para se chegar ao dito corpo "bom" são necessárias estratégias, das quais, podem levar algumas pessoas ao desenvolvimento de comportamentos alimentares de risco e transtornos. 
FIGURA 1: Revista National Enquirer (2021).
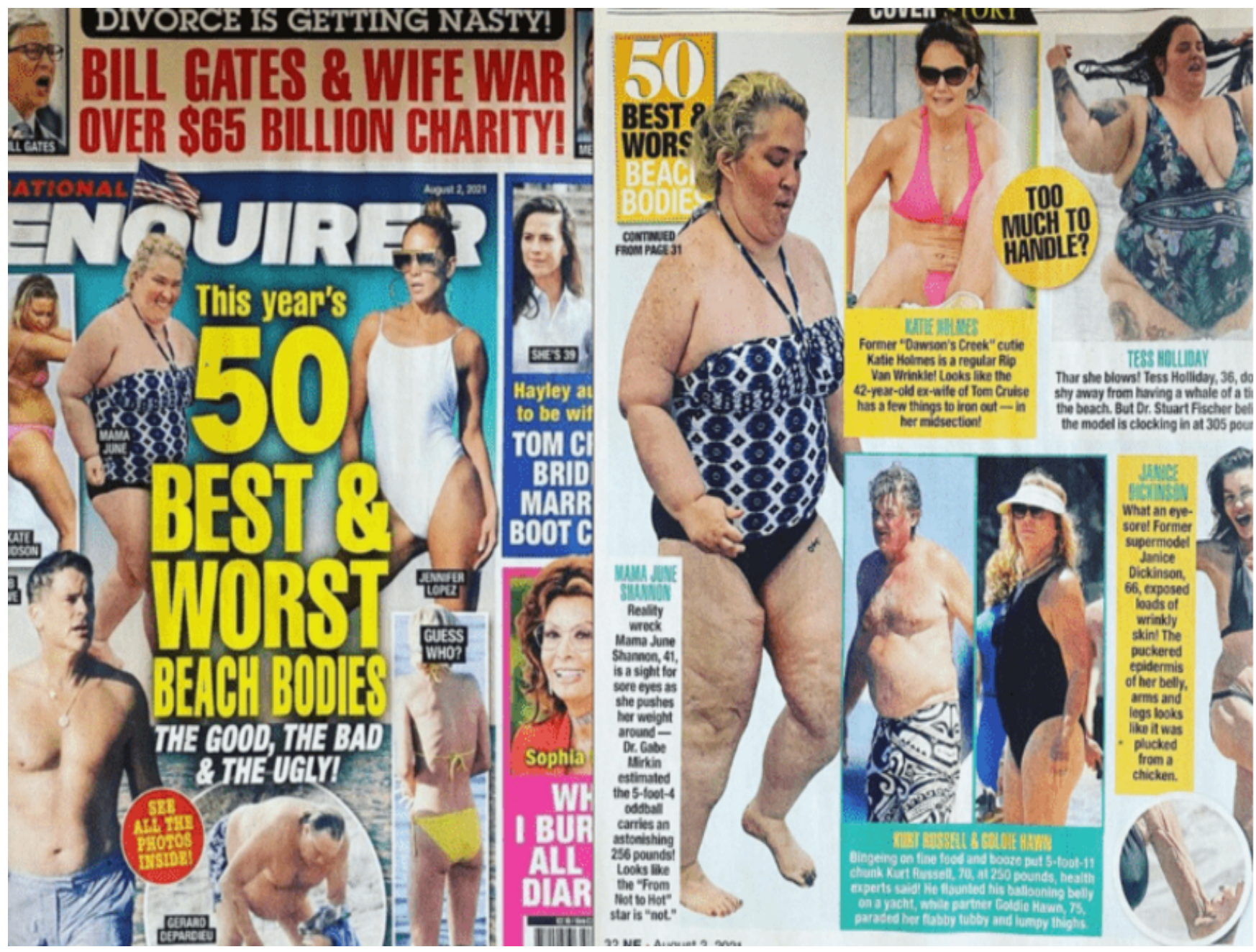

FONTE: LAMBERT, Tarla. '50 Worst beach bodies' was an actual headline in 2021. Disponível em: <https://womensagenda.com.au/life/50-worst-beach-bodies-was-a- legitimate-headline -in-2021-we-need -to-do-better/> . Acesso em: 03 ago 2021.

A referida matéria analisa alguns corpos e categoriza, classificando alguns como bons, outros ruins e ainda alguns como muito ruins. Ao colocar fotos de corpos, faz uma análise baseada nos padrões "ideais de beleza", ressaltando o que diz como imperfeições e escrevendo sugestões: malhar um pouco mais, fazer uma dieta, usar uma roupa mais adequada. O que fica evidenciado na publicação são às críticas às diversidades de corpos, o julgamento de corpos alheios, exposição das imagens das pessoas e levanta algumas questões, insinuando que nem todos os corpos podem/devem ir à praia, quais podem ir e o que os corpos que não estão nesse padrão devem fazer para enquadrarem-se às normas estéticas. 
Como são constituídos social e culturalmente, "[...] os corpos estão sempre sendo classificados com aprovação ou reprovação dentro do termômetro social, o qual define como nossos corpos devem ser [...]" (JIMENEZ, 2020, p. 63). Para aquelas "[...] pessoas que não se adaptam ao que está instituído socialmente, por consequência, são marcadas, estigmatizadas e excluídas do convívio e da obtenção de direitos" (JIMENEZ, 2020, p. 61).

Os significados atribuídos às imagens e as escritas pela revista sugerem a manutenção e a produção de corpos considerados "ideais", reforçando que todas as pessoas que estão com seus corpos não "ideais" devem esconderem-se ou projetarem mudanças corporais para que possam, de fato, frequentarem os espaços e exporem seus corpos. A intenção da matéria dessa revista é que todas as pessoas busquem os corpos de praia: "bonitos", "jovens", "malhados", "firmes", sem estrias, sem celulites, sem rugas, ou seja, sem singularidades, padronizados no momento histórico, cultural e social atual que supervaloriza corpos esbeltos, atléticos, vigorosos, uniformes!

Para Andrade (2013, p. 121):

[...] os discursos das revistas femininas estão envoltos em relações de poder, poder de regular as condutas, de dizer como agir, o que comer, que atividades físicas praticar, em que horário e local, que roupas estão na moda, etc.

Andrade (2013) afirma que somos, a todo momento, bombardeados por informações que chegam, em parte, pela mídia e que essa nos ensina como devemos nos relacionar com o mundo, "[...] informações que se pretendem verdadeiras e universais" (ANDRADE, 2013, p. 111). Assim, há interpelações às/aos leitoras/es para que situem seus corpos no binarismo bom/ruim e que as ditas "verdades" sobre os corpos devem ser absolutas e inquestionáveis, afinal, quem não tem um corpo de praia, não tem espaço na praia - e, por analogia, em nenhum outro espaço social. Logo,

[...] é possível pensar as revistas voltadas para o público feminino, tanto infantil como adulto, como um artefato pedagógico que exerce 
poder sobre as mulheres e meninas, ensinando técnicas de como lidar com o corpo (ANDRADE, 2013, p. 111).

Então, vão se constituindo modos de ser e estar com os corpos, uns corpos classificados "verdadeiramente" como bons e outros como ruins, muito ruins. $O$ que fica para as/os leitoras/es é de que para se ter um corpo bom (e esse parece estar sendo o desejo de todas/os, pois não se almeja ser excluída/o, sofrer violências, preconceitos, ódio), precisa-se fazer os sacríficos recomendados e caso não os consiga, é considerado como um fracasso individual, sem ao menos questionar as influências sociais nessas questões (TOVAR, 2018, JIMENEZ, 2020).

Figueira (2013, p. 129), ao pesquisar sobre representações do corpo feminino na revista Capricho, afirma que as imagens e textos "[...] estão não apenas orientando, acompanhando e informando as leitoras sobre os usos do seu corpo, mas estão, sobretudo, produzindo esse corpo". Além disso, a referida revista incentiva em diversas situações que suas leitoras percam peso, façam dietas, controlem a alimentação (FIGUEIRA, 2013).

Em específico na questão das mulheres, de acordo com Wolf (2020, p. 27), a beleza "[...] se fortaleceu para assumir a função de coerção social que os mitos da maternidade, domesticidades, castidade e passividade já não conseguem impor". Assim, "[...] o mercado da beleza tem um papel fundamental no impulsionamento do consumo para ser ou manter-se magra, bela e saudável" (JIMENEZ, 2020, p. 103). Esse mercado da beleza adquiri dimensões muito além de deixar as pessoas "bonitas", mas sim, de ocupar, em especial, as mulheres, com as questões envolvidas em estar sempre "bela", na constante preocupação em estar "se cuidando", utilizando diversos produtos e medicamentos para a aquisição/compra desse corpo "ideal" em detrimento das mulheres estarem atentas a outras situações decorrentes do sexismo, machismo, patriarcado, capitalismo que tanto oprimem e violentam às mulheres. Nesse sentido, Wolf (2020) provoca à reflexão de que mulheres com fome não conseguem lutar pelos seus direitos. 
Então, as mídias, como a matéria da revista em análise, permitem inferir que está a serviço desse mercado da "beleza" que dita, a todo momento, o que é "beleza" e por que todas as mulheres, e cada vez mais, os homens também, devem estar em constante alcance desse padrão afim de estabelecer uma relação entre estar bela/o e ter saúde e ser, assim, socialmente aceita/o. De acordo com Andrade (2013, p. 118),

[...] percebe-se que a promoção do que é hoje tomado como saúde, como cuidados com o corpo e concomitante à insatisfação do ser humano, pas-sa, necessariamente, primeiro, por uma mudança de hábitos alimentares, pela reeducação e pelo número sem fim de dietas.

A narrativa de associar "beleza" com a saúde, pode mascarar a gordofobia, que é uma forma de preconceito com base em ter ódio/nojo/aversão ao corpo gordo (TOVAR, 2018) e promover a falta de acesso das pessoas com corpos diferentes dos magros com os próprios serviços de saúde, contribuindo para o adoecimento e morte das pessoas gordas por doenças que não têm nem relação com à gordura corporal (JIMENEZ, 2020).

De acordo com Tovar (2018, p. 13), "[...] a gordofobia cria um ambiente de hostilidade em relação às pessoas de corpo avantajado, promove um relacionamento patológico com a comida [...]", o que tende a levar as pessoas a comportamentos alimentares de risco, aumentando o ódio com o próprio corpo. Também é importante trazer para a discussão que, em muitas situações, as pessoas não têm a oportunidade de fazer escolhas alimentares saudáveis, sendo, logo, uma questão que deve ampliar-se para um desafio social o acesso à alimentação saudável a toda a população. Aliado a isso, não se pode afirmar que pessoas magras tenham uma alimentação que seja saudável, o que vem ao encontro dos transtornos alimentares, onde a relação com a comida é prejudicada pelo medo de engordar e então, para as pessoas que estão acometidas, as estratégias são voltadas para a tentativa de atingir esse corpo padronizado, ainda que por meios prejudiciais à saúde. 


\section{CONCLUSÃO}

Com os questionamentos, não se pretendeu incentivar à ingestão hipercalórica, hiponutritiva, ou discutir a generalização das doenças em relação aos corpos gordos, mas o que se objetivou problematizar é porque um único tipo de corpo é idealizado, tem-se padronizado, e os demais, inferiorizados, à medida que todas as/os jovens devem esforçar-se para 0 atendimento desse padrão socialmente imposto e caso não atinjam esse corpo desejado/belo/saudável, não podem ocupar os espaços sociais (e seus direitos).

Por conseguinte, a ampliação dessa discussão para a (re)produção dos padrões pela mídia, como a revista em questão, potencializa as imagens corporais boas e as más, constituindo posições de sujeitos, diferenças e identidades (ANDRA-DE, 2013) se faz necessária, na medida em que, propõe às/aos leitoras/es mudanças corporais para o atendimento do corpo "ideal" e assim, podem, a algum modo, contribuir para o acometimento dos transtornos alimentares.

Ao questionar as pedagogias culturais nas mídias e como nos educam sobre como devemos fabricar nossos corpos, reverbera com mais intensidade nas juventudes, que por ora, dispensam certa preocupação com a aparência física e a aceitação pelo olhar do outro, podendo desenvolver diversos agravos à saúde e comprometendo a qualidade de vida, o bem-estar, inclusive, sugerindo, cada vez mais, os sentimentos de não-aceitação, de baixa autoestima, de não-pertencimento. Logo, pensar sobre os produtos culturais que consumimos é importante para analisar sobre os modos de ser e estar que os jovens estão sendo submetidas/os e, de alguma forma, reproduzindo e mantendo esses "padrões".

\section{REFERENCIAS}

AMARAL, Caroline Amaral; CASEIRA, Fabiani Figueiredo; MAGALHÃES, Joanalira Corpes. Artefatos culturais: pensando algumas potencialidades para discussão dos corpos, gêneros e sexualidades. In: RIBEIRO, Paula Regina Costa; MAGALHÃES, Joanalira Corpes (org). Debates contemporâneos sobre Educação para a Sexualidade. 2017. Disponível em: http://repositorio.furg.br/ bitstream/handle/1/7097/debates_contemporaneos_educacao_sexualidade.pdf?sequence=1. Acesso em: 11 jul. 2021. 
ANDRADE, Sandra dos Santos. Mídia impressa e educação de corpos femininos. In: LOURO, Guacira Lopes, FELIPE, Jane, GOELLNER, Silvana Vilodre. Corpo, gênero e sexualidade: um debate contemporâneo. 9. ed. Petropólis: Vozes, 2013. p. 109-123.

BAPTISTA, Vanessa Cristina; HERCOWITZ, Andrea. Problemas associados à ima-gem corporal. In: CIASCA, Saulo Vito, HERCOWITZ, Andrea, JUNIOR, Ademir Lo-pes (org.). Saúde LGBTQIA+: práticas de cuidado transdisciplinar. Santana da Par-naíba: Manole, 2021. p. 420-425.

BENTO, Berenice. Transviad@s: gênero, sexualidade e direitos humanos. Salva-dor: EDUFBA, 2017. Disponível em: https://repositorio.ufba.br/ri/bitstream/ ri/26037/1/Transviadas-BereniceBento-2017-EDUFBA.pdf. Acesso em: 09 set. 2021.

BRASIL. Lei Federal $\mathbf{n}^{\circ} \mathbf{8 . 0 6 9}$, de 13 de julho de 1990. Dispõe sobre o Estatuto da Criança e do Adolescente e dá outras providências. Brasília, DF: Presidência da República, [2021]. Disponível em: http://www.planalto.gov.br/ccivil_03/leis/ 18069.htm. Acesso em: 09 set. 2021.

FIGUEIRA, Márcia Luiza Machado. A revista Capricho e a produção de corpos ado-lescentes femininos. In: LOURO, Guacira Lopes, FELIPE, Jane, GOELLNER, Silva-na Vilodre. Corpo, gênero e sexualidade: um debate contemporâneo. 9. ed. Pe-tropólis: Vozes, 2013. p.124-135.

FONTANEZI, Nathalia Moretti; PEREIRA, Aline Maria Luiz. Comportamento alimen-tar de risco. In: VITALLE, Maria Sylvia de Souza et al. (org). Medicina do adolescente: fundamentos e prática. Rio de Janeiro: Atheneu, 2019. p.401-406.

GOELLNER, Silvana Vilodre. A produção cultural do corpo. In: LOURO, Guacira Lopes, FELIPE, Jane, GOELLNER, Silvana Vilodre. Corpo, gênero e sexualidade: um debate contemporâneo. 9. ed. Petropólis: Vozes, 2013. p. 30-42.

GOELLNER, Silvana Vilodre. A educação dos corpos, dos gêneros e das sexualidades e o reconhecimento da diversidade. Cadernos de Formação RBCE, v.1, n.2, p. 71-83, Mar. 2010. Disponível em: http://revista.cbce.org.br/index.php/ cadernos/article/view/984/556. Acesso em: 12 jul. 2021.

HALL, Stuart. Cultura e Representação. Rio de Janeiro: Ed.PUC-Rio: Apicuri, 2016. 260 p. 
ANDRADE, Sandra dos Santos. Mídia impressa e educação de corpos femininos. In: LOURO, Guacira Lopes, FELIPE, Jane, GOELLNER, Silvana Vilodre. Corpo, gênero e sexualidade: um debate contemporâneo. 9. ed. Petropólis: Vozes, 2013. p. 109-123.

LAMBERT, Tarla. '50 Worst beach bodies' was an actual headline in 2021 . Howen's Agenda. 2021. Disponível em: https://womensagenda.com.au /life/50-worst-beach-bodies-was-a-legitimate -headline-in-2021-we-need-to-do-better/. Acesso em: 03 ago. 2021.

LOURENÇO, Tainá. Cresce em mais de $140 \%$ o número de procedimentos estéticos em jovens. Jornal da USP. 2021. Disponível em: https://jornal.usp. $\mathrm{br} /$ ciencias/cresceu-mais-de-140-o-numero-de-procedimentos-esteticos-em-jovens-nos-ultimos-dez-anos/\#: :text=O\%20Brasil\%20\%C3\%A9\%20I\%C3\%ADder\%20mundial,at\%C3\%A9\%2018\%20anos\%20de\%20idade. Acesso em: 13 set. 2021.

NASCIMENTO, Letícia. Transfeminismo. Editora Jandaíra, 2021. 118p.

ORGANIZAÇÃO DAS NAÇÕES UNIDAS. Juventude no Brasil. ONU. 2021. Dispo-nível em: https://pt.unesco.org/fieldoffice/brasilia/expertise/youth-brasil. Acesso em: 09 set. 2021.

PELÚCIO, Larissa. Desfazendo o gênero. In: MISKOLCI, Richard, JÚNIOR, Jorge Leite. Diferenças na educação: outros aprendizados. São Paulo: EdUFSCar, 2014. p. 97-147.

TOVAR, Virgie. Meu corpo, minhas medidas. São Paulo: Primavera Editorial, 2018. 128p.

WOLF, Naomi. O Mito da Beleza: como as imagens de beleza são usadas contra as mulheres. 11. ed. Rio de Janeiro: Rosa dos Tempos, 2020. 490 p.

VARGAS, Juliana Ribeiro de. Elas querem ser Pocahontas!: o funk ostentação e a juventude feminina contemporânea. Rev. Diversidade e Educação, v.4, n.7, p. 10-17, jan./jun. 2016. Disponível em: https://sexualidadeescola.furg.br/images/ REVISTAS/Revista-7.pdf. Acesso em: 30 set. 2021.

VARGAS, Juliana Ribeiro de. Culturas Juvenis Contemporâneas: produções sobre o tema. In: RIBEIRO, Paula Regina Costa; MAGALHÃES, Joanalira Corpes (org). Debates contemporâneos sobre Educação para a Sexualidade. 2017. Disponível em: http://repositorio.furg.br/bitstream/handle/1/7097/debates_contemporaneos_educacao_sexualidade.pdf?sequence=1. Acesso em: 11 jul. 2021. 


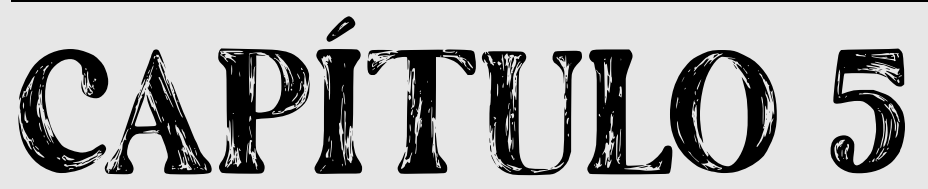

\section{TERRITÓRIOS \\ SUBJETIVOS DE UM COLETIVO \\ DE JOVENS NA PERIFERIA DE PORTO ALEGRE}

Bruna Molina Leal Rosemarie Gartner Tschiedel Nair Iracema Silveira dos Santos 
O desenvolvimento das cidades brasileiras promoveu diversos modos de sociabilidade e de subjetivação entre as pessoas, considerando as desigualdades decorrentes da configuração da ocupação do espaço público. As relações dos jovens com as cidades se constituem na multiplicidade de cenários e de elementos que compõem subjetividades juvenis. Tais elementos podem ser de diversas ordens e diferentes arranjos - sociais, políticos, econômicos, culturais, ancestrais, etc. Esta perspectiva da multiplicidade referenciada em autores como Deleuze e Guattari (1995) tem sido suporte para derivações nos modos de pesquisar experiências das juventudes, exercício que tentamos empreender neste e em outros trabalhos.

A produção aqui apresentada é parte de uma pesquisa ${ }^{1}$ realizada durante o mestrado da primeira autora e, considerando a organização da obra proposta, a análise contempla um recorte de dados da pesquisa ${ }^{2}$. Ao acompanhar experiências juvenis em uma comunidade periférica da cidade de Porto Alegre-RS, problematizou-se a construção de territórios subjetivos, no contexto de um coletivo juvenil formado, inicialmente, por relações de amizade entre jovens da comunidade.

Este grupo queria se tornar uma referência na comunidade jovem da llha da Pintada, pensando uma organização abrangente, de forma a estimular experiências participativas. Com este intuito de mobilização na comunidade, o coletivo, autointitulado "Colaí, Movimento de Cultura", constituiu-se de maneira a ocupar a praça de modos distintos, promovendo atividades de lazer, esporte e cultura. A Praça Dr. Salomão Pires Abraão, apesar de sua posição central, ao lado da Escola Estadual Almirante Barroso, era referenciada por moradores como espaço de "tráfico de drogas" e de circulação de "pessoas suspeitas" e estava em processo de abandono. Assim, ao organizar ações como o "Colaí na Praça”, o "Colaí

$1 \quad$ Aprovada no Comitê de Ética do Instituto de Psicologia da Universidade Federal do Rio Grande do Sul e posteriormente com as assinaturas de Termos de Consentimento por todos os participantes.

2 Em decorrência ao trabalho apresentado no VI Simpósio Internacional sobre a Juventude Brasileira, realizado de 10 a 12 de setembro de 2015 no Rio de Janeiro, estando disponíveis nos Anais do evento no site: http://www.jubra.nipiac.psicologia.ufrj.br/images/pdf/Caderno_de_ Resumos.pdf 
no Cinema”, o "Colaí na Pelada", esse coletivo passa a transformar os espaços de convivência comunitária. O próprio Colaí adota para isso práticas de autogestão, de maneira a se organizar e promover as atividades congregando interesses particulares com os da comunidade.

No processo de pesquisar com este coletivo, utilizou-se uma articulação metodológica entre princípios etnográficos e uma ética cartográfica, estando junto, acompanhando processos, participando e observando. A pesquisadora participou de reuniões de planejamento e de várias atividades desenvolvidas com a comunidade no ano de 2014 e 2015 . Foram produzidos diários de campo com base nos registros de conversas presenciais, digitais, de pautas e diálogos e nos documentos produzidos pelo coletivo. Ao longo do período em que participou das atividades, foram elaboradas pequenas análises, discutidas em reuniões do coletivo, a partir não só de questões propostas no projeto, mas também de questões derivadas e criadas no diálogo com os participantes da pesquisa. A problematização sobre "como o Colaí vinha construindo territórios subjetivos" se abriu em outras perguntas operadoras de análise: o que emerge como questão para o Colaí? O que mobiliza as suas ações? Como o Colaí tem se constituído como coletivo? Como os integrantes dialogam e se posicionam entre jovens e com instituições da comunidade e do poder público?

Muitas de suas ações e práticas permitiram que o grupo de amigos se apresentasse como um coletivo, discutido na pesquisa desenvolvida como um plano de relações subjetivas, para além de um agrupamento de pessoas. Escóssia (2014) nos ajuda na compreensão do coletivo para além da coletividade e da ação coletiva, ao abordá-lo como plano relacional, que se move entre formas (de certa organização da realidade ou da face instituída) e forças (dos deslocamentos, tensões e variações). Nessa perspectiva do coletivo como um plano relacional, impessoal, o que se busca conhecer são os movimentos e repousos, os acontecimentos que acionam a produção de subjetividades e constituem certo “coletivo de jovens em ação". 
Para entender a construção de territórios subjetivos, utilizamos esse conceito a partir das contribuições de Guattari e Rolnik (2005) que o concebem tanto como o espaço vivido, quanto ao modo como os sujeitos circulam, se inserem e criam estratégias de relações e de vida nos tempos e espaços sociais, culturais, estéticos e afetivos. Assim, neste capítulo propomos discutir a construção de territórios subjetivos juvenis, recortando especialmente um dos eventos promovidos pelo Colaí. A partir desta análise, é possível sentir algumas tensões observadas entre as estratégias adotadas pelo Colaí no momento da pesquisa: de um lado, um modo burocrático e econômico na atenção às prescrições do poder público na busca por financiamento; de outro, um modo inventivo que aciona encontros mediados por afetos, pela arte e pela cultura.

\section{A CONSTRUÇÃO DOS INTERCESSORES}

De modo a problematizar a construção de territórios subjetivos em um coletivo de jovens, foi necessário atentar para as próprias implicações das autoras, de maneira a buscar instrumentos de ação e intercessão que permitissem a análise durante os processos.

O essencial são os intercessores. A criação são os intercessores. Sem eles não há obra. [...] Eu preciso de meus intercessores para me exprimir, e eles jamais se exprimiriam sem mim: sempre se trabalha em vários, mesmo quando isso não se vê. (DELEUZE, 1992, p. 156).

Nesse sentido, trabalhamos neste capítulo com dois intercessores conceituais - território subjetivo e coletivo - de modo a utilizá-los como ferramentas teórico - técnicas e ético-políticas como propõem Costa, Perico e Souza (2019).

E para pensar o território subjetivo, primeiro precisamos retomar a origem da palavra território, territorium, sendo uma palavra em latim que deriva do vocábulo terra e significa pedaço de terra apropriado. Pensar sobre território é extremamente complicado porque traz em si múltiplos significados, nas diversas áreas de conhecimento. No debate da geografia crítica, Milton Santos (1994) concebe o uso do território como um objeto de análise social, afinal, as formas do território 
trazem consigo objetos e ações da comunidade que o habita, configurando-se num espaço humano. Ao mesmo tempo, apresenta o espaço como realidade social, em que cada comunidade ocupa seu espaço de acordo com as funcionalidades atribuídas a ele pelo contexto cultural, construindo usos através do tempo (SANTOS, 2006).

Em pesquisa realizada na região das ilhas em Porto Alegre, Carrion e Costa (2010) destacam que trabalhar com a noção de território, a partir de bases geográficas, não é possível nesta região. Devido à grande movimentação de pessoas entre as ilhas, é importante considerar o território da região como uma rede de relações sociais. Araújo (2011) assume que o cenário de uma cidade seria a "materialidade da vida humana", tendo em vista o sujeito possuidor de direitos, válido e participativo junto à construção de uma realidade comum, pública, compartilhada entre os sujeitos. Assim, seria possível pensar no espaço público da cidade como arenas em que as diferenças são publicizadas e disputam espaço no discurso vigente (LEITE, 2002). Neste sentido, Guattari (1985) apresenta a necessidade de distinção entre os conceitos de espaço e território, já que muitas vezes estão associados entre si. Para ele,

[...] os territórios estariam ligados a uma ordem de subjetivação individual e coletiva e o espaço estando ligado mais às relações funcionais de toda espécie. O espaço funciona como uma referência extrínseca em relação aos objetos que ele contém. Ao passo que o território funciona em uma relação intrínseca com a subjetividade que o delimita. (GUATTARI, 1985, p. 110).

É possível, assim, associar os territórios relativos ao espaço vivido, em que os seres existentes os articulam e os delimitam de acordo com o sistema em que se sentem "em casa" (GUATTARI; ROLNIK, 2005). Esses territórios são resultados de subjetivação, projetos e representações que influenciam os comportamentos, ditam os investimentos, são determinados pelos contextos sociais, culturais, estéticos e cognitivos em que a pessoa está associada. Ainda, é importante delimitar o conceito de subjetividade como um "conjunto das condições que torna possível que instâncias individuais e/ou coletivas estejam em posição de emergir em território existencial autorreferencial" (GUATTARI, 1992, p. 19). 
Ferreira Neto (2011), ao abordar o território subjetivo, percebe que a subjetividade pode ser entendida como emergência histórica de processos, não determinados pelo social, mas em conexão com os demais processos sociais, culturais, econômicos, tecnológicos, midiáticos, urbanos, ecológicos, que participam de sua constituição e de seu funcionamento. Referenciadas nos escritos de Guattari e Rolnik (2005), tomamos como intercessor o conceito de território subjetivo, que deve ser entendido como muito mais que um conceito voltado a uma lógica dura, representacional, e sim como um construto que nos leva a problematizar a produção de múltiplas subjetividades que são afetadas pelas experiências e situações vividas nos espaços, tempos e relações estabelecidas.

A constituição de territórios subjetivos, portanto, é efeito de movimentos de territorialização e de desterritorialização, processo em que subjetividades, ou seja, modos de ser e estar no mundo, se atualizam. No momento em que consideramos a subjetividade em movimento, sendo afetada pelos fluxos que perpassam os territórios fixados, promovendo desterritorializações e reterritorializações constantes, concebemos a subjetividade sob uma face sensível, quase como mapas de sensações, não redutível ao indivíduo, mas sim composição de fluxos, de encontros envolvendo pessoas, coisas, discursos, ações, experiências, elementos materiais e imateriais.

Assim, analisamos o Colaí como um grupo de jovens em ação, em determinada comunidade, que se faz coletivo, constituindo e/ou experimentando territórios, posições-composições que dizem da circulação de jovens participantes e dos encontros que agenciam. Marcado por processos de subjetivação que permitem compreender as constituições dos sujeitos a partir dos saberes e poderes constituídos, o grupo de jovens surge no espaço entre as dimensões individuais e sociais, em processo de construção constante, produzindo novos saberes e poderes (BARROS, 2007).

Concebendo que a subjetividade "não se situa no campo individual, seu campo é o de todos os processos de produção social e material" (GUATTARI, 1986, p. 32), é possível perceber a presença de atores políticos, econômicos, 
tecnológicos, ecológicos e semióticos nessa dimensão subjetiva, destacando movimentos de desindividualização, rompendo com a ideia de que a subjetividade é individual, de pessoa a pessoa. E esses processos de subjetivações são marcados pela disputa de pluralidade de forças, pela multiplicidade e polivocidade, tornando-se impessoal e coletivo. Assim, este coletivo pode ser compreendido para além da coletividade localizada no agrupamento de pessoas, conforme destacado por Guattari (1990):

[...] o termo coletivo deve ser entendido aqui no sentido de uma multiplicidade desenvolvendo-se para além do indivíduo, do lado do socius, como também aquém da pessoa, do lado das intensidades preverbais, revelando mais uma lógica dos afetos que de uma lógica de conjuntos de bens circunscritos. (GUATTARI, 1990, p. 8).

Maheirie et al (2012) percebem que coletivos são diferentes entre si devido às diversas possibilidades de constituição, conceituando-os como "configurações reais e/ou virtuais que sujeitos estabelecem em determinado contexto concreto, a partir de tempos e espaços que se definem em torno de um tema ou questão" (MAHEIRIE et al, 2012, p. 152). E assim, o próprio espaço ocupado apresenta também a característica de ser lócus da produção de subjetividade para os jovens (ZANELLA et al, 2012). Diógenes (2003) aponta que os corpos juvenis reinventam os usos dos espaços constantemente, tomando a esfera pública como palco e lugar de experiências múltiplas, em que o movimento é uma constante. Essas ações coletivas juvenis buscam desestabilizar as forças disciplinares instituídas, abrindo diversas possibilidades, pulverizando novas conexões, novos desejos e valores, promovendo um palco público e privado para as suas experimentações.

Assim, esse coletivo deve ser concebido para além de uma visão dicotômica do indivíduo-sociedade, a partir da possibilidade de coexistência e indissociabilidade entre a dimensão individual e social nos processos de subjetivação. Escóssia (2014) discute sobre esse conceito a partir da percepção de que só se conhecem os objetos quando estes estão em relação, concebendo-o em uma rede coletiva híbrida, mutante, heterogênea, plural, movente e diferenciada. Esse 
coletivo é distinto de uma coletividade, de uma ação coletiva, de uma dimensão social, sendo um plano de forças em que sempre estão ocorrendo relações, num processo de subjetivação coletiva, sem ser somente individual ou social (ESCÓSSIA; KASTRUP, 2005).

Ao conceber o coletivo como um plano produtor de mundo e de sentido, este surge como um plano ético-político, tornando-se uma política do comum e das multidões, em que se destaca a constituição de um mundo comum como um processo de composição de relações e de conexões, constituído pouco a pouco a partir de experiências coletivas. Este coletivo pode ser visto nos grupos e na comunidade assim como no plano dos afetos impessoais e no diagrama de forças. Pode ser considerado como um campo de singularidades e intensidades, como uma dimensão transindividual, como plano não totalizável, não substancial e não representacional, como um campo de cruzamento de crenças e desejos, forças que esculpem e modelam o social, e ainda como plano de coengendramento e de criação do indivíduo-meio e do sujeito-mundo, indicando um caminho para a superação das visões dicotômicas.

Escóssia (2009) propõe pensarmos em uma política do coletivo como "uma experiência coletiva permanente de problematizações, identificações de perigos e escolhas ético-políticas", de maneira a perceber este coletivo no plano de imanência de produção de subjetividade nos territórios subjetivos. A noção de agenciamento coletivo de enunciação (DELEUZE; GUATTARI, 1995) parece dar suporte a essa política do coletivo. Não se trata de coletividade, mas sim da composição entre elementos heterogêneos, encontros entre corpos de natureza diversa, materiais e imateriais, diferentes máquinas de expressão que se agenciam. Operar com esse intercessor coletivo, problematizando a construção de territórios subjetivos em práticas de um grupo de jovens, permitiu analisar diversas particularidades e singularidades do Colaí, de maneira a buscar o desenho da composição das forças, dos movimentos e dos repousos em ação. 


\section{PRODUZindo ENCONTROS COM COLAÍ, MOVIMENTO DE CULTURA}

Para melhor apresentar alguns resultados, é importante contextualizar o território da Ilha da Pintada e alguns entrecruzamentos do "Colaí, Movimento de Cultura". Sendo uma ilha, a comunidade da llha da Pintada possui características particulares quanto a sua posição periférica na cidade de Porto Alegre. Estando ligada ao centro apenas pela água, para chegar na cidade é necessário utilizar a estrada que leva à Zona Norte da capital gaúcha, com apenas a opção de uma linha de ônibus de transporte público que faz este trajeto.

Quando analisamos as políticas públicas no Arquipélago, encontramos espaços escolares compartilhados, com uma única escola municipal de Educação Infantil, duas escolas públicas de Ensino Fundamental, uma escola estadual de Ensino Médio noturno. Com isso, as trajetórias dos jovens da comunidade acabam por se cruzarem frequentemente, tendo relações sociais próximas e muitas vezes com grandes laços familiares na comunidade.

Ainda, é necessário destacar que as reuniões do Colaí ocorriam em um dia da semana à noite, no espaço reservado junto à Subprefeitura da Região das Ilhas para atividades da comunidade. Os participantes passavam o dia trabalhando e/ou estudando, assim as reuniões ocorriam às $22 \mathrm{~h}$ da noite, momento que todos tinham disponível para se encontrarem e organizarem as ações propostas na comunidade. Durante o período da pesquisa, foram realizados os eventos "Colaí na Praça", com ocupação da praça com música, o "Colaí no Cinema", com a promoção de uma sessão de cinema no final da tarde e o "Colaí na Pelada", sendo este último um campeonato de futebol utilizando a quadra da escola ao lado da praça. Ao realizar intervenções culturais na comunidade, o coletivo buscava promover bandas compostas por membros da llha ou de outros locais de Porto Alegre para tocar, filmes brasileiros e até a convivência durante o esporte.

Era nessas reuniões noturnas e na organização dos eventos que a dimensão coletiva ganhava evidência, em que as forças criativas emergiam, produzindo novos sentidos e ações, tensionando o grupo para além do cumprimento de tarefas, estando aberto às vontades individuais e aos acontecimentos, permeável 
às linhas de subjetivação, possibilitando a produção de novos territórios subjetivos em que se expressam os interesses e os afetos dos participantes. O Colaí teve diversas discussões quanto à organização do coletivo e o seu financiamento para a promoção dos eventos, buscando parcerias com serviços locais para a execução dos eventos. O próprio grupo se auto-organizava contando com os laços sociais que possuem com a comunidade e conversas com as lideranças locais.

Buscando reconhecimento na comunidade, desenvolviam vários eventos, pensando no que gostariam de participar e de que maneira poderiam ocupar o espaço da comunidade, dando destaque aos talentos, habilidades e potencialidades dos jovens da llha, com atividades de lazer, cultura e esporte. Para isso, era necessário participar também dos espaços democráticos locais, como os Fóruns Regionais do Orçamento Participativo que, muito mais que apenas determinar a destinação de verbas públicas, era um espaço institucional regional quinzenal de encontro de lideranças da comunidade. Mesmo valorizados e reconhecidos como participantes desses encontros, os membros que participavam das reuniões sentiam que eram colocados ainda em um lugar de ter muito a aprender, de ter que provar o seu valor, muitas vezes comparecendo com vários membros para ter maior credibilidade.

Aqui, cabe destacar as contribuições de Barbalho (2012) que observou que o programa de Orçamento Participativo tem atuado na linha da frente entre políticas democratizantes e lógicas neoliberais. Enquanto a primeira é pautada pela participação das comunidades no desenvolvimento de políticas públicas de cultura, a segunda é marcada pela transformação do cidadão em consumidor de cultura, estabelecendo um mercado que busca lucrar a partir das expressões culturais. Ao analisar as ações culturais promovidas pelo Colaí e as reuniões de organização, percebe-se essas tensões entre um modo burocrático e econômico na atenção às prescrições do poder público na busca por financiamento; e um modo inventivo que aciona encontros mediados por afetos, pela arte e cultura. Elaboramos a figura 1 de modo a exemplificar algumas questões dessa tensão. 
Figura 1 - Tensões

\section{Relação com o Centro Administrativo Regional}

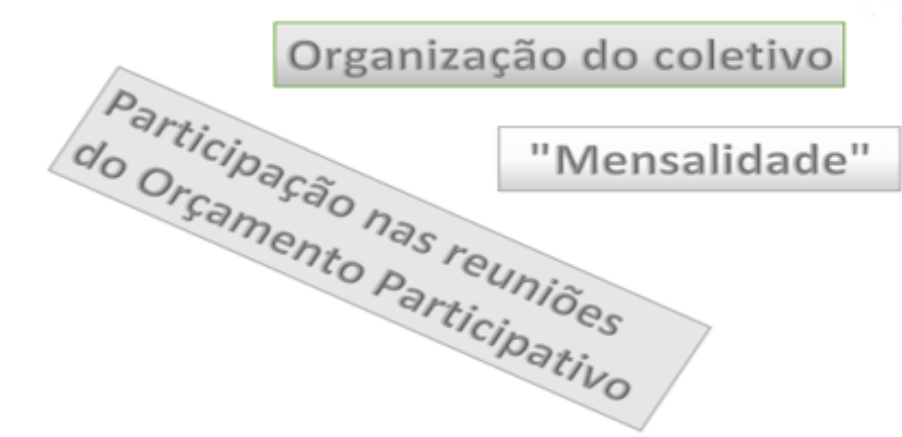

Conflito com disputas políticas partidárias locais

\section{Novos projetos}

\section{Divulgação dos trabalhos}

\section{Novos encontros}

\section{Escolhinha defutebol}

Envolvimento com

a comunidade

Novos parceiros
Doações

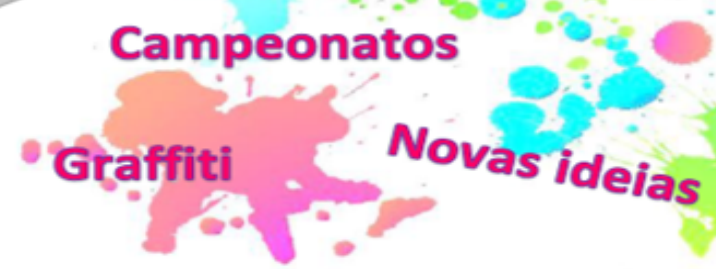

Fonte: Desenvolvimento próprio.

Ao analisar a figura acima, podemos perceber algumas das questões enfrentadas pelo Colaí. Ao mesmo tempo em que tentam se estabelecer na região, participando da vida política da comunidade, a fim de ganhar visibilidade, enfrentam questões como a organização do coletivo, a burocratização do movimento e, ainda, a necessidade de obter doações ou mesmo a criação de uma mensalidade para financiar as ações propostas. Este lado mais cinza, que chamamos de mais burocrático, conflitua com as propostas movidas pelos afetos, pelo esporte, pela arte, pela cultura que promovem novas ideias, novos projetos, novas possibilidades de divulgação do talento local, contando com o envolvimento da comunidade jovem e a promoção de uma escolinha de futebol, a ocupação da praça com música, grafite, campeonatos de esportes, entre outros.

Nesse sentido, retomamos o trabalho de Coelho e Durão (2012) quanto à criação do Grupo Cultural AfroReggae no Rio de Janeiro, que surgiu como uma reatualização de movimentos sociais a fim de promover atividades culturais de enfrentamento à violência, como alternativa ao tráfico de drogas. Esse Grupo 
promoveu a construção de um senso de responsabilidade para com os demais jovens da comunidade e, ao promover eventos, os projetos eram vinculados a motivações pessoais, muito mais que à ênfase política e militante, associando o movimento social a uma possibilidade de profissionalização. Dessa maneira, o Colaí, percebendo o seu lado inventivo, acaba por promover também uma possibilidade de profissionalização. Podemos trazer mais exemplos quando analisamos mais profundamente um dos eventos elaborados pelo Colaí, o "Colaí na Praça". Para ilustrar, apresentamos as figuras 2 e 3 para problematizar o evento citado.

Figura 2 e 3 - Colaí na Praça

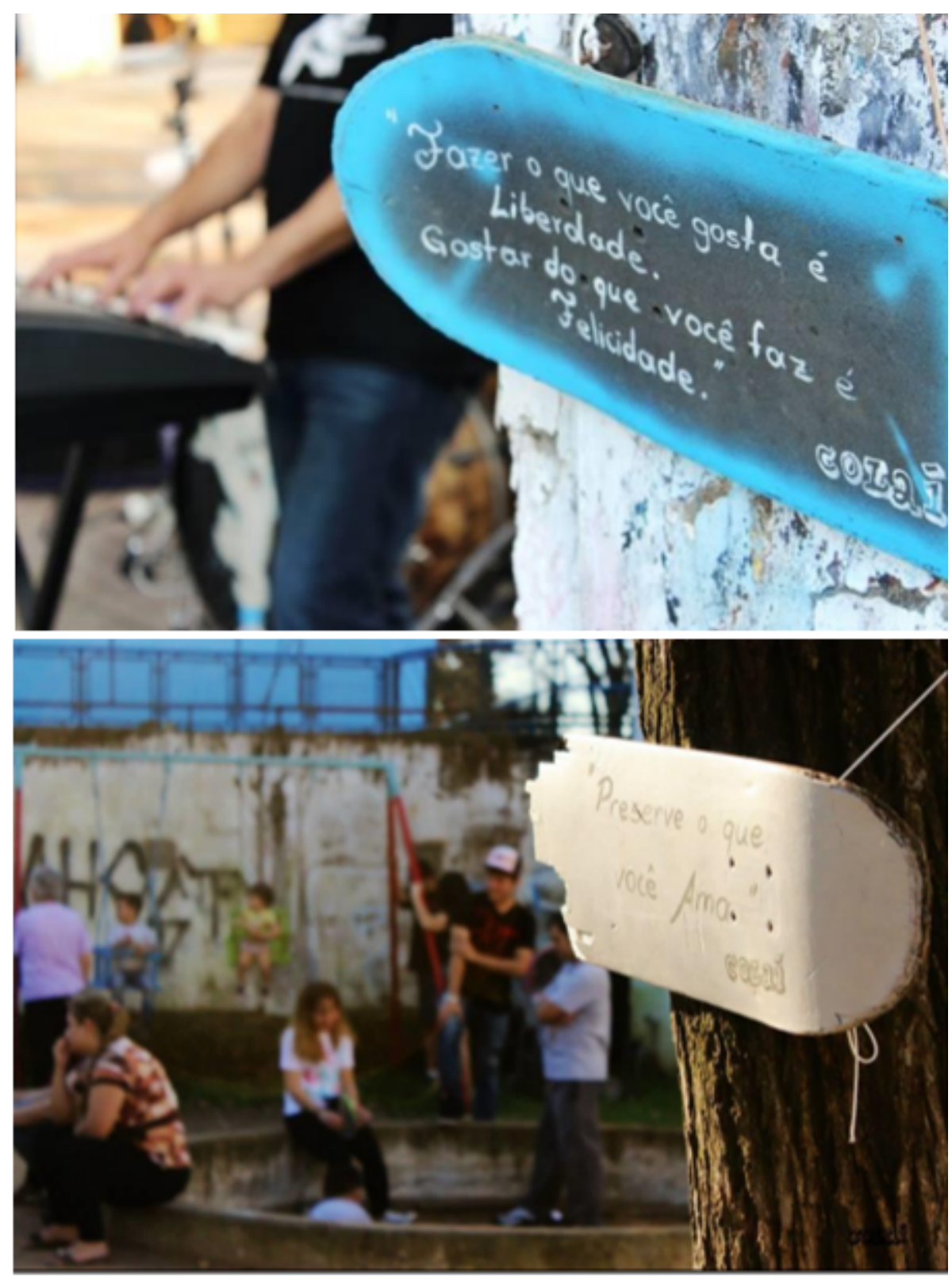

Fonte: Facebook - página Colaí Movimento de Cultura. 
Estas fotos foram tiradas em eventos do Colaí na Praça no período da pesquisa. O Colaí na Praça, principal ação do coletivo, era organizado aos domingos à tarde, com o convite de uma banda local, da própria comunidade ou de outra comunidade de Porto Alegre, para tocar na praça de maneira a promover convivência e ocupar o espaço. Nesses dias, com o evento marcado apenas em dias sem chuva, sempre compareciam muitas pessoas, famílias que levavam as suas crianças na pracinha, formavam-se rodas de chimarrão e era disponibilizada bola pelo coletivo para quem quisesse jogar vôlei. Observamos que, ao organizar a praça para atividades culturais, o Colaí mobiliza diversos segmentos da comunidade, transformando-a em um espaço de convivência.

Outro detalhe a ser ressaltado é que as fotos destacam frases motivacionais pintadas em pranchas de skates quebrados. Uma das primeiras ações do Colaí, quando o grupo de amigos começou a se organizar e se mobilizar politicamente, foi quando se mobilizaram para solicitar uma rampa de skate na praça, assim os skates ficaram como símbolo do histórico do grupo. Muito se modificou desde a sua formação até a composição durante a pesquisa, e ainda após a pesquisa, tendo os participantes uma facilidade de entrar e sair conforme o contexto da sua composição e a vida pessoal de seus integrantes. Durante a pesquisa, o grupo se modificou constantemente, com ingressos e saídas, devido a compromissos pessoais. Atualmente, o Colaí tem uma composição totalmente diferente da que tinha quando a pesquisa foi realizada, trabalhando mais com apoio escolar e tendo construído uma biblioteca comunitária, considerando o perfil do grupo que o compõe e as necessidades prementes da comunidade.

O coletivo vai modulando e dobrando os territórios constituídos, desmanchando-os e construindo outros, conforme as variações nos encontros, nos acontecimentos, nos tempos e espaços e na abertura de novos diálogos entre jovens e entre as demandas produzidas no próprio coletivo e na comunidade. Se o fator financeiro os joga para um modo capital-empresa, os encontros e experimentações com as artes e com culturas diversas os posiciona como inventores de mundos. Mas este modo também se faz nos preceitos morais expressos e apreendi- 
dos nas várias instituições que compõem suas relações - família, escola, igreja - como jovens que podem ser e/ou são visualizados como "modelos do bem".

\section{MAIS ALGUMAS REFLEXÕES}

Esta pesquisa nos levou a problematizar a construção de territórios subjetivos a partir de atividades promovidas por um coletivo juvenil em uma comunidade periférica da cidade de Porto Alegre. Pudemos participar das reuniões do Colaí, das reuniões entre os membros do coletivo e os representantes políticos da comunidade, do planejamento e do preparo das ações, bem como das próprias atividades propostas pelo Colaí pela comunidade: a participação do carnaval de rua, a concepção de uma escolinha de futebol, a ocupação da praça com música e esporte, a ação de grafiteiros convidados para alegrar a praça, campeonatos de futebol e de vôlei com narração dos participantes. Ao desenvolver estas atividades e eventos, promovem-se novas oportunidades e possibilidades de interação, de maneira a produzir processos de subjetivação frente às relações sociais da comunidade.

Nesse sentido, destacam-se as particularidades do território da llha da Pintada em que a rede de relações sociais é muito compartilhada e, com isso, a atuação do coletivo chega a diversos jovens. Atualmente, o Colaí é composto por jovens que participaram dos eventos e ações do grupo e decidiram seguir com o trabalho realizado, considerando a importância que os eventos tiveram para eles. Isso demonstra o espaço que o coletivo passou a ocupar junto à população jovem da comunidade e a relevância de suas ações, em que opções de cultura e lazer em uma comunidade periférica são escassas. A intervenção do coletivo na comunidade foi tão significativa que a sua experiência mantém a proposta do Colaí viva, mesmo com as dificuldades atuais, estando os seus integrantes atentos às demandas emergentes na população jovem para a reelaboração de novos rumos para o grupo. 
O Colaí, tendo uma constituição livre que permite a sua mudança constante, de acordo com os desejos pessoais e as forças atuantes, segue vivenciando conflitos quanto a sua organização e validação junto à comunidade e lideranças locais. Enquanto a sociedade busca uma forma, a fluidez presente no Colaí causa tensionamentos para uma organização. O grupo é movido por vínculos de amizade e relações com a comunidade, estando mais suscetível às forças emergentes e atravessamentos do que muitas outras organizações. Ainda, a característica de sua constituição, como um movimento jovem, faz com que nem sempre conte com o reconhecimento de sua comunidade, produzindo alguns impasses.

Mesmo com isso, o Colaí segue ativo, estando vinculado à população jovem da Ilha da Pintada, seja por conexões sociais, familiares e/ou de amizade. Em um território periférico, continuamente isolado da vida cultural da cidade, ações juvenis para a promoção desta acabam sendo muito importantes e valorizadas pela sua comunidade. Com a sua auto-organização, o Colaí mantém atividades diversas e atrativas de acordo com as necessidades presentes na região, de maneira a promover ações que façam os jovens desejarem se somar ao Colaí, ocupando os espaços com música, arte, leitura, esporte, lazer e cultura.

\section{REFERENCIAS}

ARAÚJO, Vania Carvalho de. A cidade como espaço público de educação e de afirmação da cidadania: a experiência de Vitória/ES, Brasil. RBPAE - Revista Brasileira de Política e Administração da Educação, v.27, n.1, p.135-148, jan./ abr. 2011.DOI: https://doi.org/10.21573/vol27n12011.19973. Disponível em: https://seer.ufrgs.br/rbpae/article/view/19973/11604. Acesso em: 14 outubro 2021.

BARBALHO, Alexandre. Política Cultural e Orçamento Participativo: ou as possibilidades da democracia cultural na cidade contemporânea. Políticas Culturais em Revista, Salvador, v. 5, n. 1, p. 156-169, 2012.DOI: https://doi.org/10.9771/ 1983-3717pcr.v5i1.6496. Disponível em: https://periodicos.ufba.br/index.php/ pculturais/article/view/6496/4543. Acesso em: 14 outubro 2021.

BARROS, Regina Benevides de. Grupo: a afirmação de um simulacro. Porto Alegre: Sulina/Editora da UFRGS, 2007. 
CARRION, Rosinha Machado; COSTA, Pedro de Almeida. Governança Democrática, Participação e Solidariedade: Entre a Retórica e a Práxis. Espacio Abierto Cuaderno Venezolano de Sociologia, Venezuela, v. 19, n. 4, p. 621-640, out./dez. 2010. Disponível em: https://www.redalyc.org/comocitar.oa?id=12216181002. Acesso em: 14 outubro 2021.

COELHO, Maria Claudia; DURÃO, Susana. Moral e emoção nos movimentos sociais: Estudo da "tecnologia social" do Grupo Cultural AfroReggae. Revista de Antropologia, São Paulo, v. 55, n. 2, p. 899-935, jul./dez. 2012. Disponível em: https://www.jstor.org/stable/43923865. Acesso em: 14 outubro 2021.

COSTA, Maico Fernando; PERICO, Waldir; SOUZA, William Azevedo de. Do dispositivo disciplinar ao dispositivo intercessor. Revista Psicologia UNESP, Assis, v. 18, n. spe, p. 161-178, dez. 2019. Disponível em: http://pepsic.bvsalud.org/pdf/ revpsico/v18nspe/v18nspea09.pdf. Acesso em: 14 outubro 2021.

DELEUZE, Gilles. Os Intercessores. In: ter Pál Pelbart. São Paulo: Editora 34, 1992.239 p.

. Conversações. Tradução: Pe-

DELEUZE, Gilles; GUATTARI, Felix. Mil Platôs: capitalismo e esquizofrenia. Vol. 2. Rio de Janeiro: Editora 34, 1995.128 p.

DIÓGENES, Glória. Itinerários de corpos juvenis, o tatame, o jogo e o baile. São Paulo: Annablume, 2003.226 p.

ESCÓSSIA, Liliana da. O coletivo como plano de criação na Saúde Pública. Interface - Comunicação, Saúde e Educação, Botucatu, v. 13, supl. 1, p. 689694, 2009. DOI: https://doi.org/10.1590/S1414-32832009000500019. Disponível em: https://www.scielo.br/j/icse/a/yMKxN8BDkcg3hdMMJR3BCvf. Acesso em 14 outubro 2021.

ESCÓSSIA, Liliana; KASTRUP, Virgínia. O conceito de coletivo como superação da dicotomia indivíduo-sociedade. Psicologia em Estudo, Maringá, v. 10, n. 2, p. 295-304, ago. 2005. DOI: https://doi.org/10.1590/S1413-73722005000200017. Disponível em: https://www.scielo.br/j/pe/a/q5rCtwtDCZgpC84gJTcKY8v. Acesso em 14 outubro 2021.

ESCÓSSIA, Liliana da. O coletivo como plano de coengendramento do indivíduo e sociedade. São Cristóvão: Editora UFS, 2014. 
FERREIRA NETO, João Leite. Psicologia, Políticas Públicas e o SUS. São Paulo: Escuta; Belo Horizonte: FAPEMIG, 2011.

GUATTARI, Félix. Espaço e Poder: a criação de territórios na cidade. Espaços \& Debates - Revista de Estudos Regionais e Urbanos, São Paulo, v. 5, n. 16, p. 109-120, 1985.

GUATTARI, Felix. As três ecologias. Campinas: Papirus, 1990.

GUATTARI, Felix. Les annés d'hiver: 1980-1985. Paris: Bernard Barrault, 1986.

GUATTARI, Félix. Caosmose: um novo paradigma estético. São Paulo: Editora 34, 1992.

GUATTARI, Félix; ROLNIK, Suely. Micropolítica: cartografias do desejo. Petrópolis: Editora Vozes, 2005.

LEITE, Rogerio Proença. Contra-usos e espaço público: notas sobre a construção social dos lugares na Manguetown. Revista Brasileira de Ciências Sociais, v. 17, n. 49, p.115 -134, jun. 2002. DOI: https://doi.org/10.1590/ S0102-69092002000200008. Disponível em: https://www.scielo.br/j/rbcsoc/a/ v6ync4yt8tMpKWYRrvTpR5p. Acesso em: 14 outubro 2021

MAHEIRIE, Kátia; HINKEL, Jaison; GROFF, Apoliana R.; MULLER, Flora L.; GOMES, Marcela de A.; GOMES, Allan. Coletivos e relações estéticas: alguns apontamentos acerca da participação política. In: MAYORGA, Claudia; CASTRO, Lucia Rabello de; PRADO, Marco Aurélio Maximo (org.). Juventude e a experiência da política no contemporâneo. Rio de Janeiro: Contra Capa, 2012. P. 143-168.

SANTOS, Milton. A Natureza do Espaço: Técnica e Tempo, Razão e Emoção. São Paulo: Editora da Universidade de São Paulo, 2006.

SANTOS, Milton. O Retorno do Território In: SANTOS, Milton; SOUZA, Maria Adélia Aparecida de; SILVEIRA, Maria Laura (org). Território: globalização e fragmentação. São Paulo: Hucitec, 1994. P.15-20.

ZANELLA, Andrea Vieira; FURTADO, Janaina Rocha; ASSIS, Neiva de, BUENO, Gabriel; LEVITAN, Déborah. (2012). Jovens na cidade: arte, política e resistências. In: MAYORGA, Claudia; CASTRO, Lucia Rabello de; PRADO, Marco Aurélio Maximo (org.). Juventude e a experiência da política no contemporâneo. Rio de Janeiro: Contra Capa, 2012. 


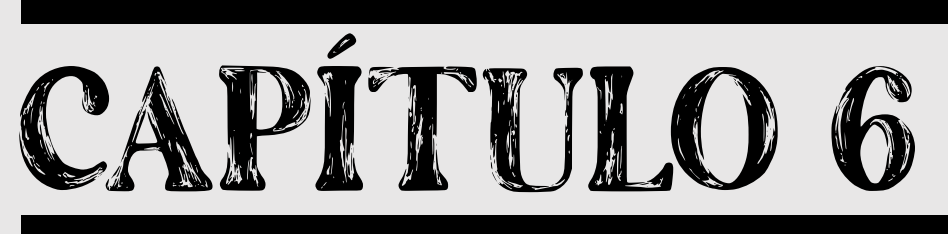

\section{A TERRITORIALIZAÇÃO JUVENIL NO/DO PARQUE AMBIENTAL IPIRANGA EM ANÁPOLIS (GO) ${ }^{1}$}

Jefferson Dias Andrade de Jesus

Mary Anne Vieira Silva Rafael Ribeiro dos Santos

$1 \quad \mathrm{O}$ artigo é resultado de reflexões voltadas às pesquisas de mestrado de Jefferson Dias Andrade de Jesus (Os jovens, o futebol e a identidade: uma análise dos torcedores de equipes futebolísticas de Anápolis/GO) e Rafael Ribeiro dos Santos (Cotidianos culturais em trânsito: uma análise do processo de (re)territorialização dos jovens migrantes universitários em Anápolis-GO); ambas estão associadas diretamente ao projeto de pesquisa "Linguagens urbanas: os jovens, suas espacialidades e redes de sociabilidade em Anápolis-GO", coordenado pela Profa. Dra. Mary Anne Vieira Silva (PPGTECCER/UEG), aprovado junto a Pró-Reitoria de Pesquisa e Pós-Graduação (PrP) da Universidade Estadual de Goiás (UEG). 


\section{INTRODUÇÃO}

No presente capítulo objetiva-se discutir os processos de territorializações ocorridas pelos jovens no Parque Ambiental Ipiranga, situado na cidade de Anápolis, Goiás (GO). Para tanto, a priori, trataremos dos conceitos de território, territorialidade e territorialização/apropriação no espaço urbano, a partir das contribuições de Raffestin (1993); Haesbaert (1997; 2003; 2004); Souza (2000; 2002); e Gottmann (2012).

Entendemos que a pluralidade teórica exige diferenciações interpretativas, logo, na primeira parte do texto, primamos, por meio desses autores, garantir a discussão das concepções plurais e teórico-conceituais. Na segunda, concatenamos os resultados empíricos às questões conceituais, para posteriori entender o processo de territorialização dos jovens no referido parque, através de procedimentos metodológicos pertinentes para o entendimento das múltiplas realidades assistidas e vivenciadas no local. E por último, as considerações finais da reflexão sobre os usos dos jovens do/no espaço público anapolino.

No que tange a investigação, in loco, é mister considerar que o Parque Ambiental Ipiranga (ou mesmo Parque Ipiranga, como é comumente chamado) insere-se em uma área de intensa especulação imobiliária e conta com a presença de vários equipamentos e prestação de serviços, fatores que impulsionam a fragmentação/segregação socioespacial, tratada por territorialidade. Esse local é bem frequentado por parte significativa dos moradores e de turistas que visitam a cidade de Anápolis, ver ilustração 01. 
Ilustração 01: Fotografia - Parque Ambiental Ipiranga, Anápolis (GO)

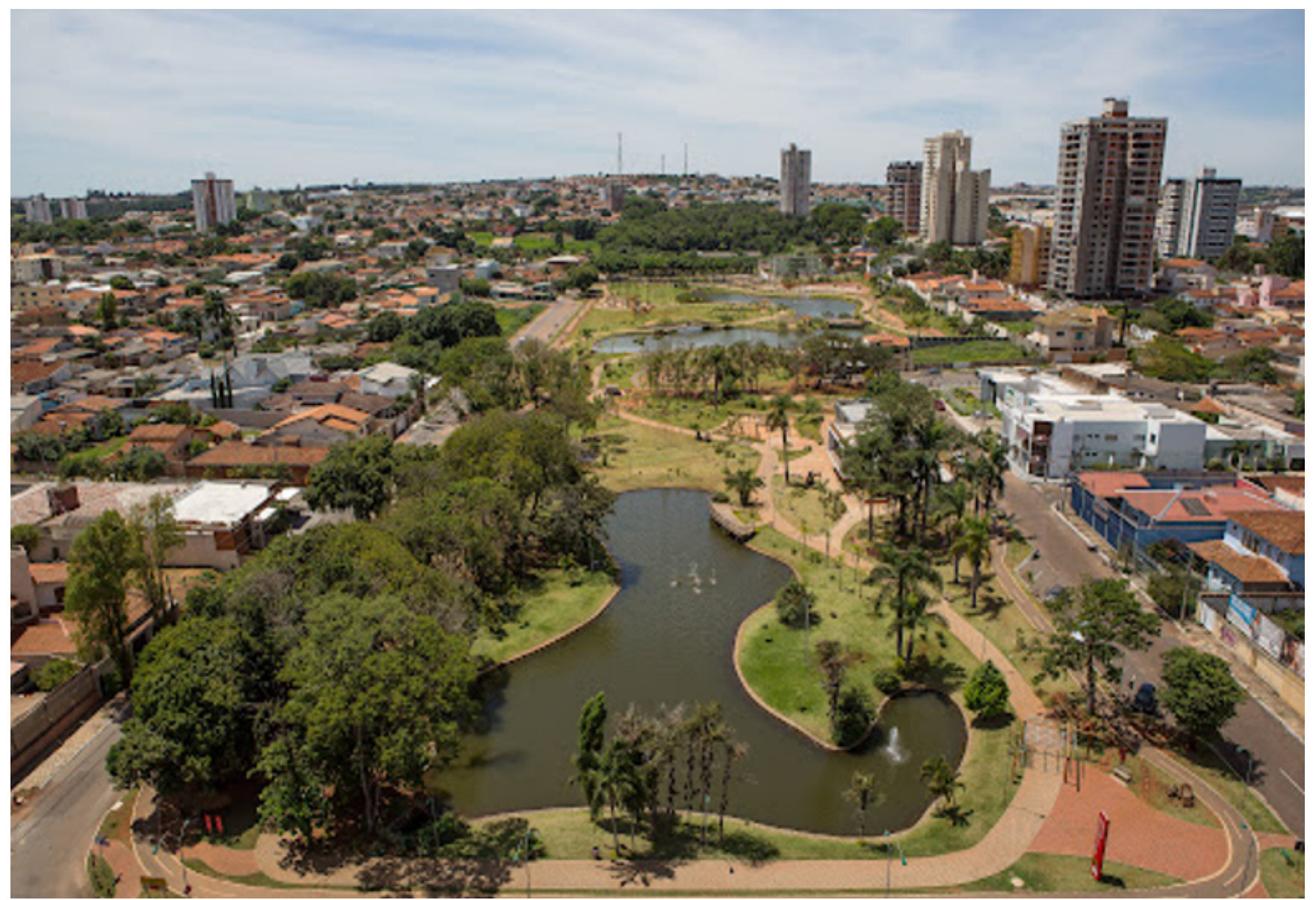

Fonte: Viva Anápolis (2016). Disponível em: http://vivaanapolis.com.br/parques-valorizamregioes-em-ate-300/. Acesso em: 20 out. 2021.

São diversos motivos que nos despertam para o presente estudo. A inquietação liga-se as experiências vivenciadas nos espaços públicos urbanos para lazer e outros usos ${ }^{1}$, esses últimos promovem várias formas de territorializações. Em sua forma-urbana paisagística, o Parque traduz a lógica do planejamento, intrinsecamente relacionada ao processo de produção da cidade, que impõe diversas demarcações de usos e funções espaciais, bem como estabelecem diretamente e/ou indiretamente legislações pré-estabelecidas para as permanências, que implicam em proibições e padronizações de comportamentos dos indivíduos, e na concorrência de usos pelo espaço por determinados grupos, geralmente, os conflitos cotidianos são latentes (ANTAS JÚNIOR, 2004).

1 O Parque agrega vários usos, como forma-urbana paisagística é visto como espaço técnico, resultado das estratégias do planejamento da cidade, logo possui arquitetura que promove práticas esportivas, comerciais e serviços (SILVA, 2001). 
Metodologicamente, a categoria jovem inseriu-se pela concepção do Instituto Brasileiro de Geografia e Estatística (IBGE), no qual estabelece que jovem, é o indivíduo com idade entre 15 e 24 anos. Portanto, nesse capítulo, a análise se pauta a partir da faixa etária que define, segundo o IBGE (1999), os jovens. Portanto, não discutiremos no campo teórico-conceitual a categoria juventude, que se caracteriza como uma condição e não um recorte etário, é definida pela identificação das mediações, das relações que conformam as experiências juvenis e de subjetivação aos sujeitos jovens (PAULA, 2013).

Os procedimentos metodológicos implicaram em idas e vindas ao Parque, isso posto, essas visitas presenciais nos promoveram várias indagações, quase de forma involuntária, instigando-nos a pensar, sobre a maneira de como os jovens criam e desenvolvem seus territórios. Perceptivelmente, incorremos em afirmar que os mesmos acabam por promover territorializações de usos no/do lugar, dadas tanto pelos diferentes grupos de jovens, quanto pelas relações territoriais entre jovens e não jovens. A provocação acerca da dinâmica de apropriação espacial se faz ligada, diretamente, ao questionamento sobre quem são estes jovens que frequentam o Parque Ipiranga.

Questionar o perfil ou os perfis dos jovens frequentadores da área de estudo apresenta um aspecto relevante, tendo em vista que se trata de uma área pública, que além dos investimentos para sua implementação, recebe constantes manutenções. Sendo assim, o estudo apresenta a seguinte questão: em que medida a localização do Parque Ipiranga, em uma área central da cidade, e a alta frequência de segmentos da população de elevado poder aquisitivo, determinam o público juvenil que ali frequenta?

A partir dessa indagação, outras emergem. Dentre elas, duas suscitam de maneira central na análise, quem são os jovens frequentadores do Parque Ambiental Ipiranga em Anápolis e qual é a configuração territorial juvenil do espaço? Para responder tais questões, a pesquisa se utilizou da aplicação de questionários estruturados, anotações no diário de campo e aplicações de entrevistas, assim os resultados serão apresentados de forma qualitativa e 
quantitativa1. Os dados obtidos correlacionam a construção teórica acerca das territorialidades de determinados grupos de jovens no lugar por via dos usos que designam seus processos de territorialização.

\section{APONTAMENTOS CONCEITUAIS SOBRE AS TERRITORIALIZAÇÕES DE JOVENS NO ESPAÇO PÚBLICO ANAPOLINO: PARQUE AMBIENTAL IPIRANGA}

O território torna-se um conceito-chave para a ciência geográfica (CORREA, 2000). Inicialmente, esteve na vertente tradicional assente na ideia ratzeliana, relacionado a partir da organização do solo físico, sobretudo, no século XIX, aquela apropriada pelos grupos ou organismos sociais, além de centrada nas relações de poder. Nessa abordagem, a relação do território estreita-se com a constituição do Estado-Nação, e o solo por ele controlado. Nesse sentido, as formas de controle e/ou apropriações do espaço estabelecem o poder atrelado à dinâmica territorial. Mas, durante quase todo século $X X$, essa próxima relação citada, imbricou-se posteriormente com as dimensões cultural (simbólica) e política do território.

Para tanto, o território passa a compreender a lógica de diferentes escalas, o desenvolvimento dos fluxos e fixos nele estabelecidos. A primeira concepção do território natural passa a ser correlacionada às redes (território-rede). Diante disso, outra questão envolve o território, em sua forma global, ele se fragmenta, delimitando-se por territorialidades. Essa segunda concepção designa diversas formas e usos dados ao território, mediados por relações intrínsecas de poder tanto do Estado/Capital bem como dos grupos sociais, se estabelecendo, ora numa relação de dominação/apropriação, ora na construção de identidades.

\footnotetext{
1 Vale ressaltar que para a aplicação dos questionários e realização das entrevistas, utilizamos de todas as medidas de precaução sanitárias, previstas na pandemia, para evitar o contagio e proliferação do novo coronavírus (Covid-19). Nesse sentido, respeitamos o distanciamento físico com os participantes da pesquisa, além do uso constante de máscara e álcool $70 \%$ (líquido e em gel). Além, é claro, da confidencialidade e respeito ético às respostas atribuídas pelos sujeitos que se dispuseram a contribuir com a pesquisa, da qual decorrem os resultados e discussões aqui empreendidas.
} 
Um ponto importante para se pensar a organização do território é sua integração, ao pensar o território do Estado-Nação pode-se optar por um forte diálogo com os demais territórios ou uma tentativa de se isolar. A localização de determinado território pode contribuir para predefinir se este vai se articular de forma intensa com os demais ou se segregar, ambas as opções apresentam contradições em si. Ainda na ideia do território do Estado-Nação, outro elemento importante é o tamanho e o contingente populacional, quanto menor for este território, mais vulnerabilidades tende a apresentar frente a diferentes possibilidades de ataques externos.

Para Raffestin (1993, p. 143, grifos do autor),

O território se forma a partir do espaço, é resultado de uma ação conduzida por um ator sintagmático (ator que realiza um programa) em qualquer nível. Ao se apropriar de um espaço, concreta ou abstratamente (por exemplo, pela representação), o ator "territorializa" o espaço.

Nesse sentido, o território é pautado por um sistema de objetivos e ações de conhecimentos e práticas, tal sistema é pensado a partir de quatro aspectos: econômicos, políticos, sociais e culturais. Os elementos espaciais e de organização do território são três: superfícies, pontos e linhas (RAFFESTIN, 1993). Com essa categorização Raffestin (1993) promoveu, no epicentro do pensamento geográfico, mudanças epistemológicas para o território. Eis a questão, para ele, o território é desinente do espaço geográfico, por quê? O ato de territorializar determinado espaço transforma indivíduos/grupos em atores dominantes e dominados.

Assim, entende-se o território como sendo:

[...] um espaço onde se projetou um trabalho, seja energia e informação, e que, por conseqüência, revela relações marcadas pelo poder. (...) o território se apóia no espaço, mas não é o espaço. É uma produção a partir do espaço. Ora, a produção, por causa de todas as relações que envolvem, se inscreve num campo de poder [...] (RAFFESTIN, 1993, p. 144).

Na análise de Raffestin (1993), a categoria essencial para a compreensão do território é o poder exercido por pessoas ou grupos. Assim, o poder é relacio- 
nal, pois está intrínseco em todas as relações sociais. As interpretações dessa concepção para o estudo em questão estão postas na compreensão de quem exerce os campos de poder e controle, criados pelas relações socioculturais produzidas pelos jovens no espaço do referido parque.

Para Haesbaert (1997) o território se constitui por três vertentes básicas: a jurídica-politica; culturalista e econômica. A primeira, conforme o autor, compreende que "[...] o território é visto como um espaço delimitado e controlado sobre o qual se exerce um determinado poder, especialmente o de caráter estatal" (p. 39). Já a segunda "prioriza sua dimensão simbólica e mais subjetiva, o território visto fundamentalmente como produto da apropriação feita através do imaginário ${ }^{1}$ e/ou identidade social sobre o espaço" (p. 39); e por último a econômica, "que destaca a des-territorialização em sua perspectiva material, concreta, como produto espacial do embate entre classes sociais e da relação capital-trabalho" (HAESBAERT, 1997, p. 39).

O autor reconhece que essas variações se efetivam em nível local ou micro que, ele identifica como uma multiterritorialidade, reunida em três elementos: a) os territórios-zona, prevalece a lógica política; b) os territórios-rede, prevalece a lógica econômica; e os c) aglomerados de exclusão, ocorre uma lógica social de exclusão socioeconômica das pessoas (HAESBAERT, 2004).

Nessa perspectiva o autor assente que

[...] esses três elementos não são mutuamente excludentes, mas integrados num mesmo conjunto de relações sócio-espaciais, ou seja, compõem efetivamente uma territorialidade ou uma espacialidade complexa, somente apreendida através da justaposição dessas três noções ou da construção de conceitos "híbridos" como o território-rede. (HAESBAERT, 2004 , p. 38, grifos do autor).

Na trilha da construção teórica sobre as territorialidades, a contribuição de Haesbaert (2004) sugere associar ao controle físico ou à dominação "objetiva"

1 Imaginário visto aqui num sentido amplo como "(...) o conjunto de representações, crenças, desejos, sentimentos, em termos dos quais um indivíduo ou grupo de indivíduos vê a realidade e a si mesmo" e não no sentido sartreano de rompimento com o mundo, "desligamento da plenitude do dado" (JAPIASSU, MARCONDES, 1990, p. 129-130). 
do espaço, a apropriação simbólica, mais subjetiva; isto implica discutir o território enquanto espaço simultaneamente dominado e apropriado, ou seja, sobre o qual se constrói não apenas um controle físico, mas também laços de identidade social.

A dominação do território por grupos ou segmentos socioculturais e econômicos traz como consequência o crescimento das desigualdades sociais, também, resulta no fortalecimento das diferenças entre os grupos. A ideia sobre a territorialidade retoma o espaço das inter-relações e das interações. Ao efetivar essas interações, as possibilidades de territorializações passam denotar a multiplicidade dos usos.

Para discutirmos a territorialização de jovens, precisamos seguir esse raciocínio, no parque o espaço se apresenta pela multiplicidade de processos, ali é visível um intenso grau de interação dos grupos juvenis com outros grupos não jovens, bem como a ocorrência de isolamento para com outros grupos. Tais grupos criam suas territorialidades de forma escalonada e por agrupamentos em um espaço especifico, os mesmos buscam circular pelo parque a fim de ampliar suas redes de sociabilidade.

De acordo com Souza (2000, p. 78), "O território [...] é fundamentalmente um espaço definido e delimitado por e a partir de relações de poder". A percepção do território se liga diretamente a aspectos de domínio e poder, a capacidade de atuar e dominar esse espaço. Além da possibilidade de diferentes escalas para se pensar o território, este também pode apresentar uma característica fluida, modificando seus usos e grupos que exercem o poder em diferentes escalas temporais de curto, médio e longo prazo. Um grupo que exercer o poder em um território durante a parte da manhã não necessariamente vai dominar esse espaço durante a noite, ou mesmo a alternância de poder pode ocorrer durante períodos do ano, e claro que também pode acontecer à perda deste poder para outro grupo. Desta forma, o território também pode apresentar uma característica de mobilidade, que tende a ocorrer por meio de conflitos, sejam físicos ou simbólicos. 
Conforme Gottmann (2012, p. 523), "o território consiste, é claro, de componentes materiais ordenados no espaço geográfico de acordo com certas leis da natureza. Entretanto, seria ilusório considerar o território como uma dádiva divina e como um fenômeno puramente físico". A cerca dos componentes presentes no território, mais importante do que riquezas naturais, se faz a capacidade de organizar este espaço. O território é um conceito geográfico e político, pois o espaço geográfico se organiza através de processos políticos, sendo necessário a uma teoria política pensar as características e diferenças do espaço geográfico (GOTTMANN, 2012).

Para tanto, durante a pesquisa foi elaborado um instrumento do tipo questionário, estruturado com 8 perguntas objetivas, o qual foi aplicado a uma parcela dos jovens presentes no parque. Ao todo, foram aplicados 70 questionários, tendo sido apenas dois descartados, pois os indivíduos não se encaixavam na faixa etária de 15 a 24 anos. Do número absoluto de questionários, 50\% foram aplicados em uma terça-feira no horário entre 19 e 22 horas, os outros $50 \%$ foram aplicados em um sábado no mesmo horário.

Optou-se por realizar a análise dos dados obtidos a partir de uma abordagem "mista", utilizando tanto a perspectiva quantitativa, como a qualitativa. A partir dos questionários foram elaborados gráficos e também se realizou inferências. As perguntas presentes no questionário foram pensadas com intuito de mapear o perfil dos jovens que frequentam o parque e se essa dinâmica territorial se modifica de um dia tido como meio de semana para o final da semana. Posto algumas considerações sobre território, na próxima seção iremos discutir como se dá essa apropriação e dinâmica territorial por parte dos jovens no Parque Ambiental Ipiranga em Anápolis, Goiás.

\section{O PARQUE AMBIENTAL TERRITORIALIDADES JUVENIS}

IPIRANGA

$\mathbf{E}$ AS

Um aspecto do território é que ele pode ser fluido, os grupos que exercem e se estabelecem neste espaço podem ir se modificando, tanto conforme o 
passar do tempo, quanto com os períodos do ano ou até mesmo da semana. No caso do Parque Ambiental Ipiranga, é perceptível que os grupos de jovens que se apropriam daquele determinado espaço se modificam conforme os dias da semana. Tal fenômeno é observável a partir dos resultados descritos nos gráficos das ilustrações 02 e 03.

Ilustração 02: Gráfico - Distância entre a residência dos jovens e o Parque Ambiental Ipiranga (dados coletados na terça-feira)

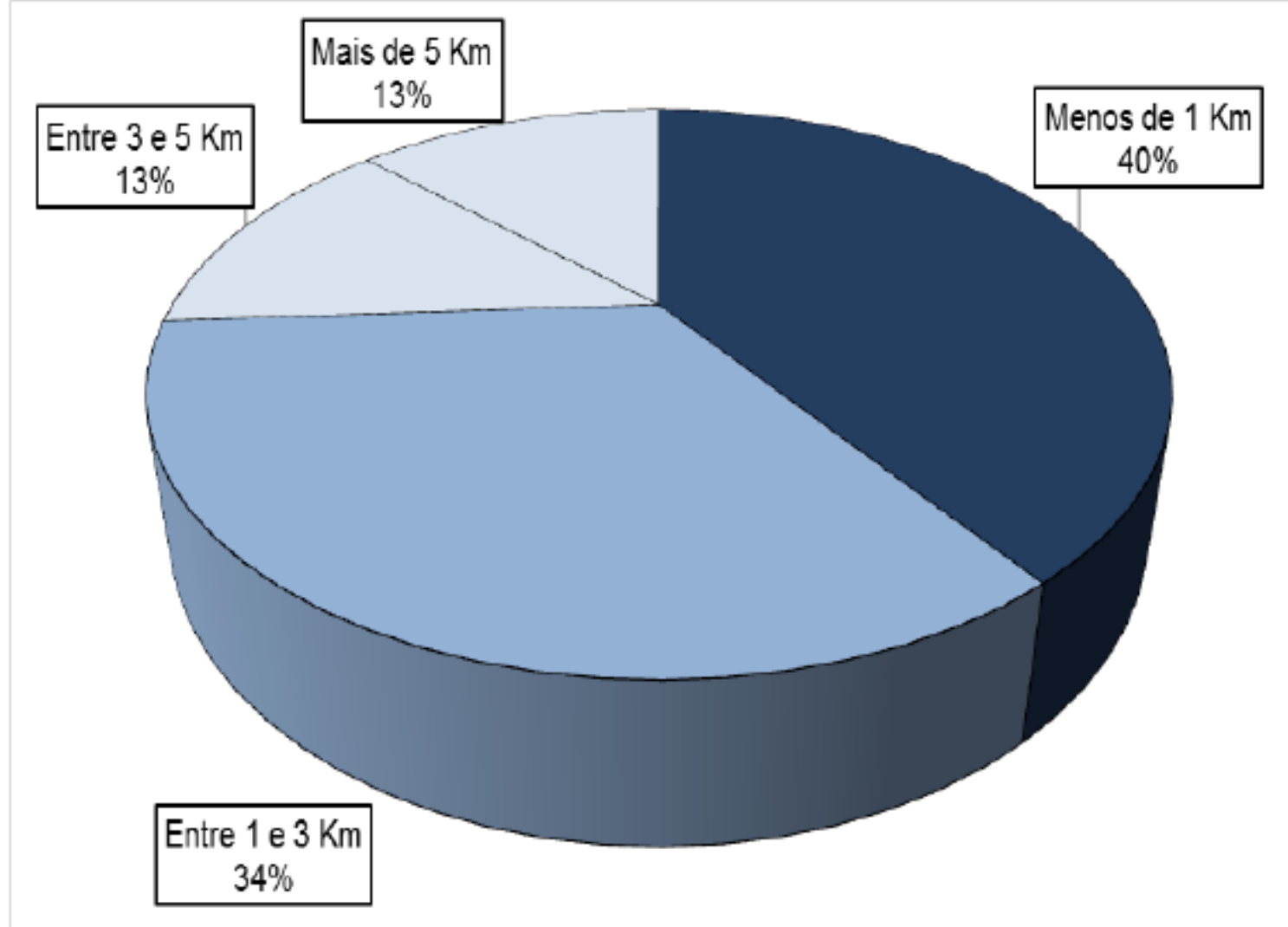

Fonte: Informações obtidas no trabalho de campo por meio da aplicação dos questionários (2021).

Organização dos dados: os autores (2021).

$\mathrm{Na}$ terça-feira, percebe-se que a maioria dos jovens que frequentam o parque residem a uma distância inferior a $1 \mathrm{~km}$ ou a uma distância entre 1 e 3 $\mathrm{km}$. Do total, temos $40 \%$ dos jovens residentes a menos de $1 \mathrm{~km}, 34 \%$ entre 1 e 3 $\mathrm{km}$, ou seja $74 \%$ possuem residência a uma distância de menos de $3 \mathrm{~km}$. Apenas $13 \%$ reside entre 3 e $5 \mathrm{~km}$, porcentagem igual a daqueles que residem a mais de $5 \mathrm{~km}$ de distância do parque. 
Ilustração 03: Gráfico - Distância entre a residência dos jovens e o Parque Ambiental Ipiranga (dados coletados no sábado)

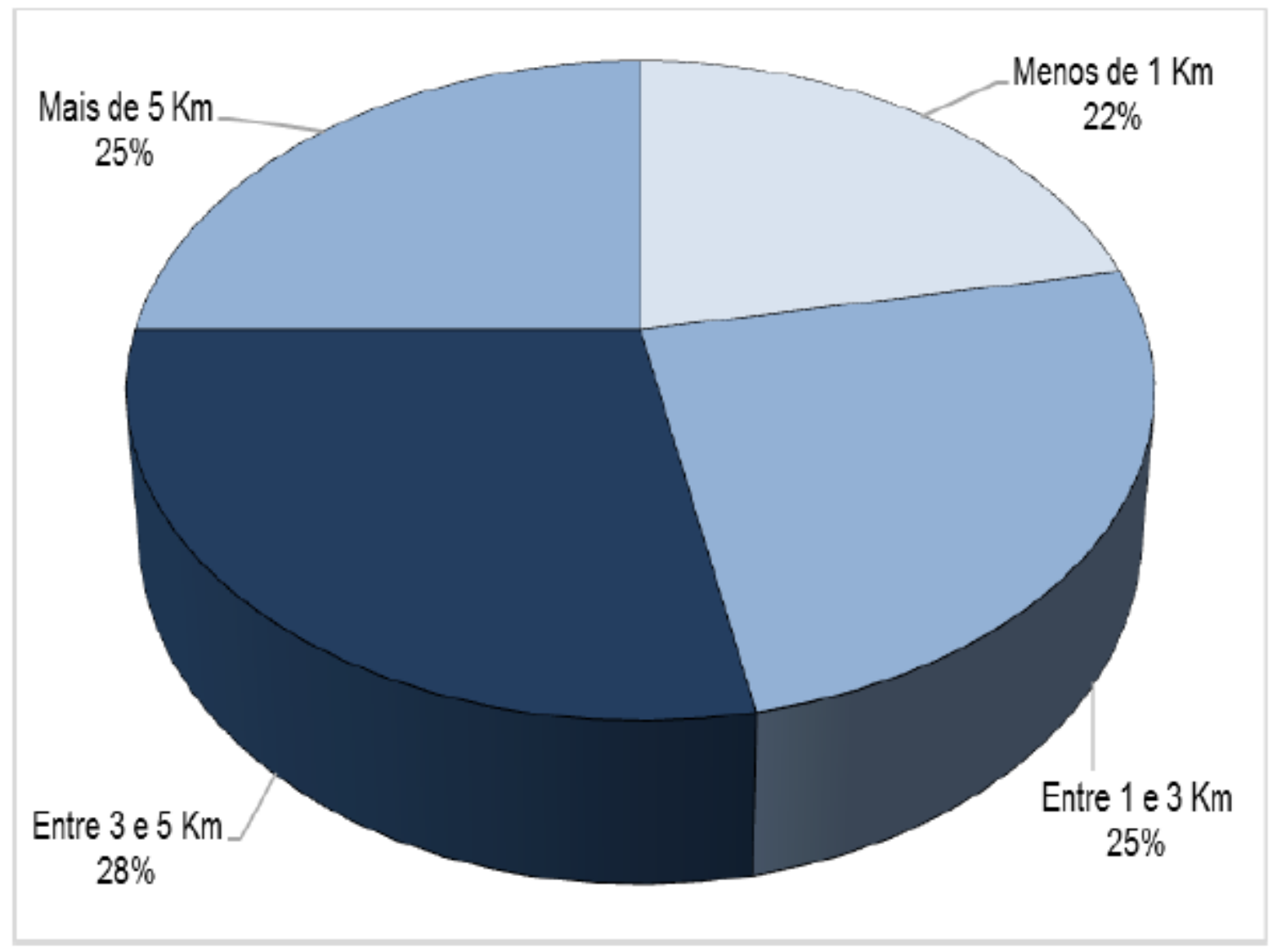

Fonte: Informações obtidas no trabalho de campo por meio da aplicação dos questionários (2021).

Organização dos dados: os autores (2021).

No sábado, o maior número de jovens que frequentam o parque residem entre 3 e 5 km, com $28 \%$ dos questionário válidos; seguido por $25 \%$ que residem entre 1 e $3 \mathrm{~km}$, número igual ao daqueles que moram a mais de $5 \mathrm{~km}$ do parque. O menor número refere-se aos residentes a menos de $1 \mathrm{~km}$ de distância, correspondendo a $22 \%$ dos jovens que responderam os questionários.

A comparação entre as ilustrações 02 e 03 revelam alguns pontos a serem destacados, enquanto na terça-feira quase $3 / 4$ dos jovens residem a menos de $3 \mathrm{~km}$ do parque, no sábado os números apresentam um equilíbrio muito maior. Os jovens que residem a menos de $3 \mathrm{~km}$ (sábado) não chegam a $50 \%$ do total, apresentando assim uma clara diferença no público de jovens que se apropriam daquele território conforme o dia da semana. 
Ilustração 04: Gráfico - Frequência de ida dos jovens ao Parque Ambiental Ipiranga (dados coletados na terça-feira)

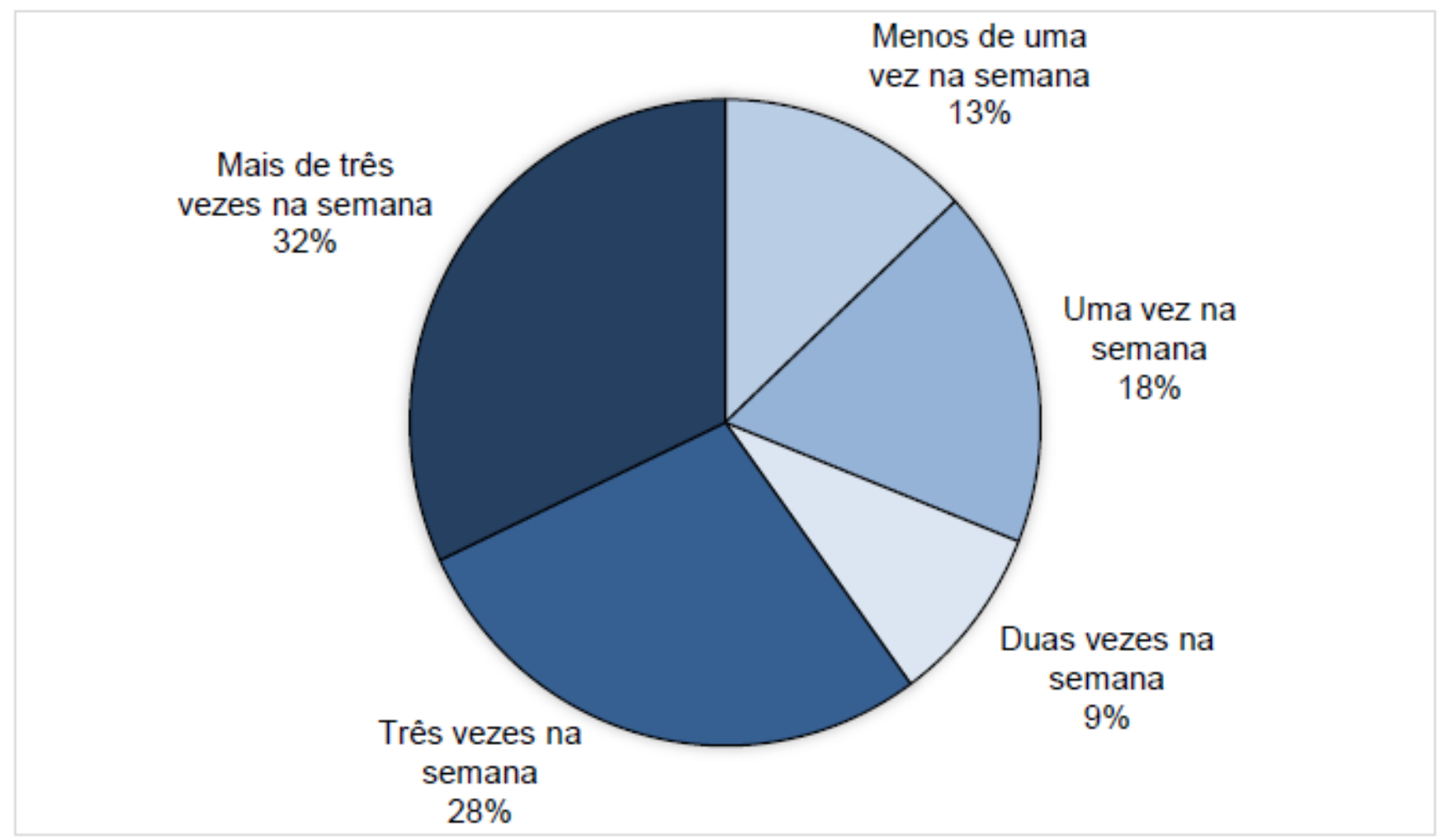

Fonte: Informações obtidas no trabalho de campo por meio da aplicação dos questionários (2021).

Organização dos dados: os autores (2021).

O gráfico da ilustração 04 apresenta que do total, $60 \%$ dos jovens que vão ao parque na terça-feira costumam ir pelo menos três vezes na semana, sendo que $32 \%$ dos que responderam vão ao parque mais de três vezes na semana e $28 \%$ disseram ir três vezes por semana. $9 \%$ afirmaram que vão duas vezes por semana, outros $18 \%$ vão uma única vez por semana, enquanto $13 \%$ vão com menor frequência, menos de uma vez por semana. A relação entre a proximidade da residência e a frequência de ida ao parque fica clara ao constatar que os $13 \%$ que vão menos de uma vez à semana ao parque estão entre aqueles que residem a mais de $3 \mathrm{~km}$ de distância. 
Ilustração 05: Gráfico - Frequência de ida dos jovens ao Parque Ambiental Ipiranga (dados coletados no sábado)

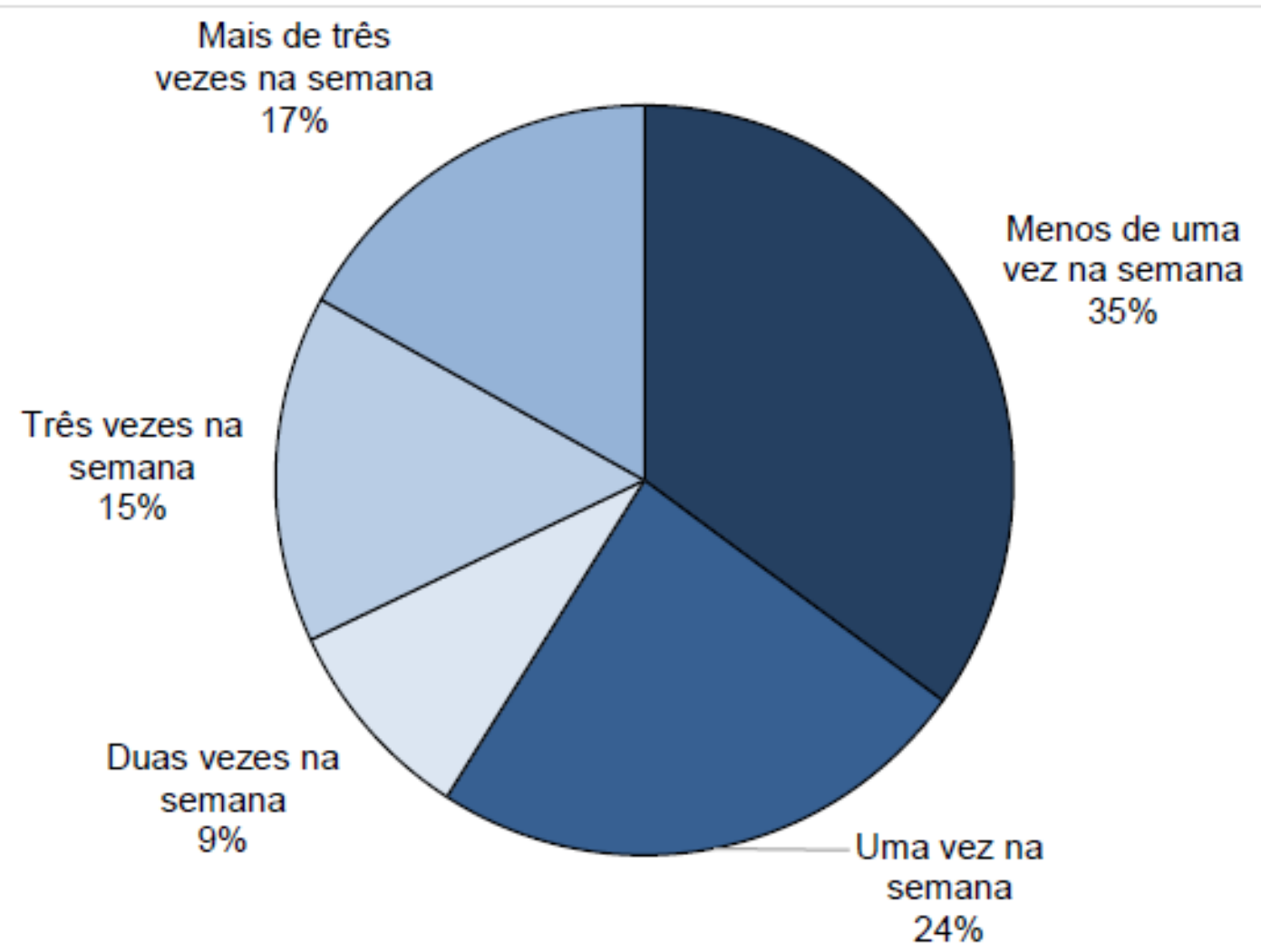

Fonte: Informações obtidas no trabalho de campo por meio da aplicação dos questionários (2021).

Organização dos dados: os autores (2021).

A frequência de ida dos jovens ao parque de acordo com os dados obtidos no sábado apresenta os seguintes resultados: quase $60 \%$ vão no máximo uma vez por semana. A maior parcela dos jovens que responderam ao questionário vão ao parque, em média, menos de uma vez por semana, esse grupo corresponde a $35 \%$, a segunda maior parcela é a daqueles que vão uma vez à semana ao parque, representando $24 \%$ do número total. Outros $9 \%$ vão duas vezes por semana, e $15 \%$ três vezes na semana, outros $17 \%$ costumam ir mais de três vezes no decorrer da semana.

A clara diferença dos números presentes nos gráficos das ilustrações 04 e 05 indicam que o perfil dos jovens que frequentam o parque na terça-feira são sujeitos que possuem uma maior constância de visitação. Enquanto na terça-feira, cerca de $60 \%$ vai ao parque pelo menos três vezes na semana, já no sábado, 
esse número é de apenas $32 \%$. No sábado, $59 \%$ dos jovens vão ao parque no máximo uma vez na semana, já na terça essa frequência corresponde a apenas $31 \%$.

Ilustração 06: Gráfico - Renda familiar dos jovens frequentadores do Parque Ambiental Ipiranga em salários mínimos (dados coletados na terça-feira)

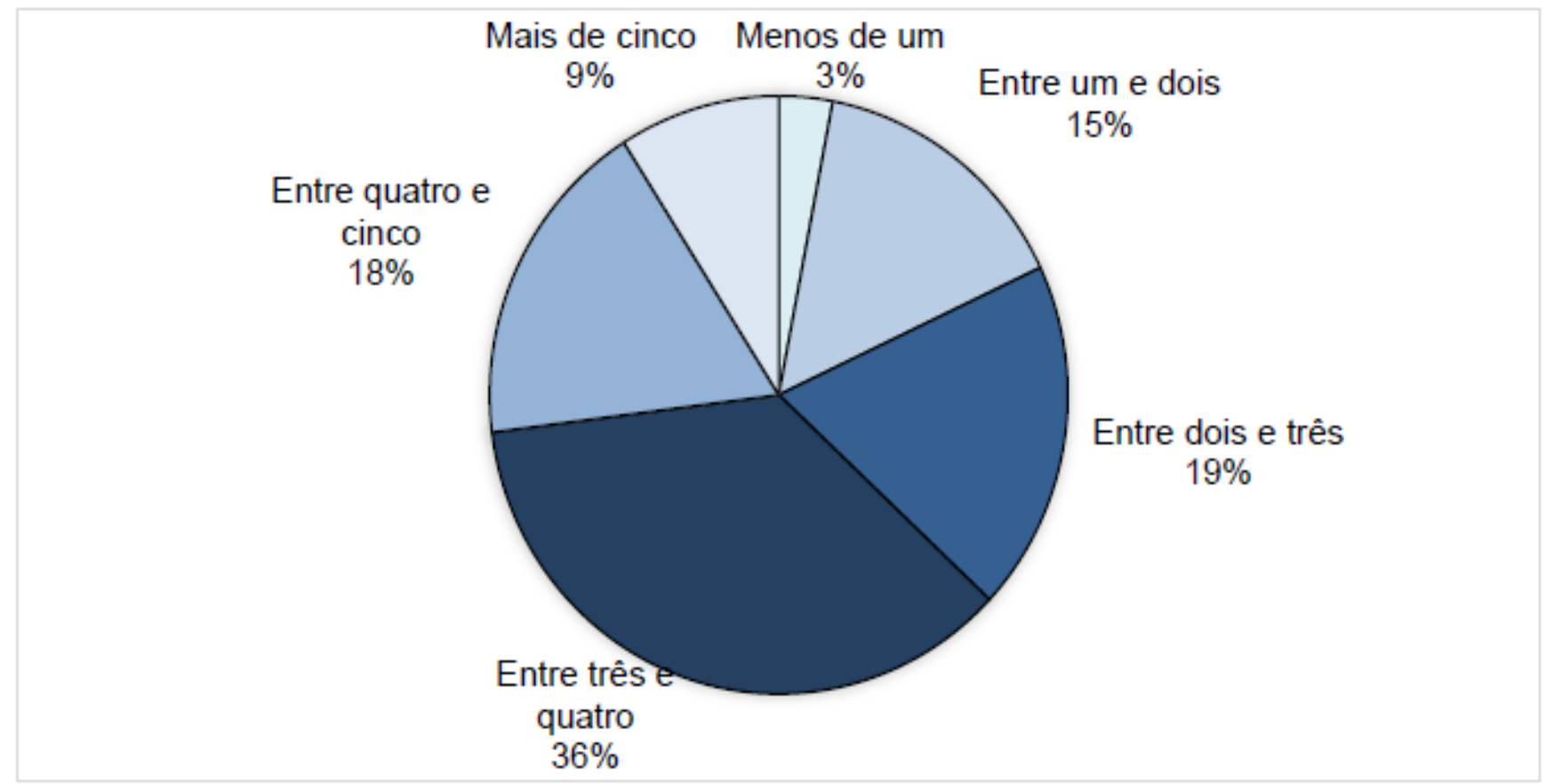

Fonte: Informações obtidas no trabalho de campo por meio da aplicação dos questionários (2021).

Organização dos dados: os autores (2021).

Dos jovens que frequentam o parque ipiranga na terça-feira $82 \%$ possuem renda familiar acima de dois salários mínimos, conforme demonstra a ilustração 06. Já $19 \%$ apresentam uma renda familiar entre dois e três salários mínimos; $36 \%$ entre três e quatro salários mínimos; $18 \%$ entre quatro e cinco salários mínimos e outros $9 \%$ acima de cinco salários mínimos. $15 \%$ são jovens que a família ganha entre um e dois salários mínimos e apenas 3\% recebem menos de um salário mínimo mensal. 
Ilustração 07: Gráfico - Renda familiar dos jovens frequentadores do Parque Ambiental Ipiranga em salários mínimos (dados coletados no sábado)

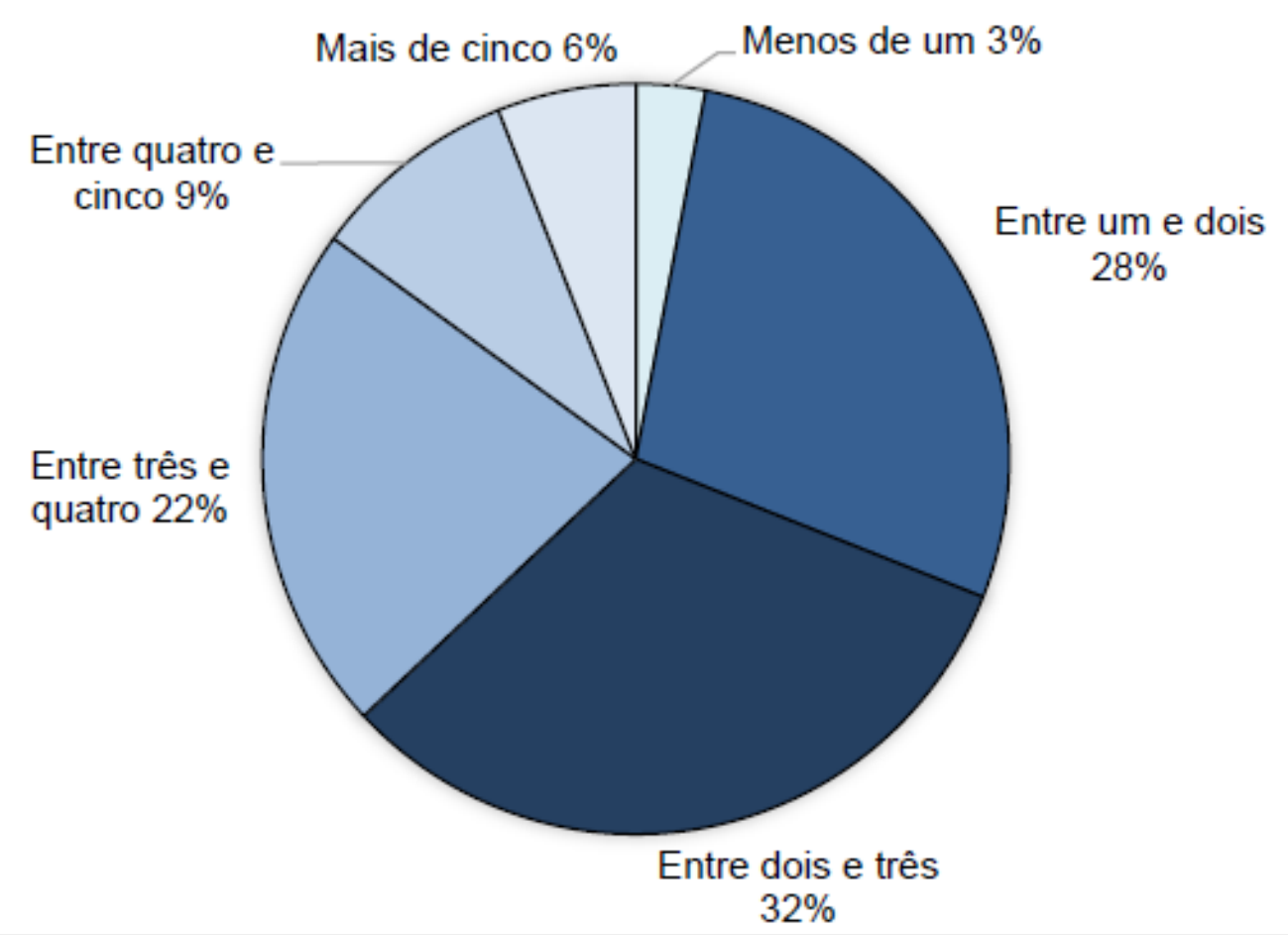

Fonte: Informações obtidas no trabalho de campo por meio da aplicação dos questionários (2021).

Organização dos dados: os autores (2021).

Entre os jovens que frequentam o parque no sábado, $69 \%$ apresentam uma renda familiar superior a dois salários mínimos. $32 \%$ afirmam que a renda familiar fica entre dois e três, e os que disseram possuir renda entre três e quatro salários mínimos correspondem a $22 \%$. Enquanto aqueles que a renda familiar fica entre quatro e cinco salários mínimos correspondem a $9 \%$, e os que possuem renda familiar acima de cinco salários mínimos representam $6 \%$. Do total, $28 \%$ disseram possuir renda familiar entre um e dois salários mínimos, e outros $3 \%$ disseram que a família apresenta uma renda que não chega a um salário mínimo.

Ao compararmos os números dos gráficos, ilustrações 06 e 07, nota-se que em média os jovens que frequentam o Parque Ambiental Ipiranga na terçafeira possuem um poder aquisitivo superior àqueles que frequentam no sábado. Enquanto $31 \%$ dos jovens que responderam ao questionário no sábado possuem renda familiar inferior a dois salários mínimos, na terça-feira essa faixa de renda representa apenas $18 \%$ dos questionários respondidos. Se ampliarmos para 
aqueles que apresentam renda familiar de até três salários mínimos, terça-feira conta com $37 \%$, e o sábado comtempla $63 \%$ dos entrevistados.

Ilustração 08: Gráfico - Idade dos jovens que frequentam o Parque Ambiental Ipiranga (dados coletados na terça-feira)

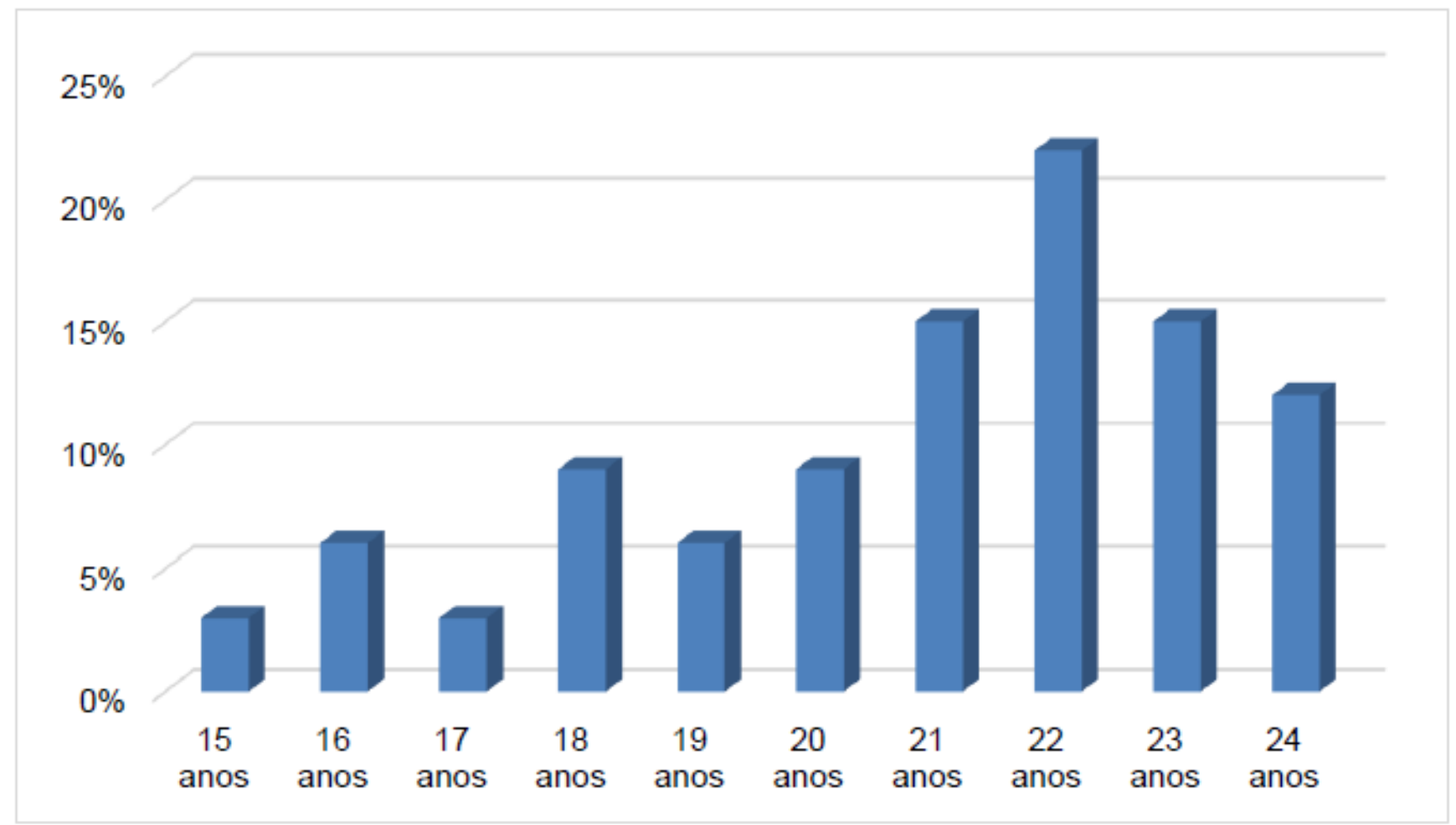

Fonte: Informações obtidas no trabalho de campo por meio da aplicação dos questionários (2021).

Organização dos dados: os autores (2021).

O número de jovens com idade entre 15 e 19 anos que responderam ao questionário na terça-feira representa apenas $27 \%$ do total de questionários aplicados. Dessa forma a maior parcela dos jovens participantes na terça-feira possuem idade entre 20 e 24 anos. Do total, 3\% possuem quinze anos, $6 \%$ têm 16 anos, e $3 \%$ possuem 17 anos; além destes, outros $9 \%$ já possuem 18 anos e $6 \%$ tem 19 anos. Os jovens com vinte anos representam $9 \%$, com vinte e um anos $15 \%$, já $22 \%$ dos jovens possuem vinte e dois anos, enquanto $15 \%$ possuem vinte e três anos e $12 \%$ vinte e quatro. 
Ilustração 09: Gráfico - Idade dos jovens que frequentam o Parque Ambiental Ipiranga (dados coletados no sábado)

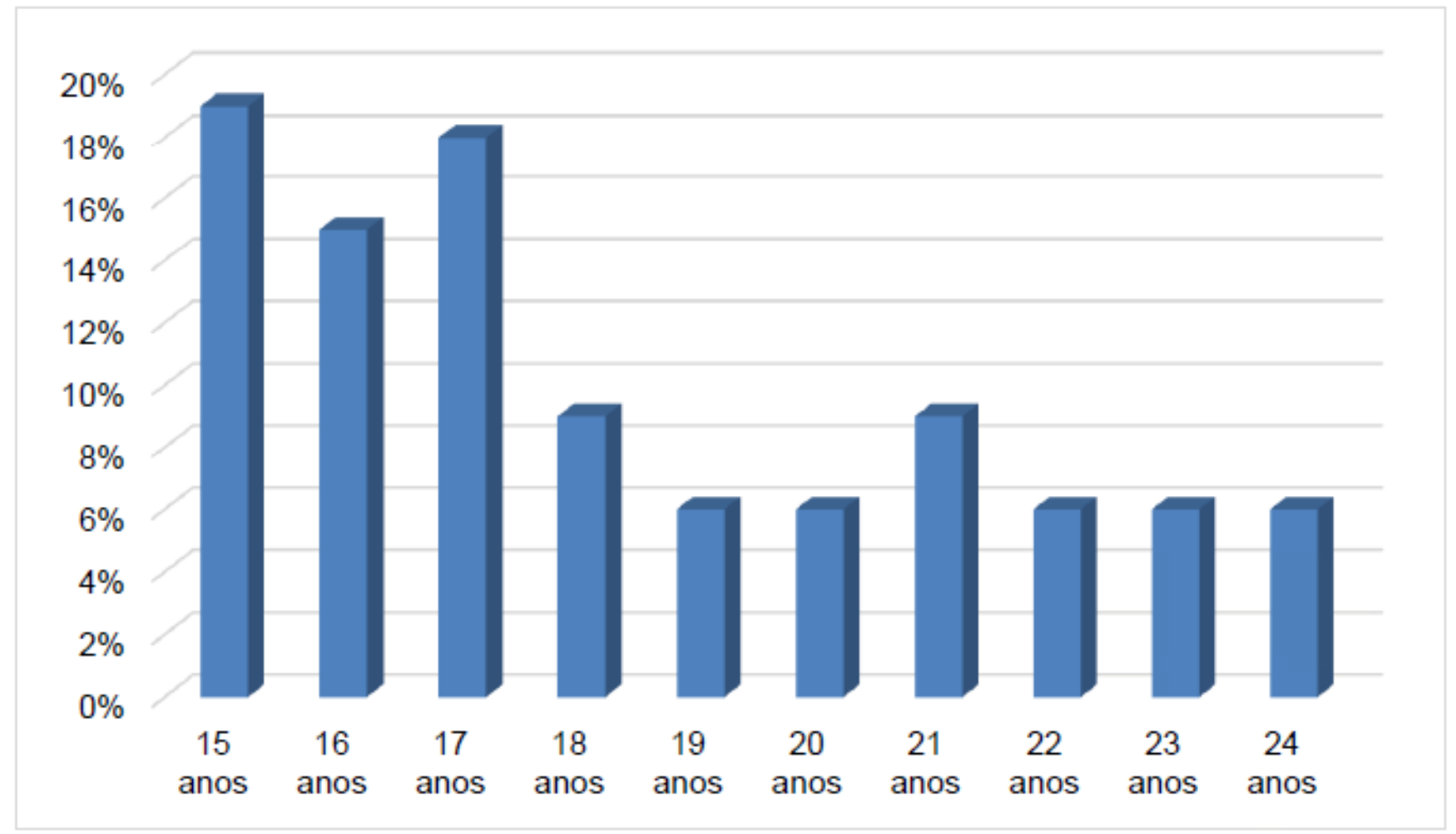

Fonte: Informações obtidas no trabalho de campo por meio da aplicação dos questionários (2021).

Organização dos dados: os autores (2021).

No sábado, $67 \%$ por cento dos jovens que responderam ao questionário possuem idade entre 15 e 19 anos, representando dessa forma uma parcela maior que aqueles com idade entre 20 e 24 anos. Desses, 19\% tem quinze anos, 15\% possuem dezesseis, $18 \%$ com dezessete anos, $9 \%$ possuem dezoito anos e $6 \%$ têm dezenove anos. Os jovens com vinte anos representam $6 \%$, com vinte e um anos $9 \%$, outros $6 \%$ dos jovens possuem vinte e dois anos, mesma porcentagem daqueles que têm vinte e três e também vinte e quatro anos.

Os números dos gráficos das ilustrações 08 e 09 expressam que na terça feira o grupo de jovens que frequentam o parque são mais velhos, estando mais próximos dos vinte e quatro anos, enquanto no sábado apresenta uma tendência de sujeitos jovens mais novos. Fica evidente essa constatação quando a porcentagem de jovens com menos de 20 anos mais do que dobra de terça para sábado, saindo de $27 \%$ para $67 \%$, respectivamente. 
Ilustração 10: Fotografia - Registro de um momento de socialização dos jovens no Parque Ambiental Ipiranga (sábado)

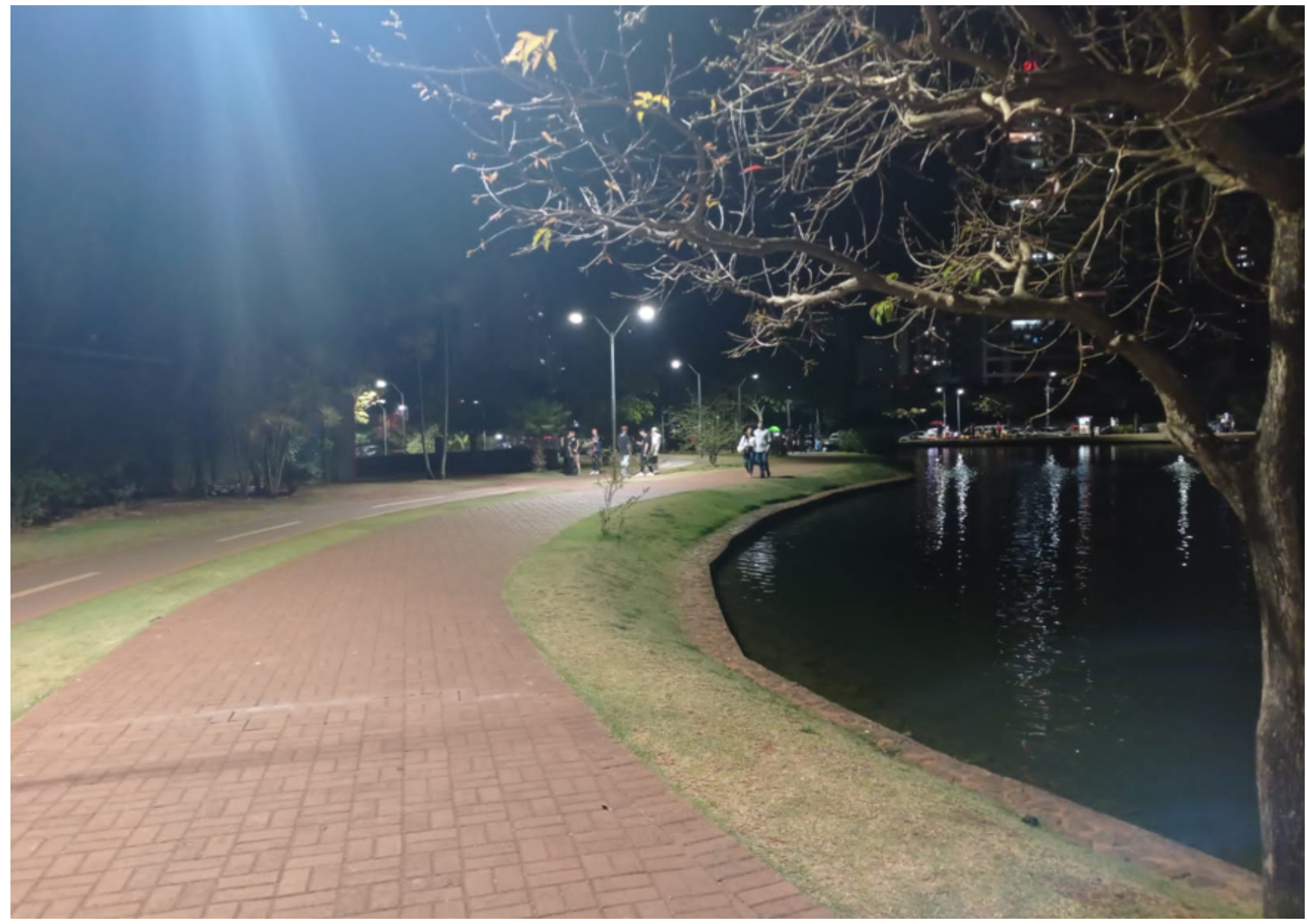

Fonte: os autores (2021).

Na ilustração 10, temos uma fotografia tirada em um sábado, é possível observar um ambiente de socialização dos jovens no Parque Ipiranga. A imagem comtempla, ao mesmo tempo, um casal de jovens andando abraçados, e um grupo de jovens, aparentemente de amigos, que estão utilizando as dependências do parque para desenvolverem suas redes e circuitos de sociabilidade juvenil. Cenas como essa da fotografia costumam ocorrer com maior frequência aos finais de semana, enquanto nos outros dias da semana o parque costuma ser utilizado de forma mais acentuada para a prática de esportes, tal como corrida, caminhada, patinação, dentre outros. 


\section{CONSIDERAÇÕES FINAIS}

O Parque Ambiental Ipiranga em Anápolis (GO) se configura como um importante ponto de encontro, um espaço de lazer e que apresenta expressivas territorialidades juvenis, as quais são marcadas pela fluidez, ao passo em que a apropriação deste território se modifica conforme o dia da semana. A partir dos dados obtidos com o questionário e a observação participante conclui-se que o público jovem que frequenta o parque no decorrer da semana se difere daquele presente aos finais de semana. A proximidade da residência com o parque e o poder aquisitivo, além de outros fatores, contribuem para este cenário, pois os jovens, ao se verem limitados de irem ao parque mais vezes, sobretudo ao longo da semana, acabam priorizando os finais de semana.

Uma diferença observada é a mudança de como o parque é utilizado, pois durante a semana o público que frequenta acaba se restringindo à prática de esportes, em especial para correrem e efetuarem caminhadas na pista de atletismo, mas também para andarem de bicicleta, skate, patinete e patins. Já aos finais de semana o parque sofre uma ressignificação em seu território por parte dos jovens, o espaço torna-se, prioritariamente, um ponto de encontro entre casais e amigos.

Assim, outro ponto de destaque do Parque Ipiranga é o do aspecto de socialização aos finais de semana, sendo fácil encontrar grupos de jovens reunidos, enquanto de segunda até sexta-feira é mais comum que estes estejam lá sozinhos ou apenas em duplas. Portanto, percebe-se que os jovens que frequentam o parque no decorrer da semana, acabam buscando outros tipos de lazeres aos finais de semana, como se houvesse uma hierarquia simbólica entre o lazer presente no parque e o que se pode obter nos bares e restaurantes situados nas proximidades; o que aos finais de semana, acabam se tornando atrativos ao público jovem anapolino. 


\section{REFERENCIAS}

ANTAS JÚNIOR, Ricardo Mendes. Elementos para uma discussão epistemológica sobre a regulação no território. GEOUSP - Espaço e Tempo, São Paulo, v. 8, n. 2, p. 81-86, jul./dez., 2004. https://doi.org/10.11606/issn.2179-0892. geousp.2004.73956. Disponível em: https://www.revistas.usp.br/geousp/article/ view/73956. Acesso em: 10 out. 2021.

CORREAA, Roberto Lobato. Espaço: um conceito-chave da Geografia. In: CASTRO, Iná Elias de; GOMES, Paulo Cesar da Costa; CORREAA, Roberto Lobato. Geografia: conceitos e temas. 2. ed. Rio de Janeiro: Bertrand Brasil, 2000, p. 15-48. Disponível em: https://toaz.info/doc-viewer. Acesso em: 8 ago. 2021.

GOTTMANN, Jean. A evolução do conceito de território. Boletim Campineiro de Geografia, Campinas, v. 2, n. 3, p. 523-545, set./dez., 2012. Disponível em: http://agbcampinas.com.br/bcg/index.php/boletim-campineiro/article/view/86. Acesso em: 14 jul. 2021.

HAESBAERT, Rogério. Da desterritorialização à multiterritorialidade. Boletim gaúcho de Geografia, Porto Alegre, v. 29, n. 1, p. 11-24, jan./jun., 2003. Disponível em: https://www.seer.ufrgs.br/bgg/article/view/38739. Acesso em: 12 set. 2019.

HAESBAERT, Rogério. Des-territorialização e identidade: a rede "gaúcha" no Nordeste. Niterói: EDUFF, 1997. Disponível em: https://app. uff. br/riuff/bitstream/handle/1/15086/Des-territorializacao-e-identidade. pdf;jsessionid=CB9CFF2A9A2A681E8887275BDC3276D0 ? sequence $=1$. Acesso em: 9 set. 2021.

HAESBAERT, Rogério. O mito da desterritorialização: do fim dos territórios à multiterritorialidade. Rio de Janeiro: Bertrand Brasil, 2004.

IBGE - Instituto Brasileiro de Geografia e Estatística. População jovem no Brasil. Rio de Janeiro: Departamento de População e Indicadores Sociais, 1999. Disponível em: https://biblioteca.ibge.gov.br/visualizacao/livros/liv6686.pdf. Acesso em: 5 fev. 2021. 
PAULA, Flávia Maria de Assis. Jovens migrantes na metrópole de Goiânia: práticas espaciais, (re)territorializações e redes de sociabilidade. 2013. Tese (Doutorado em Geografia), Programa de Pós-Graduação em Geografia, Instituto de Estudos Socioambientais, Universidade Federal de Goiás, Goiânia, 2013. Disponível em: https://repositorio.bc.ufg.br/tede/handle/tde/2917. Acesso em: 12 set. 2019.

RAFFESTIN, Claude. Por uma Geografia do Poder. São Paulo: Ática, 1993.

SILVA, Mary Anne Vieira. A Praça do Ferreira: seu uso e apropriação. 2001. Dissertação (Mestrado em Geografia), Programa de Pós-Graduação em Geografia Humana, Departamento de Geografia, Faculdade de Filosofia, Letra e Ciências Humanas, Universidade de São Paulo, São Paulo, 2001.

SOUZA, Marcelo José Lopes de. Mudar a cidade: uma introdução crítica ao planejamento e à gestão urbana. Rio de Janeiro: Bertrand Brasil, 2002.

SOUZA, Marcelo José Lopes de. O território: sobre espaço e poder, autonomia e desenvolvimento. In: CASTRO, Iná Elias de; GOMES, Paulo Cesar da Costa; CORREA, Roberto Lobato. Geografia: conceitos e temas. 2. ed. Rio de Janeiro: Bertrand Brasil, 2000, p. 77-116. Disponível em: https://toaz.info/doc-viewer. Acesso em: 8 ago. 2021.

VIVA ANÁPOLIS. Parques valorizam regiões em até 300\%. Viva Anápolis, Anápolis, s./p., 6 fev. 2016. Disponível em: http://vivaanapolis.com.br/parquesvalorizam-regioes-em-ate-300/. Acesso em: 20 out. 2021. 


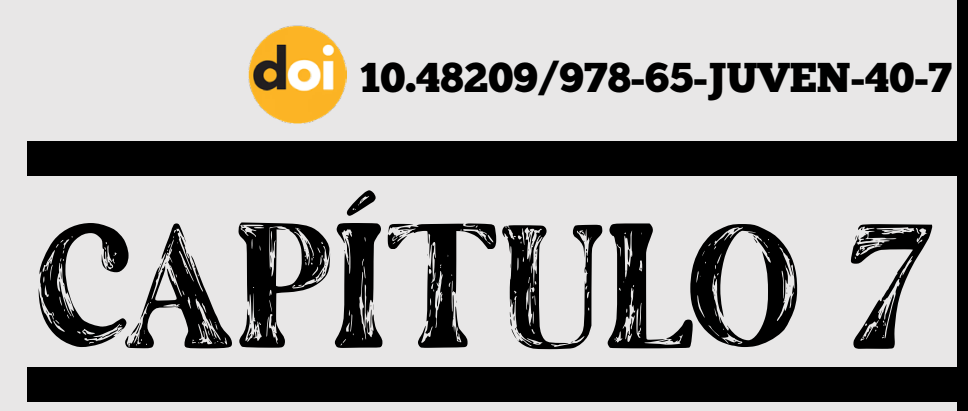

\section{AS JUVENTUDES E O FUTURO:} (RE)PENSANDO PROCESSOS EDUCACIONAIS COM A ESCOLA DE HOJE'

Luís Paulo Cruz Borges

$1 \quad$ Trabalho apresentado e publicado nos Anais do I Simpósio Internacional Juventudes e Educação: Cenários educacionais em tempos de reformas. Juazeiro(BA) Complexo - Virtual, 2020, contudo o mesmo foi revisto e ampliado para a presente publicação. 


\section{INTRODUÇÃO}

O que é ser jovem? A pergunta, aparentemente, simples evoca muitos sentidos e significados correlatos à juventude, ou mesmo, juventudes no plural. Na década de 1980, o sociólogo Pierre Bourdieu (1983) nos instiga a pensar que "juventude é apenas uma palavra". O autor vai revelando uma complexidade que nos faz problematizar o conceito de juventude a partir do olhar sociológico.

De acordo com dados do Instituto de Pesquisa Econômica Aplicada (Ipea) de 2018, com o estudo "Millennials na América e no Caribe: trabalhar ou estudar?", há cerca de 33 milhões de jovens brasileiros com idade entre 15 e 24 anos, o que corresponde mais de $17 \%$ da população. O Instituto informa que $23 \%$ dos jovens no Brasil não trabalham e nem estudam, sendo considerados jovens "nem-nem". Uma adjetivação que vem ganhando destaque, sobretudo, na grande mídia. Contraditoriamente, a mesma pesquisa revela que os jovens vêm buscando trabalho. Os dados indicam que " $31 \%$ dos deles estão procurando trabalho, principalmente os homens e, mais da metade, $64 \%$, dedicam-se a trabaIhos de cuidado doméstico e familiar, principalmente as mulheres". Percebemos, assim, leituras possíveis para as desigualdades de gênero.

Em diálogo com a pesquisa do Ipea (2018), encontramos um estudo em 2020, Juventudes e a Pandemia do Coronavírus', realizado pelo Conselho Nacional da Juventude (Conjuve) que teve como seu principal objetivo analisar as consequências da crise sanitária sobre a vida dos jovens brasileiros em suas perspectivas para o futuro. A pesquisa realizada pelo Conjuve nos ajuda a pensar sobre as condições materiais vividas pelas/pelos jovens indicando questões ligadas a um equilíbrio emocional; ao tempo de estudo; as condições físicas de trabalho e aos impactos sobre o futuro causados pelo isolamento social.

Quais as muitas dimensões do que é ser jovem no Brasil? Especificamente, podemos pensar no estado do Rio de Janeiro, ser estudante de escola pública e morador de favela. As juventudes e seus dilemas, atualmente, vêm encarnando 1 Disponível em: https://oji.fundacion-sm.org/juventudes-e-a-pandemia-do-coronavirus. Acessado em 10 de outubro de 2021. 
discursos e corpos que estão presentes nas tevês, jornais, redes sociais, nos estudos, enfim, "na boca do povo".

A empiria da presente pesquisa, como parte de um doutoramento, foi desenvolvida durante o período de sete meses junto a alunos e alunas do Ensino Médio (turmas de $2^{\circ}$ e $3^{\circ}$ anos) de uma escola pública no estado do Rio de Janeiro, Nova Iguaçu, que carregam consigo o qualificador de jovens, ou seja, são os sujeitos que também fazem parte da juventude do país de forma abrangente. São afrodescendentes em sua grande maioria; oriundos das classes populares, sendo moradores da Baixada Fluminense, região com sérias questões sociais e econômicas. O jovem-estudante da investigação tem entre 14 e 19 anos cursando o Ensino Médio. Aqui, apenas, apresentaremos um recorte com foco nos processos educacionais em sua relação entre juventudes e futuro, assim, objetivamos detalhar como tais processos são vividos/sentidos pelos/pelas jovens na pesquisa etnográfica.

Assumimos a perspectiva do olhar, que durante toda a pesquisa se fez presente com uso do termo observação participante. A observação, materializada em notas etnográficas, produziu um relatório de campo, gerando as reflexões e as categorias do estudo. Foi assim que o olhar dos alunos e alunas da escola foi se entrecruzando com o olhar do pesquisador. Foram olhares que, se chocando, foram produzindo percepções de mundo. Pode-se defender a ideia de que o pesquisador ainda é o principal responsável pela feitura e pela organização das informações investigadas no âmbito da pesquisa e por isso mesmo guia o olhar na percepção do que deseja investigar (LÜDKE; ANDRÉ, 1986). A partir do olhar dos estudantes que participaram da pesquisa há uma complexidade posta às formas de compreensão através do eu e do Outro que foram mapeadas, também, por meio de entrevistas etnográficas, análise de documentos da escola e produção escrita dos estudantes (redação).

A investigação traz a possibilidade da emergência de descrição e relato do trabalho de campo; dos dilemas enfrentados pelo pesquisador; do trabalho etnográfico, ou de abordagem etnográfica, evidenciando peculiaridades na tentativa 
de compreender o Outro (ROSISTOLATO, 2007). Dessa maneira, ainda na esteira do pensamento do autor, compreender o Outro é compreender a si mesmo rompendo fronteiras, por vezes tão fixas e sem sentido.

Pensar nas questões éticas em pesquisa é refletir sobre a própria ação do pesquisador no campo pesquisado e sobre o objeto de estudo. Dessa forma, em muito as pesquisas de abordagem etnográfica vêm possibilitando tal ação, devido à sua dimensão cultural envolvendo os sujeitos da investigação. Destaca-se o compromisso com a confidencialidade dos sujeitos e instituições, assim sendo, os nomes aqui apresentados serão fictícios.

As vozes dos participantes da pesquisa são evocadas, por meio de entrevistas e na produção textual sobre a escola, mas não em um sentido de ilustração, ou seja, de mera corroboração para algo já existente. Antes de tudo, parte-se de tais vozes para se construir uma teorização com/para os jovens que estão presentes na escola (MATTOS; ALVES, 2015), uma teorização de como os jovens-estudantes se relacionam com o conhecimento escolar produzindo, dessa forma, as categorias etnográficas da pesquisa. A seguir debateremos o conceito de juventude e como sua relação com o futuro atravessa a escola no tempo presente mediados pelos processos educacionais.

\section{AS JUVENTUDES E O FUTURO QUE ATRAVESSAM A ESCOLA}

A partir da ideia de processos educacionais e da perspectiva do/a aluno/a, que pensamos em Dayrell (2010) ao problematizar o conceito de juventude e a ideia de socialização juvenil a partir do contexto do ensino no Ensino Médio.

Parte-se da ideia de se trabalhar com a condição juvenil, "por considerá-la mais adequada aos objetivos desta discussão" (DAYRELL, 2010, p. 67). Tal categoria refere-se à condição de ser, a modos de agir, pensar e sentir dos jovens e suas vidas na sociedade. Tal condição juvenil se assenta nas perspectivas de mudanças ocorridas, principalmente, com as transformações do espaço-tempo, tecnologias, sistemas integrados de informação e comunicação etc. O ser jovem 
hoje assume um aspecto fluido, de deslocamentos, ou mesmo, de performances cotidianas (PAIS, 2006).

Dayerrll (2003, 2007, 2010), também, evidencia que há múltiplas dimensões da condição juvenil na atualidade, a saber, o trabalho, as culturas juvenis, a sociabilidade, o espaço-tempo, a transição para a vida adulta, as mudanças no processo de socialização, a relação entre os jovens e a escola e, por fim, os jovens, a escola e o ensino. $O$ autor também afirma:

"... entendemos juventude como parte de um processo mais amplo de constituição de sujeitos, mas que tem especificidades que marcam a vida de cada um. A juventude constitui um momento determinado, mas não se reduz a uma passagem; ela assume uma importância em si mesma. Todo esse processo é influenciado pelo meio social concreto no qual se desenvolve e pela qualidade das trocas que este proporciona" (DAYRELL, 2003, p. 42).

Há uma discussão sobre o mundo da cultura e culturas, as identidades juvenis como constituição de pertencimento, a relação dos jovens com as tecnologias e as formas de lazer. É possível pensar em termos tais como indústria cultural, grupos culturais, galeras e gangues, movimentos jovens, produção cultural etc. Aliada a tais questões, de igual forma, o autor relaciona temas que se coadunam com a configuração espacial das cidades brasileiras, instituições hegemônicas e uma possível "crise de autoridade".

De acordo com Miguel (2013, p. 36): "Presenciam-se na vida contemporânea impasses e avanços de uma juventude que se vê desamparada diante da insuficiência de dispositivos sociais que lhe indiquem um lugar que deva ocupar". Contudo, a mesma autora afirma, que "a imagem da juventude é cada vez mais usada como um ideal" (ibidem). Defende-se, aqui, a ideia de juventude em trânsito, com seus deslocamentos e rasuras no presente e no futuro, para indicar os movimentos acelerados ou paralisados pelos quais a juventude perpassa. Uma juventude que viva na escola nos toma de assalto para pensar suas relações com o conhecimento escolar (BORGES, 2021). 
Abordam-se os processos educacionais, assumindo-se o entendimento de que tais processos estão relacionados com currículos, didáticas, avaliações, conhecimentos e subjetividades. Argumenta-se que tais demandas, presentes na escola, proliferam uma gama de sentidos para o que seria a função social da própria escola, retomando uma questão de fundo sociológico. Não há uma escola, mas processos que permeiam a instituição escolar e que vão constituindo o que seria educar em tempos como os de hoje.

As vozes abaixo, de jovens-estudantes da pesquisa, evidenciam dimensões que atravessam o próprio sentido da juventude e do futuro. As produções textuais, também, revelam a escola como lugar de disputa possível no mundo hoje relacionada aos direitos sociais e ao mundo trabalho. Chica e Zezé, como já anunciado anteriormente são nomes fictícios, dão o tom para pensarmos as contradições, desejos e aspirações com/para/na escola de hoje.

Na escola aprendi a importância dos números, da leitura e compreensão, e da educação, que nada cai do céu. Que os diretores lutam por uma escola melhor e muitos diretores não têm o respeito e a compreensão (Produção textual da aluna Chica, de 15 anos, da $2^{a}$ série do E.M.).

Espero poder me graduar em Direito, me especializar na área de advocacia ou magistratura, e posteriormente me aquilatar em Biologia. Espero poder exercer minha profissão, fazendo o que gosto de fazer e dando o melhor de mim (Produção textual da aluna Zezé, de 16 anos, da $2^{a}$ série do E.M.).

A partir das falas acima podemos pensar se a escola tem futuro. Tal questão é problematizada por dois autores, Costa (2007) e Canário (2006), que trazem ao debate uma centralidade da escola na vida moderna, ou mesmo, pós-moderna. Questão com muitas respostas possíveis. Contudo, coloca-se em relevo aqui não nas respostas, mas na própria pergunta em sua relação escola-futuro.

A primeira autora, Costa (2007), em diálogo com diferentes intelectuais do campo educacional no Brasil, argumenta que a escola, nascida como instituição do século XV, vem enfrentando, ao longo do tempo, um conjunto de transformações sociais que perduram hoje numa reflexão acerca de ser: i) uma escola que 
assegura a todos a formação cultural e científica; ii) uma escola que tem a função de garantir justiça social; iii) uma escola que é arrolada no cotidiano; iv) uma escola que deve garantir a manutenção das conquistas da modernidade; v) uma escola que garanta direitos à educação; vi) uma escola que nos ajude a formar sujeitos numa perspectiva cidadã. Embora não haja um consenso sobre o lugar em que chegará a instituição escolar, há uma compreensão de que a escola parece ser, também hoje, algo central na vida das sociedades e das pessoas.

O segundo autor, Canário (2006), indica que não é possível prever o futuro da escola. Todavia, é possível problematizar a sua construção temporal numa perspectiva de reflexão crítica para que o mesmo futuro seja resultado de uma construção pautada num projeto de sociedade. Ou seja, para pensar e transformar a escola é preciso que i) se pense a escola fora dos muros escolares; ii) que o trabalho escolar seja o trabalho de aprender a viver uma construção; iii) que se pense a escola em consonância dos movimentos sociais. Em suma, é preciso assumir uma postura crítica pra se pensar a "crise da escola" viabilizando uma mudança com o mundo.

A ideia de futuro, ainda durante a pesquisa de campo, emerge em uma dupla transitividade: o futuro como temporalidade e o futuro como emergência e imaginação das relações sociais dos jovens com o conhecimento escolar e a própria escola. Os sentidos de futuro tornam-se categoria no campo etnográfico, precisamente por se relacionarem à imaginação, criação, narrativa e subjetividade. Aguça-se o olhar para as muitas vias investigativas que emergem dos sentidos de futuro, pensando, a partir dos jovens-estudantes do Ensino Médio, a ideia de presentificação da vida cotidiana. O futuro no arcabouço etnográfico traçado pelos jovens estudantes se enuncia como o hoje e o agora, mas também o amanhã, destacando a simultaneidade temporal e espacial do sujeito no mundo.

Para o meu futuro, depois da escola, faculdade de administração ou contabilidade. E senão der certo quero fazer faculdade de direito, mas quero começar de baixo, pois como minha mãe diz: "na vida temos que começar por baixo para crescer na vida" (Produção textual da aluna Rayla, 17 anos, $3^{\mathrm{a}}$ série do E.M.). 
A fala de Rayla emerge como leitura possível de um presente que é movimento "ao começar de baixo para crescer na vida". A materialidade, o imediatismo, a rapidez, a tecnologia, entre outras demandas, passam a ser temáticas relacionadas aos processos educacionais, pois interferem na relação estudante-conhecimento escolar. Há movimentos, no plural, que indicam essa dupla transitividade, do futuro e da escola, como categorias na vida do jovem-estudante do Ensino Médio da escola pesquisada.

De acordo com dados da pesquisa, foi questionado aos jovens o que esperar do futuro. Suas narrativas, a partir das entrevistas etnográficas, revelam emergências possíveis do que desejam os alunos e alunas do Ensino Médio. Revelam subjetividades e evidenciam uma reflexividade da condição juvenil, como demonstram as narrativas abaixo. As entrevistas etnográficas são entendidas, em diálogo com Mattos (2008), como uma abordagem de cunho político-teórico e crítico, ou seja, pauta-se numa ideia que parte dos atores sociais para construção de teorizações a partir de uma escuta aberta e sensível. Ancora-se na observação participante para propor perguntas abertas e que dialoguem com a realidade social da pesquisa.

O tempo parece ser um caminho possível para a compreensão das relações sociais, por exemplo, com a explicação: "espero me formar e ter um emprego". Porém, há subjetividades latentes que precisam ser compreendidas ao propor uma forma de pensamento em que o sujeito se relaciona com o Outro e consigo mesmo. O tempo passa ser, então, imaginação de um futuro possível, às vezes impossível, e também desejo de realidade material concreta, necessária e palpável. Seriam o futuro e o tempo formas de conhecimentos silenciadas na escola?

As vozes revelam que é possível um empreendimento necessário na compreensão de que o futuro seja espaço-tempo de imaginação e contradição, "Que seja melhor do que o presente ou o passado", conforme fala de um estudante. Talvez, traga um quê de transformação da realidade social em que estes jovens-estudantes do Ensino Médio estejam inseridos. Sobretudo, pensando à 
realidade da Escola Alvorada, em Nova Iguaçu, Baixada Fluminense, no estado do Rio de Janeiro.

As questões arroladas, acima, sinalizam para o entendimento de uma demanda sobre o papel da escola na construção da esperança. A esperança no futuro, segundo Bhabha (2011), também é a possibilidade da emergência de novas formas de compreensão das relações sociais. Contraditoriamente, as palavras de Leona sinalizam o lugar do medo: "E o medo de crescer com a ignorância me apavora, pois, o mundo está cheio de ignorância e de forma bem ilimitada". Contudo, é o medo da ignorância que disputa sentido, aqui, com a ideia de conhecimento. Talvez resida nessa relação, ignorância versus conhecimento, o desafio da escola moderna presente nos dias de hoje, na medida em que se compreende a ignorância, não como um espaço-tempo vazio de saber, mas tentando perceber quais sentidos damos à ignorância, ou mesmo, ao ignorante, no ambiente escolar.

Bhabha (2011) sinaliza que o futuro se torna uma questão social aberta, uma vez que tal categoria é um interstício que emerge do entrelugar do passado com o presente. A disputa pelo futuro também pode ser a disputa pela identidade de si. O futuro surge como possibilidade de esperança, tal qual como evidenciado pelos jovens-estudantes na escola pesquisada.

O desejo de um futuro com mais oportunidades e sem desigualdades sociais, culturais, de gênero, sexualidade e raciais, talvez seja um indicativo das fronteiras que a escola precisará ultrapassar para se pensar como instituição sob rasura (HALL, 2006). O debate, fraturado e não superado, resiste nas vozes discentes da investigação.

\section{À GUISA DE CONCLUSÃO}

Ao fim e ao cabo, as categorias definidas na pesquisa e os fragmentos das vinhetas etnográficas analisados aqui, sustentam os resultados desse estudo ao relacionar os sentidos produzidos pelos jovens, alunos e alunas, com o conhecimento escolar numa perspectiva de trabalho com o futuro. Tais questões nos fazem pensar no lugar de pertencimento que se vive no dia a dia da escola e da resiliência que os alunos criam 
ao se relacionarem com a instituição etc. Desse episódio fica claro que a pesquisa de campo não tem momento certo para começar e acabar. Esses momentos são arbitrários por definição e dependem, hoje que abandonamos as grandes travessias para ilhas isoladas e exóticas, da potencialidade de estranhamento, do insólito da experiência, da necessidade de examinar por que alguns eventos, vividos ou observados, nos surpreendem. E é assim que nos tornamos agentes na etnografia, não apenas como investigadores, mas nativos/etnógrafos. Essa dimensão incita ao questionamento da etnografia como método (PEIRANO, 2014, p. 379).

O texto proposto por Peirano (2014) indica uma questão emblemática nas pesquisas etnográficas: a pesquisa de campo não tem um momento certo pra começar, ou acabar, mesmo sabendo que, paradoxalmente, ela tenha um começo e um final.

A pesquisa em tela foi realizada com os estudantes das turmas do $2^{\circ}$ e $3^{\circ}$ anos do Ensino Médio da Escola Alvorada, no estado do Rio de Janeiro, juntamente, com a parceria do professor de Química que participou da investigação na condição de colaborador. Um dos pressupostos da abordagem etnográfica seria exatamente a ideia de colaboração com o Outro. Tal ação, também, versa sobre uma forma de "devolução" da pesquisa aos sujeitos e às instituições pesquisadas participantes do estudo.

No último dia de observação participante na escola, foi entregue e apresentada aos estudantes, ao professor e à direção uma síntese, que continha pistas de como caminhou a pesquisa.

Chego na escola $7 \mathrm{~h}$ e $20 \mathrm{~m}$ e vou para sala de aula. Chove bastante. Falo com o professor Ricardo e com a turma, é o último dia da pesquisa. Apresento os resultados e os alunos comentam, perguntam sobre o ENEM. Entrego um resumo da pesquisa em uma folha como se fosse um minilivro. Eles dão uma lida e comentam: "nós falamos tudo que tá aqui". Uma aluna diz: "me identifico com o futuro, menos com o tráfico". Outro aluno, Wagner, pergunta quando ficará pronta a tese. Eu digo que ficará pronta em dois anos. Ele diz, bom. Luiz Felipe, que fez o grafite para a pesquisa, ficou muito feliz com o livreto porque o desenho era dele. Mostrou para todos os colegas de sala dizendo que ele tinha feito. O professor aplicará uma prova, eles se organizam, fico na sala para observação... (Relatório de Campo 17 - 01/12/2015). 
As perguntas dos estudantes foram muitas no sentido de um futuro possível: o Exame Nacional do Ensino Médio (ENEM) ${ }^{1}$, algo iminente na vida dos jovens-estudantes, se faz presente e questionável. É interessante perceber que os jovens se reconheceram no texto: "nós falamos tudo que tá aqui”. Uma aluna diz: "me identifico com o futuro, menos com o tráfico". O processo de descrever densamente gerou um espelhamento capaz de permitir uma identificação com a leitura proposta pelo pesquisador.

Fazer pesquisa em educação exige uma posição política sobre as relações estabelecidas dentro das instituições. Acredita-se que fazer, estar ou participar de pesquisa é um importante percurso no espaço-tempo para o amadurecimento da condição de sujeitos no mundo. Essa condição se relaciona com a escola básica brasileira, em especial com a escola pública. Ao se percorrer o itinerário dessa investigação, foram desenvolvidas reflexões caras à produção de conhecimento no campo da educação.

O papel da pesquisa e do pesquisador foi questionado durante todo o tempo. Só conhece alguém, ou alguma coisa, quem duvida. E porque há dúvidas, aprende-se cotidianamente. A etnografia - escrita do Outro, mas também de nós mesmos - possibilitou, em uma perspectiva cultural, que o diálogo se realizasse. Nesse momento, a ideia de um mediador, assim como aprendido com Gilberto Velho em seus escritos sobre Antropologia, ou mesmo de um griô, que narra suas memórias para manter viva a cultura de seu povo, vem à tona. Seria o pesquisador um griô que narra mediações de mundos existentes?

Por fim, fazer mediação entre a escola e a universidade foi um desafio. Ao desenvolver essa mediação foram atravessados alguns mundos possíveis que aqui foram narrados. Fazer uma travessia é sempre instigante, pois não se pres-

1 De acordo com o Ministério da Educação: "O Exame Nacional do Ensino Médio (Enem) foi instituído em 1998, com o objetivo de avaliar o desempenho escolar dos estudantes ao término da educação básica. Em 2009, o exame aperfeiçoou sua metodologia e passou a ser utilizado como mecanismo de acesso à educação superior. Desde 2020, o participante pode escolher entre fazer o exame impresso ou o Digital, com provas aplicadas em computadores, em locais de prova definidos pelo Inep". Disponível: https://www.gov.br/inep/pt-br/areas-de-atuacao/avaliacao-e-exames-educacionais/enem 
supõe os achados ao final do caminho, sempre estamos à deriva. Enfim, a arte de pesquisar envolve um emaranhado de fios que, ao longo dessa jornada, foram tecidos em colaboração com um professor, uma escola e duas turmas de Ensino Médio. É preciso, ao pesquisar, saber que ao final da travessia há um processo de se tornar agente na etnografia, não apenas como investigador, mas, nas palavras de Peirano (2014), já como nativo/ etnógrafo.

\section{REFERÊNCIAS}

BHABHA, H. O Bazar Global e o Clube dos Cavaleiros Ingleses. Rio de Janeiro: Editora Rocco, 2011.

BOURDIEU, P. Questões de sociologia. Rio de Janeiro: Marco Zero, 1983.

BORGES, L. P. C. O futuro da escola: (re)imaginando uma etnografia sobre a relação dos jovens estudantes com o conhecimento escolar. 1ed. Curitiba: Appris, v. 1, 2021.

CANÁRIO, R. A escola tem futuro? Das promessas às incertezas. Porto Alegre: Artmed, 2006.

COSTA, M.V. A escola tem futuro? 2 ed. Rio de Janeiro: Lamparina, 2007.

DAYRELL, J. A juventude no contexto do ensino da sociologia: questões e desafios. IN: Sociologia: ensino médio (Coleção Explorando o Ensino). 1ed.Brasilia: MEC Secretaria de Educação Básica, v. 15, p. 65-85, 2010.

DAYRELL, J. A escola "faz" as juventudes? reflexões em torno da socialização juvenil. Educação e Sociedade, Campinas, vol. 28, n. 100, especial, jul./dez. p. 1105-1128, 2007. Disponível em: https://www.scielo.br/j/es/a/RTJFy53z5LHTJjFSzq5rCPH/?format=pdf\&lang=pt. Acessado em 18/07/2020.

DAYRELL, J. O jovem como sujeito social. Revista Brasileira de Educação, n.24, set./out./nov./dez. p. 40-52, 2003. Disponível em: https://www.scielo.br/j/rbedu/a/ zsHS7SvbPxKYmvcX9gwSDty/?format=pdf\&lang=pt Acesso em 01/06/2020.

HALL, S. A identidade cultural na pós-modernidade. Rio de Janeiro, 11ed, DP\&A, 2006. 
IPEA - INSTITUTO DE PESQUISA ECONÔMICA APLICADA. Millennials na América e no Caribe: trabalhar ou estudar?. Brasília: Ipea, 2018. Disponível:https://www.ipea.gov.br/portal/index.php?option=com_content\&view=article\&id=34460 Acesso em 02/02/2020.

LÜDKE, M.; ANDRÉ, M. E. D. A. Pesquisa em Educação: abordagens qualitativas. São Paulo: EPU, 1986.

MATTOS, C. L. G. ALVES, W. B. Outros saberes sobre a escola: a voz do aluno na pesquisa em educação. In: Maria do Socorro Lucena Lima; Maria Marina Dias Cavalcante; José Albio Morreira de Sales; Isabel Maria Sabino de Farias. (Org.). Didática e prática de ensino na relação com a escola. 1ed.Fortaleza: EdUECE, v. 1, p. 03435-03446, 2015.

MATTOS, C. L. G. de. Fracasso Escolar: Gênero e Pobreza (2008-2011). Projeto de pesquisa. Faculdade de Educação, UERJ/ CNPq Universal, p. 105, 2008.

MIGUEL, A. M. Laço da laje: jovens produtores de cultura. Dissertação (Programa de Pós-Graduação em Educação, Cultura e Comunicação, da Faculdade de Educação da Baixada Fluminense) da Universidade do Estado do Rio de Janeiro, p. 79, 2013.

PAIS, J. Buscas de si: expressividades e identidades juvenis. In: ALMEIDA, M. I. M; EUGENIA, F. (Orgs.) Culturas jovens: novos mapas do afeto. Rio de Janeiro: Zahar, p. 07-24, 2006.

PEIRANO, M. Etnografia não é método. Horizontes Antropológicos, n. 20, vol.42, p. 377-391, 2014. Disponível em: https://www.scielo.br/j/ha/a/n8ypMvZZ3rJyG3j9QpMyJ9m/?format=pdf\&lang=pt Acesso em: 08 de maio de 2020.

ROSISTOLATO, R. P. R. Orientação sexual com “jeitinho" Brasileiro: uma análise antropológica da intervenção escolar na socialização afetivo-sexual dos adolescentes. Rio de Janeiro: UFRJ/IFCS, 2007. 


\section{dol $10.48209 / 978-65-J U V E N-40-8$}
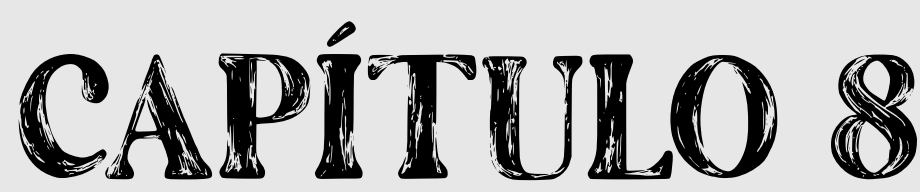

\section{EDUCAÇÃO FÍSICA ESCOLAR PELA}

REPRESENTAÇÃO DE JOVENS NO ENSINO MÉDIO

Brunna Thais Reis Sales Cláudia Valente Cavalcante 


\section{INTRODUÇÃO}

Em 2016, o presidente do Brasil, Michel Temer, sancionou a (Lei $\left.n^{\circ} 13.415\right)$, conhecida como Reforma do Ensino Médio. A Reforma do Ensino Médio realizou mudanças em algumas partes da Lei da Educação, conhecida como Lei de Diretrizes e Bases da Educação Nacional (LDBEN) 9.394/96. Uma das alterações foi não atribuir a alguns componentes curriculares o ensino compulsório, dentre esses à Educação Física.

Por essa razão, surgiu o interesse em saber como pensam os jovens, na condição de estudantes do Ensino Médio, que são os maiores interessados pelo tema. Assim, foram se construindo as questões: qual a importância da Educação Física para os jovens do Ensino Médio? qual a representação social dos jovens acerca da relevância da Educação Física escolar para sua formação como cidadão?

Foi iniciada a pesquisa com objetivo de compreender as Representações Sociais (RS) da Educação Física escolar na perspectiva dos jovens do Ensino Médio. Além de investigar a relação entre a história e o conceito da Educação Física; entender a partir desse contexto histórico a atual situação em que se encontra a Educação Física escolar; apreender a percepção que os jovens têm acerca da Educação Física escolar.

O percurso metodológico da pesquisa trilhou a linha de pensamento do sociólogo francês Pierre Bourdieu. Para Bourdieu (2000), a pesquisa é algo sério, difícil e deve ser tratada com rigor, uma vez que a produção é algo trabalhoso, que se realiza pouco a pouco, por sucessivos retoques, correções, emendas e segue um conjunto de princípios básicos que orientam as opções.

A construção do objeto deve ser a operação mais importante na pesquisa organizada entre a teoria e a metodologia, por acreditar que não seja possível reencontrar o concreto combinando duas abstrações, ou seja, as construções técnicas mais empíricas são inseparáveis das opções mais teóricas. O autor cri- 
tica a hierarquia social dos objetos de pesquisa denominados como legítimos ou ilegítimos, dos quais se impõe a censura específica de um campo determinado que possa ser o próprio disfarce de uma análise puramente política

A definição dominante das coisas boas de se dizer e dos temas dignos de interesse é um dos mecanismos ideológicos que fazem com que coisas também muito boas de se dizer não sejam ditas e com que temas não menos dignos de interesse não interessem a ninguém, ou só possam ser tratados de modo envergonhado ou vicioso (BOURDIEU apud NOGUEIRA; CATANI 2015, p. 37).

Esse trabalho se deu em duas etapas: primeiro, pela revisão bibliográfica e segundo pela pesquisa de campo. Na primeira parte, foram realizados levantamentos bibliográficos em livros, artigos, teses e dissertações que tratam das categorias: jovens, Ensino Médio e Educação Física. E a segunda parte foi a realização da pesquisa de campo que se deu através da aplicação do questionário e de entrevistas com os jovens do Ensino Médio. Tanto o questionário quanto a entrevista foram conduzidos pela pesquisadora em uma escola da rede pública.

Mesmo não sendo a única, a entrevista é uma das principais técnicas das pesquisas qualitativas, por permitir que se estabeleça uma relação de interação entre quem pergunta e quem responde e uma capacitação imediata da informação desejada (LUDKE; ANDRÉ, 1986).

Ao se iniciar uma relação de entrevista é necessário buscar conhecer os efeitos que podem vir a ser produzidos no princípio, na maneira de apresentar a pesquisa, pelos estímulos dados, entre outros, com intuito de esclarecer o sentido que o pesquisado faz da situação pesquisa em geral, seus objetivos e as razões que o faz participar da troca. É o pesquisador que inicia e estabelece as regras, os objetivos e hábitos da entrevista, para reduzir ao máximo os efeitos que podem vir a exercer a violência simbólica. Assim, tal método científico deve ser tratado com respeito, confiança e compreensão (BOURDIEU, 1997).

O projeto para a pesquisa foi submetido ao Conselho de Ética em Pesquisa da PUC Goiás, foi aprovado e adquirido o protocolo 69428217.5.0000.0037. 
A partir de então, iniciou-se a segunda etapa da investigação, em uma escola estadual, em Goiânia, que atende jovens do Ensino Médio, no período matutino.

Foram selecionados 10 jovens para a entrevista, sendo cinco do sexo feminino e cinco do sexo masculino com faixa etária entre 15 e 18 anos. Aqueles com idade igual ou acima de 18 anos assinaram o Termo de Consentimento Livre e Esclarecido (TCLE), aqueles com idade menor que 18 anos assinaram o Termo de Assentimento e foi entregue aos mesmos um TCLE destinado aos seus responsáveis, solicitando a autorização para realizar a pesquisa de campo, contendo todas as informações necessárias sobre a pesquisadora e sobre a pesquisa.

\section{REPRESENTAÇÃO SOCIAL}

Analisar as Representações Sociais (RS) dos jovens, no Ensino Médio, sobre temas que estão em discussão na sociedade é o mesmo que o considerar como um ser social, histórico, mutável e que esteja, além de ser somente um aluno.

As Representações Sociais transitam e se cruzam através das conversas, dos comportamentos e dos encontros. Também são consideradas como uma ciência coletiva endereçada à explicação e à disposição do real. Seus conceitos possuem unidades e se aplicam em diferentes campos das atividades sociais (medicina, psicologia, política, etc.). Quando tais conceitos são recebidos são submetidos ao trabalho de objetivação (MOSCOVICI, 2012).

As pessoas buscam dar explicações sobre a sociedade e o universo. Cada um parte de suas próprias observações e depoimentos sobre os episódios correntes, julga a realidade para reconstituí-la e torná-la familiar (MOSCOVICI, 2012). As representações é uma representação de alguém, uma forma de conhecimento da qual aquele que conhece se coloca no lugar do que é conhecido.

Ao se familiarizar com o conhecimento, esse saber faz parte das conversas cotidianas, cada sujeito emite suas visões sobre o assunto e formula suas próprias conclusões sobre o tema. A finalidade não é avançar o conhecimento, 
mas "estar por dentro" dos conteúdos coletivos. "Desse trabalho, muitas vezes começado, repetido e deslocado de um ponto a outro da esfera, dos acontecimentos e surpresas que captam a atenção surgem as Representações Sociais (MOSCOVICl, p. 51, 2012)."

$\mathrm{Na}$ área das RS o importante é saber as razões da produção dos sistemas, e não "quem" os produz. Dessa forma, para se entender é necessário realçar que sua função é própria do social, que contribui para os processos de formação das condutas e orientações das comunicações sociais (MOSCOVICl, 2012). E para isso existem dois mecanismos fundamentais que compõem a Representação Social: a objetivação e a ancoragem.

O mecanismo conhecido como objetivação é um processo que liga ideias não-familiares com a realidade familiar. Busca materializar uma abstração, transformar a coisa em uma palavra ou em uma imagem. Assim, objetivar é descobrir e reproduzir um conceito em uma imagem, podendo acontecer a veneração desse símbolo, chegando à medida que a sua distinção com a realidade é esquecida. A imagem deixa de ser um conceito e passa a ser a réplica da realidade (MOSCOVICl, 2003).

O outro mecanismo é a ancoragem, um processo que busca fundamentar as ideias desconhecidas a alguma categoria familiar, transformando algo e o comparando com um padrão de categoria que identificamos como apropriada. É classificar e dar nome a alguma coisa (MOSCOVICI, 2003).

Esse processo de categorização de algo ou alguém é escolhido um modelo em nossa memória e se estabelece uma relação de dois polos, negativo e positivo sobre o tema (objeto, assunto, fenômeno, entre outros). Ao enquadrar em um dos polos, a ancoragem geralmente conduz as decisões para a generalização ou para a particularização.

Ao generalizar, existe uma diminuição das distâncias das características e é, comumente, usado em uma categoria que, quando positiva, acontece a aceitação; quando negativa, ocorre a rejeição. Ao particularizar, existe um aumento 
da distância dos objetos de análise, como algo que se diferencia de um modelo que possui características que é julgado para representar algo ou alguém (MOSCOVICI, 2003).

A objetivação e a ancoragem se tratam de dois processos cognitivos utilizados para conhecer algo novo e, quando esse "algo novo" ingressa no campo intelectual, desperta um conflito entre o medo do que não se conhece, cria uma resistência e a necessidade de conhecer escapa do controle daquele que já conhece (SPADONI, 2016).

A respeito da objetivação

A objetivação é um processo que faz essa novidade se tornar uma realidade conhecida para as pessoas. De maneira que, quando pensamos em algo, não temos que ter uma descrição desse objeto para saber o que é. Pelo contrário, quando escutamos uma palavra conhecida, imediatamente temos a consciência, ou mesmo uma imagem associada a essa palavra, que nos faz saber do que se trata (SPADONI, 2016, p. 84).

E a respeito da ancoragem

A ancoragem parte do princípio de que, quando um indivíduo pensa num novo objeto, ele não o pensa no vazio, como se sua mente fosse um quadro em branco. Pelo contrário, ele compara esse objeto com algo já conhecido e o categoriza dentro das complexas redes de conhecimento que já possui (SPADONI, 2016, p. 84).

Apesar de mencionados aqui de forma separados, os dois processos (objetividade e a ancoragem) não ocorrem de maneira isolada nas dimensões cognitivas das pessoas. Os sujeitos se comunicam uns com os outros e vão compreendendo as ideias de forma social. Essa compreensão utiliza a arquitetura do pensamento social através dos conceitos opiniões, atitudes, valores e normas (SPADONI, 2016).

Spadoni (2016) entende que as opiniões são mais fáceis de serem mudadas e se baseiam nas atitudes. As atitudes são sistemas mais duradouros de avaliações positivas ou negativas, que se relacionam com os componentes afetivos, cognitivos e comportamental. Os valores humanos são fundamentais em todas as culturas por corresponder às exigências universais das necessidades 
biológicas, de coordenação interindividual e da necessidade de continuidade da sociedade, se desdobrando posteriormente em normas. As normas passam a ser vistas como regras de aplicação e de preservação dos valores que são reconhecidos em prescrição de comportamentos (SPADONI, 2016).

Dessa forma, a Representação Social é compartilhada por várias pessoas que pensam da mesma forma sobre qualquer assunto, indicando como os sujeitos poderão agir em diferentes acontecimentos sociais. Por isso, torna-se necessário estudar para perceber a trajetória que o pensamento social está percorrendo sobre determinado tema em um grupo específico.

A presente pesquisa justifica-se acerca da visão que os jovens do Ensino Médio possuem sobre as funções da Educação Física no ambiente escolar e sobre as mudanças que a Reforma pode tomar e atingir aqueles que estão em fase de formação educacional formal.

Mesmo considerando que as pessoas pensam de forma ativa e independente, as ferramentas que o sujeito possui apresentado pela cultura, suas atitudes e opiniões ficam ancoradas naquilo que o seu grupo, sociedade e cultura the apresentam como recursos para se posicionar acerca de determinados temas.

Portanto, os jovens de diferentes gerações construíram suas representações no decorrer da história da mesma forma que a Educação Física se solidificou ao longo dos anos a partir dos interesses conferidos social e culturalmente.

\section{EDUCAÇÃO FÍSICA ESCOLAR}

A Educação Física é a área do conhecimento que tem como objeto de estudo o movimento do corpo humano e é objeto de investigação tanto das ciências biológicas quanto das ciências humanas e sociais. Isso significa, respectivamente, que além do campo ser visto através do viés técnico e mecanizado também carrega sentidos e significados simbólicos e culturais.

A sistematização dos movimentos do corpo iniciou na modernidade, quando o objetivo era a construção de um novo corpo, um novo homem higie- 
nicamente forte e saudável, porém não-pensante e incapaz de criticar as estruturas e ações sociais, cujos interesses se vinculavam ao capital e ao lucro. Foi no século XX que a Educação Física recebeu influência das ciências humanas e sociais, passando a ser vista pelo olhar pedagógico, ampliando a concepção de ser humano e avançando o conhecimento da área em relação ao sujeito como um ser sociocultural.

Autores como Freire (1989), Coletivo de Autores (1992), Kunz (1991), Betti (1991) e outros se opuseram à visão mecanicista e tecnicista da Educação Física no interior da escola e advogaram pelo desenvolvimento das habilidades biopsicomotoras dos sujeitos.

A Educação Física ainda é uma área que busca a consolidação de sua identidade própria. Recebe diferentes concepções porque ora é recrutada pelas ciências da saúde ora é requisitada pelas ciências educacionais posicionando-se como objeto de disputa entre esses dois campos.

A ideia de campo citada está fundamentada em Bourdieu que o entende como espaços estruturados de posições cujas propriedades dependem da distribuição dessas posições nestes espaços, podendo ser analisadas independente das características daqueles que os ocupam. Ou pode ser caracterizado através da definição de disputa dos objetos e dos interesses específicos (BOURDIEU, 1983).

E no cenário de disputas nada é mais competitivo do que o universo esportivo, um campo que Bourdieu tira da marginalidade, como algo atribuído somente ao lúdico, e lhe destina a importância de ser investigado (RIBEIRO, 2016).

Desde sua chegada no Brasil, na forma de Método Tradicional de Ginástica com os objetivos higienista, militarista e eugenista, a Educação Física foi recebendo diferentes finalidades de emprego nos âmbitos em que era inserida. Nos quartéis era vista como um meio de fortalecer as tropas militares e para a defesa da pátria. Para os civis era vista como uma maneira de educar o corpo, o espírito 
e a moral dos cidadãos, além de posturas higienistas e eugenistas para com a população (SOARES, 2012).

No âmbito escolar, diversas concepções foram adotadas ao longo do tempo: com bases militaristas, tecnicistas, esportivistas e/ou recreacionistas; vista como um instrumento de auxílio para o desenvolvimento cognitivo dos alunos e, mais recente, como responsável pela ampliação da cultura corporal daqueles que a praticam (DARIDO; RANGEL, 2014).

O recreacionismo ${ }^{1}$ se configurou como a extensão do recreio, o que em outras palavras, é aquela aula em que o aluno decide o que quer fazer e o professor se limita a marcar o tempo de 45 minutos da aula. $O$ esportivismo se caracterizou por utilizar as aulas de Educação Física, nas escolas, como treinos para os alunos mais aptos fisicamente em função dos esportes de alta performance, em especial, o futebol, o vôlei, o basquete e o handebol. Nesse contexto, os alunos que não têm estrutura física e o interesse em se tornar atleta de alto rendimento ficam excluídos das aulas escolares (DARIDO; RANGEL, 2014).

Mais recentemente, os pesquisadores da Educação Física inseriram a cultura como forma de analisar a função e a importância do componente curricular no interior da escola. Assim, surgiram abordagens pedagógicas que defendem a Educação Física escolar em prol da ampliação da cultura corporal.

O Coletivo de Autores (1992) vê a Educação Física escolar com o objetivo de desenvolver a cultura do corpo do ser humano, abordando conceitos e sentidos que se relacionam com os objetivos do homem e da sociedade, considerando esse homem como um ser social, histórico e cultural. Daolio (2010) entende que a Educação Física lida com os conteúdos culturais de uma sociedade e o

1 Termo usado para representar as aulas de Educação Física que os alunos decidem o que fazer, como se fosse uma extensão do recreio. Essa "estrutura" de aula começou a ser usada quando a Educação Física recebeu a influência das ciências humanas e criticou o modelo esportivista. Com grande quantidade de alunos em sala, culturas corporais heterogêneas, se tornaria impossível produzir bons atletas de alto nível no ambiente escolar. Por outro lado, as pedagogias com concepções humanistas estavam em processo de construção e poucos tinham sua devida compreensão. Assim, as aulas foram deixadas "livres" (DARIDO; RANGEL, 2014). 
profissional trata do ser humano nas suas manifestações culturais relacionada com o movimento do corpo específico no contexto ao qual se realiza.

É difícil ver a definição exata da especificidade da Educação Física vindo da comunidade escolar. Quando Darido (2003) questiona: qual é o objetivo da Educação Física Escolar? Normalmente, as respostas para a questão é que a disciplina serve para "jogar bola", aprender sobre os esportes, "fazer nada" ou brincar (o brincar, nesse contexto, se refere às brincadeiras sem orientação profissional).

Essas são as respostas que se encaixam nas Representações Sociais que as pessoas destinam ao atribuir a função da Educação Física escolar, ou seja, como se fosse, exclusivamente, responsável pela prática dos treinamentos esportivos e pela recreação, ócio e/ou lazer, despreocupada das intervenções pedagógicas que o campo tem a contribuir com a emancipação do ser que a pratica (BARBOSA, 2001).

\section{JOVENS E REPRESENTAÇOES ACERCA DA CATEGORIA}

Investigar sobre os jovens é descortinar muitas representações que a sociedade destina a esse grupo social como se fossem verdades absolutas e imutáveis. É entender que existem várias formas de ser jovem e de juventudes que possuem histórias, sentimentos e culturas que são produzidas a partir da realidade em que se inserem mas que vivem de forma singular.

As Representações Sociais mais comuns destinadas aos jovens são, por um lado, há alto vigor físico, jovialidade, disposição, curtir a vida sem preocupações, a beleza e o romantismo; por outro lado, há a relação com comportamentos inadequados, aproximação com drogas, delinquência, rebeldia, entre outras. Entretanto, raramente, são atribuídas representações aos jovens como produtores de cultura, pensantes e ativos.

Dayrell (2003) considera que a juventude não deve ser entendida como uma fase da vida como singular, padronizada e homogênea, mas como uma con- 
dição social que faz parte de um processo mais amplo em que os sujeitos estão em transformação durante a vida.

Guimarães (2002) entende que a juventude é o período da vida ao qual os indivíduos estão entre 15 e 24 anos de idade. É uma categoria em que os sujeitos estabelecem relações sociais, econômicas, políticas e culturais ativas, e utilizam de várias estratégias de inserção no mundo social (CAVALCANTE, 2011).

No âmbito da pesquisa acadêmica, as investigações acerca dos jovens se limitavam a refletir sobre as situações problemas ou formular políticas públicas destinadas a esse público. Só, recentemente, as pesquisas começaram a dar voz aos jovens enxergando-os como sujeitos capazes de problematizar e propor ações relevantes no processo para solucionar os problemas sociais aos quais estão relacionados (ABRAMO, 1997).

Conhecer os jovens, como eles pensam, suas histórias de vida, como sentem é fundamental para avançar o conhecimento sobre a categoria. Afinal, são seres capazes de refletir por si próprio e em relação ao ambiente ao qual fazem parte.

Assim, 10 jovens participaram desse trabalho e serão apresentadas as respostas adquiridas de acordo com as questões feitas nos questionários e nas entrevistas. A entrevista buscou apreender o que os jovens pensam sobre a educação física bem como a sua importância no âmbito escolar.

\section{JOVENS E AS REPRESENTAÇÕES SOCIAIS ACERCA DA EDUCAÇÃO FÍSICA ESCOLAR}

A educação brasileira é composta pela educação básica e pela educação superior. A educação básica é formada pela Educação Infantil, Ensino Fundamental e Ensino Médio. Dentre os componentes curriculares que compõem o Ensino Médio, a Educação Física está presente na grade curricular. 
A pergunta feita aos jovens, no Ensino Médio, era se eles gostavam de participar da disciplina de Educação Física escolar.

As respostas indicaram que sim, gostam das aulas, mas alguns jovens questionam a legitimidade da Educação Física na escola devido à postura de alguns professores em usar as aulas no estilo recreacionismo e por causa da infraestrutura das escolas.

J1- "Gosto. Eu participo bastante das aulas. Eu acho que a EFE é um modo de fazer as pessoas não ser tão sedentárias, praticar esporte e ter uma vida saudável."

J2- "Gosto. Às vezes. Ela é importante, eu acho que deve ter muito aluno querendo se formar nessa área. Ai eu acho que não deveria ser obrigatória, mas também não tinha que tirar".

J3- "Eu acho que a EF não é importante dentro da escola, porque se você parar pra pensar, a maioria das escolas públicas os professores entregam a bola e os meninos saem fazendo o que eles querem nas aulas. Ai acaba tornando uma coisa sempre chata, porque você não aprende coisas novas. O professor fica só sentado".

J4- "Gosto, bastante. Faço, quando venho pra escola".

J5- "Gosto. Faço. Eu acho que a EF dentro da escola é importante. Porque ela estimula o aluno ao exercício físico, pra combater o sedentarismo. As pessoas hoje estão muito sedentárias".

J6- "Gosto. Faço. Eu acho que a EF deveria estar dentro da escola. Porque ela ensina o jogo, as regras, a história, inclui tudo até a Biologia".

J7- "Gosto, mas quase não faço nada na aula de EFE. Porque eu sinto vergonha de mim (por não ser magro)".

J8- "Gosto, principalmente o vôlei. Faço. Eu acho que a EFE é importante. É bom pra desenvolver os músculos, saber qual a alimentação adequada pra gente".

J9- "Gosto. Faço. Pra falar a verdade eu nunca parei pra pensar pra que serve a EF na escola. Eu não sei".

J10- "Não gosto da forma que ela é dentro da escola. O governo não dá estrutura pra escola. Eu vivo realidade, o Brasil não tem estrutura pra isso. Falta professor, falta estrutura. Em minha opinião, nenhuma disciplina deveria ser obrigatória, cada um deveria fazer sua grade de estudo. Porque tem pessoas que só quer brincar, tem pessoas que quer focar no esporte". 
A outra pergunta feita foi se eles consideravam a Educação Física importante na escola. Os argumentos vieram com a confirmação de que o componente curricular é importante. Disseram que a disciplina distrai a mente, aprende sobre os esportes e é um espaço de socialização.

J1- "Eu acho que a EFE é importante porque junta os alunos, às vezes um é novato pode se misturar e pode conversar com os alunos. Porque, geralmente, a EFE é sempre praticada em grupos".

J2- "Eu dou muita importância a EFE, porque tem gente que fica em casa o dia inteiro, não faz nada. Ai quando chega aqui até anima de fazer alguma coisa. Eu acho importante".

J3- "A EFE na concepção de que os professores passassem coisas novas e ensinassem os alunos, ai sim é importante. Ai faz sentido. Ela deixa as pessoas mais próximas. Porque na sala fica um de um lado, um do outro lado. E ela consegue enturmar todo mundo. É mais voltada pra socializar os alunos.

J4- "Pra mim EFE é um tempo para os alunos aprender sobre o esporte. O esporte começa na escola".

J5- "O sentido da EFE é que a aula pratica seria mais pra distrair, pra quebrar o clima pesado de só estudar".

J6- "Porque ela ensina o jogo, as regras, a história, inclui tudo até a Biologia. Ela ensina cada parte, cada músculo, ensina muita coisa, explica. A questão das Olimpíadas, ensinou a história do jogo. Por isso o professor de EF é importante, é ele que vai me ensinar, que tem o estudo suficiente pra me ensinar.

J7- "Eu acho que a EFE é importante, por causa dos exercícios, ter um descanso das outras aulas. Porque só aula de escrever, às vezes cansa muito. Ai na aula de EF acaba descontraindo".

J8- "Eu acho que a EFE é importante. É bom pra desenvolver os músculos, saber qual a alimentação adequada pra gente. E é muito bom isso na EF. Porque hoje em dia o povo não para pra pensar na alimentação, fazer exercícios".

J9- "Acho que a EFE deveria ser pra gente se exercitar, porque a gente fica seis aulas sentados dentro da sala. Acho que seria mais pra gente se 
movimentar, não ficar parado aqui dentro".

J10- "Eu sou a favor da EF na escola. Eles querem tirar as disciplinas que aparentam não ter peso, mas tem um peso pra pessoa. A EFE é importante, faz você ser competitivo, faz você querer cuidar do seu corpo, ter outras ideias".

Os jovens participantes da pesquisa reconhecem a importância da Educação Física na escola para evitar o sedentarismo, para socializar os alunos e para estudar sobre os esportes. Dois alunos apresentam opiniões acerca da predominância dos esportes coletivos nas aulas de Educação Física, com o seguinte sentido:

J4- "Eu mudaria nas aulas para passar mais esportes, praticar outras coisas, diversidade, sabe. As lutas ainda não têm, a natação que é muito importante não tem, e temos três piscinas aqui desativadas. Sempre o mesmo esporte já ta ficando chato".

J4- "deveria ensinar outras coisas, a maioria dos colégios só ensinam futebol, futebol, futebol, vôlei, futebol. Não mudam muito as coisas".

J9- "se eu for jogar bola lá, eles nem passam a bola pra gente que é menina".

As falas dos jovens participantes da pesquisa mostram que eles se posicionam criticamente quanto à presença e a importância da Educação Física na escola. Percebem que se é uma disciplina que está na escola então ela deve ter algo a ensinar, mas não está ensinando.

No entanto, mesmo cultivando o olhar crítico ao defender o componente curricular como importante sua presença na escola, não reconhecem qual é a particularidade da Educação Física, o que a difere das demais disciplinas para a formação do ser humano e a limitam somente ao universo esportivo.

\section{CONSIDERAÇÕES}

As respostas adquiridas na entrevista com os jovens alcançam o objetivo geral estabelecido nessa pesquisa. Compreender a Representação 
Social da Educação Física escolar na perspectiva dos jovens no Ensino Médio. A partir do contexto histórico e social da Educação Física podemos perceber que ainda é forte a representação em prol da predominância dos esportes nas aulas, com a presença do alto rendimento, e as aulas recreacionistas em que os alunos decidem o que vão fazer.

Ao longo dos anos, a Educação Física consolidou uma imagem vinculada ao universo esportivo. Teve seu campo de atuação limitado aos esportes, apresentando o esporte na escola, que visa exclusivamente a ampliação das habilidades motoras daqueles alunos que já apresentam facilidade no desenvolvimento motor, excluindo os alunos com menor aptidão física destinada ao alto nível. Ao contrário, não valoriza o esporte da escola que busca o trato pedagógico com base em conteúdos do componente curricular capaz de ampliar a cultura corporal dos alunos.

Por outro lado, é possível notar na fala dos jovens críticas em relação à atuação da Educação Física na escola, que não está ensinando "o quê" e "como" deveria fazer. Falam sobre a obrigatoriedade de se ter a disciplina só para passar de ano e não aprender saberes diferentes.

Os jovens entrevistados veem a Educação Física com olhares críticos. Sabem que ela tem algo para ensinar, sabem que é importante seus saberes, mas que não está cumprindo com seus objetivos ou, pelo menos, cumpre parcialmente.

Apesar de críticos, ainda não enxergam a Educação Física como uma disciplina capaz de ampliar a cultura corporal em prol da formação e emancipação integral do ser humano. Ser humano esse com possibilidade de transformação da realidade, crítico, criativo, ético, social e cultural, uma vez que os fins da Educação Física se estendem aos fins da educação formal para a formação de uma sociedade mais avançada. (GONÇALVES, 1994). 


\section{REFERENCIAS}

ABRAMO, H. W. Considerações sobre a tematização social da juventude no Brasil. Departamento de Sociologia. Universidade de São Paulo. Revista Brasileira de Educação. 1997. Disponível em: http://proex.pucminas.br/sociedadeinclusiva/Blog_Direito_de_se_Diferente/Considera\%C3\%A7\%C3\%B5es $\% 20$ sobre $\% 20$ a\%20Tematiza\%C3\%A7\%C3\%A3o\%20Social\%20da\%20Juventude\%20no\%20 Brasil.pdf. Acesso: 24 jan. 2018.

BARBOSA, C. L. A. Educação Física Escolar: as representações sociais. Rio de Janeiro: Sharpe, 2001.

BETTI, M. Educação física e sociedade. São Paulo, Movimento, 1991.

BOURDIEU, P. Algumas Propriedades dos Campos. In. BOURDIEU, P.: Questões de sociologia. Editora Marco Zero Limitada. Rio de Janeiro, 1983.

BOURDIEU, P. Compreender. In. BOURDIEU, P: A miséria do mundo. Petrópolis, RJ: Vozes, 1997.

BOURDIEU, P. O poder simbólico. Tradução Fernando Tomaz (português de Portugal. $3^{\text {a }}$ ed. Rio de Janeiro; Bertrand Brasil, 2000.

CAVALCANTE, C. V. Jovens e estratégias educativas nos espaços urbanos e virtual. Revista Educativa, Goiânia, v. 14, n. 1, p. 135- 153 jan. /jun. 2011.

COLETIVO DE AUTORES. Metodologia do ensino da educação física. São Paulo: Cortez, 1992.

DARIDO, S.C. Educação Física na Escola: questões e reflexões. Rio de Janeiro: Guanabara Koogan, 2003.

DAOLIO, J. Educação Física e o conceito de cultura. $3^{a}$ Ed. Campinas, SP: Autores Associados, 2010.

DARIDO, S. C.; RANGEL, I. C. A. Educação Física na Escola: Implicações para a prática pedagógica. $2^{\mathrm{a}}$ Ed. Rio de Janeiro: Guanabara Koogan, 2014.

DAYRELL, J. O jovem como sujeito social. Universidade Federal de Minas Gerais. Faculdade de Educação. $n^{\circ} 24,2003$. Disponível em: http://www.scielo.br/ pdf/rbedu/n24/n24a04.pdf. Acesso em: 25 jul. 2016. 
FREIRE, J. B. Educação de corpo inteiro: teoria e prática da educação física. São Paulo, Scipione, 1989.

GONÇALVES, M. A. S. Sentir, pensar, agir: corporeidade e educação. Campinas, SP: Papirus, 1994.

GUIMARÃES, M. T. C. Juventude, educação e campo simbólico. Revista Brasileira de Estudos de População, v. 19, n.2, jul./dez. 2002. Disponível em: http:// www.abep.nepo.unicamp.br/docs/rev_inf/vol19_n2_2002/vol19_n2_2002_17notadepesquisa_p295a298.pdf. Acesso em: 26 jul. 2016.

KUNZ, E. Educação física: ensino \& mudanças. ljuí, Editora Unijuí, 1991.

LUDKE, M.; ANDRÉ, M. E. D. A. Métodos de coleta de dados: observação, entrevistas e análise documental. In: LUDKE, M.; ANDRÉ, M. E. D. A. Pesquisa em educação: abordagens qualitativas. São Paulo: EPU, 1986.

MOSCOVICI, S. Representações sociais: investigações em psicologia social. Petrópolis, RJ: Vozes, 2003.

MOSCOVICI, S. A psicanálise, sua imagem e seu público. Tradução de Sonia Fuhrmann. Petrópolis: Vozes, 2012.

NOGUEIRA, M. A.; CATANI, A. (org.). Escritos da Educação. 16ª ed. Petrópolis, RJ: Vozes, 2015.

RIBEIRO, I. Formação em educação física no Brasil: novas orientações legais, outras identidades profissionais? Dissertação Programa de Pós-graduação Stricto Sensu em educação. Pontifícia Universidade Católica de Goiás. Goiânia- GO, 2016. Disponível em: http://tede2.pucgoias.edu.br:8080/handle/ tede/3461. Acesso 25 jun. 2017.

SPADONI, L. Psicologia realmente aplicada ao direito. Cáp. VII e VIII. $2^{a}$ Ed.São Paulo: LTr, 2016.

SOARES, C. L. Educação física: raízes europeias e Brasil. $5^{a}$ ed. Campinas, SP: Autores Associados, 2012. 


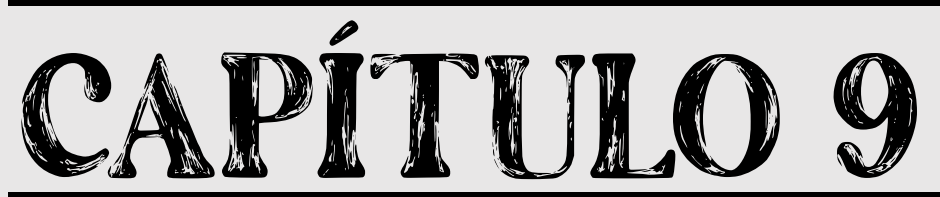

\section{OLHARES DE JOVENS EGRESSOS DO ENSINO MÉDIO: REFLEXÕES SOBRE OS ENLACES NA ESCOLA}

Bianca Isabel Pederiva Suzana Feldens Schwertner 


\section{INTRODUÇÃO}

O que significam cinco anos na vida de um egresso da Escola Básica? Como são construídas as trajetórias dos jovens, após a saída do Ensino Médio? O que diriam os mesmos ao serem questionados acerca dos efeitos do espaço escolar em suas vidas? Essas são algumas das inquietações provocadas pela pesquisa "A escola, cinco anos depois: olhares de egressos" (Univates). Vinculada aos Grupos de Pesquisa Juventudes, Imagem e Educação (JImE/CNPq/ Univates) e Currículo, Espaço, Movimento (CEM/CNPq/Univates), a investigação encontra-se em andamento, sendo o objetivo desta escrita apresentar alguns de seus resultados que, apesar de ainda parciais, mostram-se significativos.

Para discuti-los, optamos por apresentar a escrita indicando a investigação que vem sendo realizada, suas origens, organização e desenvolvimento até o presente momento, incluindo alterações necessárias diante da Pandemia da COVID-19, a partir de março de 2020, que modificou a trajetória metodológica. Em seguida, elencamos três seções de análise dos resultados, apresentando fragmentos das entrevistas realizadas com os jovens egressos e indicando reflexões sobre os enlaces entre juventudes e escola. Já a última seção destina-se às considerações finais, em que apontamos as contribuições da investigação, indicando elementos para pensar sobre tais resultados em tempos de pandemia: como pensar sobre os enlaces proporcionados pela escola para jovens estudantes em tempos de pandemia?

\section{OLHARES DE EGRESSOS: A INVESTIGAÇÃO}

De metodologia qualitativa, a proposta da pesquisa surge de reverberações de um projeto anterior, intitulado "A escola e as novas configurações da escola na contemporaneidade: a voz de estudantes concluintes do Ensino Médio e Fundamental" (MCTI/CNPq/Universal 14/2014), também produzido pelos Grupos de Pesquisa mencionados, entre 2015 e 2017. Naquele momento, procurou-se compreender as percepções de jovens acerca das funções da escola na contem- 
poraneidade, tendo como participantes estudantes concluintes do nono ano do Ensino Fundamental e terceiro ano do Ensino Médio. Foram realizados grupos focais, concentrados em duas escolas parceiras, uma pública e outra privada, totalizando mais de 50 encontros, com a presença de 117 estudantes.

Cada turma investigada englobava quatro encontros, nos quais os estudantes tiveram a oportunidade de conversar sobre a temática, sendo que nos dois primeiros visava-se pensar acerca dos seguintes questionamentos: quais as funções da escola hoje? Como a escola organiza a divisão dos saberes e/ ou conhecimentos? Em um terceiro momento, os estudantes destinavam-se à produção de uma fotografia legendada que representasse uma síntese dos debates anteriores, de acordo com a própria percepção dos mesmos. Já no último encontro, aconteciam os compartilhamentos das imagens capturadas - e criadas - pelos estudantes aos demais participantes do grupo (SILVA; SCHWERTNER, ZANELATTO, 2019).

A partir dessa pesquisa, tornou-se evidente o desejo dos jovens de que pudessem ter suas percepções sobre o espaço escolar escutadas. Esse resultado é retratado por Schwertner e Conrad (2021), em trabalho que destacam a necessidade da escola promover mais espaços de diálogo, de debate, de trocas entre estudantes e entre todos aqueles que se encontram como habitantes da instituição. Outras contribuições também podem ser conferidas em Schwertner e Conrad (2016); Schwertner e Munhoz (2018) e Schwertner (2019).

Cinco anos após a realização daquela pesquisa, pergunta-se: quais são os olhares de egressos para a Escola Básica, após a conclusão do Ensino Médio? Os principais objetivos da presente investigação buscam analisar o olhar de egressos da Escola Básica acerca dos efeitos da instituição em suas vidas, identificando suas trajetórias e problematizando as diferenças e as singularidades das mesmas. Autores como Juarez Dayrell (2003, 2007); Silva e Oliveira (2016); Leão e Carmo (2014) e Silva (2016) constituem o referencial teórico desta investigação, em especial ao articular a temática da juventude com o universo escolar. Conforme Leão e Carmo (2014), a trajetória escolar tem uma função fundamen- 
tal na vida dos jovens após a escola e diversas pesquisas têm mostrado que eles apresentam dificuldades para estabelecer conexão entre os componentes curriculares da escola de Ensino Médio e suas vidas. Para os autores, o maior desafio da instituição escolar, hoje, seria articular um vínculo entre o ser jovem e o ser estudante: o que compreendem hoje sobre as funções da escola em suas vidas? O que dizem sobre os elementos que compõem a escola, seus efeitos e desdobramentos na produção de subjetividades jovens?

A metodologia, de viés qualitativo, é organizada por meio de entrevistas semiestruturadas com egressos do terceiro ano do Ensino Médio que participaram do projeto anterior: um convite, enviado via redes sociais ${ }^{1}$, colocou as pesquisadoras em contato novamente com os jovens, relembrando o projeto anterior e propondo um novo encontro. Até o momento, foram realizadas quatorze entrevistas com aqueles que aceitaram participar da nova investigação, sendo os mesmos estudantes concluintes dos anos de 2015 (seis egressos) e 2016 (oito egressos). Ressalta-se que todos assinaram o Termo de Consentimento Livre e Esclarecido (TCLE) e que a pesquisa teve aprovação do Comitê de Ética em Pesquisa da Universidade do Vale do Taquari - Univates (CAAE: 30630620.7.0000.5310).

Em virtude da Pandemia da COVID-19², a organização da entrevista precisou ser adaptada para os meios virtuais de comunicação, com a possibilidade de encontros via Google Meet $^{3}$. Sendo individual e com a duração média de 30 minutos, os egressos foram convidados a compartilhar sobre sua vida na escola e para além da escola, contando sobre sua trajetória após a saída do Ensino Médio. Foram elencadas sete perguntas, além de um questionamento acompanhado de fotoelicitação, com a fotografia produzida por cada um dos estudantes, à época da pesquisa. Tal técnica (BANKS, 2009) consistiu justamente na apresentação da fotografia aos participantes, via apresentação online, caracterizando um

\footnotetext{
1 As pesquisadoras realizaram uma busca ativa dos participantes da pesquisa anterior, efetuando o novo convite via Instagram e Facebook, redes sociais destinadas ao compartilhamento de informações entre usuários.

2 Conforme o site da Organização Pan-Americana da Saúde (https://www.paho.org/pt), a COVID-19 é uma doença infecciosa causada pelo novo coronavírus (SARS-CoV-2). Foi caracterizada como uma pandemia pela Organização Mundial de Saúde em 11 de março de 2020.

3 Serviço ofertado pela empresa Google para videoconferências.
} 
processo que auxiliou no movimentar do pensamento e na construção de narrativas singulares. A fotoelicitação possibilita o compartilhamento de experiências, construindo com o entrevistado sua participação na investigação e permitindo a discussão de temas contemporâneos (WOODGATE; ZURBA; TENNENT, 2017).

As questões que acompanharam as imagens versaram em torno das lembranças dos egressos acerca da participação na pesquisa anterior, quando ainda eram estudantes, e dos sentimentos despertados pela imagem no momento atual. Também foram instigados a pensar sobre o que diriam para si mesmos, para a escola e para seus professores, se pudessem voltar no tempo, cinco anos atrás. As demais perguntas, realizadas sem a fotografia, concentravam-se em um relato acerca de como descreveriam a vida no tempo escolar e após seu término, enquanto egressos do Ensino Médio. Ao final, eram questionados sobre os efeitos da instituição em suas trajetórias, temática que une as demais provocações e torna-se disparadora desta escrita.

Dos efeitos expostos pelos egressos, destaca-se neste artigo a sociabilidade, percebida nos enlaces constituídos pelos mesmos enquanto habitantes do espaço escolar. Fazendo-se relevante até os dias atuais, cinco anos após o término do Ensino Médio, as ressonâncias dessa temática foram percebidas em doze das quatorze entrevistas realizadas na pesquisa. A identificação dos excertos dos participantes, neste texto, é representada com a letra "E", acrescida do número da ordem cronológica de realização das entrevistas, bem como do ano de participação do egresso. Por exemplo: (E1, 2020), (E2, 2020), (E3, 2020), e assim sucessivamente.

Tendo como base para o tratamento de dados a Análise Textual Discursiva (MORAES; GALIAZZI, 2011), as transcrições das entrevistas foram examinadas em detalhes. Primeiro, operou-se em uma fase de fragmentação dos textos, visualizando possíveis unidades de significado. Após, ocorreu uma articulação das mesmas, em que se estabeleceu a criação de novas compreensões, expressas em categorias. Este artigo, por fim, pode ser entendido como um metatexto pelo viés metodológico, representando uma tentativa de explicitar os sentidos provenientes do processo de análise. 


\section{A FORÇA DA AMIZADE QUE SE ENLAÇA NA ESCOLA}

"[...] na escola tu faz laços que duram a vida toda" (E5, 2020), afirma-nos um dos egressos. E assim, logo iniciamos a discussão com a provocação de que um dos efeitos do espaço escolar, "[...] é criar laços" (E5, 2020), conforme o mesmo complementa, com convicção. A escola é percebida como um lugar de união, de ligação entre jovens. Como um local que propicia a construção de amizades, de enlaces entre pessoas. Enlaces que, de acordo com o egresso, perduram nas trajetórias daqueles que nela se conheceram.

Em pesquisa realizada com 122 estudantes de $7^{\mathrm{a}}$ e $8^{\mathrm{a}}$ séries de uma escola pública da região sul do país, Schwertner (2012) já evidenciava essa questão: "[...] a escola é, definitivamente, o reduto por excelência, escolhido por eles, para encontrar seus amigos; é na escola que, de fato, está a maioria dos amigos de cada um dos jovens pesquisados" (SCHWERTNER, 2012, p. 182). Tal entendimento provém do fato de que $90 \%$ dos jovens participantes daquela investigação indicaram, por meio de seleção de imagens, que seus amigos são aqueles com quem convivem no espaço escolar.

Percebe-se que afirmativas como essas, apresentadas por Schwertner (2012), recebem certa continuidade na presente pesquisa, ainda que realizada com egressos do Ensino Médio - os quais encontram-se, atualmente, na faixa dos 21 (8 participantes), 22 (5 participantes) e 23 (1 participante) anos. Relatadas com um sentimento de nostalgia, as amizades construídas no Ensino Médio aparecem na fala dos jovens como laços que são desenvolvidos no cotidiano da escola, não somente entre estudantes, como também com professores:

As amizades. Por mais que tenha uma grande maioria, dá pra dizer assim, 95\% dos amigos que eu tinha na escola, não fazem mais parte do meu círculo de amigos hoje. Mas, mesmo assim, a gente tem aquele carinho quando encontra a pessoa (E7, 2021).

As amizades que eu fiz ali, que eu construí, que eu levo até hoje, cada pessoa que passou, enfim, não só colegas, mas amigos. Os profs. também, que eu tenho contato até hoje também, eu gosto muito deles. Então eu descreveria como um dos melhores momentos que eu passei, mais importantes para formar quem eu sou (E11, 2021).

Mas eu lembro que sim, foi... é uma experiência que marca pra sempre. As amizades, têm amizades que seguem até hoje. Então, a construção 
de uma pessoa hoje em dia, dentro de uma escola, é algo fundamental para a vida de qualquer pessoa (E12, 2021).

Ter conhecido amigos que eu ainda, mesmo não tendo mais muito contato, eu converso no WhatsApp sempre que possível. De vez em quando rola um chimarrão no domingo, não agora no coronavírus, então faz uns dois anos já que não vejo os meus amigos do terceiro ano, minhas colegas. Mas ficou amizades, então (E14, 2021).

A partir de fragmentos das entrevistas, percebemos como a presença da sociabilidade na instituição escolar é uma pauta que demanda atenção. De acordo com Dayrell (2007), quando falamos em sociabilidade estamos nos referindo justamente às relações que acontecem na fluência do cotidiano, tanto nos espaços sociais constituídos fora da instituição, como também naqueles criados no interior da mesma. Podemos visualizar tal compreensão a partir da escolha de E10 (2021) que, presente nos momentos de discussão, mas não participando da produção de imagens, seleciona uma fotografia ${ }^{4}$ criada pelos colegas naquela época, para realizar o processo de fotoelicitação:

Imagem 1 - "Todos abraçados, momentos que passamos juntos vão ficar para sempre"

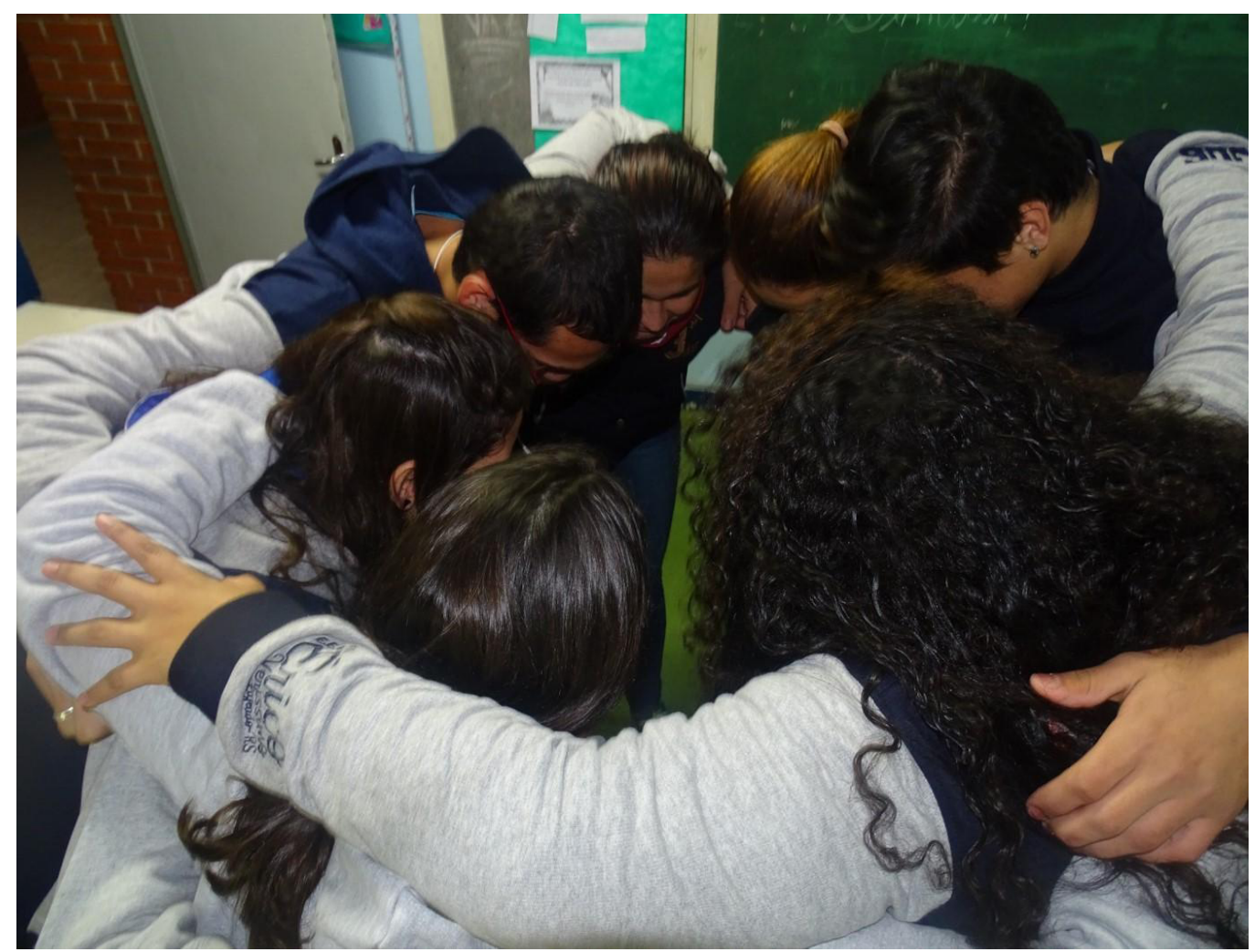

Fonte: Arquivo de pesquisa, 2016.

$4 \quad$ Ressalta-se que a fotografia deveria apresentar uma legenda, sendo aqui exposta no título das imagens apresentadas. 
Na construção da sociabilidade na escola, Dayrell (2007) considera que acontece uma formação de "[...] expressão da condição juvenil nos determinismos estruturais" (DAYRELL, 2007, p. 1111). Ou seja, podemos compreendê-la como algo que movimenta o espaço, desestabilizando as lógicas institucionalizadas que, por vezes, atuam em seu endurecimento. Ampliando a perspectiva, talvez a força dessa amizade, que se enlaça na escola, é algo que pode favorecer a criação daquilo que Biesta (2020) sugere como "estado de diálogo", pensando-o como uma maneira de existirmos enquanto sujeitos. Segundo o autor, encontrar-se neste estado significa:

[...] estar exposto ao quê e quem é o outro, ser abordado pelo quê e quem é o outro, ser ensinado pelo quê e quem é outro, e ponderar o que isso significa para a nossa própria existência e para os desejos que temos em relação à nossa existência (BIESTA, 2020, p. 26).

Tal concepção complementa-se com outra preposição de Dayrell (2007), no momento em que pensa a turma de amigos como uma referência para que os jovens possam criar formas de se afirmar diante do mundo adulto. Assim, a escola aparece como um espaço que permite esses acontecimentos, pois justamente oportuniza o encontro com o outro - com aquele que me identifico, com aquele que me diferencio, com aquele que posso dialogar.

Nesse sentido, retomando Schwertner (2012), percebemos que as relações de amizade tanto propiciam alívio ao desamparo, quanto também impulsionam o jovem a "[...] confrontar-se com a alteridade, com o outro em sua diferença e estranheza" (SCHWERTNER, 2012, p. 166). Esse foi um próximo aspecto levantado pelos jovens, o qual interliga-se com as nossas discussões e é abordado com maior destaque na próxima seção.

\section{O ENCONTRO COM O OUTRO E A FORMAÇÃO HUMANA}

A juventude é uma palavra que se pensa no plural, segundo nos oportuniza compreender Dayrell (2003): passamos então a nominar juventudes. Apresenta-se no plural, pois não há a possibilidade de a incluirmos em uma categoria única. Longe disso, as juventudes são permeadas por amplos proces- 
sos de constituição de sujeitos, que dizem de contextos históricos, sociais, econômicos e culturais em que os jovens estão inseridos. Portanto, há "[...] diferentes modos de vivenciar a juventude" (DAYRELL; CARRANO, 2014, p. 112), os quais mobilizam-se e transformam-se dinamicamente, conforme as mudanças que se atualizam no cotidiano de suas relações com o mundo. Corroborando com esse entendimento, Nunes, Pádua e Araújo (2021) destacam:

A complexa condição social e cultural dos jovens possui uma dinâmica própria, que sofre mutações com o tempo e o espaço que ocupam. Daí a impossibilidade de universalizar a condição juvenil, desconhecendo a sua historicidade e a sua trajetória (NUNES; PÁDUA; ARAÚJO, 2021, p. 642).

No espaço da escola, como viemos abordando nesta escrita, não é diferente. Grande parte dos egressos entrevistados retrata que um dos efeitos da instituição em suas trajetórias de vida pode ser apontado pelo fato de aprender a conviver com as diferenças - com aquilo que diz do outro e que, por conseguinte, ao mesmo tempo, também diz de nós -, daquilo que talvez ainda não conhecemos. Também na escola há modos distintos de vivenciar a juventude, os quais permitem criar novas maneiras de experienciar o espaço, de compartilhá-lo com outros estudantes, professores, gestores, funcionários e demais pessoas que nele coabitam; aprender a conviver, enfim. Conforme os egressos:

E é isso que me deixa o colégio. É o acolhimento, é o estar junto das pessoas. É o conhecer. Acho que isso é o que mais, é o mais relevante. Porque é o contato, é tu saber lidar, é tu saber conversar com as pessoas e eu acho que com certeza, foi isso que o colégio me deixou (E1, 2020).

Eu acho também no sentido de aprender a conviver com diferentes pessoas né, que às vezes é um pouco difícil né e às vezes tu acaba encontrando amigos que tu leva pra vida inteira né. Então tem esses dois lados, $\operatorname{assim}(E 2,2020)$.

E a escola não me deu uma base só de matéria, português, inglês, matemática, me deu uma base muito de como lidar com o outro, como ser humano, como tudo. Tanto na parte positiva, quanto na parte negativa [...]. Tanto aprender a ser uma pessoa que sabe lidar com os outros, como também a defender os seus direitos quando tu acha que não é bem assim que funciona o negócio. Então a escola me fez crescer muito como 
um ser humano e eu vejo que tudo que veio depois, a faculdade, tudo, foi só uma continuação (E3, 2020).

Todos os ensinamentos, tanto de conteúdo, de matéria, como a parte de eles ensinarem como o aluno deve se portar, futuramente assim, tudo isso eu trago comigo até hoje $(E 9,2021)$.

"Me ensinou a ter respeito pelas pessoas. Reconhecer quando uma pessoa precisa de ajuda e tu quer ajudar" (E10, 2021), é como um egresso também aponta. Assim, complementa-se a perspectiva de que um dos efeitos do espaço escolar na trajetória de vida dos jovens entrevistados diz respeito aos ensinamentos oportunizados pela experiência de "[...] estar junto das pessoas" (E1, 2020). E vale destacar que tal modo de acolher e ser acolhido acontece nesse espaço extrafamiliar, em que os jovens vão se experimentando para além do espaço privado do lar, em que o contato com o espaço público escolar (ainda que limitado pelo ambiente da escola) proporciona encontros e descobertas. A escola como uma cápsula temporal (LARROSA, 2018), como um lugar que não vai ao encontro apenas daquilo que é da família (e assim, mais conhecido e do terreno do privado) (MASSCHELEIN; SIMONS, 2014) e que faz "crescer muito como ser humano", como ressalta E3 (2020).

Uma experiência de construção de diálogos, encontros e trocas com outros jovens, com outras pessoas. Uma possibilidade de contato com novas perspectivas de vida e de mundo, que apresentam múltiplas maneiras de vivenciar as juventudes em seu caráter dinâmico e plural (DAYRELL, 2003). Tal é o sentido apresentado por E8 (2020), quando versa sobre a escola como um espaço de "[...] experiências de vida", em que aprendeu muitas das coisas que atualmente perpassam sua trajetória. Em sua imagem, produzida em 2016, podemos visualizar as mãos de seus colegas, criando um compartilhamento de experiências, bem como de expectativas em relação às possibilidades do futuro. A egressa segue analisando sua fotografia: "Acho que eu quis projetar ali um... tipo um mundo de coisas que vem depois do terceiro ano, né? Tipo, tudo que tu vai ter que passar, tudo que tu vai ter que viver e escolher, né? E que isso, às vezes, é até um pouco assustador [...]" (E8, 2020). 
Imagem 2 - "Escolhas"

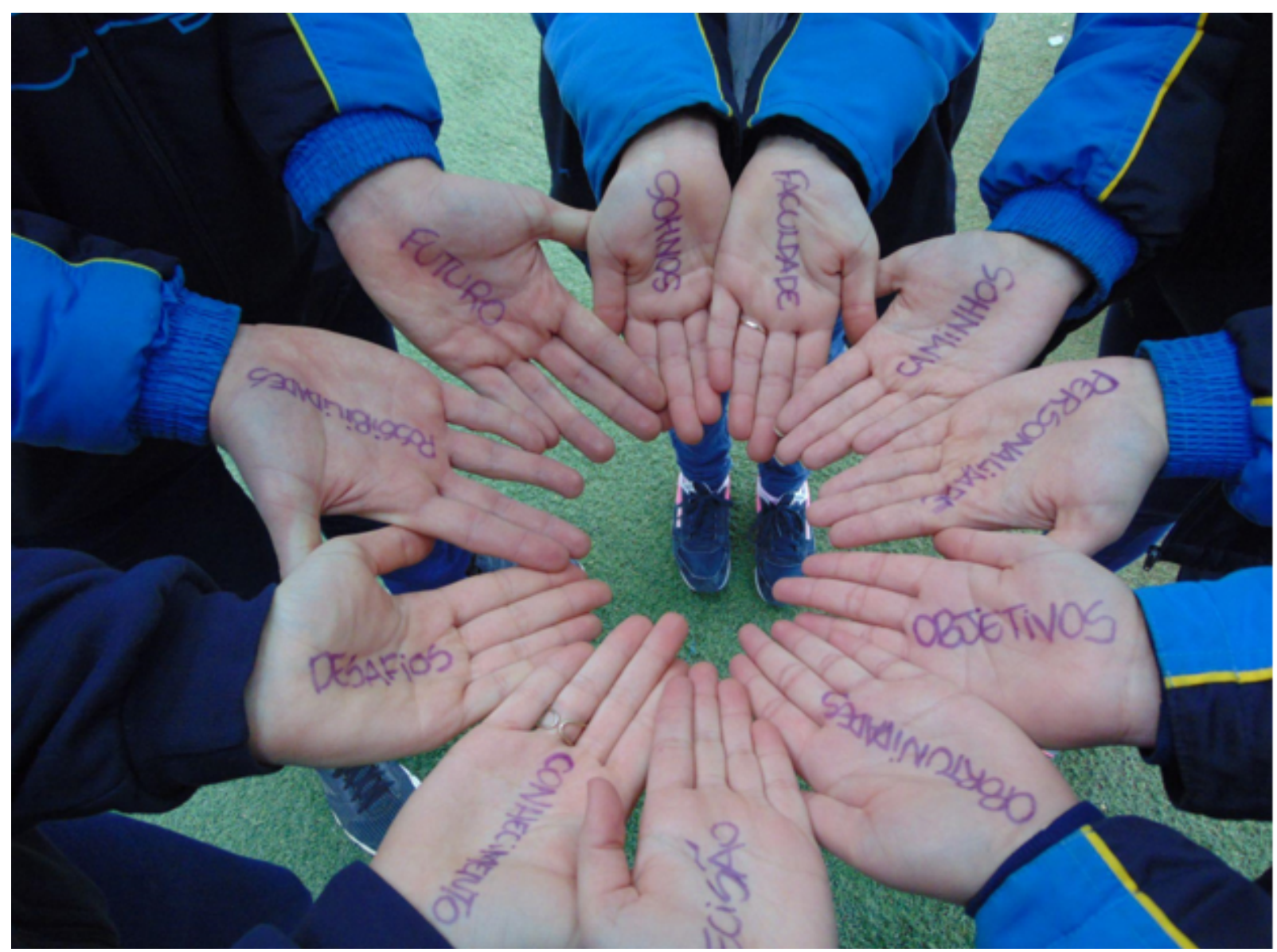

Fonte: Arquivo de pesquisa, 2016.

Se, a partir das contribuições de Arroyo (2014, p. 161), compreendermos que um dos mais relevantes direitos do ser humano é de ele próprio conhecer-se, "[...] se saber no mundo, na história, nas relações sociais, econômicas, políticas e culturais", percebemos a escola como um espaço propício para tanto. Como destaca um dos egressos nos fragmentos dispostos anteriormente, seu crescimento enquanto ser humano foi proveniente do espaço escolar, ao passo que aponta as vivências dos últimos cinco anos como uma continuação de tal constituição. Ainda, comenta que a instituição contribuiu para "[...] ser uma pessoa que sabe lidar com os outros, como também a defender os seus direitos [...]" (E3, 2020).

Os encontros também podem ser oportunizados por atividades extraclasses, como a participação em uma orquestra instrumental, por exemplo. Também ali há a possibilidade do desenvolvimento de inúmeras habilidades sociais, que segundo os egressos, contribuíram para a sua formação humana: 
E com certeza, toda certeza, a orquestra foi algo que me fez ser muito mais comunicativa, embora eu não seja tanto. Mas, com certeza foi o que me ajudou muito na questão de conversar, de falar com pessoas diferentes. Porque toda vez que a gente saia pra algum encontro de orquestras, a gente tinha que ficar na casa de alguém, de alguma família. Então eram pessoas totalmente desconhecidas, que eu não conhecia e que eu nunca tinha visto na vida e isso me fez conseguir me abrir. Me abrir não, mas saber conversar, conhecer as pessoas $(E 1,2020)$.

Parece ser do encontro com o outro, enquanto experiência de formação humana, que os egressos nos falam. Sendo assim, é na disposição de um espaço de confronto com a alteridade (SCHWERTNER, 2012) - o qual se enlaça nas amizades e se desenvolve na diferença - que encontramos uma das potências da escola, ainda presente na trajetória de vida dos jovens entrevistados, após cinco anos de saída da instituição.

\section{A CONSTRUÇÃO DE ESPAÇOS DE ENLACE}

Então, assim, o que me marcou, principalmente, foi no momento em que a bolsista nos deu câmeras fotográficas, a todos nós, e que a gente poderia registrar algum momento da escola que nos marcasse. E eu fui até a biblioteca e tirei foto da biblioteca, que era um lugar em que eu passava muito tempo na escola, inclusive com a Dona I., não sei se ela trabalha lá ainda... Mas que passava lá com os meus amigos. Então era um lugar... Inclusive alguns lanches escondidos a gente comia lá e aproveitava para conversar sobre filmes, sobre jogos, sobre livros, enfim, sobre tudo que nós conversávamos. E no noturno, nessa época, eu trabalhava o dia todo e estudava à noite, eu tive essa oportunidade $(E 4,2020)$.

Como são construídos momentos de convivência na escola? Como são oportunizados encontros entre os jovens? Em que sentido a instituição escolar, permeada por seus próprios espaços, pode contribuir para a criação de enlaces entre jovens?

Percebe-se que tal fragmento, resultante do momento de fotoelicitação ${ }^{5}$, nos possibilita pensar em tais questionamentos, compreendendo a importância da biblioteca para a vida escolar do egresso entrevistado. A biblioteca enquanto espaço de estudo, de encontro e de pequenas transgressões potentes, que

$5 \quad \mathrm{Na}$ imagem 2 podemos visualizar a fotografia produzida por E4 (2020); foi a partir de tal imagem que o entrevistado iniciou a discussão sobre a biblioteca. 
impulsionavam diálogos sobre arte, cultura e vida. "[...] era um lugar..." (E4, 2020), nos relata o egresso, emocionado com tal lembrança e nos provocando a imaginar as cenas, com o auxílio da imagem produzida pelo mesmo em 2015.

Imagem 2 - "Os livros nos levam aos mais diversos lugares"

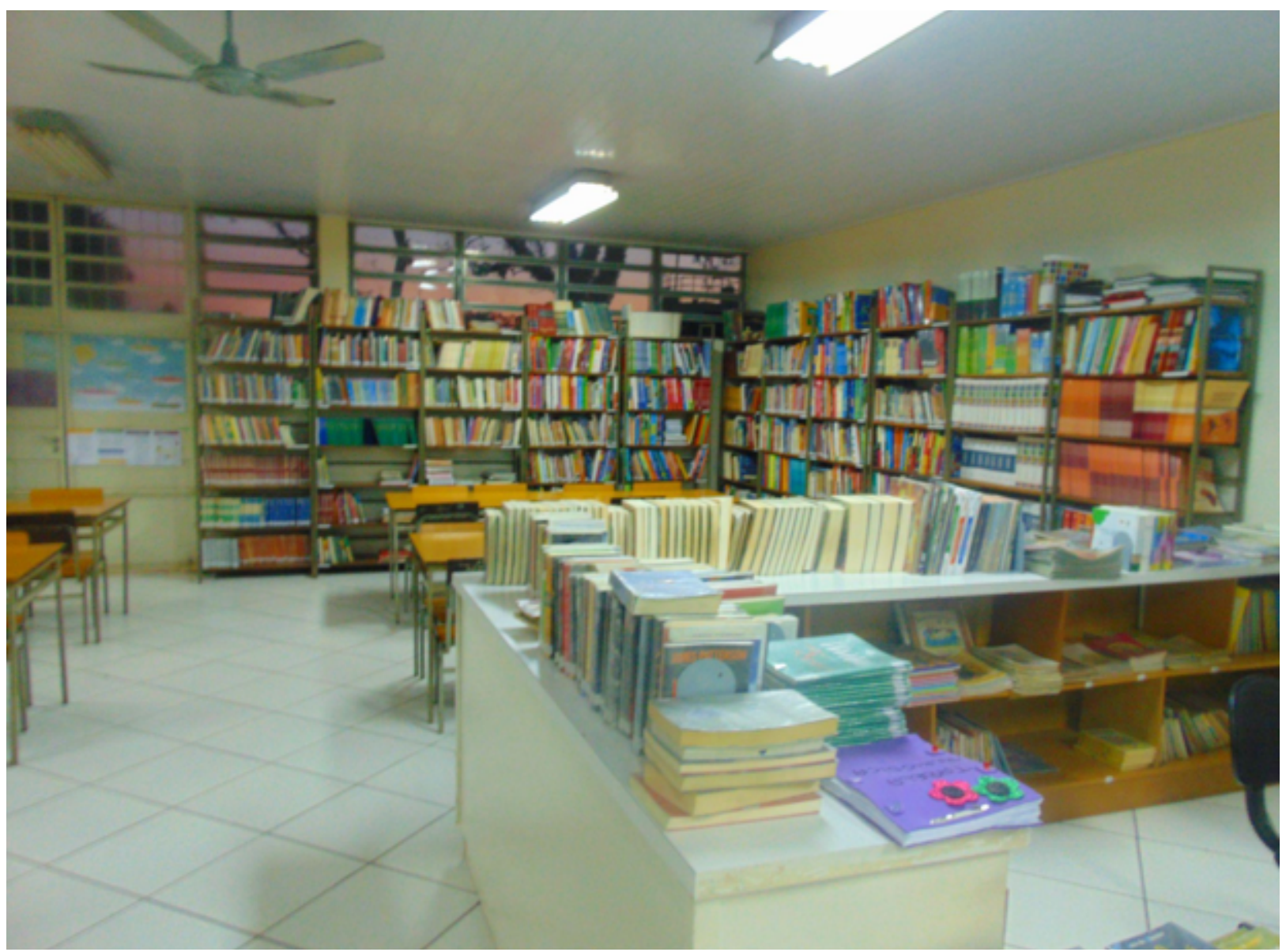

Fonte: Arquivo de pesquisa, 2015.

$\mathrm{Na}$ escola há, por vezes, um estabelecimento de locais específicos para diferentes funções - sala de aula: estudar; biblioteca: ler (em silêncio); pátio: descansar -, o que faz com que seus espaços possam se tornar um tanto fragmentados e institucionalizados. Para Leão e Carmo (2014), como efeito de tais separações, estão as poucas possibilidades para que as juventudes e suas multiplicidades sejam reconhecidas e incorporadas na instituição. Em consequência, isso faz com que exista uma carência de tempo para que os jovens possam conversar sobre temas que lhes interessam e que também compõem suas vidas de estudantes. Concomitante, percebe-se que atitudes como as pequenas transgressões realizadas na biblioteca demonstram o quanto os estudantes procuram 
apropriar-se dos espaços da escola, transformando-os em espaços sociais, de trocas. É também o que nos possibilita pensar Dayrell (2007), quando relata sobre essa incorporação da vida juvenil à escolar:

[...] novos scripts sociais estão sendo criados e executados pelos jovens alunos, em meio ao conjunto das interações que ocorrem na escola. Em meio à aparente desordem, eles podem estar anunciando uma nova ordem que a instituição escolar ainda insiste em negar (DAYRELL, 2007, p. 1121).

Talvez seja nesse conjunto de interações - pela construção de espaços de enlace - que a escola também pode aparecer como uma "comunidade única", conforme versam Masschelein e Simons (2015). A escola como uma comunidade de pessoas distintas que, ao confrontarem-se com o que é fornecido, experimentam "[...] o que significa compartilhar alguma coisa e ativar sua capacidade de renovar o mundo" (MASSCHELEIN; SIMONS, 2015, p. 85).

Dessa forma, propõe-se pensar a escola tanto como uma "cápsula temporal" (LARROSA, 2018), como exposto na seção anterior, quanto como um lugar propício para aquilo que é público, para experimentação de bens comuns que estão "[...] abertos e disponíveis para novos usos e novos significados no estudo e na prática" (MASSCHELEIN; SIMONS, 2015, p. 85). Na perspectiva dos autores, o elemento democrático e político da educação encontra-se em tal abertura: que os estudantes possam experienciar um mundo outro, um mundo que é compartilhado.

Além do espaço da biblioteca, outros lugares e momentos foram apresentados pelos egressos, como as gincanas escolares. Segundo E11 (2021), por mais que as mesmas possam aparentar ser algo "[...] infantil, uma coisa que é né, sei lá, não real, tu aprende muito também. Trabalhar em equipe, tu aprende tipo, liderança, tu aprende a compartilhar com os outros. Enfim, relacionamentos". Novamente, percebemos o relevante significado dos compartilhamentos oportunizados pelos espaços e tempos da escola, com os mais diferentes personagens que compõem esse universo. 


\section{CONCLUSÃO}

O presente capítulo teve como objetivo apresentar resultados parciais de uma investigação em curso, que busca analisar o olhar de jovens egressos da Educação Básica acerca dos efeitos da escola em sua trajetória de vida. Chama atenção, nessa análise, a força das amizades que se iniciam na escola e seguem com os jovens egressos em seu universo além do institucional; a ênfase que eles imprimem nos aspectos da formação humana pautados pela escola e a elaboração de lugares de sociabilidade que tal espaço possibilita, no encontro entre estudantes.

Ressaltamos que tais resultados fortalecem uma das funções da escola, a socialização, que marca as trocas entre estudantes, professores e demais funcionários da escola. E então nos perguntamos: como pensar sobre o enlace a partir da pandemia da COVID-19, que fechou escolas em março de 2020 no Brasil e impossibilitou os encontros em seu interior? Como seria escutar egressos acerca das funções de socialização da escola a partir da pandemia? Quais as repercussões dessa impossibilidade de elaborar espaços de trocas na instituição escolar, na biblioteca, nas atividades extraclasses, nos intervalos? São perguntas que permanecem em aberto e que nos convocam a seguir pesquisando.

\section{REFERENCIAS}

ARROYO, Miguel. Os jovens, seu direito a se saber e o currículo. In: DAYRELL, Juarez (org.). Juventude e Ensino Médio. Belo Horizonte: UFMG, 2014, p. 157203. Disponível em: https://educacaointegral.org.br/wp-content/uploads/2015/01/ livro-completo_juventude-e-ensino-medio_2014.pdf. Acesso em: 09 set. 2021.

BANKS, Marcus. Dados visuais para pesquisa qualitativa. Tradução de José Fonseca. Porto Alegre: Artmed, 2009.

BIESTA, Gert. A (re)descoberta do ensino. São Carlos: Pedro \& João Editores, 2020. 
DAYRELL, Juarez. O jovem como sujeito social. Revista Brasileira de Educação. Rio de Janeiro, n. 24, p. 40-52, 2003. Disponível em: https://www.scielo.

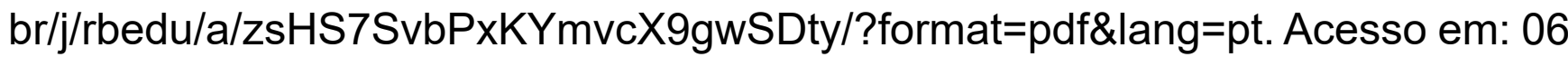
set. 2021

DAYRELL, Juarez. A escola "faz" as juventudes? Reflexões em torno da socialização juvenil. Educ. Soc., Campinas, v. 28, n. 100, p. 1105-1128, 2007. Disponível em: https://www.scielo.br/j/es/a/RTJFy53z5LHTJjFSzq5rCPH/?lang=pt\&format=pdf. Acesso em: 09 set. 2021.

DAYRELL, Juarez; CARRANO, Paulo. Juventude e Ensino Médio: quem é este aluno que chega à escola. In: DAYRELL, Juarez (org.). Juventude e Ensino Médio. Belo Horizonte: UFMG, 2014. p. 101-133. Disponível em: https://educacaointegral.org.br/wp-content/uploads/2015/01/livro-completo_juventude-e-ensino-medio_2014.pdf. Acesso em: 09 set. 2021.

LARROSA, Jorge. Esperando não se sabe o quê: sobre o ofício de professor. Belo Horizonte: Autêntica Editora, 2018.

LEÃO, Geraldo; CARMO, Helena Cristina do. Os jovens e a escola. In: CORREIA, Licinia M; ALVES, Maria Z.; MAIA, Carla L. (orgs.). Cadernos Temáticos: Juventude Brasileira e Ensino Médio - Caderno 3. Belo Horizonte: Editora UFMG, 2014. p. 11-44.

MASSCHELEIN, Jan; SIMONS, Maarten. A pedagogia, a democracia, a escola. Belo Horizonte: Autêntica Editora, 2014.

MASSCHELEIN, Jan; SIMONS, Maarten. Em defesa da escola - uma questão pública. 2 ed. Belo Horizonte: Autêntica Editora, 2015.

MORAES, Roque; GALIAZZI, Maria do Carmo. Análise textual discursiva. 2. ed. Ijuí: Editora Unijuí, 2011.

NUNES, Cecília M. F.; PÁDUA, Karla Cunha; ARAÚJO, Regina Magna B. de. "Tô aprendendo a sonhar": narrativas de jovens e sua relação com a escola. Revista Brasileira de Pesquisa (Auto)Biográfica, Salvador, vol. 06, $n^{\circ} 18, p$. 635-650, 2021. Disponível em: https://www.revistas.uneb.br/index.php/rbpab/article/view/11883/8578. Acesso em: 13 set. 2021. 
SCHWERTNER, Suzana Feldens. Palavras e imagens sobre amizade jovem na contemporaneidade. Educação \& Realidade. Porto Alegre, v. 37, n. 1, p. 163-185, 2012. Disponível em: https://seer.ufrgs.br/educacaoerealidade/article/ view/13947. Acesso em: 24 ago. 2021.

SCHWERTNER, Suzana Feldens. Fotografias em discurso: as funções da escola em foco. Reflexão e Ação (versão eletrônica), v. 27, p. 133-150, 2019. Disponível em: https://online.unisc.br/seer/index.php/reflex/article/view/10930/pdf. Acesso em: 16 ago. 2021.

SCHWERTNER, Suzana Feldens; CONRAD, Jaqueline. Um click na escola: olhares e discursos de jovens estudantes sobre a instituição escolar contemporânea. Caderno Pedagógico, Lajeado, v. 13, n. 2, p. 28-46, 2016. Disponível em: http://www.univates.br/revistas/index.php/cadped/article/view/1126. Acesso em: 16 ago. 2021.

SCHWERTNER, Suzana Feldens; CONRAD, Jaqueline. Pesquisar entre jovens e imagens: a escola no caminho. Criar Educação, Criciúma, v. 9, n. 1, p. 243-263, 2021. Disponível em: http://periodicos.unesc.net/criaredu/article/view/4141/5732. Acesso em: 16 ago. 2021.

SCHWERTNER, Suzana Feldens; MUNHOZ, Angélica Vier. Fotografias na escola: discursos de jovens estudantes. Ensaios Pedagógicos, Sorocaba, v. 2, n. 03 , p. 37-46, 2018. Disponível em: http://www.ensaiospedagogicos.ufscar.br/index. php/ENP/article/view/107/133. Acesso em: 16 ago. 2021.

SILVA, Clebson Assis da; SCHWERTNER, Suzana Feldens; ZANELATTO, Elisângela Mara. Grupos focais: desafios e possibilidades na pesquisa qualitativa. Debates em Educação, Alagoas, v. 11, n. 24, p. 1-13, 2019. Disponível em: https://www.seer.ufal.br/index.php/debateseducacao/article/view/6852/pdf. Acesso em: 13 ago. 2021.

SILVA, Mônica Ribeiro da; OLIVEIRA, Rosângela Gonçalves de. Juventude e Ensino Médio: sentidos e significados da experiência escolar. Curitiba: UFPR/ Setor de Educação, 2016.

SILVA, Mônica Ribeiro da (org.). O Ensino Médio: suas políticas, suas práticas. Curitiba: UFPR/Setor de Educação, 2016.

WOODGATE, Roberta; ZURBA, Melanie; TENNENT, Pauline. Worth a thousand word? Advantages, challenges and opportunities in working with photovoice as qualitative research method with youth and their families. Forum: qualitative social research, v. 18, n. 1, 2017. Disponível em: http://www.qualitative-research .net/index.php/fqs/article/view/2659/4045. Acesso em: 09 set. 2021. 
dol $10.48209 / 978-65-J U V E N-40-0$

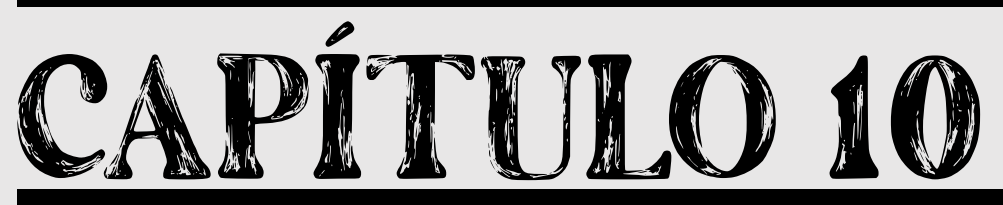

\section{EDUCAÇÃO \\ DO/NO CAMPO \\ E A JUVENTUDE QUE $O$ HABITA}

Gracielle de Souza Silva Joana D'arc Bardella Castro 
"A educação do campo do povo agricultor precisa de uma enxada, de um lápis e de um trator precisa do educador pra trocar conhecimento o maior ensinamento é a vida e o seu valor". (Gilvan Santos, músico popular da reforma agrária, 2006).

\section{INTRODUÇÃO}

O movimento da Educação do/no Campo consiste numa relação entre os movimentos sociais e o Estado. Na atualidade, vem sendo discutido a necessidade de políticas públicas que garantam e promovam aos estudantes (agricultores, camponeses, indígenas, quilombolas e outros) uma educação de qualidade em seu próprio território/região. Conforme Argenton (2020) a escola é vista como um instrumento promovedor de garantias de direitos em seu exercício e possibilita ações de defesa aos estudantes e professores. Para os trabalhadores do campo, ou seja, aqueles que estão inseridos nesse contexto, o espaço escolar não se limita apenas numa função de educação formal, mas num espaço de inclusão social. Este espaço escolar permite o conhecimento/contato com o Estado, com as políticas públicas e, é um lugar de diversos acessos (cultural, musical, comida, mídia e outros) para essa comunidade estudantil.

Ao discutir sobre a Educação do/no Campo, buscamos refletir sobre os seus objetivos, suas perspectivas metodológicas e as pretensões políticas ligadas ao processo de construção prático/teórico desta educação, juntamente com as necessidades e as questões do cotidiano vivido no campo. $\mathrm{E}$ aliado aos dispositivos da Constituição Federal, está deliberada na Lei de Diretrizes e Bases da Educação Nacional (LDB), lei n. ${ }^{\circ}$ 9.394/1996, nos artigos 23, 26 e 28, a particularidade do campo em seus aspectos sociais de forma geral.

No caput do artigo 28 da LDB, está a garantia do direito dos sujeitos/pessoas do campo a um ensino de qualidade, adequado à sua diversidade cultural. Neste aspecto, há uma necessidade de inserir novas técnicas pedagógicas di- 
ferenciadas, ou seja, adaptações metodológicas e curriculares que contemplem essas especificidades.

Assim, há determinação nas diretrizes que estabelecem também as obrigações/obrigatoriedade do poder público em oferecer a educação infantil (séries iniciais) na própria comunidade rural. Segundo o Grupo de Trabalho Interinstitucional (GTI) (2014) ressalta que a oferta da educação infantil para as crianças/ bebês que vivem em áreas rurais, é garantida com amparo na legislação, ficando sobre os cuidados/responsabilidade dos municípios, com auxílio da União, do Distrito Federal e dos Estados.

Outro aspecto que se destaca é a formação/capacitação de professor para a Educação do/no Campo em conformidade com a realidade da sala de aula, da quantidade de alunos, das disciplinas e séries diferentes encontradas nestes espaços. Arroyo (2007, p. 158) destaca que, historicamente, não houve uma preocupação que focasse a educação do campo $^{1}$, pois os programas de formação de professores são estruturados "dentro do modelo de escolarização formal e urbana", objetivando a garantia da reprodução das relações sociais de produção. Isto é, há uma valorização dos modelos que vem de fora, sobretudo os urbanos, como se eles fossem os únicos que podem ser aderidos.

Conforme a Política Nacional de Formação de Professores do Magistério da Educação Básica (BRASIL, 2010) no parágrafo único do artigo $5^{\circ}$, ressalta que a formação desses professores (campo) deverá ocorrer de forma concomitante a sua atuação profissional. Assim, auxiliando os alunos/discentes para uma melhor capacitação/formação para o atendimento deste público inserido/habitado no campo.

1 De acordo com Caldart (2008, p. 71) "a Educação do Campo nasceu como mobilização/pressão de movimentos sociais por uma política educacional para comunidades camponesas: nasceu da combinação das lutas dos Sem Terra pela implantação de escolas públicas nas áreas de Reforma Agrária com as lutas de resistência de inúmeras organizações e comunidades camponesas para não perder suas escolas, suas experiências de educação, suas comunidades, seu território, sua identidade". 
Deste modo, há um conjunto de disposições legais e de direitos à educação conquistada pelos povos do campo, com a sua luta coletiva do campesinato e prevalecendo seus direitos positivos no que diz respeito à legislação. Além das normatizações específicas, interligadas aos dispositivos da Constituição Federal (CF) de 1988. No artigo $6^{\circ}$ da CF, em que estabelece em vários aspectos direitos sociais a educação, bem como a saúde, a moradia e outros, ou seja, na forma desta Constituição.

E juntamente com o Movimento da Educação do Campo acumulou-se um contíguo importante de dispositivos legais que legitima e reconhece o direito a Educação no Campo com conformidade a Diretrizes Operacionais para a Educação Básica das Escolas no Campo: Resolução CNE/CEB n. ${ }^{\circ}$ 1/2002 e Resolução CNE/CBE n² 2/2008 (BRASIL, 2002; 2008). Parecer $n$. $^{0} 1 / 2006$ que reconhece os Dias Letivos da Alternância, também homologado pela CEB (BRASIL, 2006); Decreto n. ${ }^{\circ}$ 7.352/2010, que dispõe sobre Política Nacional de Educação do Campo e sobre o Programa Nacional de Educação da Reforma Agrária (Pronera) (BRASIL, 2010a). Em destaque destes dispositivos está o Decreto $n^{\circ} 7.357 / 2010$, que elevou a Educação no Campo a Política de Estado, por este conter artigos que compõe uma coluna estruturante de fins legais (BRASIL, 2010b).

Por isso, a Educação no Campo é direito legal/constituído no amparo de leis/programas/constituição que rege nacionalmente a Educação de todos daqueles (sujeitos) que estejam inseridos no âmbito educacional, seja ele no espaço urbano ou rural. Logo, a Educação no Campo advém de uma ação de conquistas/lutas protagonizadas pelos movimentos sociais do campo (camponesa) em que buscou construir e requerer uma prática educativa de direito legal na CF, objetivando o fortalecimento das questões dos processos escolares nas comunidades, nos diferentes níveis educativos e nos movimentos do campo sem perder sua essência do campesinato.

No entanto, observa-se nas últimas décadas uma migração da juventude camponesa em direção aos centros urbanos, especialmente em relação às jovens, fazendo com que a população do campo seja predominantemente mascu- 
lina e envelhecida. De acordo com o Censo Agropecuário de 2017 (IBGE, 2017) apenas $2 \%$ (100.357) dos produtores que dirigem suas propriedades rurais são jovens de até 25 anos, e entre esses jovens, 70,2\% (70.441) são do sexo masculino.

Nesse sentido, é importante compreender a dinâmica da educação do/no campo e a juventude que o habita; bem como analisar as características do jovem camponês/rural no Brasil e os aspectos que influenciam sua permanência ou não no campo; verificar os desafios da realidade da educação do/no campo na atualidade; e investigar de que maneira a educação ambiental no campo contribui com a permanência dos jovens no meio rural a partir da prática/manejo sustentável (agroecologia).

A temática proposta demandou um referencial teórico sobre a educação do/no campo no Brasil, como também em relação ao jovem camponês/rural e como a agroecologia tem contribuído com a sua permanência no campo. Assim, realizamos uma revisão bibliográfica com foco em subsidiar as reflexões a respeito da realidade da educação no/do campo, sobretudo a dos jovens.

\section{O JOVEM CAMPONÊS/RURAL NO BRASIL: FICAR OU SAIR?}

A decisão dos jovens em permanecer ou não no campo, geralmente, está relacionada a fatores como políticas públicas atraentes, proximidade e atratividade dos centros urbanos, direcionamento acadêmico estudantil no desenvolvimento das pequenas propriedades rurais, influências internas que dizem respeito à composição da família, tais como nível de riqueza, escolaridade, faixa etária e gênero, entre outros (ABRAMOVAY et al., 1998; SIMIONI, 2013; CASTRO, 2017).

Atualmente, a população que vive no campo está se tornando velha e masculinizada, porque os jovens, sobretudo as jovens, não querem mais permanecer no campo (BASTIANI; STRASSER, 2012). Para Dalcin e Troian (2009) dentre os motivos que levam à migração campo-cidade, a desvalorização feminina destaca-se quanto à decisão das mulheres de permanecer ou não no meio rural. As 
Tabelas 1 e 2 apresentam dados sobre a quantidade de estabelecimentos agropecuários dirigidos por homens e mulheres e a quantidade de pessoas ocupadas neles.

Tabela 1: Número de estabelecimentos agropecuários dirigidos pelo produtor de acordo com sexo e faixa etária no Brasil - 2017

\begin{tabular}{cccc}
\hline Sexo & Menores de 25 anos & De 25 anos ou mais & Total \\
\hline Homens & 70.441 & 4.040 .009 & 4.110 .450 \\
Mulheres & 29.916 & 916.159 & 946.075 \\
\hline Total & 100.357 & 4.956 .168 & $\mathbf{5 . 0 5 6 . 5 2 5}$ \\
\hline
\end{tabular}

Fonte: Censo Agropecuário de 2017 (IBGE, 2017).

Tabela 2: Número de pessoal ocupado em estabelecimentos agropecuários de acordo com sexo e faixa etária no Brasil - 2017

\begin{tabular}{cccc}
\hline Sexo & Menores de 14 anos & De 14 anos ou mais & Total \\
\hline Homens & 323.863 & 10.402 .243 & 10.726 .106 \\
Mulheres & 256.189 & 4.122 .830 & 4.379 .019 \\
\hline Total & $\mathbf{5 8 0 . 0 5 2}$ & $\mathbf{1 4 . 5 2 5 . 0 7 3}$ & $\mathbf{1 5 . 1 0 5 . 1 2 5}$ \\
\hline
\end{tabular}

Fonte: Censo Agropecuário de 2017 (IBGE, 2017).

A desvalorização feminina está relacionada à divisão de tarefas, bem como pelo fato da sucessão da propriedade rural dar-se geralmente ao filho homem, como vemos na Tabela 1, 81,3\% dos estabelecimentos agropecuários brasileiros são dirigidos por homens. A mulher é responsável por cuidar da casa, das crianças e preparar o alimento para a família. Isto é, ela é responsável pelo trabalho doméstico que não é remunerado e, geralmente visto como uma "ajuda" por não gerar renda.

Assim, a mulher fica subordinada ao pai e depois ao irmão, se ainda for solteira, independente dele ser mais novo ou mais velho que continuará adminis- 
trando a propriedade. Se casada, a subordinação continuará sob a dependência do marido (BASTIANI; STRASSER, 2012). A oferta de trabalho doméstico nas cidades é um dos motivos que faz com que as mulheres deixem o campo para se livrar da sujeição masculina, mesmo que continuem com os trabalhos domésticos, pois passam a ter seu próprio dinheiro, a sua independência financeira.

A sucessão paterna na propriedade rural, geralmente está relacionada ao gênero, escolaridade e a renda das famílias. Apesar de ainda existir, esse tipo de sucessão está se tornando cada vez mais ultrapassada, pois se percebe uma diminuição no número de jovens que permanecem no campo. De acordo com Barcellos (2015) cerca de 1 milhão de jovens entre 15 e 29 anos entre 2000 e 2010 deixaram o campo para viver na cidade. Em 2000, a população rural brasileira era de 31.835.143, dos quais aproximadamente 9 milhões eram jovens entre 15 e 29 anos, em 2010, dos 29.830.007 habitantes do campo, apenas cerca de 8 milhões era composta por jovens.

Com os processos de urbanização das cidades, o modo de vida tem se tornado mais urbano que rural e levado as áreas rurais a configurações híbridas (SPOSITO, 2006). Os camponeses não atuam mais somente no campo e, bem como não atuam somente na cidade, assim, são influenciados pela densidade tecnológica e buscam a emancipação em contextos adversos, principalmente se tratando dos jovens.

Para Savian (2014) a decisão de sair ou ficar no campo varia conforme os propósitos de cada pessoa, mas é influenciada pelo contexto social em que ela está inserida. O jovem como ator social ocupa posição de destaque nos discursos, porém não na prática, visto que as transformações na relação rural-urbano e o acesso à educação mais comumente urbana, por exemplo, são alguns dos motivos porque o trabalho no campo passou a ser uma opção e não mais uma necessidade entre os jovens (CASTRO, 2017).

Oliveira, Mendes e Vasconcelos (2021) identificaram três grandes categorias que influenciam a permanência do jovem no meio rural: $1^{\circ}$ ) histórico familiar e com o campo, que evidencia os conflitos, sentimentos e relações entre pais e 
filhos durante os anos de vida na propriedade rural; $2^{\circ}$ ) estímulos/obstáculos à permanência no campo, como a condição social e econômica da família e a atratividade do meio urbano; e $3^{\circ}$ ) perspectivas/alternativas/possibilidades, em que a decisão de permanecer na propriedade rural, ou não, é afetada diretamente pelo processo sucessório e as diversas relações que são estabelecidas entre rural-urbano.

É importante e necessário uma inovação política fundiária no Brasil, principalmente para que os milhares de jovens agricultores e agricultoras possam ter melhores oportunidades para realizar suas vocações e desejos profissionais (VANTROBA, 2009). Essa inovação pode vir da realização de uma reforma que contemple para os jovens: acesso a terra; crédito agrícola; infraestrutura; educação; capacitação e assistência técnica; lazer; etc.

A permanência dos jovens no campo está diretamente ligada à resistência ao modelo agroexportador brasileiro que, essencialmente, caracteriza-se pelo monocultivo e latifúndio e, cada vez mais, subordina a agricultura familiar a seus moldes. Trata-se de um modo de produção focado na exportação e no lucro, sem se preocupar com as implicações ambientais, sociais, culturais, econômicas e políticas, etc.

Buczenko e Rosa (2018) analisaram diversas pesquisas sobre a permanência dos jovens no campo relacionando-a com a educação no/do campo. Os autores identificaram que a decisão dos jovens em ficar no campo se dá conforme os seguintes fatores: incentivo familiar; trabalho cooperativo, sobretudo em produções agroecológicas; e a garantia de uma porção de terra para o seu futuro. No entanto, o fator educação se mostra frágil nos relatos das pesquisas analisadas para justificar a permanência dos jovens no campo.

No Brasil, ainda é muito presente a educação rural com perspectiva voltada, pensada e organizada para o meio urbano, totalmente desarticulada com as realidades socioespaciais das crianças e jovens que vivem no campo. Embora, haja muitos avanços e lutas pela educação do campo, ainda há um vasto caminho a ser percorrido para fortalecer a presença das escolas rurais, seus princípios e ideais de transformação social. 


\section{A EDUCAÇÃO NO CAMPO E A SUA REALIDADE}

A educação é uma prática social, uma atividade específica dos seres humanos, situando-os dentro da história. A educação por si só não muda o mundo, mas o mundo pode ser mudado pela sua ação na sociedade e nas relações de trabalho. A educação pode ser considerada como um processo para o desenvolvimento humano integral, geradora de transformações sociais. É fundamental e se constitui como uma base para a conquista da autonomia, da visão prospectiva e é fator de progresso político, econômico, social, cultural, dentre outros. Assim, ela integra o sentimento e a consciência de cidadania, possibilitando ao indivíduo analisar, compreender, apreender, intervir e ter uma visão crítica quanto à realidade em que ele está inserido, com vistas ao bem estar pessoal e coletivo.

Nesse contexto, a educação é um dos caminhos para que o jovem permaneça no campo e a agricultura não envelheça, como está acontecendo atualmente. Em que pese às lutas e conquistas dos movimentos sociais em defesa da educação do campo, presenciamos ainda no cenário nacional brasileiro uma política de fechamento de escolas rurais. Isto evidencia o preconceito existente quanto à educação do/no campo e do próprio modo de vida camponês.

A educação do campo no Brasil se constitui como um fenômeno que revela a ausência de uma reforma agrária, tão prometida, às vezes ensaiada, mas que até agora não foi consumada no país. Além disso, também evidencia o protagonismo das trabalhadoras e dos trabalhadores do campo e suas organizações, que lutam em defesa dos interesses sociais das comunidades camponesas. Para Caldart (2010, p. 107) a educação do campo é

[...] um movimento real de combate ao atual estado de coisas - movimento prático, de objetivos ou fins práticos, de ferramentas práticas, que expressa e produz concepções teóricas, críticas a determinadas visões de educação; de política de educação, de projetos de campo e de país, mas que são interpretações da realidade construídas com vistas a orientar ações/lutas concretas. 
Assim, a educação do campo emerge da práxis, pautada na luta camponesa com vistas à formação das novas gerações para a continuidade da vida no campo. No que diz respeito aos princípios da educação do campo, de acordo com o Movimento dos Trabalhadores Rurais Sem Terra (MST) (1997) destacam-se:

- Educação para a transformação social, buscando uma nova social cujos pilares sejam a justiça social, a radicalidade democrática e os valores humanistas e socialistas;

- Educação para o trabalho e a cooperação, no sentido de manter a luta pela reforma agrária e os desafios que coloca para implementação de novas relações de produção no campo e na cidade;

- Educação voltada para as várias dimensões da pessoa humana, ou seja, uma educação onilateral que se opõe à educação unilateral que se preocupa com um só lado ou dimensão da pessoa;

- Educação com/para valores humanistas e socialistas, que venha a romper com os valores dominantes da sociedade atual, centrada no lucro e no individualismo desenfreado;

- Educação como um processo permanente de formação e transformação humana, com base na crença no ser humano e na sua capacidade de transformação, condição básica para um processo de educação/formação.

Nesse sentido, pensar em educação do campo é pensar na coletividade, na valorização da diversidade cultural que marca a sociedade brasileira. A educação ambiental emerge dos movimentos sociais e imediatamente se contrapõe à lógica capitalista que coisifica tudo e todos. Também reivindica os direitos inalienáveis de todo cidadão para quem é do campo, incluindo-se ainda o direito a terra, historicamente negado num país que privilegia o latifúndio e a exploração da mão de obra.

Assim, a educação do campo é um dos pilares para a permanência dos jovens no meio rural, por sua capacidade de fortalecer a identidade camponesa desses jovens, contribuindo, também, com o fortalecimento da agricultura familiar 
e, consequentemente se constitui como resistência ao latifúndio. A perspectiva agroecológica tem demonstrado uma enorme contribuição nesse sentido, como veremos a seguir.

\section{PERSPECTIVA DA EDUCAÇÃO AMBIENTAL NO CAMPO PARA OS JOVENS (AGROECOLOGIA)}

De acordo com Caporal (2009) o modelo representado pelos monocultivos, pautado em tecnologias da Revolução Verde, provocou uma crise socioambiental que afeta toda a sociedade. A problemática em torno do desenvolvimento sustentável ganha relevo ao mesmo passo em que a qualidade de vida da população do campo é reduzida e os recursos naturais são degradados, como consequência da agricultura moderna (ALTIERI, 2004). Assim, a agroecologia surgiu e vem sendo construída a partir de uma demanda social, visto que o modelo de produção vigente causa implicações socioambientais extremamente negativas.

A agroecologia busca "[...] orientar estratégias de desenvolvimento rural mais sustentável e de transição para estilos de agriculturas mais sustentáveis, como uma contribuição para a vida das atuais e das futuras gerações neste planeta de recursos limitados" (CAPORAL, 2009, p. 2). Para Gliessman (2008) a agroecologia possui uma abordagem mais integradora e abrangente, sendo um espaço de conhecimento que promove a interligação entre várias disciplinas que devem contribuir com o desenho e manejo dos agroescossistemas sustentáveis.

Uma agricultura sustentável e produtiva não deve abandonar todas as práticas convencionais, mas sim promover uma integração de conhecimentos. Isto é, utilizar conhecimentos ecológicos modernos ao mesmo tempo em que resgata e valoriza os conhecimentos e saberes dos povos e comunidades tradicionais.

Um estudo realizado por Oliveira e Schneider (2009) buscou analisar se a agroecologia tem gerado impactos sobre a presença e ocupações dos jovens no campo e as possibilidades de sucessão hereditárias dessas unidades familiares. Os autores observaram que 
[...] a inserção na agroecologia, e a diversificação de atividades dela decorrentes, têm gerado um retorno à centralidade do trabalho no que se refere à quantidade requerida, o que cria novas condições para a manutenção de mais pessoas vivendo e trabalhando nas propriedades, inclusive de jovens (novos empregos produtivos no meio rural) e, assim, novas oportunidades em termos de reprodução social (OLIVEIRA; SCHNEIDER, 2009, p. 21).

Conforme Oliveira e Schneider (2009) as famílias ecologistas possuíam mais pessoas trabalhando e residindo nas unidades produtivas e que, em relação aos jovens que ainda vivem e trabalham no lote, o número é superior no grupo dos produtores ecologistas. Isto indica que as famílias ecologistas têm tido meIhores condições de empregar todos os membros da família, especialmente os jovens, criando meios para mantê-los nas unidades produtivas.

Tanto a agroecologia quanto a educação do campo partem da concepção de valorização do conhecimento dos povos do campo como fundamento para uma ação transformadora e emancipadora dos sujeitos. Segundo Souza (2008) a educação do campo considera os conhecimentos da realidade camponesa e concebe o campo como lugar de trabalho, moradia, identidade, sociabilidade, lazer, enfim, como lugar da criação de novas possibilidades de reprodução social e de desenvolvimento sustentável.

A agroecologia e a educação do campo possuem a mesma base social de construção inicial: ambas são marcadas pela resistência dos agricultores familiares camponeses e seu processo de reorganização mediante os movimentos sociais. Para Caporal e Petersen (2011) uma das características marcantes da agroecologia no Brasil é o vínculo com a defesa da agricultura familiar camponesa como base social de modelos sustentáveis de desenvolvimento rural. A educação do campo também se estabelece a partir dessa base social, questionando as práticas pedagógicas de uma "educação" que foi prescrita e imposta aos povos do campo durante anos (CALDART, 2008).

A educação direcionada à população rural tem relação direta com a permanência dos jovens no campo, pois ao considerar a realidade do público que atende estará contribuindo com o fortalecimento da identidade do jovem enquan- 
to agricultor (BASTIANI; STRASSER, 2012). Ao tornar o campo mais atrativo aos jovens, a educação do campo com enfoque agroecológico contribuirá com a continuidade da agricultura familiar enquanto forma de resistência ao modo de produção capitalista e os seus ditames.

\section{CONSIDERAÇÕES FINAIS}

Percebemos que a educação do/no campo possui princípios que conversam com os princípios agroecológicos como a busca de um desenvolvimento social, economicamente justo e ecologicamente sustentável. A condição de pensar o campo a partir da realidade do campo possibilita, entre outros aspectos, a manifestação da coletividade e a luta por políticas públicas que atendam aos interesses dos povos do campo, ampliando também as condições de permanência dos jovens nesse contexto; seja pela atuação do cooperativismo, da agricultura familiar; seja pela perspectiva de posse da terra ou até mesmo da agroecologia.

Assim, o movimento da educação do campo vem construindo as bases pedagógicas com enfoque agroecológico enfatizando a crítica ao modelo de produção convencional, a ruptura de paradigma em relação a esse modelo, a concepção pedagógica que valorize os territórios e os conhecimentos dos povos do/ no campo, bem como uma formação que consiga dialogar com a realidade camponesa afim transformá-la em prol do bem coletivo.

\section{REFERENCIAS}

ABRAMOVAY, R. et al. Juventude e agricultura familiar: desafios dos novos padrões sucessórios. Brasília: Unesco, 1998.

ALTIERI, M. Agroecologia: a dinâmica produtiva da agricultura sustentável. 4. ed. Porto Alegre: Editora da UFRGS, 2004.

ARGENTON, G, T. Educação do Campo: garantias de direitos em tempos pandemia. Brasil de Fato, Porto Alegre, s./p., 16 jun. 2020. Disponível em: https:// www.brasildefators.com.br/2020/06/16/artigo-educacao-do-campo-garantia-de-direitos-em-tempos-de-pandemia. Acesso em: 9 maio 2021. 
ARROYO, M. G. Políticas de formação de educadores(as) do campo. Caderno Cedes, Campinas, v. 27, n. 72, p. 157-176, maio/ago., 2007. Disponível em: https://www.scielo.br/j/ccedes/a/jL4tKcDNvCggFcg6sLYJhwG/?lang=pt\&format=pdf. Acesso em: 8 maio 2021.

BARCELLOS, S. B. A formulação das políticas públicas para a juventude rural no Brasil e os elementos constitutivos desse processo social. Mundo Agrário, São Paulo, v. 16, n. 32, p. 1-32, 2015. Disponível em: www.mundoagrario.unlp.edu.ar/ article/download/MAv16n32a10/6863/. Acesso em: 10 out. 2021.

BASTIANI, T. M.; STRASSER, R. B. Permanência dos jovens do campo: para que? In: SEMINÁRIO INTERNACIONAL E FÓRUM DE EDUCAÇÃO DO CAMPO DA REGIÃO SUL DO RS, 1, 1., 2012, Pelotas. Anais [...]. Pelotas, p. 1-13, 2012. Disponível em: http://coral.ufsm.br/sifedocregional/images/Anais/Eixo\%20 08/T\%C3\%A2nia\%20Mara\%20De\%20Bastiani.pdf. Acesso em: 6 out. 2021.

BRASIL. Constituição da República Federativa do Brasil de 1988. Presidência da República, Casa Civil, Subchefia para Assuntos Jurídicos, Brasília, 1988. Disponível em: http://www.planalto.gov.br/ccivil_03/constituicao/consituicaocompilado.htm. Acesso em: 2 out. 2021.

BRASIL. Ministério da Educação (MEC). Decreto n. $^{\circ}$ 7.352, de 4 de novembro de 2010. Dispõe sobre a Política Nacional de Educação do Campo e sobre o Programa Nacional de Educação na Reforma Agrária (PRONERA). Diário Oficial da União, Brasília, 4 nov. 2010a. Disponível em: http://portal.mec.gov.br/docman/ marco-2012-pdf/10199-8-decreto-7352-de4-de-novembro-de-2010/file. Acesso em: 9 maio 2021.

BRASIL. Decreto $\mathbf{n}^{\circ} \mathbf{7 . 3 5 7}$, de 17 de novembro de 2010. Dispõe sobre o Programa Nacional de Incubadoras de Cooperativas Populares - PRONINC, e dá outras providências. Presidência da República, Casa Civil, Subchefia para Assuntos Jurídicos, Brasília, 2010b. Disponível em: http://www.planalto.gov.br/ccivil_03/_ato2007-2010/2010/decreto/d7357.htm. Acesso em: 4 set. 2021.

BRASIL. Ministério da Educação (MEC). Lei n. ${ }^{0}$ 9.394, de 20 de dezembro de 1996. Estabelece as Diretrizes e Bases da Educação Nacional. Brasília: MEC, 1996. Disponível em: http://portal.mec.gov.br/seesp/arquivos/pdf/lei9394_Idbn1. pdf. Acesso em: 9 maio 2021. 
BRASIL. Parecer n. ${ }^{0}$ 1/2006. Dias letivos para a aplicação da Pedagogia de Alternância nos Centros Familiares de Formação por Alternância (CEFFA). Ministério da Educação, Conselho Nacional de Educação, Brasília, 2006. Disponível em: http://portal.mec.gov.br/cne/arquivos/pdf/pceb001_06.pdf. Acesso em: 7 out. 2021.

BRASIL. Resolução CNE/CEB 1, de 3 de abril de 2002. Institui Diretrizes Operacionais para a Educação Básica nas Escolas do Campo. Conselho Nacional de Educação, Câmara de Educação Básica, Brasília, 2002. Disponível em: http:// portal.mec.gov.br/index.php?option=com_docman\&view=download\&alias=13800-rceb001-02-pdf\&category_slug=agosto-2013-pdf\&Itemid=30192. Acesso em 9 maio 2021.

BRASIL. Resolução n $^{\circ}$ 2, de 28 de abril de 2008. Estabelece diretrizes complementares, normas e princípios para o desenvolvimento de políticas públicas de atendimento da Educação Básica do Campo. Ministério da Educação, Conselho Nacional de Educação, Câmara de Educação Básica, Brasília, 2008. Disponível em: http://portal.mec.gov.br/index.php?option=com_docman\&view=download\&alias=11841-rceb002-08-pdf\&category_slug=outubro-2012-pdf\&lte$\mathrm{mid}=30192$. Acesso em 9 maio 2021

BUCZENKO, G. L.; ROSA, M. A. A permanência do jovem no campo: contribuições da educação do/no campo. Revista Ensaios Pedagógicos, São Carlos, v. 8, n. 1, p. 1-20, jul., 2018. Disponível em: https://www.opet.com.br/faculdade/revista-pedagogia/pdf/v8/v8-artigo-1-A-PERMANENCIA-DO-JOVEM-NO-CAMPO. pdf. Acesso em: 5 jun. 2021.

CALDART, R. S. Educação do campo: notas para uma análise de percurso. In: MOLINA, M. C. (org.). Educação do campo e pesquisa II: questões para reflexão. Brasília, DF: MDA/MEC, 2010.

CALDART, R. S. Sobre educação do campo. In: SANTOS, C. A. D. (org.). Por uma educação do campo: campo, políticas públicas e educação. Brasília: INCRA/MDA, v.7, 2008, p. 67-86. Disponível em: http://webcache.googleusercontent.com/search?q=cache:1ZTN1Vxs2TUJ:nead.mda.gov.br/download. php\%3Ffile\%3Dpublicacoes/especial/por_uma_educacao_do_campo.pdf+\&c$\mathrm{d}=1 \& \mathrm{hl}=$ pt-BR\&ct=clnk\&gl=br. Acesso em: 3 jul. 2021.

CAPORAL, F. R. Agroecologia: uma nova ciência para apoiar a transição a agriculturas mais sustentáveis. Brasília: 2009. 
CAPORAL, F.R.; PETERSEN, P. Agroecologia e políticas públicas na América Latina: o caso do Brasil. Agroecologia, Murcia v. 6, p. 63-74, jan./dez., 2011. Disponível em: https://revistas.um.es/agroecologia/article/view/160681. Acesso em: 20 out. 2021.

CASTRO, E. G. D. Entre ficar e sair: uma etnografia da construção social da categoria jovem rural. Rio de Janeiro: Contra Capa, 2017.

DALCIN, D.; TROIAN, A. Jovem no meio rural a dicotomia entre sair e permanecer: um estudo de caso. In: SEMINÁRIO NACIONAL SOCIOLOGIA \& POLÍTICA, 1, 2009, Curitiba. Anais [...]. Curitiba: Sociedade e Política em tempos de Incerteza, s./p., 2009.

GLIESSMAN, S. R. Agroecologia: processos ecológicos em agricultura sustentável. Porto Alegre: Editora UFRGS, 2008.

GTI, Grupo de Trabalho Interinstitucional. Educação infantil do campo: proposta para a expansão da política. Portaria Interministerial número 6/2013. Ministérios de Estado da Educação, do Desenvolvimento Agrário e do Desenvolvimento Social e Combate à Fome Brasília, 2014. Disponível em: http://portal.mec.gov.br/ docman/agosto-2014-pdf/16264-gti-educacao-infantil-campo-09-04-pdf. Acesso em: 14 out. 2021.

IBGE. Instituto Brasileiro de Geografia e Estatística. Censo agropecuário 2017. Disponível em: https://sidra.ibge.gov.br/pesquisa/censo-agropecuario/censo-agropecuario-2017. Acesso em: 6 out. 2021.

MST. Movimento social dos Trabalhadores Sem Terra. Princípios da Educação do MST. São Paulo: Caderno de Educação, 1997.

OLIVEIRA, D.; SCHNEIDER, S. O futuro das unidades familiares: uma análise das possibilidades de sucessão hereditária entre os agricultores ecologistas de Ipê/RS. Revista Brasileira de Agroecologia, Curitiba v. 4, n. 2, p. 1293-1297, 2009. Disponível em: http://revistas.abaagroecologia.org.br/index.php/rbagroecologia/article/view/8214. Acesso em: 9 out. 2021.

OLIVEIRA, M. F.; MENDES, L.; VASCONCELOS, A. C. V. H. Desafios à permanência do jovem no meio rural: um estudo de casos em Piracicaba-SP e Uberlândia-MG. Revista de Economia e Sociologia Rural, Brasília v. 59, n. 2, 2021. https://doi.org/10.1590/1806-9479.2021.222727. Disponível em: https://www. scielo.br/j/resr/a/rqJZYYn8tbSbMnF9CgDXwbQ/?lang=pt. Acesso em: 16 set. 2021. 
SAVIAN, M. Sucessão geracional: garantindo-se renda continuaremos a ter agricultura familiar? Revista Espaço Acadêmico, Maringá, v. 14, n. 159, p. 97-106, ago., 2014. Disponível em: https://www.semanticscholar.org/paper/Sucess\%C3\%A3o-geracional\%3A-garantindo-se-renda-a-ter-Savian/8cbbd4013e7510e5e29799a635335d13d25341b2. Acesso em: 16 set. 2021.

SIMIONI, F. J. Determinantes da renda familiar no espaço rural: uma revisão. Organizações Rurais \& Agroindustriais, Lavras, v. 15, n. 3, p. 397-410, 2013. Disponível em: http://www.spell.org.br/documentos/ver/21697/determinantes-da-renda-familiar-no-espaco-rural--uma-revisao. Acesso em: 12 set. 2021.

SOUZA, M. A. de. Educação do campo: políticas, práticas pedagógicas e produção científica. Educação \& Sociedade, Campinas, v. 29, n. 105, p. 1089-1111, set./dez., 2008. Disponível em: https://www.scielo.br/j/es/a/6S89N7H4cTJRZTbnvykF5rt/?lang=pt\&format=pdf. Acesso em: 12 set. 2021.

SPOSITO, M. E. B. A questão cidade-campo: perspectiva a partir da cidade. In: SPOSITO, M. E. B; WHITACKER, A (org.). Cidade e campo: relações e contradições entre urbano e rural. São Paulo: Expressão Popular, 2006, p. 111-130.

VANTROPA, E. A. Necessidades e perspectivas para a permanência do jovem do campo no seu ambiente. 2009. Disponível em: http://www.diaadiaeducacao.pr.gov.br/portals/pde/arquivos/2447-8.pdf. Acesso em: 5 out. 2021. 


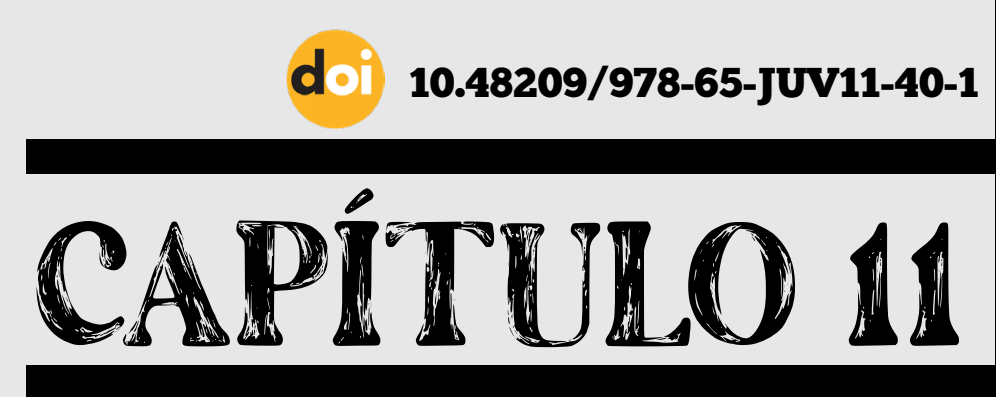

\title{
JUVENTUDE, MOVIMENTOS SOCIAIS E EDUCAÇÃO: A PARTICIPAÇÃO POLÍTICA DOS JOVENS NAS OCUPAÇÕES ESTUDANTIS EM GOIÁS
}

\author{
Amanda Beatriz Silva de Godoi \\ Rafael Ribeiro dos Santos \\ Rita Castorina Gonçalves Gundim Lemes
}

$1 \quad$ O artigo é resultado de reflexões que estão associadas à dissertação de Mestrado intitulada "Ocupações: luta e resistência estudantil em Goiás", de Amanda Beatriz Silva de Godoi, defendida no âmbito do Programa de Pós-Graduação em Sociologia (PPGS), da Faculdade de Ciências Sociais (FCS) da Universidade Federal de Goiás (UFG) em 2021. Vincula-se também ao projeto de pesquisa intitulado "Linguagens urbanas: os jovens, suas espacialidades e redes de sociabilidade em Anápolis-GO", coordenado pela Profa. Dra. Mary Anne Vieira Silva (PPGTECCER/UEG), aprovado junto a Pró-Reitoria de Pesquisa e Pós-Graduação (PrP) da Universidade Estadual de Goiás (UEG). 


\section{INTRODUÇÃO}

Os movimentos das ocupações estudantis foram realizados a partir do final do ano de 2015 e em 2016, em diversos estados do Brasil, a exemplo de São Paulo (SP), Goiás (GO), Rio Grande do Sul (RS), Paraná (PR) e Rio de Janeiro (RJ). O objetivo principal da mobilização estudantil foi à contrariedade as pautas educativas dos governos estaduais de Geraldo Alckmin (SP), Marconi Perillo (GO), José Ivo Sartori (RS), Carlos Alberto Richa (PR) e Luiz Fernando Pezão (RJ).

Outras ocupações de escolas e Instituições de Ensino Superior (IES) ocorreram durante os meses de outubro, novembro e dezembro de 2016. O motivo central foi à posição contrária a Medida Provisória (MP) 746/2016, posteriormente convertida em Lei $n^{\circ} 13.415 / 201$, que previa a reestruturação/reforma do Ensino Médio (BRASIL, 2016a); assim como a Proposta de Emenda Constitucional (PEC) $241^{1}$ (ou PEC 55), conhecida como "PEC do Teto", que limita o aumento dos gastos públicos no país por 20 anos, afetando drasticamente o orçamento da educação, saúde e demais serviços públicos no país.

Outra reivindicação foi contra a criação do Projeto de Lei $(\mathrm{PL})$, denominado “Escola sem Partido". Apresentado na câmara dos deputados em junho de 2016, o projeto buscava limitar a atuação docente no intuito de impedir que os professores expusessem e promovessem suas ideologias e preferências partidárias em sala de aula, ou mesmo incitassem os alunos a participarem de manifestações de ordem popular.

No entanto, é preciso reconhecer que toda opinião ou posição que alguém expressa, ocasionalmente, é alicerçada em fatores históricos, culturais e sociais, e que evidenciam os valores de um determinado grupo. Isto é, qualquer sujeito ao expor suas ideias e concepções, que são historicamente estruturadas e concebidas, indiscutivelmente estará pautado em uma determinada escolha,

1 Mediante a sua aprovação, a PEC 241 foi transformada na Emenda Constitucional (EC) $\mathrm{n}^{\circ}$ 95, de 15 de dezembro de 2016 (BRASIL, 2016b). 
situada no tempo e no espaço, e marcada por princípios individuais e coletivos. Portanto, a defesa por uma "escola sem partido" só transparece o movimento político que visa avançar e promover as perspectivas e ideologias de uma agenda conservadora de grupos que buscam implementar medidas retrógadas na educação brasileira, sobretudo a partir da negação do que é divergente aos seus princípios.

Os pesquisadores sobre o tema das ocupações distinguiram em duas ondas esses atos que ocorreram em 2015 e 2016. Ambos tiveram como característica marcante a longa duração das ocupações, chegando há meses, diferente do que a cartilha "Como ocupar um colégio" orienta. A primeira onda, conforme Groppo (2018), ocorreu entre dezembro de 2015 e junho de 2016, tendo o seu enfoque na oposição a políticas estaduais (conforme ressaltado anteriormente) e foi desenvolvida a partir da ação política de jovens estudantes do Ensino Médio.

A segunda onda de ocupações estudantis, ocorrida entre outubro e dezembro de 2016, possuiu uma abrangência de caráter nacional, contou com o apoio de representantes de diferentes estados. No caso de Goiás, ao se aliarem a luta nacional contra a MP 746/2016 e a PEC 241, os manifestantes englobaram suas reivindicações estaduais a pauta. Nesse caso, houve também a retomada da luta contra a instalação das Organizações Sociais (OS) na administração da educação pública estadual.

Nesse sentido, o objetivo deste artigo é de compreender como a participação política juvenil nas ações contestatórias referentes à segunda onda de ocupações secundaristas em Goiás foi abordada pela mídia nas páginas de jornais. Pois, verifica-se que durante o período em que as instituições de ensino foram ocupadas em Goiás por conta da luta contra a PEC 241/2016 e a MP 746/2016, veículos de informação trouxeram as ocupações como pauta de suas notícias.

1 Essa cartilha foi desenvolvida por estudantes do Chile e da Argentina, dando orientações sobre como ocupar um colégio. A experiência vivenciada por esses estudantes desses dois países serviu de exemplo para as lutas empreendidas no Brasil (COMO OCUPAR UM COLÉGIO, 2015). 
Logo, selecionamos no período posterior as ocupações de escolas, reportagens publicadas nas páginas virtuais de alguns jornais, como: Jornal Estado de Goiás, Diário da Manhã, G1-GO e Jornal Opção.

A temática abordada exigiu um referencial teórico que tratasse sobre educação e movimentos sociais, assim como a atuação dos jovens nesse processo e como eles contribuíram junto às reinvindicações das pautas apresentadas naquele período. Assim, realizamos uma revisão bibliográfica com foco em subsidiar as reflexões a respeito das ocupações estudantis, sobretudo no que diz respeito à posição política evidenciada pelos jovens na luta pela educação pública e de qualidade.

Para isso, o artigo se estrutura inicialmente a partir de uma análise teóricoconceitual sobre o conceito de juventude e a sua participação política frente às ocupações estudantis. Buscamos discutir também sobre os movimentos sociais e a educação. Por fim, nos pautamos em analisar seis matérias jornalísticas dos veículos de comunicação descritos anteriormente, a fim de verificar como as ocupações e as suas motivações políticas foram retratadas na mídia.

\section{JUVENTUDE E EDUCAÇÃO: ENTRE TENSÕES E LUTAS POLÍTICAS}

A juventude é uma categoria ampla e complexa, cujos critérios que a constituem são históricos e sociais, e que ao longo do tempo e do espaço é atravessada por diferentes transformações, que envolvem questões históricas e culturais (DAYRELL, 2003; CASSAB, 2011). Enquanto construção social a juventude faz parte da estrutura da sociedade, e é uma das categorias essenciais para compreensão da mesma.

A construção social da juventude não acontece de forma universal, ela é concebida na sociedade no decorrer da história e de diferentes formas, especialmente em virtude dos jovens serem produtos das relações que eles estabelecem com os seus semelhantes e com o mundo, em um processo dialético de trocas 
e interações. Na sociedade capitalista, por exemplo, ela "[...] é concebida como um período de vigilância, disciplinarização e socialização do indivíduo entre sua infância e idade adulta" (CASSAB, 2011, p. 156). Portanto, o jovem é constituído através do entrecruzamento do eu com o mundo, e do outro com o eu, o que ocorre por meio de mediações, relações que conformam suas experiências juvenis e de subjetivação.

Nesse sentido, de acordo com Elias (1994, s./p.), "[...] o indivíduo sempre existe, no nível mais fundamental, na relação com os outros, e essa relação tem sua estrutura particular que é específica de sua sociedade". O autor ainda acrescenta, ao afirmar que assim "ele adquire sua marca individual a partir da história dessas relações, dessas dependências, e assim, num contexto mais amplo, da história de toda a rede humana em que cresce e vive" (ELIAS, 1994, s./p.). E essas relações também se fundam e desenvolvem no âmbito da educação, que por sinal, é também uma esfera de sociabilidade, de interatividade entre os sujeitos, sobretudo os jovens.

Assim, buscamos analisar a juventude no contexto da educação, compreendida aqui como um processo amplo e que ocorre em variados espaços, sejam eles formais ou não. No que tange a prática educativa voltada aos movimentos sociais, ela se difere daquela que ocorre em espaços formais no âmbito das instituições de educação, sobretudo por ser construída no decorrer da vida do indivíduo, por meio de suas experiências de luta (LUCENA; CARAMELO; SILVA, 2019).

As transformações que ocorrem na sociedade capitalista agravam as desigualdades e repercutem em lutas, manifestações, mobilizações, entre outras expressões de recusa ao que está sendo posto. Os movimentos sociais exercem um papel importante nesse cenário, em que a prática educativa que ocorre no interior destes movimentos, reflete no aprendizado dos direitos. Conforme Arroyo (2003), os movimentos sociais foram responsáveis por inserir setores populares da sociedade na escola pública. Os movimentos sociais lutam por uma escola 
que em tese está garantida no campo do direito, assim como a saúde, a moradia, a terra, a segurança, a proteção da infância, a cidade.

Ainda sobre a influência dos movimentos sociais nas lutas pela educação, Arroyo (2003) esclarece que o papel exercido pelos movimentos sociais,

\begin{abstract}
têm sido educativos não tanto através da propagação de discursos e lições conscientizadoras, mas pelas formas como tem agregado e mobilizado em torno das lutas pela sobrevivência, pela terra ou pela inserção na cidade. Revelam à teoria e ao fazer pedagógicos a centralidade que tem as lutas pela humanização das condições de vida nos processos de formação. Nos relembram quão determinantes são, no constituir-nos seres humanos, as condições de sobrevivência. A luta pela vida educa por ser o direito mais radical da condição humana. (ARROYO, 2003, p. 32).
\end{abstract}

O pensar e o fazer educativo, nos movimentos sociais revelam a necessidade em colocar o foco da ação nos sujeitos sociais em formação, sujeitos em movimento, em ação coletiva (ARROYO, 2003). A experiência educativa que ocorre na participação em movimentos sociais, ao tratar de direitos sociais, propicia o reconhecimento dos sujeitos, principalmente no que diz respeito aos seus direitos e deveres individuais e coletivos (LUCENA; CARAMELO; SILVA, 2019).

Para Arroyo (2003) os movimentos fundamentam um difícil diálogo entre os conhecimentos construídos no contexto social em relação às especificidades da vida humana. Assim, o autor adverte que a pluralidade de sujeitos sociais, bem como as suas ações que constituem e traçam a história, possuem maneiras distintas de conhecer as diferentes espacialidades, seja no campo ou na cidade, a história na qual atuam como protagonistas.

O movimento estudantil exerce um papel importante no processo de educação/formação dos jovens que participam dele, não se limitam apenas ao sentido estrito do termo que se refere à educação formal, mas influência também na educação no sentindo amplo enquanto socialização dos jovens que estão sendo preparados para integrar a sociedade com responsabilidade social.

O destaque que o movimento estudantil recebe aqui pauta-se por concordarmos com Peixoto (2016), que compreende que dentre os movimentos sociais 
que atuam no processo de formação individual dos estudantes, o movimento estudantil é um espaço privilegiado e que atua na formação e ressocialização dos estudantes, enquanto processo inovador/diferenciador/reforçador da educação formal. Para Peixoto (2016, p. 173)

Um dos elementos presentes na ressocialização via movimento estudantil são os laços sociais, as relações sociais instituídas nesse processo. A participação no movimento estudantil cria novas relações. Possibilita, por exemplo, as de disputa eleitoral e política, na qual a oralidade ganha importância, as afetivas e festivas, que é entre pessoas em situação semelhante - estudantes e, portanto, no qual há um processo de comunicação que entra não apenas no cotidiano do movimento estudantil e das relações dos indivíduos mais próximos, já que também envolve as questões políticas e acadêmicas.

Dessa forma, a convivência social dos estudantes amplia o seu nível de engajamento e participação política nas lutas coletivas. A experiência e os aprendizados constituídos a partir do envolvimento com movimentos sociais educam os sujeitos em formação para além do currículo elaborado para atender as necessidades do Estado a serviço do capitalismo que sãos ministrados em instituições formais de ensino. Esse aprendizado ocorre no decorrer da vida do indivíduo e atua no sentido de auxiliar na construção da consciência dos envolvidos enquanto sujeitos de direitos e deveres na sociedade.

\section{A REPRESENTAÇÃO DAS OCUPAÇÕES ESTUDANTIS NA MÍDIA}

Diante das lutas estudantis em Goiás, os veículos digitais de comunicação produziram algumas reportagens com base na temática. No quadro da ilustração 01 descrevemos as reportagens selecionadas no período posterior as ocupações das escolas, as quais serão analisadas nesta seção, no intuito de compreender como esses movimentos formados e coordenados pelos jovens eram retratados na mídia. 
Ilustração 01: Quadro - Reportagens sobre as ocupações estudantis em Goiás (2016)

\begin{tabular}{|c|c|c|}
\hline $\begin{array}{c}\text { Títulos das } \\
\text { reportagens }\end{array}$ & $\begin{array}{c}\text { Veículos de } \\
\text { comunicação }\end{array}$ & $\begin{array}{c}\text { Data da publicação } \\
\text { original }\end{array}$ \\
\hline $\begin{array}{c}\text { O dia a dia da ocupação } \\
\text { no Instituto Federal } \\
\text { de Goiás }\end{array}$ & Jornal Estado de Goiás & 14 de novembro de 2016 \\
\hline $\begin{array}{c}\text { Aulas da liberdade } \\
\text { Estudantes nas ruas contra } \\
\text { reforma estudantil }\end{array}$ & Diário da manhã & 26 de outubro de 2016 \\
\hline $\begin{array}{c}\text { Estudantes protestam } \\
\text { contra reforma do ensino } \\
\text { médio e a PEC } 241 \text { em Go }\end{array}$ & G1-Go & 19 de outubro de 2016 \\
\hline $\begin{array}{c}\text { Enem pode ser adiado em } \\
\text { mais escolas. Inep divulga } \\
\text { nova lista na sexta-feira (4) }\end{array}$ & Jornal Opção & 03 de novembro de 2016 \\
\hline $\begin{array}{c}\text { Enem será adiado para } \\
240 \text { mil candidatos por } \\
\text { causa de ocupações } \\
\text { de escolas }\end{array}$ & Jornal Opção & 04 de novembro de 2016 \\
\hline
\end{tabular}

Elaboração e organização dos dados: os autores (2021).

No decorrer do processo de seleção das reportagens foi possível identificar um problema comum e relacionado ao trabalho de pesquisa em material divulgado em plataformas digitais: a rápida exclusão ou remanejo. Ao procurar por palavras-chave nas páginas de pesquisa dos jornais, como "ocupações de escolas", "ocupações secundaristas", "estudantes ocupam escolas", entre outros, foi 
possível perceber que os links não direcionavam especificamente para algumas matérias que haviam sido citadas por outros jornais e/ou páginas do Facebook das ocupações.

\section{“O DIA A DIA DA OCUPAÇÃO NO INSTITUTO FEDERAL DE GOIÁS"}

Na reportagem intitulada "O dia a dia da ocupação no Instituto Federal de Goiás", publicada pelo Jornal Estado de Goiás, Rosa (2016) relata que as ocupações de instituições públicas de ensino em Anápolis (GO), começaram no dia 11 de outubro (ver ilustração 02). O foco desta reportagem eram as instituições de nível superior, por isso ele cita como exemplo os casos das ocupações do Instituto Federal de Goiás (IFG) e da Universidade Estadual de Goiás (UEG), no Campus de Ciências Socioeconômicas e Humanas (CCSEH) (atual Unidade Universitária de Anápolis - Ciências Socioeconômicas e Humanas (UnUCSEH)).

Ilustração 02: Fotografia - Jovens secundaristas em momento de diálogo durante a ocupação do Instituto Federal de Goiás, Anápolis (GO)

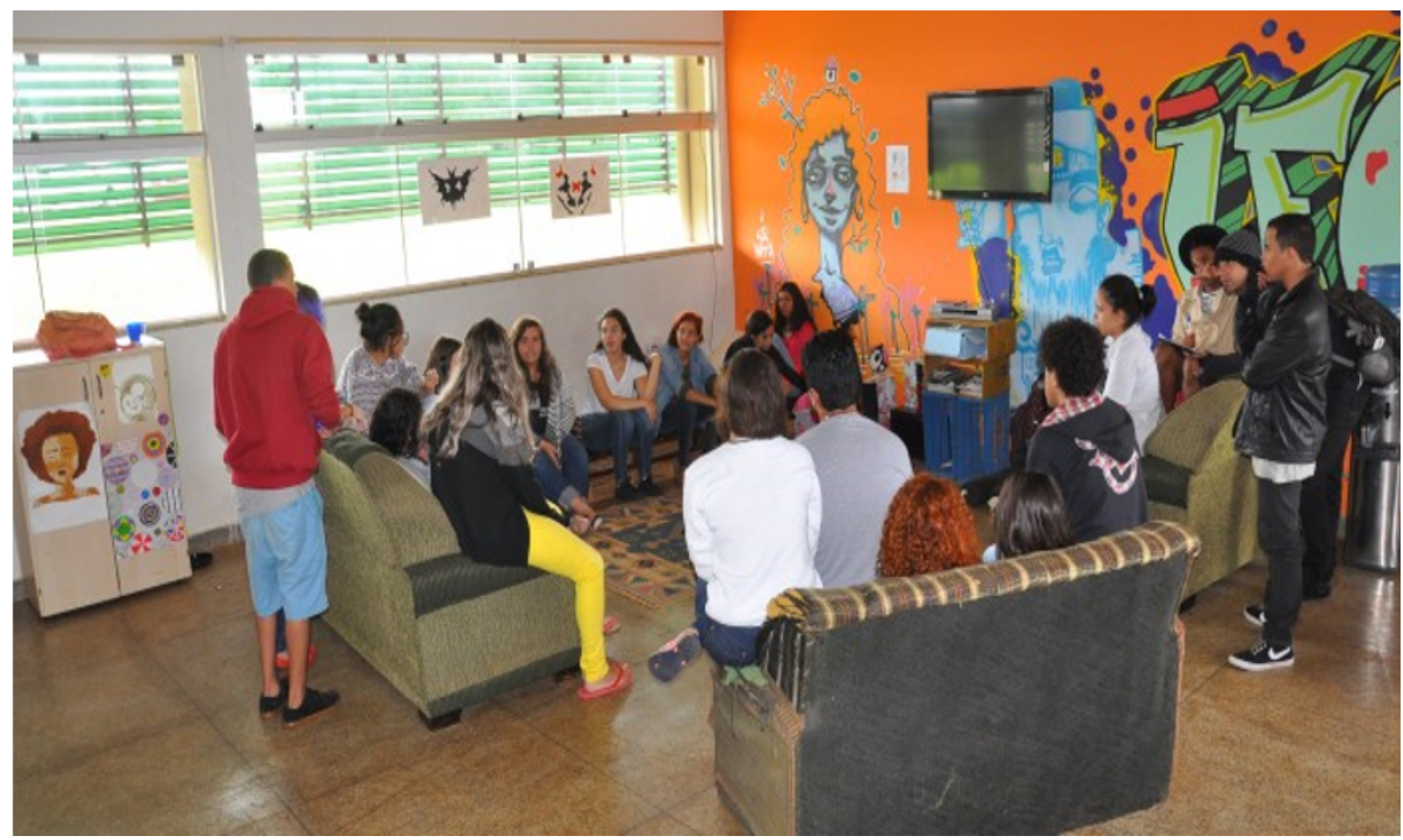

Fonte: Rosa (2016, s./p.). Disponível em: https://www.jornalestadodegoias.com.br/2016 /11/14/ o-dia-a-dia-da-ocupacao -no-instituto-federal-de-goias/. Acesso em: 26 abr. 2021. 
De acordo com Pesavento (2006, p. 57) a fotografia conta "[...] como portas ou janelas de entrada para o passado, para além do seu valor de documento, que conferiria à imagem o conteúdo de prova". Nesse contexto, a ilustração 02 mostra a interação e diálogo dos jovens secundaristas no momento da ocupação, o que possibilita ampliar a visão acerca do movimento, verificando um momento de diálogo e organização do grupo.

A pauta reivindicava e de contrariedade a PEC 55 e o andamento da votação sobre a mesma no Senado é abordado na reportagem, que traz aspectos gerais sobre as ocupações no IFG, que naquele momento (14 de novembro de 2016) já duravam mais de um mês. A votação pela ocupação também é abordada na matéria, além de destaques com informações sobre o curso de vinculação dos estudantes, que, majoritariamente eram acadêmicos de Química e Ciências Econômicas (ROSA, 2016). Além disso, o autor da matéria destaca a preocupação dos ocupas ${ }^{1}$ em relação aos alunos do Ensino Médio que fariam o Enem (Exame Nacional do Ensino Médio) naquele ano; a realização de aulões; criação de comissões específicas para organização do movimento e de espaços voltados para o desenvolvimento de atividades culturais.

A reportagem ainda destaca a fala da estudante Bárbara Abreu (15 anos na época), que participou da ocupação no IFG Anápolis, intercalando trechos do seu depoimento com a análise do autor (ROSA, 2016). A ocupa fala sobre a possibilidade de aprovação da PEC no Congresso, e sobre os desejos dos ocupas em chamar a atenção dos legisladores federais e da população para a gravidade da situação a partir das ocupações. Para Bárbara "essa persistência no movimento está na contrariedade com o impacto da PEC na área da Educação, como também que participemos do debate da reforma do ensino médio" (ROSA, 2016, s./p.).

O professor de História, André Conrado, do IFG Anápolis, apoiador das ocupações também foi entrevistado. O docente falou sobre o movimento

1 Durante as ocupações, os estudantes envolvidos nas ações contestatórias passaram a se autodenominarem como "ocupas", o que esclarece a adesão e uso desse termo no decorrer do texto. 
estudantil, de acordo com ele: "A ideia que temos do movimento estudantil era daqueles jovens que iam às ruas, agora eles querem de forma espontânea permanecer na escola e discuti-la" (ROSA, 2016, s./p.). Portanto, verifica-se uma abertura do jornal e do jornalista em dialogar e ouvir os ocupas, bem como os seus apoiadores, estabelecendo uma informação mais ampla e que evidencia a participação ativa e os posicionamentos de alguns membros da ocupação.

\section{"AULAS DA LIBERDADE" E "ESTUDANTES NAS RUAS CONTRA REFORMA ESTUDANTIL": AS OCUPAÇÕES SOB A ÓTICA DO JORNAL DIÁRIO DA MANHÃ}

No dia 26 de outubro de 2016 foi publicada uma matéria no jornal Diário da Manhã, na coluna Cotidiano, com o título "Aulas da liberdade". A matéria aborda brevemente as ocupações de escolas, e apresenta o movimento como contrário ao governo "interventor" de Michel Temer (presidente da república em exercício em 2016) ao afirmar que o mesmo "enfrenta" uma revolta estudantil. O que evidencia ao leitor que as ações contestatórias a PEC 241/2016 e a MP 746 eram um ataque ao governo Temer, que estava realizando o papel de mediador político, ao mesmo tempo em que realizava ações necessárias no cenário nacional, enquanto estudantes revoltados se colocavam como opositores a tais ações.

O caráter educativo e reivindicativo das ocupações de escolas, infelizmente, não é abordado na matéria do Diário da Manhã, que também traz um balanço sobre as instituições ocupadas. O texto publicado não é assinado por nenhum jornalista ou colaborador do jornal, não traz nenhuma entrevista contundente com alunos ou professores, mas destaca trechos de uma entrevista realizada pelo G1 Goiás com um suposto aluno não identificado. Deste modo, percebe-se que a reportagem não cita dados para corroborar com o texto divulgado, os quais serviriam para conferir a veracidade dos fatos apresentados, dando um embasamento mais consistente diante das ideias desenvolvidas.

Durante as ocupações foi comum que os ocupas pedissem doações de alimentos e produtos de limpeza para continuarem nos prédios das instituições 
por eles ocupadas, o que também possibilitava que mais pessoas estivessem engajadas nas manifestações, apoiando as reinvindicações a partir dessas contribuições. Contudo, ao citar a necessidade dos ocupas receberem doações a matéria opta em afirmar que os manifestantes estavam buscando meios para continuarem "acampados", utilizando termos pejorativos para se referir às ocupações como meio de dissuadir o leitor do caráter reivindicativo e protestatório das ações.

A matéria em questão ainda enfatiza os "prejuízos" relacionados à realização do Enem, caso as escolas não sejam desocupadas até dia 31 (de outubro), enfatizando o valor defendido pela Advocacia Geral da União a ser cobrado dos manifestantes pelo custo da aplicação das provas. Outro "prejuízo" que as ocupações estariam causando, de acordo com a reportagem, é relacionado à realização das eleições municipais no país, pois as escolas eram adequadas para serem colégios eleitorais nos dias de votação. Ou seja, os estudantes não devem lutar por uma educação de qualidade, mas devem prestar o Enem, ou pelo menos não atrapalhar quem assim desejasse, mesmo que as Instituições de Ensino Superior que eles ingressem através do exame estejam/sejam sucateadas por parte das medidas condenadas no movimento das ocupações.

Além disso, os estudantes "revoltosos" e em situação de "acampamento", não possuem nenhum espaço para expor os seus posicionamentos na matéria, mas caso tenham 16 anos e título de eleitor em mãos, podem desocupar as escolas e ir exercer a cidadania através da escolha de seus representantes políticos junto ao restante da comunidade. Outro ponto que deve ser destacado é de que a matéria não aborda, especificamente, os prejuízos para os rumos da educação, não dá voz aos ocupas, nem os reconhece enquanto manifestantes politicamente capazes; mas em contrapartida traz, assim como em outras matérias, o andamento da votação da PEC no senado e diferentes opiniões de economistas sobre os acontecimentos.

$\mathrm{Na}$ outra matéria sobre o movimento de ocupação de escolas, também publicada pelo jornal Diário da Manhã, intitulada "Estudantes nas ruas contra 
reforma estudantil", a reportagem de Silva (2016) afirma que uma das principais mudanças propostas pela MP 746/2016 no currículo é sobre o direito do estudante escolher qual caminho seguir dentro da escola, e que ele não seria obrigado a estudar os mesmos currículos.

A escolha das palavras "direito" e "escolha", coloca em evidência o caráter contrário às ocupações, que traz de maneira implícita na reportagem que se os estudantes lutam contra um direto de escolha, eles não estão apenas abrindo mão do seu direito como também estão ferindo o direito de escolha de alguém. Além disso, ainda é destacado que o estudante não seria obrigado a estudar a mesma coisa que os outros, ou seja, expõe uma mensagem de que os ocupas estão querendo forçar os estudantes brasileiros a continuarem cursando matérias como sociologia e filosofia, que segundo a reportagem deixariam "de ter a atual importância quando são oferecidas para todos" (SILVA, 2016, s./p.).

O título da segunda seção da reportagem é "Fogo", fala sobre uma manifestação dos estudantes onde houve a queima de pneus, no entanto, a reportagem não traz dados sobre onde tal manifestação ocorreu, com quantos manifestantes contou; cita apenas que os manifestantes questionavam o então Governo do Estado de Goiás sobre a implantação das Organizações Sociais na educação.

A reportagem também traz a breve fala de uma estudante de direito chamada Juliana Aguiar, onde ela afirma que "querem vender tudo, criar um ninho de corrupção agora que estão vendo suas tramas caírem. Estão vendendo a Celg. Amanhã será a Saneago. E hoje são as nossas escolas" (SILVA, 2016, s./p.).

O assunto das OSs também é abordado pelos manifestantes pelo que o governo de Goiás havia anunciado um dia antes das manifestações, alegando que realizaria o repasse de 23 escolas estaduais para a iniciativa privada por meio da gestão de OSs, e que Grupo Transparência e Resgate Social (GTR) receberia cerca de 1 milhão de reais por mês para gerir as instituições de educação. 


\section{ESTUDANTES PROTESTAM CONTRA REFORMA DO ENSINO MÉDIO E A PEC 241 EM GO}

A reportagem do G1 GO, publicada na noite do dia 18 de outubro de 2016, foi sucinta e relatou de forma breve que "Estudantes protestam contra reforma do ensino médio e a PEC 241 em GO". Foi descrito o trajeto realizado pelos manifestantes, partindo da Praça Universitária e seguindo em direção a BR-153, na altura do viaduto da Avenida Anhanguera, retornando para a praça de origem onde o ato foi encerrado. Foi mencionado que houve o policiamento do ato por parte da Polícia Rodoviária Federal (PRF) e Polícia Militar (PM), além de relatar que o IFG em Anápolis havia sido ocupado pelos estudantes contra a PEC 241 e a MP 746.

\section{O ENEM E AS OCUPAÇÕES EM 2016: UMA LEITURA DAS REPORTAGENS PUBLICADAS NO JORNAL OPÇÃO}

O Jornal Opção publicou no dia 03 de novembro uma matéria cujo título foi "Enem pode ser adiado em mais escolas. Inep divulga nova data na sexta-feira (4)". Como o título diz, a matéria tem como foco a questão do adiamento do Enem, ainda destaca o número de 304 escolas que tiveram o exame cancelado e enfatiza que em Goiás isso ocorreu em sete escolas, e que 4.113 estudantes goianos serão afetados pelo adiamento (DAMASCENO, 2016).

A matéria também destaca o pedido dos estudantes que estavam participando das ocupações para que houvesse a transferência de local, não o adiamento, assim como ocorreu com o segundo turno das eleições municipais pelos Tribunais Regionais Eleitorais. A resposta aos pedidos de deslocamento das provas foi dada pela então presidente do Inep (Instituto Nacional de Estudos e Pesquisas Educacionais Anísio Teixeira), Maria Inês Fini, em uma coletiva de imprensa, onde ela disse que: "Foi muito volátil esse movimento. Ora [os locais] estavam ocupados, ora desocupados, mudou muito. Não há possibilidade de alocarmos o novo local de prova" (DAMASCENO, 2016, s./p.). 
Além disso, a reportagem também traz uma nota com informações da Agência Brasil em que o Inep havia afirmado que mesmo que as escolas fossem desocupadas até o dia 04/11, um dia antes do Enem, as provas não seriam aplicadas nesses locais, pois o prazo estabelecido para a desocupação era até 31/10. E reforça, que se caso mais locais fossem ocupados, a aplicação de provas neles também seria adiada para os dias 03 e 04 de dezembro (DAMASCENO, 2016).

No dia seguinte, 04 de novembro de 2016, foi publicada na coluna "Educação" do Jornal Opção outra reportagem, assinada por Larissa Quixabeira, com o título "Enem será adiado para 240 mil candidatos por causa de ocupações das escolas". Como o título elucida, a reportagem fala sobre o adiamento do Enem e culpa as ocupações por isso, traz o número de 364 locais onde as provas foram adiadas e de 240.304 candidatos que prestaram o exame em outra data (QUIXABEIRA, 2016).

A autora da matéria ainda destaca que houve uma primeira lista realizada pelo Inep, mas que após isso, mais escolas foram ocupadas. A matéria trata brevemente que as ocupações, em diversos estados do Brasil, estão sendo realizadas por estudantes do Ensino Médio, Superior e Educação Profissional, como forma de pressionar o governo por meio de ocupações de escolas; não apresenta nenhuma entrevista com os ocupas.

\section{CONSIDERAÇÕES FINAIS}

Os movimentos sociais, especialmente o movimento estudantil no qual as ocupações estudantis estão atreladas, assumiram um papel fundamental no processo de lutas pelos direitos da educação básica, se opondo e expondo em detrimento de medidas e projetos construídos para o avanço de ofensivas de uma agenda conservadora e marcada por retrocessos. Trata-se da expressão política juvenil de sujeitos jovens, tanto da Educação Básica, Ensino Técnico ou Superior, em prol de bens comuns, para a manutenção e ampliação do sistema educacional brasileiro, não de sua dissolução. 
Os movimentos sociais atuam e possuem um caráter formativo, desde a sua concepção. São grupos que se reúnem e buscam, de maneira ordenada, promoverem medidas que deem visibilidade a causas sociais e de impacto abrangente; muitas vezes desconhecidas pela sociedade em geral. São jovens, que em sua maioria, passam a atuar na linha de frente desses movimentos, demonstrando o seu ativismo, suas ideologias e capacidade de dialogar com diferentes frentes de poder, buscando estabelecer medidas que primem pelo bem coletivo. Portanto, são ações que preparam esses sujeitos, não só para uma atuação coletiva, mas também individual, por desenvolver e aguçar o senso crítico, de pertencimento, a responsabilidade e a capacidade de se expressar e ouvir o outro; fatores fundamentais para a formação pessoal e que infunde no coletivo.

Ademais, é preciso destacar o papel que a mídia exerce, de maneira específica, as matérias jornalísticas, elemento central de análise da presente discussão. As ocupações estudantis foram divulgadas de maneiras distintas, a depender do jornal e de suas perspectivas, assim como a dos próprios jornalistas, Ora foram de fato divulgadas e retratadas em sua dimensão plural, como um movimento estruturado, com objetivos e fins específicos; ora foram descaracterizadas, primando por uma defesa de forças governamentais, seja a nível estadual ou federal, e colocando os ocupas como figuras disruptivas da sociedade, que atuam na contramão a partir de atitudes "revoltosas", implantando "acampamentos" e provocando "prejuízos".

Os ocupas, no limiar dos movimentos sociais, assumiram uma posição de enfrentamento ao conservadorismo dominante das instituições estaduais e federais, desenvolveram autonomia e se beneficiaram da vivência de espaços formais e não formais de aprendizagem, isso tudo em um contexto de mudanças nacionais, seja na política ou nos paradigmas da sociedade brasileira. Os jovens e o movimento estudantil, em geral, demonstraram a sua capacidade de lutar por aquilo que acreditam e que infunde em estâncias maiores, impactando todo o meio social. As ocupações estudantis a nível nacional e estadual foram importantes, por questionarem as estruturas dominantes do poder e lutaram pelos direitos sociais. 


\section{REFERENCIAS}

ARROYO, Miguel González. Pedagogias em movimento - o que temos a aprender dos Movimentos Sociais? Currículo sem Fronteiras, s./l., v.3, n.1, p. 28-49, jan./jun., 2003. Disponível em: https://www.curriculosemfronteiras.org/vol3iss1articles/arroyo.pdf. Acesso em: 12 mar. 2021.

AULAS da liberdade. Diário da manhã, Goiânia, s./p., 26 out. 2016. Disponível em: https://www.dm.com.br/cotidiano/2016/10/aulas-da-liberdade/. Acesso em: 24 fev. 2021.

BRASIL. Emenda Constitucional $n^{\circ}$ 95, de 15 de dezembro de 2016. Altera o Ato das Disposições Constitucionais Transitórias, para instituir o Novo Regime Fiscal, e dá outras providências. Presidência da República, Secretaria Geral, Subchefia para Assuntos Jurídicos, Brasília, 2016b. Disponível em: http://www. planalto.gov.br/ccivil_03/constituicao/emendas/emc/emc95.htm. Acesso em: 10 out. 2021.

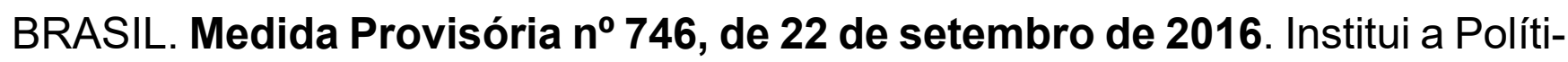
ca de Fomento à Implementação de Escolas de Ensino Médio em Tempo Integral, altera a Lei $n^{\circ} 9.394$, de 20 de dezembro de 1996, que estabelece as diretrizes e bases da educação nacional, e a Lei n ${ }^{\circ} 11.494$ de 20 de junho 2007, que regulamenta o Fundo de Manutenção e Desenvolvimento da Educação Básica e de Valorização dos Profissionais da Educação, e dá outras providências. Presidência da República, Secretaria Geral, Subchefia para Assuntos Jurídicos, Brasília, 2016a. Disponível em: http://www.planalto.gov.br/ccivil_03/_ato2015-2018/2016/ mpv/mpv746.htm. Acesso em: 10 out. 2021.

CASSAB, Clarice. Contribuição á construção das categorias jovem e juventude: uma introdução. Locus: revista de História, Juiz de Fora, v. 17, n. 2, p. 145-159, jul./dez., 2011. Disponível em: https://periodicos.ufjf.br/index.php/locus/article/ view/20352. Acesso em: 10 jul. 2020.

COMO ocupar um colégio? Manual escrito por estudantes secundaristas da Argentina e Chile. 0 mal-educado: luta e organização nas escolas, s./p., 21 out. 2015. Disponível em: https://gremiolivre.wordpress.com/2015/10/21/como-ocupar-um-colegio-versao-online/. Acesso em: 9 set. 2021.

DAMASCENO, Amanda. Enem pode ser adiado em mais escolas. Inep divulga nova lista na sexta-feira (4). Jornal Opção, Goiânia, s./p., 3 nov. 2016. Disponível em: https://www.jornalopcao.com.br/ultimas-noticias/enem-pode-ser-adiado-em-mais-escolas-inep-divulga-nova-lista-na-sexta-feira-4-79233/. Acesso em: 24 fev. 2021. 
DAYRELL, Juarez. O jovem como um sujeito social. Revista Brasileira de Educação, Rio de Janeiro, s./v., n. 24, p. 40-52, set./dez., 2003. Disponível em: http://www.scielo.br/pdf/rbedu/n24/n24a04. Acesso em: 12 set. 2020.

ELIAS, Norbert. A sociedade dos indivíduos. Organizado por Michael Schroter e Traduzido por Vera Ribeiro. Rio de Janeiro: Zahar, 1994.

ESTUDANTES protestam contra reforma do ensino média e a PeC 241 em GO. G1 GO, Goiânia, s./p., 18 out. 2016. Disponível em: http://g1.globo.com/goias/ noticia/2016/10/estudantes-protestam-contra-reforma -do-ensino-medio -e-pec-241-em-go.html?fbclid=IwAR2L77qUivVNHieRdt0BBSkcKymBRxK_Fs5yhJMj4LtnKprEKwu9F2_myjU . Acesso em: 10 jun. 2021.

GROPPO, Luís Antonio. O novo ciclo de ações coletivas juvenis no Brasil. In: COSTA, Adriana Alves Fernandes; GROPPO, Luís Antonio (orgs.). 0 movimento de ocupações estudantis no Brasil. São Carlos: Pedro e João Editores, 2018, p. 85-118.

LUCENA, Hadassa Monteiro de Albuquerque; CARAMELO, João Carlos Pereira; SILVA, Severino Bezerra da. Educação popular e juventude: o movimento social como espaço educativo. Cadernos de Pesquisa: São Paulo, v. 49, n. 174, p. 290-315, out./dez., 2019. https://doi.org/10.1590/198053146754. Disponível em: https://www.scielo.br/j/cp/a/7pytLbHGx7wGnSYMsJ4JYzn/abstract/?lang=pt. Acesso em: 4 mar. 2021.

PEIXOTO, Maria Angélica. Formação e movimento estudantil. Revista Movimentos Sociais, Goiânia, v.1, n. 1, p. 161-182, 2016.

PESAVENTO, Sandra Jatahy. Cultura e representações, uma trajetória. Anos 90: revista do Programa de Pós-Graduação em História, Porto Alegre, v. 13, n. 23/24, p. 45-58, jan./dez., 2006. https://doi.org/10.22456/1983-201X.6395. Disponível em: https://seer.ufrgs.br/anos90/article/view/6395. Acesso em: 8 jun. 2021.

QUIXABEIRA, Larissa. Enem será adiado para 240 mil candidatos por causa de ocupações de escolas. Jornal Opção, Goiânia, s./p., 4 nov. 2016. Disponível em: https://www.jornalopcao.com.br/ultimas-noticias/enem-sera-adiado-para-240-mil-candidatos-por-causa-de-ocupacoes-de-escolas-79280/. Acesso em: 24 fev. 2021. 
ROSA, Luiz Eduardo. O dia a dia da ocupação no Instituto Federal de Goiás. Jornal Estado de Goiás, Anápolis, s./p., 14 nov. 2016. Disponível em: https:// www.jornalestadodegoias.com.br/2016/11/14/o-dia-a-dia-da-ocupacao-no-instituto-federal-de-goias/. Acesso em: 26 abr. 2021.

SILVA, Welliton Carlos da. Estudantes nas ruas contra reforma estudantil. Diário da manhã, Goiânia, s./p., 19 out. 2016. Disponível em: https://www.dm.com.br/ politica/2016/10/estudantes-nas-ruas-contra-reforma-estudantil/. Acesso em: 22 de maio de 2021. 
dol 10.48209/978-65-JUV12-40-1

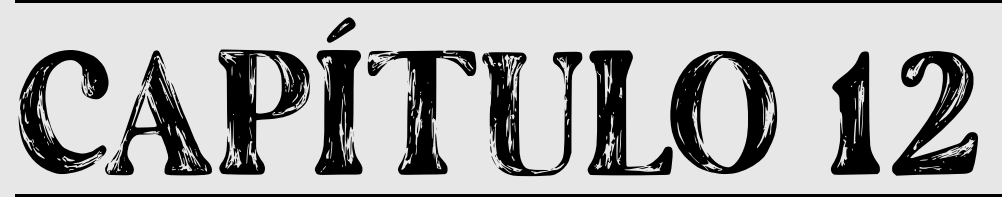

\section{A PARTICIPAÇÃO DOS JOVENS POR MEIO DA MÚSICA SERTANEJA NA FOLIA DE SANTOS REIS EM ANÁPOLIS, GOIÁS}

Mirelle Antônia Souza Freitas Ademir Luiz da Silva 


\section{INTRODUÇÃO}

Os festejos da Folia de Reis carregam o estigma de serem considerados anacrônicos e voltados apenas aos mais velhos. Nada mais longe da verdade. A juventude marca forte presença nestes eventos, sendo algumas vezes seus protagonistas e força motriz.

A Folia de Santos Reis é um festejo religioso, popular e tradicional que remonta a passagem bíblica dos três Reis Magos em visita ao nascimento do menino Jesus. Costuma ocorrer entre 24 de dezembro a 6 de janeiro. $\mathrm{Na}$ atualidade, tal festejo acontece em várias regiões interioranas do estado de Goiás. Uma de suas particularidades está na participação do jovem, na introdução de novos instrumentos eletrônicos e nas canções executadas após as ritualidades religiosas que variam em cada festejo. Esses momentos são tidos como o descanso após o almoço e o último dia da festa, que costuma abranger uma quantidade significativa de pessoas. A presença desse público na festividade religiosa é de suma importância, pois são eles que darão continuidade, com o passar dos anos, a realização da Folia de Santos Reis.

Uma das marcas da Folia de Reis é de ser passada de geração para geração. Os jovens buscam de alguma forma integrarem-se nesse espaço, seja para tocar, cantar ou se divertir na parte profana das atividades. Andrade (2008) pesquisou acerca da identidade religiosa dos jovens, retratando experiências vivenciadas no contexto religioso e social da festa, afirmando que:

Os jovens trazem em sua história de vida, a experiência religiosa que os seus pais favoreceram desde criança. Essas experiências foram marcadas pela dimensão sentimental, vivida por momentos fortes como enfermidades, mortes, solidão, amizades, namoro... Algumas são experiências místicas que estão ligadas ao tipo de personalidade dos jovens, dentro do contexto sócio-político e cultural de cada grupo social. A experiencia que o indivíduo traz na sua história é formada a partir da interpretação de várias vivências, são múltiplos conhecimentos que constituem a experiencia de vida de cada um (BERGER; LUCKMANN, 2004, p. 16 apud ANDRADE, 2008, p. 41). 
Essas experiências são construídas desde a infância, sendo o grupo familiar o principal incentivador desses jovens, levando-os a atuar no cenário religioso da comunidade em que estão inseridos. No caso especifico da Folia de Santos Reis, normalmente os pais procuram levar os filhos desde pequenos e isso desperta sentimentos que são levados para o futuro. E faz com que os jovens participem de forma assídua do festejo, tanto nos momentos ritualísticos em que há a cantoria, a benção das casas durante o giro e o agradecimento dos altares, como também naqueles instantes de diversão que acontecem após a parte religiosa que são embalados por músicas sertanejas, danças, conversas, venda de alimentos entre outros.

É importante destacar que:

Pertencer a determinada faixa etária - e a juventude de modo particular - representa para cada indivíduo uma condição provisória. Mais apropriadamente, os indivíduos não pertencem a grupos etários, eles os atravessam. É justamente o caráter essencial de liminaridade, típica da juventude, conjugada com a maior ou menor brevidade da passagem pela condição de jovem, que caracteriza em última análise (porém, de maneira diversa nas diferentes sociedades) a juventude, determinando tantos as atitudes sociais, a atitude dos "outros" no seu confronto, quanto a visão que os jovens têm de si mesmos (LEVI; SCHMITT, 1996, p. 9, grifo do autor).

Portanto, após esses anos de introdução, os jovens tendem a assumir cada vez mais responsabilidades dentro do espaço hierárquico da festa, muitas vezes substituindo os pais, iniciando um novo ciclo.

Groppo (2000) ao analisar os grupos juvenis, destaca o "lazer" sendo a prática comum entre os jovens. Conforme o autor, o "lazer tornou-se um espaço e um tempo cada vez mais reconhecido pela sociedade e cada vez mais importante para os hábitos contemporâneos de consumo" (GROPPO, 2000, p. 52). Tal prática também pode ser evidenciada no festejo religioso, uma vez que esse público aproveita a festa para reunir-se com os amigos, consumir alimentos, bebidas alcoólicas e eventualmente drogas, além paquerar e dançar, aproveitando a sociabilidade gerada pelo rito para realizar atividades sociais de caráter secular. 
É comum que os participantes que tocam algum instrumento, nesses instantes, busquem executar músicas sertanejas que fazem sucesso na voz de duplas conhecidas nesse meio. Digno de nota que não descartam a música sertaneja raiz. Dessa forma, a prática da Folia de Santos Reis engloba variadas características e a atuação dos jovens nesse espaço é significativa, já que a tradição de comemorar esse festejo permanecerá viva na memória e tende a ser continuada por esse público.

A proposta central deste trabalho é realçar de que forma os jovens foliões contribuem com a realização da Folia de Santos Reis, analisando de modo destacado qual tipo de músicas são tocadas nos momentos de descanso. $\mathrm{Na}$ primeira seção será demonstrado o contexto histórico das músicas tocadas pelos jovens foliões. Logo em seguida, analisaremos as principais canções executadas durante a Folia de Santos Reis examinada em nosso trabalho de campo. A delimitação temporal remonta ao final do ano de 2017 e início de 2018, na cidade de Anápolis, interior do estado de Goiás.

O artigo contou com a revisão bibliográfica, a partir da leitura de livros, teses, dissertações e artigos. A análise recorreu à temática da festa de cunho religioso popular e procurou destacar o papel dos jovens no cenário religioso e secular de tais eventos. Nessa perspectiva, foram avaliados aspectos como a manutenção da tradição, o espaço do sagrado e do profano que fortalece a relação entre os partícipes.

No que diz respeito a festividade religiosa, entre os autores consultados destacou-se Brandão (2004), que realizou um estudo minucioso acerca da Folia de Santos Reis goiana, os rituais que permeiam tal festividade, sejam eles sagrados ou profanos. Outra referência é D'Abadia (2014), que discorreu sobre as festas dedicadas aos santos padroeiros, analisando aspectos como o catolicismo popular, o momento de lazer, as ritualidades sagradas e a construção da identidade religiosa.

No que concerne a importância dos jovens no contexto religioso, os autores utilizados foram Duque (2007), que buscou retratar no distrito de Braga a relação 
social e religiosa que o jovem adquiriu frente a organização da Igreja Católica. Assim como esse autor, Sofiati (2009) atribuiu destaque especial para as práticas religiosas da juventude carismática, fazendo observações no contexto histórico geral da renovação carismática e de que forma tal movimento proporcionou mudanças na vivência desses jovens. Já Andrade (2008) ressaltou a identidade religiosa juvenil, realizando entrevistas com um pequeno grupo de jovens do ensino médio na faixa etária entre 15 e 19 anos, abordando questões envolvendo o sagrado, a identidade e a religião.

Em relação ao contexto das músicas sertanejas, optamos por usar a autobiografia atribuída a dupla de cantores sertanejos Fernando \& Sorocaba (2017), considerando a grande penetração que eles possuem entre a população pesquisada. A dupla ajudou a impulsionar o chamado "sertanejo universitário" como um dos estilos musicais mais consumido pelo público jovem no Brasil. Também são empresários, gerenciando outros artistas do ramo sertanejo.

Angelo (2012) efetuou um estudo minucioso acerca das gerações que a música sertaneja percorreu até chegar à atualidade. Fez a seguinte reflexão: as músicas que foram compostas nas décadas de 1930 até 1960 não sofreram alterações em suas letras e por isso fazem parte da cultura de massa, sendo constantemente regravadas por vários artistas que modificam apenas o arranjo musical, mantendo a melodia, o ritmo e a harmonia da música. Os temas mais recorrentes são apologias à vida no campo, histórias de amor trágicas e narrativas que exaltam a honestidade, valentia ou ombridade do homem do campo.

Em se tratando das músicas atuais, os cantores e duplas sertanejas procuram descrever em suas canções temas sobre o "cotidiano das pessoas", "baladas", "festas" e "pegação". Com as inovações tecnológicas, as plataformas musicais contribuíram bastante para que essas músicas fossem consumidas e caíssem no gosto de parte da população. Alonso (2011) em seus estudos sobre a modernização da música sertaneja rural, traçou uma discussão acerca desse estilo e realçou a divisão entre a música sertaneja e a música caipira, a partir de alguns discursos que foram legitimadores nas décadas de 1960 até 1990. 


\section{A MOdERNa MÚSICA SERTANEJA ENTRE OS JOVENS FOLIÕES}

Identificamos que os jovens foliões que participam da Folia de Santos Reis em Anápolis são responsáveis por tocar instrumentos como caixa, pandeiro e sanfona. Quando reúnem-se com os demais foliões, nos intervalos do rito, costumam tocar músicas no estilo sertanejo universitário. Porém, aparentemente, isso não influencia no respeito que eles têm pela música sertaneja raiz, já que tal repertório faz parte da vivência dos familiares.

Sobre o parentesco, normalmente são filhos e netos dos antigos foliões. São jovens que nasceram no final do século $X X$ e início do $X X I$, que cresceram escutando artistas de forte presença na indústria cultural, tais como: Michel Teló, Jads \& Jadson, Fernando \& Sorocaba, Bruno \& Barreto, Matheus \& Kauan e Luan Santana. O termo "sertanejo universitário", atribuído à essa vertente da música sertaneja, foi cunhado a partir de 2005. Segundo Alonso (2011), tal ritmo passou por uma institucionalização social devido aos processos culturais complexos proporcionados pela nova geração de artistas. Para ele,

É preciso lembrar que a partir de 2005 esse processo se acelerou devido ao surgimento do chamado "sertanejo universitário", fazendo com que os sertanejos da década de 90 ficassem datados e aos mesmos tempos fossem vistos como parte de uma tradição antiga para os jovens "universitários". De qualquer forma, a própria noção de se chegar à universidade, já denota uma determinada institucionalização (ALONSO, 2011, p. 379, grifo do autor).

Portanto, o termo "sertanejo universitário" implica em uma pretensão de atualização da música realizada na década de 1990, ela mesmo já amplamente afastada da estética raiz. O cantor Sorocaba, em sua autobiografia, salienta que iniciou sua carreira ainda no período em que estava na universidade. Encontrou naquele local a oportunidade de tocar e cantar dentro da própria instituição e em barzinhos próximos. Esses pequenos shows amadores foram importantes em sua carreira musical. 
Logo no início da faculdade, comecei a tocar em festas de amigos de curso. Eu tinha um kit de som bem simples, então chegava ao churrasco da agronomia, da zootecnia ou da veterinária, plugava meu violão e um microfone num amplificador e saía cantando. Eu não precisava de grana, já que a faculdade era pública e meu pai mandava dinheiro todo mês, mas esses churrascos rendiam uns duzentos, trezentos reais por apresentação. Eu nunca tocava de graça. Reinvesti boa parte desse dinheiro na música, e acho que esse foi um dos segredos do meu futuro sucesso (FERNANDO \& SOROCABA, p. 60).

Além do Fernando \& Sorocaba, outras duplas iniciaram as suas carreiras em universidades, como foi o caso do João Bosco \& Vinícius, João Neto \& Frederico, entre outros.

A atual música sertaneja retrata questões do cotidiano, já que os artistas sertanejos têm por objetivo destacar em suas letras comportamentos vivenciados pela população que reside na "área urbana". Como exemplo, o "relacionamento amoroso", a "traição", a "saudade", a "balada", a "diversão", as formas de superação que encontram ao terminar um relacionamento amoroso. Tudo da maneira mais simples possível, privilegiando o prosaico em detrimento do estético, de modo a agradar ao público médio e, principalmente, a "indústria cultural" que lucra com a reprodução dessas músicas.

Entre as características que podemos distinguir entre a moderna música sertaneja e a música raiz está a introdução dos instrumentos tecnológicos, as letras das canções que passaram por várias ressignificações e o público alvo que pretendem atingir, principalmente os jovens desses mesmos centros urbanos. As referências básicas de seu "modo de vida" são, normalmente, bastante identificáveis visualmente e costumam se remeter a culturas estrangeiras. É fato que,

subcultura adolescente que era considerada agressiva incluía o rock and roll, o uso de carros cujo motor fora envenenado e a carroceria modificada de modo a personalizá-la, o corte de cabelo à Presley ou cabelos longos, a roupa retomando estilos afro-americanos, as gangues (LEVI; SCHMITT, 1996, p. 361).

Essa estética rocker tem sido usada com cada vez mais intensidade entre os artistas reconhecidos como "sertanejos" desde a década de 1970, tendo como 
pioneiros nomes Leo Canhoto \& Robertinho, que introduziram a guitarra elétrica, Milionário \& José Rico e Christian \& Ralf.

Os jovens atuantes na Folia de Santos Reis, apesar de tocarem e cantarem o sertanejo raiz, também tocam e cantam músicas relacionadas ao sertanejo universitário, pois a folia abrange tanto os antigos foliões como os jovens, por isso que o sertanejo universitário é bem-vindo entre esses.

$\mathrm{Na}$ ilustração 1 registra um momento de descanso entre os jovens foliões de Anápolis.

Ilustração 1: foliões em momento de descanso

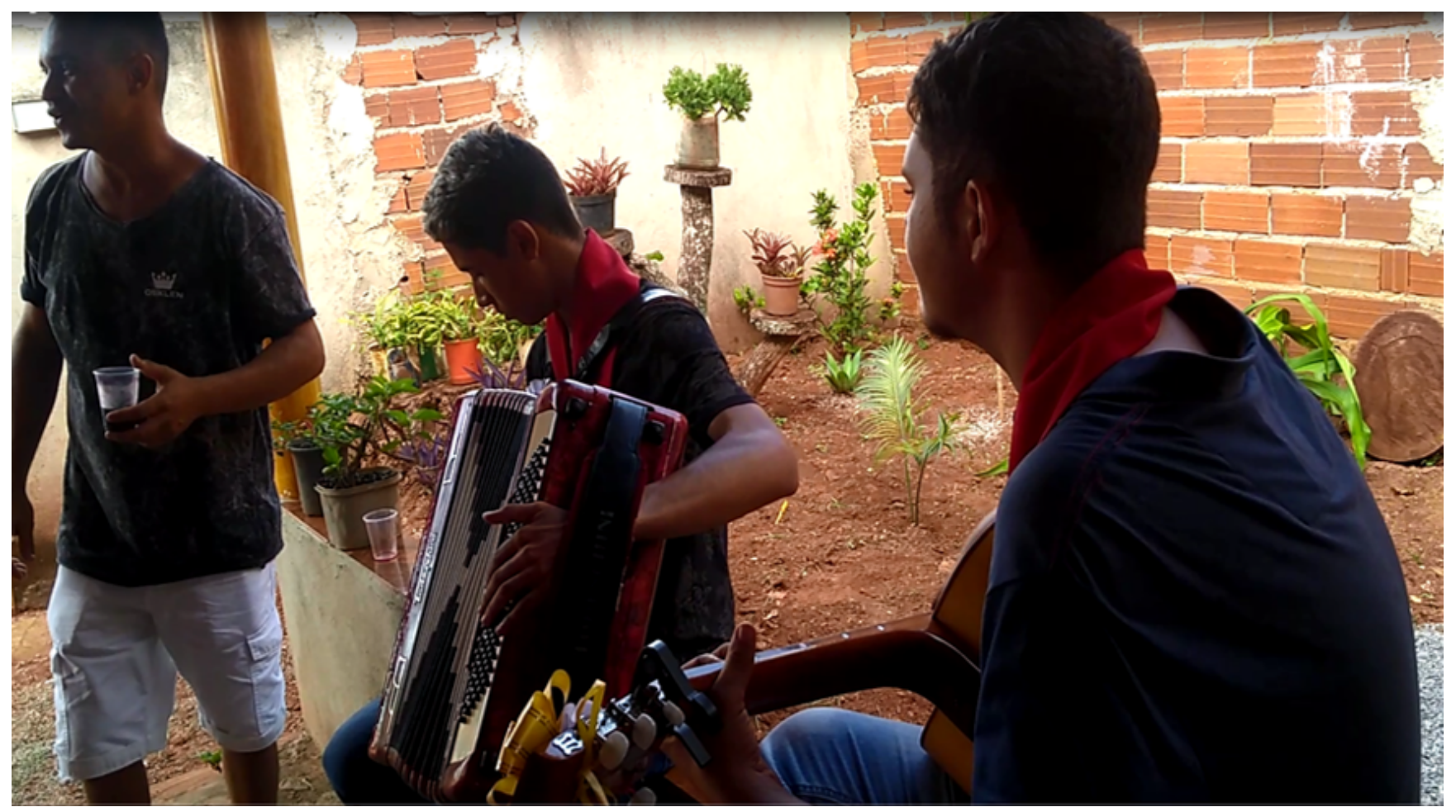

Fonte: Freitas, Dez/2017.

Estão com uma sanfona e um violão. Cantaram e tocaram músicas do repertório de duplas e cantores que faziam sucesso no período do registro fotográfico, tais como Henrique \& Juliano, Matheus \& Kauan, Jefferson Moraes entre outros. Porém, quando os antigos foliões começaram a tocar as "modas de viola", os jovens imediatamente deixaram de tocar as músicas sertanejas atuais para cantar e tocar o "sertanejo raiz". Com essa cena, constatou-se que os jovens 
apesar de recorrerem ao sertanejo universitário, respeitam a música caipira que para eles é um gênero considerado tradicional e que deve ser preservado.

\section{CANÇÕES EXECUTADAS NOS MOMENTOS DE DESCANSO DA FOLIA DE SANTOS REIS}

A produção artística de uma geração representa sua visão de mundo, de acordo com os autores,

A juventude está naquele centro onde nasce o novo", escreveu Walter Benjamin, em 1914, e logo depois acrescentava: "Há novamente uma geração que deseja superar a encruzilhada, mas a encruzilhada não está em nenhum lugar". Hoje podemos acrescentar que uma fase da metafísica da juventude em que estava imenso o próprio Benjamin, mesmo olhando mais adiante, esgotou-se. (...) Não existe uma juventude na encruzilhada, nem, como havia intuído Benjamin, se vislumbra em nenhum lugar uma encruzilhada definida, ao passo que o centro também se volatizou: o novo parece afastar-se rumo a um futuro distante ou mergulhar em aspectos ignorados do social ou difundir-se na diáspora das migrações e das culturas. Portanto, temos razões para fazer uma história das metafísicas da juventude e, tendo aliviado está última de seu peso, uma história da condição juvenil (LEVI; SCHMITT, 1996, p. 373 - 374, grifo do autor).

Um espaço privilegiado para identificar essas problemáticas são as letras das músicas produzidas e consumidas pela juventude.

As canções mais tocadas pelos jovens na Folia de Reis no final de 2017 e início de 2018 eram músicas que faziam sucesso popular nas rádios e na internet, demonstrando que a população estudada pode ser considerada como consumidores regulares dos produtos da indústria cultural. As mais tocadas foram; vidinha de balada de Henrique \& Juliano, Um centímetro de Jefferson Moraes e Amor assim de Matheus \& Kauan. Verifica-se que eles recorreram há uma música com caráter dançante e duas que tratam do amor romântico A canção vidinha de balada foi gravada pela dupla sertaneja Henrique \& Juliano no ano de 2017, faz parte do DVD "O céu explica tudo" e foi composta por Diego Silveira. Abaixo a letra da canção: 
Vidinha de balada

(comp. Diego Silveira- ano:2017)

Oi, tudo bem?

Que bom te ver

A gente ficou, coração gostou

Não deu pra esquecer

Desculpa a visita

Eu só vim te falar

Tô a fim de você

E se não tiver, cê vai ter que ficar

Eu vim acabar com essa sua vidinha de balada

E dar outro gosto pra essa sua boca de ressaca

Vai namorar comigo, sim!

Vai por mim, igual nós dois não tem

Se reclamar, cê vai casar também

Com comunhão de bens

Seu coração é meu e o meu é seu também

Vai namorar comigo, sim!

Vai por mim, igual nós dois não tem

Se reclamar, cê vai casar também

Com comunhão de bens

Seu coração é meu e o meu é seu também

Vai namorar comigo, sim!

Fonte: https://www.letras.mus.br/henrique-e-juliano/vidinha-de-balada/. Acesso em: 10 de nov. de 2018.

A proposta dos referidos artistas é dialogar com o público por meio de um registro cotidiano, pois as músicas fazem referência a uma conversa informal nas redes sociais, facilitando aos ouvintes a assimilação frente aos trechos: Vai namorar comigo, sim!/ vai por mim, igual nós dois não tem / se reclamar, cê vai casar também/ com comunhão de bens/ seu coração é meu e o meu é seu também/ vai namorar comigo, sim!. A intenção é de que as letras entrem no gosto popular, conforme Angelo (2012), ao falar sobre as características dessas canções afirma 
que:

Outra mudança notória é a busca pelas letras simples, nas quais o principal objetivo é fixar, para que as pessoas tenham facilidade em decorar e conseguinte cair no gosto popular. Versos simples e refrão repetitivos são a marca dessas novas canções (ANGELO, 2012, p. 9).

A partir da fala do autor nota-se que esses músicos contemporâneos privilegiam versos que fazem parte do cotidiano, e que dificilmente as pessoas esquecerão. Tendo em vista que o intérprete retrata nesta música uma pessoa que não quer ter um relacionamento sério, e por isso vive essa "vidinha de balada". Com isso é reverenciada entre os jovens, dado que retrata algo que ocorre com frequência nas relações atuais, cada vez menos estáveis. Fundamental perceber que essa instabilidade não é interpretada com tom de crítica, sendo considerado um valor social por si só.

A despeito disso, ao fazer uma comparação entre as músicas tocadas nos momentos de descanso pelos foliões idosos e os jovens foliões, conclui-se que o "amor romântico" é um elemento predominante em ambas às gerações musicais. Entretanto, verifica-se que as composições sofreram modificações na escrita. Em comparação a letra da música Moreninha Linda, de Tonico e Tinoco, e Vidinha de Balada, de Henrique \& Juliano, é perceptível essa alteração. Catelan (1989) na década de 1980, percebeu essas modificações nas composições, afirmando que a linguagem da música sertaneja é "pobre", pois era influenciada pelos desequilíbrios da zona urbana. Também a temática remontava o "amor", porém de maneira superficial, como foi o caso da canção Moreninha Linda.

Outra particularidade que é próprio do sertanejo universitário, diz respeito às duplas que só cantam em dueto a partir do refrão, diferentemente da música caipira raiz que os artistas cantavam em dueto ao longo da música. Além disso, os cantores da moderna música sertaneja têm a preocupação em atrair todos os tipos de público, seja por meio do romantismo ou pelo caráter dançante. Fernando \& Sorocaba (2017) ao mencionar sobre essa nova geração na qual eles se enquadram, sustentam que: 
Nossa geração aproveitou aquele sopro de novidade e provocou uma revolução no mercado. Cada um teve sua contribuição. Nossa dupla, especificamente, mudou a sonoridade, incluindo elementos como a guitarra country, e deixou o ritmo mais dançante. Assim, vimos o sertanejo se tornar um ritmo de balada, ouvido não apenas quando as pessoas estavam sofrendo. Aproximamos o gênero de um novo público, adaptando a sua linguagem para alcançar uma geração mais jovem e urbana, mas que ainda preservava os valores do campo e tinha uma ligação com o estilo de vida dos caubóis. Essa galera não quer passar a noite em casa chorando depois de tomar um pé na bunda (FERNANDO \& SOROCABA, 2017, p. 240-242).

Como foi sublinhado pelos autores, a música sertaneja não é vista apenas como a "dor de cotovelo". Tal ritmo também possui características de músicas dançantes, o que leva as pessoas a consumirem esse produto em diferentes momentos e ambientes festivos.

Outra música tocada pelos jovens foliões foi do cantor Jefferson Moraes, que passou a fazer sucesso com o repertório das canções românticas e melodramáticas. Dentre as músicas desse artista, os jovens foliões cantaram e tocaram Um Centímetro, que foi gravada por Jefferson Moraes e tem como compositores: Ivo Mozart, Lucas Santos e Rafael Torres, tendo sido lançada em 2017. Abaixo a letra da canção:

Um Centímetro

(comp. Ivo Mozart, Lucas Santos e Rafael Torres- ano:2017)

Vamos por partes

Te falo o meu nome e você o seu

Que prazer te conhecer

Me fala mais de você, o que prefere fazer?

Balada ou parque, você escolhe

E eu vou lá, eu vou lá

Te dar um beijo e um abraço

Eu vou lá, eu vou lá

Que vamos ocupar o mesmo espaço 
E vai chegando perto de mim

E quando faltar um centímetro

Fecha os olhos e deixa rolar, deixa

Deixa o beijo durar, deixa

Deixa rolar, deixa, deixa o beijo durar

Fonte: https://m.letras.mus.br/ jefferson-moraes/um-centimetro/ Acesso em: 10 de nov. de 2018.

A canção procura causar emoção entre as "pessoas apaixonadas", utilizando jargão melodramático, como demonstra o trecho: e vai chegando perto de mim/e quando falta um centímetro/ fecha os olhos e deixa rolar, deixa/ deixa o beijo durar, deixa/ deixa rolar, deixa, deixa o beijo durar.

Os jovens ao reproduzir essa música utilizaram a sanfona e a viola. Apenas um cantava. É interessante pontuar que tinham um público considerável entre os jovens da comunidade que assistiam a apresentação.

Fernando \& Sorocaba (2017) destaca a importância do público,

Apresenta um desafio ainda maior: você pode seguir todos os passosplanejar, estabelecer metas, ter um bom produto, fazer a divulgação correta, estar em todas as rádios, ir aos programas de tv, investir na presença digital, criar um bom perfil nas redes sociais-, mas, ainda assim, quem determina o sucesso é o público. Se ninguém comprar seu disco, pedir a música na rádio ou ouvir no streaming, já era. Investir em artista é muito arriscado. O gosto do público é muito subjetivo e difícil de prever (FERNANDO\& SOCORABA, 2017, p. 222-223).

Como foi citado pelos autores, é de suma importância analisar a preferência do público em relação ao conteúdo das músicas, do ritmo e até mesmo a performance nos clipes, aspecto audiovisual da indústria cultural. A referida dupla sertaneja (Fernando \& Sorocaba), são empresários de vários cantores e duplas sertanejas, como: Luan Santana, Lucas Lucco, Marcos \& Belutti, entre outros. Eles responsabilizaram-se por cada um desses artistas, como os repertórios, a forma de divulgação das músicas e a temática. Porém, o sucesso desses artistas depende do público que vão consumir a música, tanto por meio das plataformas digitais como na compra de CD ou DVD. 
A última canção reproduzida pelos jovens da ilustração 1 compartilha das mesmas características da música analisada anteriormente. Cantaram e tocaram a música Amor Assim, de Matheus \& kauan, que faz parte do DVD "Na Praia 2", lançada em 2016. Uma observação que precisa ser ressaltada diz respeito às duas composições averiguadas, ambas são românticas, porém a canção de Matheus e Kauan realça uma traição perdoada. Os compositores são Athayde Filho, João Gustavo e Murilo Ventura. Abaixo a letra da canção:

Amor assim

(Comp., Athayde Filho, João Gustavo e Murilo Ventura- ano: 2016)

Talvez isso seja amar

Por desculpar seus erros

Sabendo vai errar de novo

Quem sou eu pra poder te cobrar

Olha, eu sei que não sou santo

Já te fiz perder o sono

Às vezes, quantas vezes

Eu te perdoo até perder as contas

Amor assim a gente não encontra

E quando o dia chegar vai ver

Eu troco tudo pra ficar com você

Sem nenhum problema

Será que vale a pena, hein?

Nossos defeitos se apaixonaram

É tudo simples, não tem nada errado

Eu quero ser tudo que você sonha

Amor assim a gente não encontra

Amor assim a gente não encontra

Fonte: https://m.letras.mus.br/ Matheus e Kauan/amor-assim/ Acesso em: 10. nov. de 2018.

Essa canção retrata o amor, e também por mais que tenha feito algo de errado, o "eu lírico" perdoou, isso é evidenciado nos versos, eu te perdoo até perder as contas/ amor assim a gente não encontra/ e quando o dia chegar vai ver/ 
eu troco tudo pra ficar com você/ sem nenhum problema/ será que vale a pena, hein?. O amor é "intenso" e "cego".

A dupla Fernando \& Sorocaba explicita que os artistas que vem surgindo no meio sertanejo precisam ter a preocupação em compor músicas com estilos variados, pois a indústria fonográfica está em busca de "coisas novas".

\begin{abstract}
Precisamos encorajar os artistas que estão começando a carreira no sertanejo a fazer diferente. É muito tentador seguir um modelo estético já consolidado, porque parece um atalho para o sucesso. Os músicos que estão vindo aí precisam entender, no entanto, que somente o novo vai fazer a diferença. Nós provamos isso dez anos atrás, quando começamos e tomamos o Brasil rapidamente. O compositor tem que descobrir qual papo ele consegue traduzir de maneira única. O cantor não pode se prender aos estilos vigentes. Os produtores precisam ousar, testar coisas novas (FERNANDO\& SOROCABA, 2017, p. 244).
\end{abstract}

Segundo eles, os artistas que fazem sucesso a partir de um único estilo logo serão esquecidos pela grande mídia. Faz-se necessário estarem sempre pesquisando novas temáticas, seja nos shows ou nos repertórios das canções. Pois, artistas que são bons fazem a diferença e estão sempre inovando, principalmente no ritmo das canções. Os jovens reproduziram somente três músicas, devido ao pouco tempo de descanso.

Portanto, após os momentos de descanso, que são executadas as músicas que vão desde a autêntica música raiz até a moderna música sertaneja, os foliões continuam o giro e no último dia que é consagrado como o dia dos Santos Reis, ou seja, 6 de Janeiro, tem-se a chegada da folia na casa do festeiro. Ao retratar este momento Brandão afirma que:

Há muito mais gente no pouso da entrega do que em qualquer outro. Há também mais fogos e maior solenidade. No entanto, a sequência ritual é a mesma. Os foliões aproximam-se cantando, são recebidos nos locais de passagem (arcos, portas) e entram na casa do dono (BRANDÃO, 2004, p. 371).

O último dia por ser uma festa de encerramento e que durou doze dias de jornadas diarias, costuma abranger centenas de pessoas de cidades vizinhas. Porém, nos pousos oferecidos durante os dias do giro, a quantidade é menor, 
apesar do festejo ser tradicional envolver o Catolicismo e a presença do sagrado, as pessoas estão em busca também da festa que engloba o profano, ou seja, a diversão. Conforme D’Abadia, em relação a festa, "Para alguns devotos, visitantes e moradores, é um momento de contrição, seriedade, respeito; para outros, um momento de alegria, prazer, risos" (D'ABADIA, 2014, p. 45). Os moradores ao participarem da entrega da folia estão a procura ao mesmo tempo dos rituais e da diversão que ocorre no último dia do festejo.

No dia da entrega da bandeira acontece todo o ritual, a chegada dos foliões a casa dos festeiros, aqueles que por meio da fé e crença cumpriram sua promessa de contribuir com a realização da Folia de Santos Reis. Então, os foliões cumprem com sua jornada, saudam os intrumentos, beijam a bandeira e agradecem a todos os participantes presentes durante todo o ritual. Após os agradecimentos, inicia-se a festa embalada com músicas raizes e o sertanejo moderno. Deste modo, todos se divertem ao som das musicas, tocadas com ajuda de um amplificador com grandes caixas de som e regida por um pen drive.

As canções escolhidas para o dia da festa possuem um ritmo mais acelerado, e os cantores mais tocados são Eduardo Costa e Leonardo, por trazerem em seu repertório regravações do sertanejo clássico. Já as duplas do sertanejo universitário mais tocadas são: Jads \& Jadson, Michel Teló, Fernando \& Sorocaba, Henrique \& Juliano, Matheus \& Kauan e o cantor Jefferson Moraes. A música faz com que a festa torne-se um momento único para os participantes, os foliões e a comunidade se integram finalizando com isso o ciclo religioso.

\section{CONCLUSÃO}

Diante do que foi exposto, a participação dos jovens na Folia de Santos Reis é de suma importância para a manutenção da tradição, embora o festejo tenha a presença daqueles foliões mais antigos, esse público jovem a partir de suas contribuições no momento de tocar os instrumentos e cantar trazem novas caracteristicas dentro desse espaço religioso. 
Além disso, a relação dos jovens com a música sertaneja na Folia de Santos Reis representa um momento significante, uma vez que é de práxis essa participação ser voltada em sua maioria pelos foliões mais idosos e em consequência disso, as canções serem caipiras. Com a atuação desse público jovem na festa, ela ganha um novo significado, seja por meio das músicas executadas por esse público ou até mesmo a forma como eles auxiliem na realização do festejo religioso.

Mesmo que as canções capiras tenha ganhado destaque principal nessa festividade, os jovens respeitam essa prática na folia. Ao escolherem as músicas que fazem sucesso na atualidade, recorreram ao sertanejo universitário com canções voltadas ora ao estilo mais dançante ora ao romântico. Vale ressaltar que durante a Folia de Santos Reis há as ritualidades sagradas que os foliões criam os versos expontaneamente e tem-se os momentos de descanso em que os jovens e os antigos foliões aproveitam para divertirem-se executando as músicas sertanejas. Cada qual a sua maneira e, muitas vezes, juntos.

\section{REFERÊNCIAS}

ALONSO, Gustavo. Cowboys do Asfalto: música sertaneja e modernização brasileira. 2011. Tese (Doutorado em História) -Programa de Pós-graduação em História da Universidade Federal Fluminense, Niterói, 2011. Disponível em: https://www.historia.uff.br/stricto/teses/Tese-2011_Gustavo_Alonso.pdf.Acesso em: 10. Jul.2018.

ANDRADE, Fernanda Maria Arruda dos Santos. Identidade e Religião: uma análise da construção da identidade religiosa juvenil. 2008. Dissertação (Mestrado em Ciências da Religião), Programa de mestrado em Ciências da Religião, Universidade Católica de Pernambuco, Recife, 2008. Disponível em: http://tede2. unicap.br:8080/handle/tede/291. Acesso em: 18. fev. 2021.

ANGELO, Ítalo Luiz. O Sertanejo e Suas Raízes. 2012. Trabalho de Conclusão de Curso (Bacharelado em Comunicação Social)- Instituto Municipal de Ensino Superior de Assis, Assis, 2012.Disponível em: https://cepein.femanet.com.br/ BDigital/arqTccs/0911220173.pdf. Acesso em: 12.nov.2017. 
BRANDÃO, Carlos Rodrigues. De tão longe eu venho vindo: símbolos, gestos e rituais do catolicismo popular em Goiás. Goiânia: UFG, 2004.

CATELAN. Álvaro. Viola Caipira Viola Quebrada. Goiânia: kelps, 1989.

D'ABADIA, Maria Idelma Vieira. Diversidade e Identidade Religiosa: uma leitura espacial dos padroeiros e seus festejos em Muquém, Abadiânia e TrindadeGO. Jundiaí: Paco Editorial, 2014.

DUQUE, Eduardo. Os jovens e a religião na sociedade actual: comportamentos, crenças, atitudes e valores no Distrito de Braga. Braga: Instituto Português da Juventude, 2007 (ebook). Disponível em: http://repositorium.sdum.uminho.pt/ handle/1822/24207. Acesso em: 12. jul. 2020.

FERNANDO \& SOROCABA. Ainda existem caubóis: a saga da dupla que transformou o sertanejo no ritmo mais ouvido do país. São Paulo: Paralela, 2017.

GROPPO, Luís Antonio. Juventude: ensaios sobre sociologia e história das juventudes modernas. Rio de Janeiro: Difel, 2000.

LEVI, Giovanni; SCHMITT, Jean-Claude (org.). História dos jovens. Dois volumes. São Paulo: Companhia das Letras, 1996.

Site de música (letras e áudio) - https://www.letras.mus.br/. Acesso em: 10. nov.2018.

SOFIATTI, Flávio Munhoz. Religião e juventude: os jovens carismáticos. Tese (Doutorado em Sociologia da Religião), Programa de Pós-Graduação em Sociologia da Educação, Faculdade de Filosofia, Letras e Ciências Humanas da Universidade de São Paulo, São Paulo, 2009. Disponível em: https://www.teses.usp. br/teses/disponiveis/8/8132/tde-05022010-175056/publico/FLAVIO_MUNHOZ_ SOFIATI.pdf. Acesso em: 12. jul.2021. 


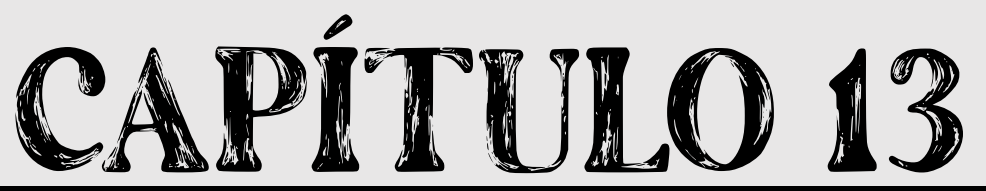

\section{TRAVESSIAS NOS (ENTRE)LUGARES: OS CAMINHOS DA JUVENTUDE EM TEMPOS PANDÊMICOS}

Tereza Caroline Lôbo João Guilherme da Trindade Curado 
Uma fronteira não é o ponto onde algo termina, mas, como os gregos reconheceram, a fronteira é o ponto a partir do qual algo começa a se fazer presente

(Martin Heidegger)

\section{INTRODUÇÃO}

Propomos, no presente capítulo, refletir sobre Juventudes nos (entre) lugares, a partir de perspectivas interdisciplinares e contemporâneas que nos remetem, geograficamente analisando, à questão do limite/fronteira que os indivíduos abarcados por tal categoria, entendida como construção social e forma de representação, transitam.

Salientamos que os (entre)lugares objetos de nossa investigação, partem de análise bibliográfica voltada para as categorias e conceitos de juventudes e jovens, recorrendo a diversas áreas do conhecimento, no intuito de uma abordagem mais consolidada e ampla. Alguns dados estatísticos, retirados em especial do site do IBGE, também serão relevantes, no que tange representatividades quantitativas do grupo em observação, tanto em nível nacional quanto considerando o recorte espacial pretendido.

O locus em questão é o município de Pirenópolis situado entre duas capitais, a do Brasil (Brasília) e a de Goiás (Goiânia), ambas planejadas e construídas de acordo com as últimas tendências da época, nos quesitos arquitetura e urbanismo, no que se diferem da colonial antiga Meia Ponte, nascida sob a égide do ouro, nas décadas iniciais do século XVIII, com a formação e aglomeração do núcleo aurífero. Tempos depois, com o declínio da população que se deslocava em procura de novos veios auríferos, a população buscou nas áreas rurais as possibilidades de sobrevivência. O significativo êxodo rural foi um movimento datado a partir da década de 1970, mesmo assim, a ruralidade se faz presente no cotidiano local. 
Assim, diante do acima exposto, retomamos ao trajeto de investigação das juventudes em Pirenópolis a partir da perspectiva de compreensão do "entre", destacada na frase inicial do parágrafo supracitado. Os (entre)lugares, como indicado, não se destacam enquanto ruptura, pelo contrário, portam-se como ligação, conforme Bhabha (1998) salienta ao abordar as "vidas na fronteira". Ainda na direção de conceitos que serão tratados ao longo do capítulo, temos a antiga denominação de Pirenópolis, Meia Ponte, cuja toponímia, segundo observações de Saint-Hilaire (1975) referencia-se a uma ponte não completa sobre o Rio das Almas, manancial responsável pelo ouro e pela povoação. O objeto que remete à antiga denominação da atual Pirenópolis, ponte, é outra possibilidade de compreender o "entre", a partir das ideias apresentadas por Heidegger (2018)1.

Diante do objetivo de buscar um panorama atual das juventudes em Pirenópolis, procuraremos destacar inicialmente alguma breve discussão sobre juventudes, recorrendo a conceitos ligados às demandas teóricas e ainda utilizando dados estatísticos partindo do final da década de 1940. Em seguida faremos rápida abordagem contextualizando os jovens nos espaços locais, especialmente os festivos em Pirenópolis. No terceiro e último momento a investigação parte do dilema da juventude contemporânea, pirenopolina ou não, viver em "tempos pandêmicos" no liminar do "antigo normal" e da "nova normalidade".

\section{O SER JOVEM ENTRE MUNDOS}

A própria definição ou mesmo consolidação do conceito de juventude é algo em construção, devido à complexidade que representa ao longo do tempo, conforme discute Ariès (1986), especialmente em "as idades da vida" que "ocupam um lugar importante nos tratados pseudocientíficos da Idade Média" (p. 33). Explica, ainda, que "como juventude significava força da idade, 'idade média', não havia lugar para a adolescência. Até o século XVIII, a adolescência

$1 \quad$ A referência aqui utilizada de "Construir, habitar, pensar" é uma tradução de Victor Hugo de Oliveira Marques publicada na Revista Multitemas, 2018, mas que será referenciada ao longo do texto com a indicação do autor e não do tradutor. 
foi confundida com a infância" (p. 41) e continua avançando no tempo até o século $X X$, período em que "a juventude apareceu como depositária de valores novos, capazes de reavivar uma sociedade velha" (p. 46-7), quando "a consciência da juventude tornou-se um fenômeno geral e banal após a guerra de 1914, em que os combates da frente de batalha se opuseram em massa às velhas gerações da retaguarda" (p. 47).

As diversidades de compreensões sobre juventude, ao longo do tempo, nos trazem para a pauta outra questão bastante relevante, o de que "construir uma definição da categoria juventude não é fácil, principalmente porque os critérios que a constituem são históricos e culturais" (DAYRELL, 2003, p. 41). Portanto, há concordância de que a "juventude é, ao mesmo tempo, uma representação sociocultural e uma situação social" (SANTANA, 2011, p. 4). Assim, é possível entender a juventude como um contexto e "o jovem como ser social", em especial considerando que:

a juventude é construída historicamente com base em fatos sociais que surgem nas relações sociais e na vida material do indivíduo. A juventude é repleta de sentidos e significados sociais dados pela sociedade em que está inserido [sic]. Submetido a esse código preestabelecido socialmente, o jovem passa a ter permissão e, por vezes, até obrigação de apresentar algumas condutas e atitudes definidas socialmente, o que provoca conflitos entre o mundo jovem e o mundo adulto (FERNANDES, 2015, p. 22236-22237 - grifo nosso).

Faz-se necessário ressaltar que os conflitos não são confinados só na fronteira dos dois mundos. Ocorre, ainda, no interior ou em dimensões outras, como os meios de comunicação, que no Brasil, "entre a segunda metade da década de 1920 e meados de 1940 demonstraram o uso restrito dos termos jovem e juventude" (SANTANA, 2011, p. 4). Cenário distinto ao esboçado por Andrade (2008, p. 25), ao afirmar que as "últimas décadas do século XX, período marcado por um extraordinário crescimento demográfico da população jovem brasileira", o que amplia os diversos espaços de presença e atuação do jovem e da juventude. Mas, vale ressaltar que "com o advento do capitalismo liberal no século $X X,(. .$.$) como toda a população, a juventude sofreu com a acumulação de$ 
capital em detrimento dos investimentos sociais" (SOUZA; PAIVA, 2012, p. 354).

Continuam, as autoras, afirmando que "observa-se, mais intensamente a partir do século XXI, que a velocidade da modernização econômica e a ênfase no imediatismo têm gerado um novo conteúdo para a representação social da experiência do 'ser jovem'” (SOUZA; PAIVA, 2012, p. 357). Nas discussões atuais há consenso de que a "juventude deve ser percebida não apenas na sua aparente unidade, mas também na sua diversidade. Não existe um conceito único de juventude. Essa não é socialmente homogênea" (CARDOSO; MELO, 2014 , p. 2). Pensar e buscar entender a "noção de juventude na perspectiva da diversidade implica, em primeiro lugar, considerá-la não mais presa a critérios rígidos (...) que ganha contornos específicos no conjunto das experiências vivenciadas pelos indivíduos no seu contexto social". Assim, há conformidade com "a noção de juventudes, no plural, para enfatizar a diversidade de modos de ser jovem existentes" (DAYRELL, 2003, p. 42).

No início da mesma centúria "de diferentes maneiras, em espaços diferentes, diversos atores passaram a falar sobre 'direitos da juventude'" (BRASIL, 2014, p. 118). Seguimos pontuando os avanços em relação às políticas ligadas à(s) juventude(s): no "ano de 2003, constituiu-se a primeira Comissão Especial de Políticas Públicas de Juventude na Câmara Federal". No ano seguinte "criouse um Grupo Interministerial para examinar as políticas dirigidas à juventude" que culminou com a criação da Secretaria Nacional de Juventude (SNJ), do Conselho Nacional da Juventude (ConJuve) e do Programa Nacional de Inclusão de Jovens (ProJovem). Ainda de acordo com a publicação da SNJ (BRASIL, 2014), os três novos avanços, foram: a atualização do Plano Nacional de Juventude em 2009; a PEC da Juventude, de 2010 e o Estatuto da Juventude, transformado em Lei em agosto de 2013.

As políticas brasileiras voltadas para as juventudes se mostraram consonantes ou mesmo extrapolaram políticas mundiais, como podemos perceber quando "em 1985 foi decretado o Ano da Juventude pelas Nações 
Unidas (BRASIL, 2014, p. 39) ou em relação à definições de faixa etária considerada pela Assembleia Geral das Nações Unidas ao definir para a América Latina a idade entre 15 e 24 anos como jovens (UNESCO, 2004), enquanto para o Brasil, a Secretaria Nacional da Juventude (SNJ) e o Conselho Nacional de Juventude (ConJuve) delimitaram jovens os que possuem entre 15 e 29 anos. Souza e Paiva explicam que (2012, p. 354) "tal variação é justificada por dois fatores: maior dificuldade de essa população ganhar autonomia - devido às aceleradas mudanças no mundo do trabalho - e aumento da expectativa de vida da população em geral”.

A população de jovens no Brasil segue curva ascendente (Tabela 1) desde a década de 1940, segundo dados do Instituto Brasileiro de Geografia e Estatística (IBGE). No entanto, vale relembrar que a ampliação brasileira para o intervalo 25 a 29 anos é algo recente, do início do século XXI.

Tabela 1 - População brasileira por grupo de idade: décadas de 1940 a 2020

\begin{tabular}{c|c|c|c|c|c}
$\begin{array}{c}\text { Grupo de } \\
\text { idade }\end{array}$ & $\mathbf{1 5}$ a $\mathbf{1 9}$ anos & $\mathbf{2 0}$ a 24 anos & $\mathbf{2 5}$ a 29 anos & Total da população \\
\hline $1940^{1}$ & 4.443 .923 & \multicolumn{2}{|c|}{$7.169 .725^{2}$} & 41.236 .315 \\
\hline $1950^{1}$ & 5.502 .315 & 4.991 .139 & 4.132 .261 & 51.944 .397 \\
\hline $1960^{1}$ & 7.142 .443 & 6.160 .742 & 5.208 .742 & 70.119 .071 \\
\hline $1970^{3}$ & 10.319 .667 & 8.398 .034 & 6.402 .341 & 93.134 .846 \\
\hline $1980^{3}$ & 13.569 .436 & 11.517 .327 & 9.449 .489 & 119.011 .052 \\
\hline $1991^{3}$ & 15.017 .472 & 13.564 .878 & 12.638 .078 & 146.825 .475 \\
\hline $2000^{3}$ & 17.949 .289 & 16.142 .935 & 13.847 .499 & 169.872 .856 \\
\hline $2010^{3}$ & 16.986 .788 & 17.240 .864 & 17.102 .917 & 190.755 .799 \\
\hline $2020^{4}$ & -- & -- & - & 211.756 .692
\end{tabular}

Elaborado pelos autores:

$1 \quad$ Fonte: https://seculoxx.ibge.gov.br

2 Fonte: https://seculoxx.ibge.gov.br - os dados relativos aos 20 a 29 anos são conjuntos

3 Fonte: https://sidra.ibge.gov.br

4 Fonte: https://cidades.ibge.gov.br - estimativa 
Os dados referentes ao recorte etário 15 a 19 anos têm um decréscimo de quase um milhão de pessoas em 2010, o que sinaliza para a diminuição de jovens nos grupos seguintes a partir de então. Tendência evidenciada em diversos outros países e que contribui no incremento de políticas públicas, como algumas mencionadas acima. Outra característica pela qual a juventude pode ser analisada é o período de nascimento, que dá origem às denominadas "Gerações" que apresentam características distintas em diversas áreas e que têm sido utilizadas também para explicar aspectos diferenciados da juventude.

Figura 1 - Gerações, a partir da década de 1940

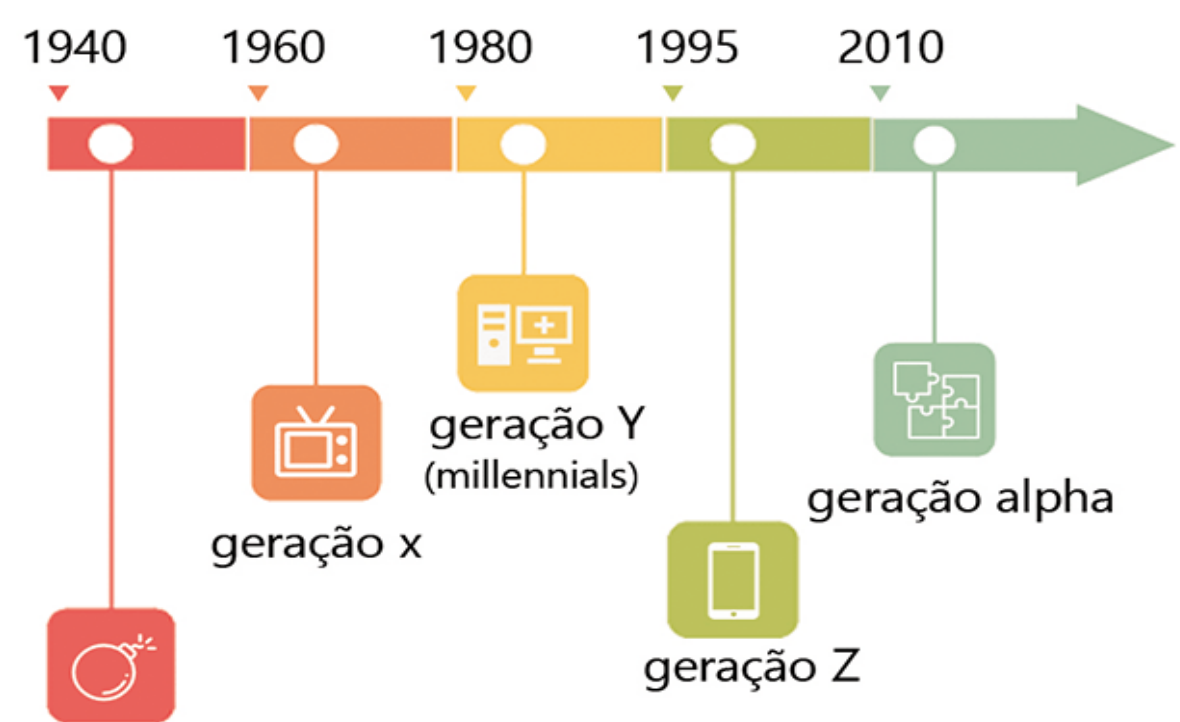

baby boomers

Fonte: https://www.colegioconstelacao.com.br

Destaque aqui para o aprimoramento das tecnologias digitais a partir da década de 1990, contexto de surgimento das redes sociais, um (entre)lugar situado entre o mundo público e o privado, que tornou-se local em que os jovens se encontram, mantém diálogos virtuais, à distância, e que notabilizou como possibilidade cada vez mais constante e ampliada durante o isolamento social presencial, imposto pela pandemia de COVID-19.

A Comissão Organizadora Nacional (CON) da $4^{a}$ Conferência da Juventude, em consideração aos riscos causados pela pandemia do novo 
coronavírus, decidiu em votação, adiar a Conferência para este ano de 2021 (https://conferenciajuventude.mdh.gov.br). As demandas dirigidas à juventude já não eram poucas, com a pandemia foram potencializadas, somadas a falta de políticas públicas de construção do futuro desses jovens.

\section{SER JOVEM EM PIRENÓPOLIS}

Ao aproximar da vida social no município de Pirenópolis, especificamente o lugar da juventude na cultura local, intui-se procurar nos "padrões culturais os elementos definidores de uma existência humana" (GEERTZ, 2019, p. 27). Uma existência cotidiana que destaca o fato de estar vivo em tempos de pandemia.

Pirenópolis é uma cidade feita de festas, cujos saberes locais, as experiências coletivas e as práticas subjetivas garantem as identidades territoriais e as identidades religiosas dos sujeitos envolvidos. As festividades, fundadas numa religiosidade católica popular, instituíram no calendário local variados festejos ao longo do ano: Folia de Santos Reis, Festa de São Sebastião, Festas Juninas, Festa do Morro, Festa da Padroeira, Festa do Bonfim, dentre outras. Nosso foco será o festejo maior e mais representativo para a cultura local, que é a festa do Divino Espírito Santo, inscrita no Livro de Registro das Celebrações em 13 de maio de 2010, como Patrimônio Cultural do Brasil (IPHAN, 2017). Discorrendo sobre a salvaguarda dos festejos, destacando sua sustentabilidade e continuidade, assim é definida esta celebração:

por aglutinar várias temporalidades, espacialidades e sociabilidades, a Festa do Divino em Pirenópolis, celebração constituída por um grande número de festejos que remontam às memórias coletivas do passado que se ressignificam no presente, transmitindo, assim, os conhecimentos dos detentores dos bens intangíveis às novas gerações. Tais fatos levam em consideração que para a realização da Festa alguns "saberes e fazeres" são fundamentais, por isso a valorização e o reconhecimento de cada elemento é indispensável para a sustentabilidade da mesma (LÔBO, A., CURADO, LÔBO, T., 2020, p. 206).

Este fenômeno festivo se dá num tempo e num espaço próprios. O tempo é o da colheita, Pentecoste, acontece desde o século XIX; o espaço é múltiplo 
e dinâmico, pois, está impregnado de memórias, constituído de identidades, alimentado de afetos e de emoções. É uma festividade conhecida e reconhecida pela população local por propiciar, por intermédio de seus rituais, várias formas de estar presente na festa. Há espaços para todos, principalmente para a juventude, foco desta análise.

Encontrar pessoas, aglomerar, dançar, cantar, deslocar pelos espaços são ações características de uma festividade popular, mas, que são atuações restringidas e até proibidas neste momento em que se vivencia uma pandemia, assim, o isolar e se fechar em casa é o recomendável. O distanciamento social incide sobre a dinâmica da Festa como um todo e especificamente sobre a juventude, segmento atuante e responsável em grande parte pela perpetuação das manifestações festivas.

Praticar as comemorações ao Divino Espírito Santo, ou melhor festejá-lo, é uma prática presente na cultura local a quase três séculos e, neste espaço de tempo muitos espaços foram criados e utilizados para dar sentido a esta celebração que compõe as memórias coletivas e individuais e mantem viva as tradições locais. Nestas multiplicidades de espaços e de tempos encontrase todo tipo de experiências humanas e trajetórias de vida que desafiam nossa compreensão.

Dentre as co-presenças na Festa estão os jovens, que ao acompanhar os giros e pousos das folias, portar um estandarte em um dos cortejos, desfilar pelas ruas mascarados, frequentar as improvisadas e concorridas boates ou "ranchão" como são conhecidos, dentre outras inúmeras formas de presença na Festa, criam seus espaços de participação e de vivência. Aqui a presença/participação pode ser também entendida como a "ponte que reúne" (HEIDEGGER, 2018, p. 285).

A não realização da Festa, suspensa por decretos de várias instâncias, levou a comunidade a se utilizar das tecnologias e dos diversos ambientes virtuais, para manifestar sua relação com as festividades. Assim, 
a realização de lives com as novenas e missas festivas com apresentação das músicas tradicionais em latim com Coral e orquestra reduzidos, e traslados com a Coroa do Divino e as bandeiras em carros abertos pelas ruas da cidade. A equipe de comunicação da Paróquia Nossa Senhora do Rosário promoveu entrevistas com vários participantes da Festa, que foram disponibilizadas em redes sociais oficiais da Paróquia durante os momentos anteriormente reservados às festividades. Outro grupo de pessoas organizou no sábado do Divino o Ranchão virtual das Cavalhadas, uma maneira das pessoas poderem ouvir as músicas mais recorrentes do Ranchão, o que atraiu grande parte da juventude pirenopolina. A Banda Phoenix, reduzida, fez uma única alvorada seguindo o trajeto oficial, mas não divulgada com antecedência, para evitar aglomeração. Mascarados saíram às ruas ao meio dia de sábado, durante a tarde do Domingo do Divino, sozinhos, em duplas ou em pequenos grupos. Porém, na segunda-feira, o grupo de mascarados índios saiu em multidão e acabou tendo problemas, devido às restrições impostas em decorrência da situação atual de pandemia (LÔBO, A., CURADO, LÔBO, T., 2020, p. 219-220).

Nos anos em que os festejos aconteceram "normalmente", foram inumeráveis as formas de situar e atuar nos diversos espaços festivos, as ações e as compreensões das atuações criaram as identidades e os sentidos dados à Festa. Este mundo relacional, internalizado no sujeito e essencialmente subjetivo desvelam o espaço Pirenópolis no seu momento de Festa. Desse modo, a juventude pirenopolina, tem nos festejos do Divino, uma das formas de produção de espaços e de relações pessoais e interpessoais com o mundo circundante. Mas, quando a Festa não é realizada por causa do coronavírus, para onde vão os jovens? Estes vão constituir outros espaços de encontros e representações, seja o ciberespaço, conforme relato anterior, cuja presença física não é necessária, e/ ou as aglomerações clandestinas.

Neste momento em que as tradições da Festa não podem ser vivenciadas, pelos fatos citados, e as orientações de ficar em isolamento social também não são respeitadas, surgem os (entre)lugares, os espaços estrategicamente criados para negociar novas formas de atuação no espaço que não são os da Festa do Divino, que não aconteceram, e nem os espaços impostos pela pandemia, o confinamento. O arranjo espacial definido no (entre)lugar separa a juventude dos demais membros da comunidade e permite o encontro entre seus pares. Esta fronteira, equivalente ao sertão de Guimarães Rosa onde "tudo é e não 
é", estabelece outros sentidos, novos valores, pois, é um momento específico de pandemia que não representa o que era e que não ficará para sempre. Este momento dinâmico de passagem busca novos pertencimentos, mas também clama pelas permanências.

\section{JUVENTUDE(S) EM TRAVESSIAS}

Compreendendo o indivíduo e a dinâmica de suas relações como indissociáveis da sociedade e do espaço de atuação buscamos, para além do visível, discutir onde estão os jovens nestes pandêmicos anos de 2020 e 2021 ? Ao produzir o complexo de relações pessoais e interpessoais os indivíduos produzem a sociedade e também seus espaços de vida. Assim, os espaços são palcos onde as relações são engendradas e ao mesmo tempo são produtos destas relações. Interessa-nos, analisar como a juventude atual tem produzido seus espaços de relações e que tipo de relações têm sido forjadas nas vivências com estes espaços.

Harvey ao tratar o espaço como palavra-chave inspirado em Raymond Williams, diz que "aquilo que nós fazemos, tanto quanto o que compreendemos, é integralmente dependente do quadro espaço-temporal primário dentro do qual nós nos situamos" (2006, p. 16 e 17).

A pandemia da COVID-19 que estamos vivenciando, é um marco temporal e, para além da sua influência na saúde física e emocional das pessoas, tem atuado, principalmente, nas relações entre os indivíduos e nos espaços de vida da sociedade. Espaços de relações comumente frequentados pelos jovens como as escolas, as casas de parentes e amigos, as academias, os bares, dentre outros, que deixaram de ser os locais comuns de encontros e aglomerações da juventude para se tornarem locais, muitas vezes, proibidos ou com restrições, interferindo diretamente nas relações entre os jovens e nas formas como estes até então produziam sua existência.

Pensar na volta da normalidade ou "um novo normal", talvez não seja um caminho promissor. O modo de viver e de compreender a vida foram alterados e 
o passado não volta.

É difícil saber o que fazer com o passado. Você não pode viver nele, não importa o quanto fantasie estar fazendo isso ou o quão seriamente nostálgico você se torne ao relembrá-lo. Você não pode prever o futuro a partir dele, por mais promissor, sugestivo ou sinistro que possa parecer; as coisas iminentes muitas vezes não acontecem, as que não se insinuam com frequência se sucedem (...) não há, de fato, um fio condutor. Sua única utilidade (além, isto é, e talvez principalmente, da simples avaliação que se faça dele no que diz respeito àquilo por que as pessoas passaram) parece ser perceber, um pouco menos vagamente, o que está a acontecer em volta, reagindo, de modo um pouco mais inteligente, àquilo que, no caso, surge à vista (GEERTZ, 2012, p. 136).

São nos espaços do cotidiano que os jovens atuam e agem se relacionando consigo mesmo, com os lugares à sua volta e com o mundo, numa relação de criação e apropriação de espaços, de memórias, de identidades, materializadas ou não no espaço. Mas que reproduzem a vida no e com o lugar, e têm mantido viva uma cultura engendrada no ciclo da mineração do ouro em Goiás, ainda no século XVIII, e se apresenta de forma densa na atualidade.

Nosso recorte está circunscrito ao município de Pirenópolis, local que habitamos, e que pelas limitações do momento não nos permite uma observação mais densa. O fenômeno da pandemia provocada pela COVID-19 e sua relação com a juventude em Pirenópolis, cidade goiana com população estimada, 2020, de 25.064 habitantes, em sua maioria na faixa etária entre 10 a 29 anos (IBGE, 2010) e moradores na área urbana (figura 2).

A cultura local reserva espaços específicos para atuação dos jovens e isso têm contribuído para a manutenção e atualização das tradições culturais. A presença de jovens nos rituais das festas é imprescindível para que estas continuem a serem reproduzidas.

Além do envolvimento dos jovens com as tradições do município, temse ainda a relação destes com as atividades ligadas ao turismo. A cidade de Pirenópolis é um polo de atração turística desde a década de 1990, e a partir de então tem sido fonte de trabalho e atuação da juventude. Sabemos que o turismo, enquanto atividade capitalista, alimenta fluxos de mercadorias e pessoas e que 
as interações produzidas por estes fluxos foram afetadas para conter ou retardar a disseminação da doença. Assim, ao pensarmos os jovens pirenopolinos, segmento representativo da população local (Figura 2) - e suas relações no tempo e no espaço, percebemos que estes foram afetados nas suas interações de lazer e trabalho. Desse modo, questiona-se: como estes jovens têm produzido e reproduzido sua existência diante dos fatores que se colocam na atualidade que os afetaram diretamente?

Figura 2 - Pirâmide Etária, Pirenópolis/GO, 2010

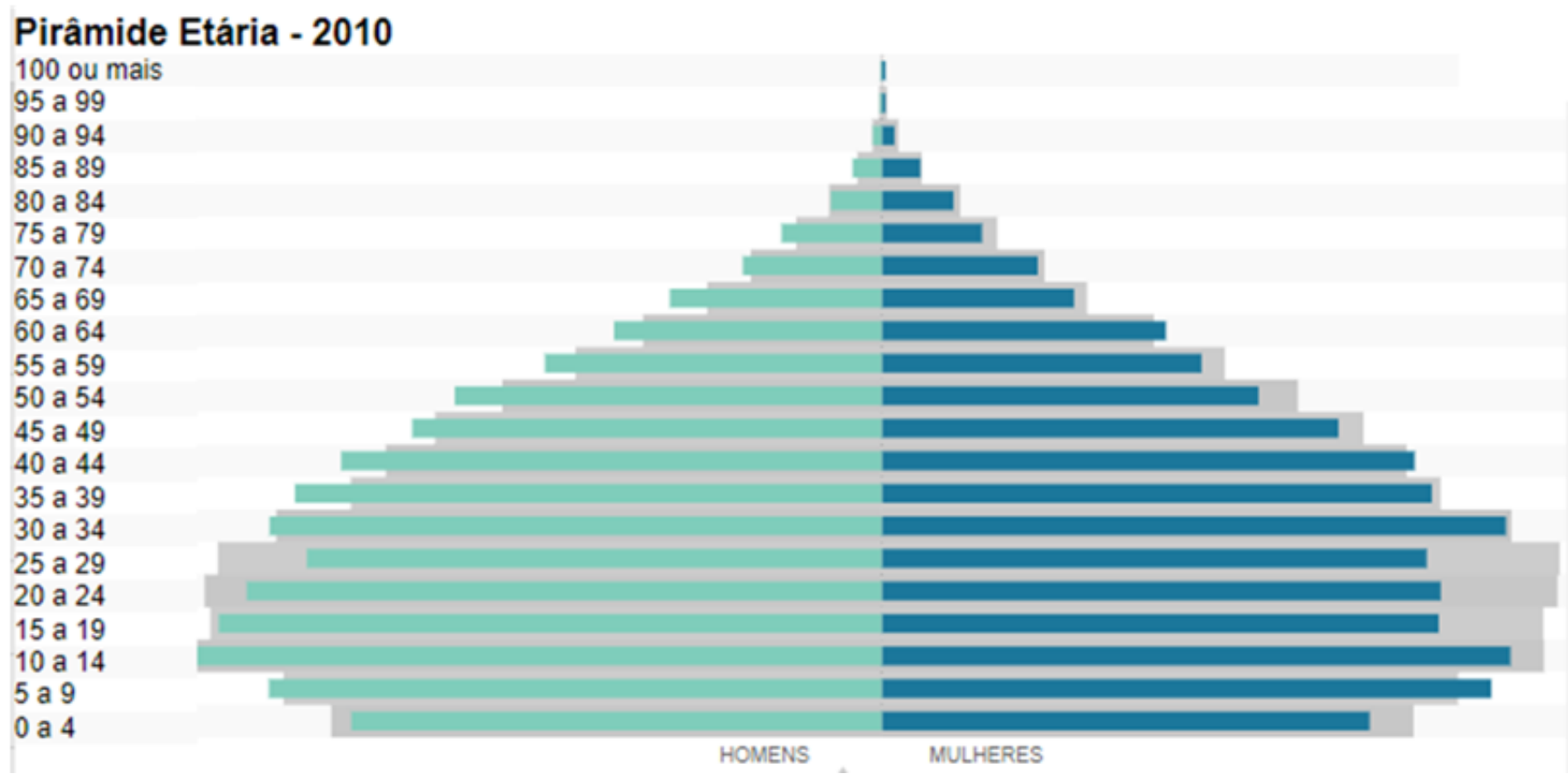

Fonte: https://cidades.ibge.gov.br/brasil/go/pirenopolis/panorama

A pandemia tem transformado significativamente as ações das pessoas empreendidas sobre o espaço, os fluxos humanos do cotidiano foram alterados, foi preciso evitar aglomeração para não se contaminar e levar o vírus para casa e infectar os familiares. Na pequena e histórica cidade de Pirenópolis, a realidade não foi diferente, num primeiro momento as barreiras sanitárias inibiram as atividades turísticas - pousadas e bares desativados - escolas fechadas com aulas remotas, jovens sem trabalho e a expectativa de que tudo passaria rapidamente. No entanto, não foi o que aconteceu, e para piorar a situação, o marco temporal cultural do município, momento aguardado pelos pirenopolinos, 
mas principalmente pelos jovens, a Festa do Divino Espírito Santo com suas folias e festividades, foram suspensas nos anos de 2020 e 2021.

O tempo pandêmico se prolongou e espaços das relações humanas precisaram ser criados e/ou reinventados. As redes sociais foram as responsáveis, num primeiro momento, pelo intercâmbio entre as pessoas, os espaços virtuais para encontros e vivências. Festas de aniversários, por exemplo, eram realizadas pelo google meet, o que possibilitava a cada indivíduo, fixado na sua janelinha, interagir com os parentes e amigos. Permitiu ainda a realização de algumas celebrações do Divino Espírito Santo.

Por outro lado, a ampla capacidade de comunicação destas redes, que conecta espaços individuais e privados tornando-os públicos e relacionais permitiram o planejamento e a divulgação também das festas clandestinas (Figura 3 ), assim chamadas por burlar as regras dispostas nos decretos de controle da disseminação do vírus da COVID-19 e no entendimento da necessidade de distanciamento social.

Os jovens, ávidos por voltar a transitar nos espaços de lazer e de trabalho retornando ao ritmo de deslocamentos próprio da juventude, ou seja, desenvolveram novos espaços para seus encontros, espaços que produziam aglomerações e quase sempre sem adoção dos itens de proteção como o uso de álcool em gel, máscaras e o distanciamento social.

Os flagrantes de festas clandestinas são mostrados em vídeos e fotos pelo Instagram em todas as regiões do país, desafiando as autoridades e a letalidade do vírus. O comportamento é explicado pela necessidade que jovens e adolescentes têm de encontrar amigos fisicamente, é próprio desta fase da vida. Os lugares comumente de encontros entre esses jovens foram remodelados para não chamar a atenção das autoridades, foram frequentes as baladas em casas alugadas por temporada em bairros residenciais e áreas rurais em Pirenópolis (Figura 4). 
Figura 3 - Festas clandestinas em pauta no G1Goiás e Jornal Anhanguera

\section{Festa beneficente causa aglomeração em Pirenópolis; vídeo}

Entrada para o evento era doação de alimentos. Prefeitura da cidade informou que bar deve ser multado.

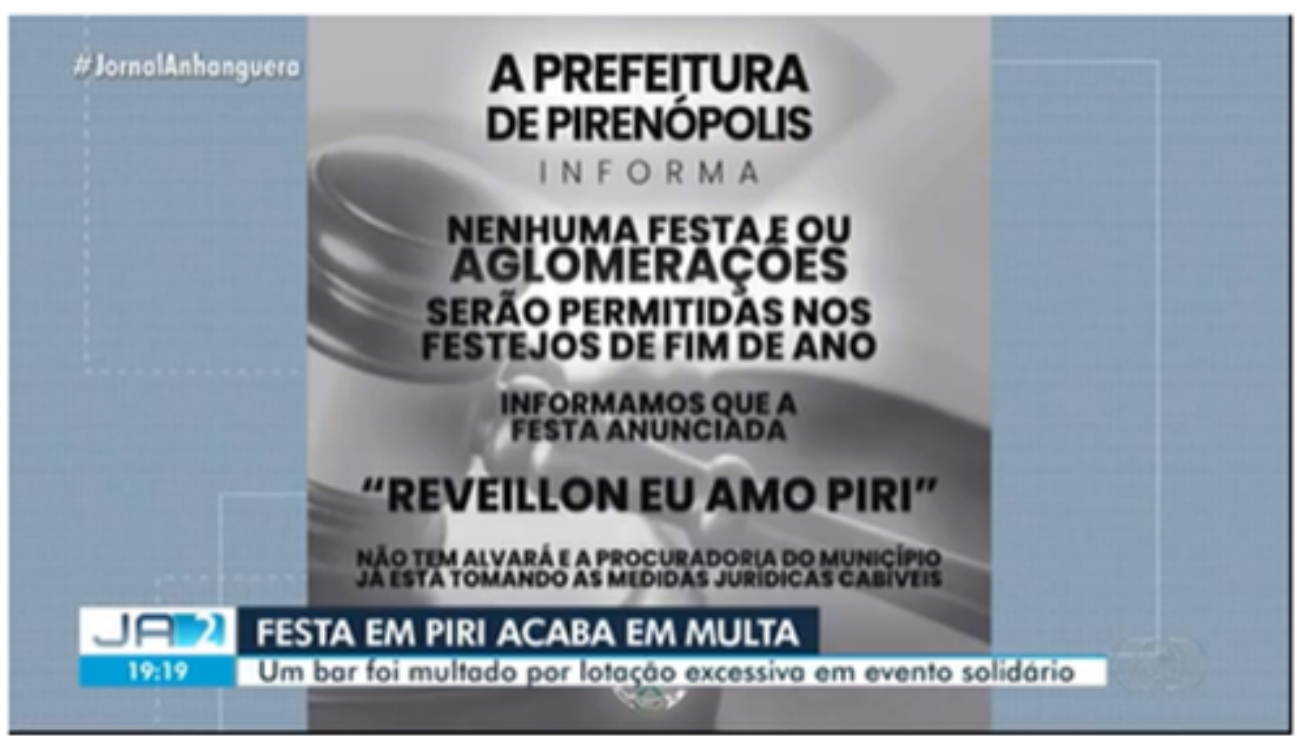

Fonte: https://g1.globo.com/go/goias/noticia/2020 
Figura 4 - Repercussão de festa clandestina em Pirenópolis

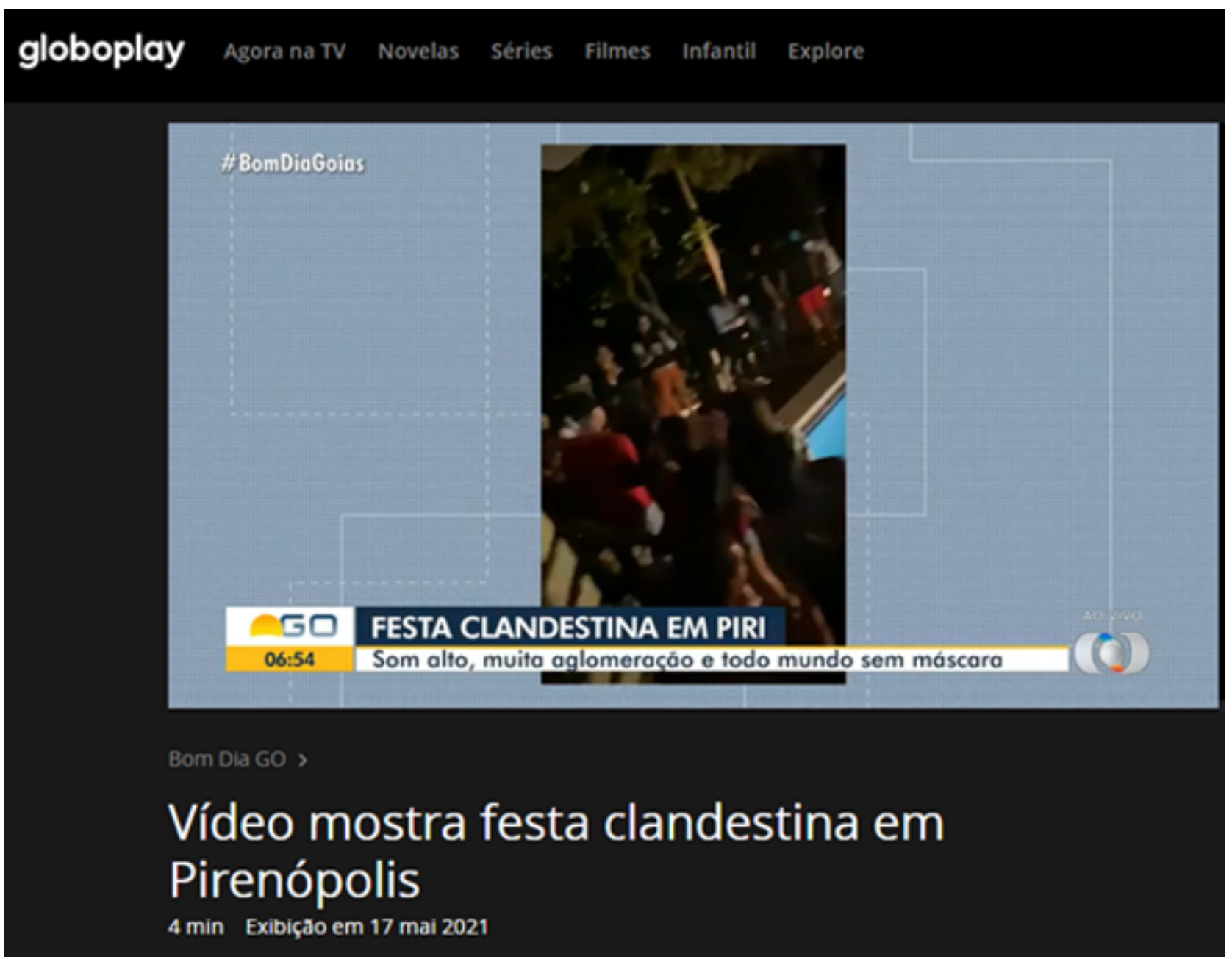

Fonte: https://globoplay.globo.com

As transformações resultantes das ações dos jovens no espaço, neste momento analisado, possibilitam um mergulho na Geografia com a utilização de concepções de espaço que não estão circunscritas somente ao espaço físico absoluto, como apresentado por Harvey onde

as escolhas são claras no espaço e tempo absolutos, mas elas se tornam mais fluidas quando passamos ao espaço-tempo relativo, e muito difíceis em um mundo relacional. Mas é somente dentro deste último quadro que nós podemos nos confrontar com numerosos aspectos da política contemporânea, na medida em que se trata de um mundo de subjetividade e de consciências políticas (2006, p. 17).

As práticas ou as relações de poderes costurados neste espaço Pirenópolis constituíram um tecido social permeados de lugares, assim temos os lugares de trabalho, os lazer e festas, os de moradias, os públicos; aqui o foco está nos 
diversos espaços de atuação dos jovens resultantes da convivência com seus pares e com os demais atores sociais, que constroem pontes que "acompanham aqui e ali o hesitante e precipitado caminho dos homens (HEIDEGGER, 2018, p. 285).

E, para além, pensando o espaço de forma relacional, "então ele é a soma de todas as nossas conexões e, neste sentido, absolutamente estabelecido, e essas conexões podem seguir ao redor do mundo" (MASSEY, 2008, p. 260). Estas relações estão conectadas com o mundo - especificamente nas maneiras como o mundo tem lidado com a pandemia da COVID-19 - sofrendo uma variedade de influências e reagindo de formas múltiplas.

Estes espaços contingentes e suas fronteiras são também o local do embate, do encontro com o outro, dos extremos que suscitam aporte nas relações de poder surgidas nestes (inter)lugares, poderes emanados do Estado e das redes de "micropoderes", aportando em Foucault e que, "tendo existência própria e formas específicas no nível mais elementar" (MACHADO, 2015, p.17) servem aqui para explicar a sociedade e o momento que vivemos. A referência aos poderes não quer dizer somente a repressão e expulsão da vida social, mas o controle de ações e potencialidades, o "objetivo ao mesmo tempo econômico e político" (MACHADO, 2015, p. 20), pois, estas contravenções festivas mantêm a dinâmica do comércio local e turístico, e, simultaneamente, legitima a volta ao mercado de trabalho desses jovens festeiros em meio a uma das maiores epidemias da história da humanidade.

Destarte, “o que Foucault chamou de 'microfísica do poder' significa tanto um deslocamento do espaço da análise quanto do nível em que esta se efetua" (MACHADO, 2015, p.14), as alterações nas relações cotidianas mais simples servirão para uma compreensão ampliada de atuação da juventude nestes tempos de clausuras e confinamentos.

O isolamento social traz novamente as relações de poder para o centro das discussões, pois, ainda segundo Foucault, o "poder disciplinar" é um instrumento que tem como alvo o corpo humano, "manipula seus elementos, produz seu 
comportamento, enfim, fabrica o tipo de homem necessário ao funcionamento e à manutenção da sociedade industrial, capitalista" (MACHADO, 2015, p. 21 e 22). No limiar destes tempos de pandemia a relação do poder e dos micropoderes, com os corpos jovens, têm produzido modificações comportamentais e psíquicas imensuráveis até o momento, o que torna indefinido que tipo de pessoas resultarão deste processo.

Isso permite pensar também nos questionamentos e nas ações de resistências sobre este momento pandêmico, como a juventude tem (re)significado seu modo de ser e estar no mundo. Portanto, reproduzimos o questionamento: "pode emergir uma nova racionalidade pós pandemia, que se expressaria em uma transformação cultural significativa?" (ROCHA, 2020, p. 60).

É prematuro dizer o que permanecerá das representações da Festa do Divino e também o que se apresentará como novo. Da mesma forma, não é possível falar sobre que juventudes estão sendo gestadas na singularidade deste tempo e espaço que estamos vivenciando. No entanto, uma afirmação é possível, isto é o desafio de "ser-no-mundo" (HEIDEGGER, 2009), pois como relembra Bhabha (1998, p. 20) "é na emergência dos interstícios - a sobreposição e o deslocamento de domínios da diferença - que as experiências intersubjetivas e coletivas (...) são negociados". Voltando à ponte, Heidegger (2018, p. 284) afirma que "na travessia, a ponte toca a margem primeiramente como margem à frente"; para tanto, o caminho, "digo: o real não está na saída nem na chegada: ele se dispõe para a gente é no meio da travessia" (GUIMARÃES ROSA, 2019, p. 53).

\section{CONCLUSÃO}

A vida não para! Viver é preciso e, viver com o outro, estar em sociedade. Desse modo, onde e como estão os jovens, neste momento, diante das orientações e restrições impostas pelos decretos legais e pelo entendimento comum de proteção contra a transmissão do vírus da COVID-19, foi o que tentamos transcrever nestas poucas páginas. Enxergamos estes jovens no (entre)lugar, vivendo o cotidiano e/ou agindo na clandestinidade, fato noticiado 
frequentemente pelos meios de comunicação, para produzir seus encontros e manter suas relações.

Ao propomos um pequeno momento de reflexão sobre as ações da juventude em tempo de crise, especificamente em meio a pandemia do novo coronavírus, buscamos dialogar com teóricos que pensam a produção do espaço - local e global - e suas interações com o indivíduo e seus grupos.

Optamos pelo recorte circunscrito ao município de Pirenópolis, local que habitamos, cidade goiana com população estimada, 2020, de 25.064 habitantes, em sua maioria jovens entre 10 a 29 anos (IBGE, 2010) e moradores na área urbana. Pelas limitações do momento não foi possível uma observação mais densa sobre o fenômeno da pandemia provocada pela COVID-19 e sua relação com a juventude pirenopolina.

Entendemos que a juventude, enquanto uma categoria de análise apresenta características comuns passíveis de generalizações, mas, caminhamos no sentido de compreender a extensão geográfica das relações sociais do mundo que estamos inseridos e as implicações na nossa existência.

Como professores da rede pública estadual de ensino e com décadas de trabalho dedicadas à formação de jovens - moradores tanto da cidade quanto da área rural - do Ensino Básico, aliada a quase vinte anos de pesquisas científicas sobre a cultura local, especificamente as festas populares e suas redes participações, é que propomos pensar este momento de crise social focado neste espaço que atuamos e com os jovens com os quais convivemos.

\section{REFERENCIAS}

ANDRADE, Carla Coelho de. Juventude e trabalho: alguns aspectos do cenário brasileiro contemporâneo. In: Mercado de Trabalho (IPEA), n. 37, p. 25-32, nov. 2008. Disponível em: <http://repositorio.ipea.gov.br/bitstream/11058/4077/1/ bmt37_09_juventude_e_trabalho.pdf>. Acesso em 30 jun. 2021.

ARIÈS, Philippe. História social da criança e da família. 2. ed. Trad. Dora Flaksman. Rio de Janeiro: Ed. Guanabara, 1986. 
BHABHA, Homi. O local da cultura. Trad. Myriam Ávila; Eliana Reis e Gláucia Gonçalves. Belo Horizonte: Ed. UFMG, 1998.

BRASIL. Estação Juventude: conceitos fundamentais - ponto de partida para uma reflexão sobre políticas públicas de juventude. ABRAMO, Helena (Org.). Brasília: SNJ, 2014. Disponível em: <https://bibliotecadigital.mdh.gov.br/jspui/ bitstream/192/69/1/SNJ_conceitos_fundamentais_2014.pdf>. Acesso em 30 jun. 2021.

CARDOSO, Letícia de Freitas; MELO, Mônica Aparecida Soares Silva de. Uma abordagem sociológica do conceito de juventude - ou seria... Jovens e Juventudes? In: Anais do $8^{\circ}$ Fórum FEPEG, 4p, 2014. Disponível em: http:// www.fepeg2014.unimontes.br/sites/default/files/resumos/arquivo_pdf_anais/ conceito_de_juventude_-_fepeg-2014.pdf. Acesso em 02 jul. 2021.

DAYRELL, Juarez. O jovem como sujeito social. In: Revista Brasileira de Educação, n. 24,. p. 40-52, set/dez, 2003. Disponível em: < https://www.scielo.

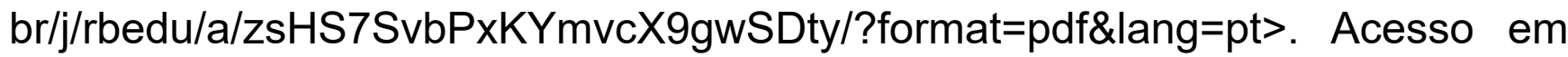
30 jun. 2021.

FERNANDES, Ivone de Souza. Juventude: uma categoria sócio-histórica. In: Anais do XII Congresso Nacional de Educação. Paraná, 2015. p. 22232-22245. Disponível em: https://educere.bruc.com.br/arquivo/pdf2015/17672_8290.pdf. Acesso em 30 jun. 2021.

FOUCAULT, Michel. Microfísica do poder. Organização, introdução e revisão técnica de Roberto Machado. 2. ed. Rio de Janeiro: Paz e Terra, 2015.

GEERTZ, Clifford. Atrás dos fatos: dois países, quatro décadas, um antropólogo. Trad. Denise Jardim Duarte. Petrópolis, Rio de Janeiro: Vozes, 2012.

GEERTZ, Clifford. A interpretação das culturas. Rio de Janeiro: LCT, 2019.

GERAÇÕES A PARTIR DE 1940. Disponível em: <https://www. colegioconstelacao.com.br/post/as-gera\%C3\%A7\%C3\%B5es-x-y-z-e-alpha-esuas-caracter\%C3\%ADsticas-qual-a-sua-gera\%C3\%A7\%C3\%A3o>. Acesso em 03 ago. 2021.

GLOBOPLAY. Festa clandestina em Piri. Disponível em: <https://globoplay. globo.com/v/9521024/>. Acesso em 10 ago. 2021. 
GUIMARÃES ROSA, João. Grande sertão: veredas - . "O diabo na rua, o meio do redemoinho". 22. ed. São Paulo: Companhia das Letras, 2019.

G1. Festa clandestina causa aglomeração em Pirenópolis. Disponível em: $<$ https://g1.globo.com/go/goias/noticia/2020/12/12/festa-beneficente-geraaglomeracao-e-bar-e-multado-por-cinco-infracoes-em-pirenopolis.ghtml>. Acesso em 10 ago. 2021.

HARVEY, David. O espaço como palavra-chave. In: Castree, N.; Gregory, D. (Orgs.) David Harvey: a critical reader. Trad. livre: Letícia Gianella. Malden e Oxford, 2006. Disponível em: < https://www.e-publicacoes.uerj.br/index.php/revistaempauta/article/view/18625/13595>. Acesso em 30 jun. 2021.

HEIDEGGER, Martin. Ser e tempo. Trad. Márcia Sá Cavalcante Schuback; posfácio de Emmanuel Carneiro Leão. 4. ed. Petrópolis: Vozes, 2009.

HEIDEGGER, Martin. Construir, habitar, pensar. Trad. Victor Hugo de Oliveira Marques. Multitemas. Campo Grande/MS. v. 23, n. 53, p. 275-294, 2018. Disponível em: < https://www.multitemas.ucdb.br/multitemas/article/view/1593>. Acesso em 29 jun. 2021.

IBGE. Censo Brasil: 1940, 1950 e 1960. Disponível em: <https://seculoxx.ibge. gov.br/populacionais-sociais-politicas-e-culturais/busca-por-temas/populacao. html>. Acesso em 01 ago. 2021.

IBGE. Censo Brasil: 1970, 1980, 1991, 2000 e 2010. Disponível em: <https:// sidra.ibge.gov.br/tabela/200\#resultado 1970 a 2010>. Acesso em 02 ago. 2021.

IBGE. Estimativa populacional para o ano de 2020. Disponível em: <https:// cidades.ibge.gov.br/brasil/panorama 2020>. Acesso em 02 ago. 2021.

IPHAN. Dossiê Festa do Divino Espírito Santo de Pirenópolis - Goiás. Brasília: Iphan, 2017.

LÔBO, Aline Santana; CURADO, João Guilherme da Trindade; LÔBO, Tereza Caroline. Festa do Divino Espírito Santo de Pirenópolis/Goiás: salvaguarda. In: Instituto do Patrimônio Histórico e Artístico Nacional (IPHAN). Práticas de gestão. Brasília: IPHAN, 2020. (Série Cadernos de Salvaguarda de Bens Registrados; n.1) 
MACHADO, Roberto. Introdução: por uma genealogia do poder. In: FOUCAULT, Michel. Microfísica do poder. Organização, introdução e revisão técnica de Roberto Machado. 2. ed. Rio de Janeiro: Paz e Terra, 2015. p. 7-34.

MASSEY, Doreen B. Pelo espaço: uma nova política da espacialidade. Trad. Hilda Pareto Maciel, Rogério Haesbaert. Rio de Janeiro: Bertrand Brasil, 2008.

ROCHA, Lai Bronzi. Espiral capitalista e geografia em tempos de pandemia de 2020. Revista Ensaios de Geografia. Niterói, vol. 5, n. 10, p. 56, 2020. Disponível em: <https://periodicos.uff.br/ensaios_posgeo/article/view/42539/pdf>. Acesso em 05 jul. 2021.

SAINT-HILAIRE, Auguste de. Viagem à Província de Goiás. Trad. Regina Régis Junqueira. Itatiaia/EdUSP, Belo Horizonte/São Paulo, 1975.

SANTANA, Márcio Santos de. A categoria Juventude na pesquisa histórica: notas metodológicas. In: Anais do XXVI Simpósio Nacional de História. São Paulo, 10p, 2011. Disponível em: http://www.snh2011.anpuh.org/resources/ anais/14/1312378682_ARQUIVO_MarcioSantosdeSANTANA.pdf. Acesso em 10 jul. 2021.

SOUZA, Candida de; PAIVA, Ilana Lemos de. Faces da juventude brasileira: entre $\mathrm{o}$ ideal e o real. Estudos de Psicologia. n. 17, v. 3, p. 353-360, 2012. Disponível em: <https://www.scielo.br/j/epsic/a/ ZBY9r5KFD5c7QnhzpZ6CVDk/?lang=pt\&format=pdf>. Acesso em 30 jun. 2021.

UNESCO. Políticas públicas para/com juventude. Brasília: UNESCO, 2004. 


\section{SOBRE OS ORGANIZADORES}

\section{RAFAEL RIBEIRO DOS SANTOS}

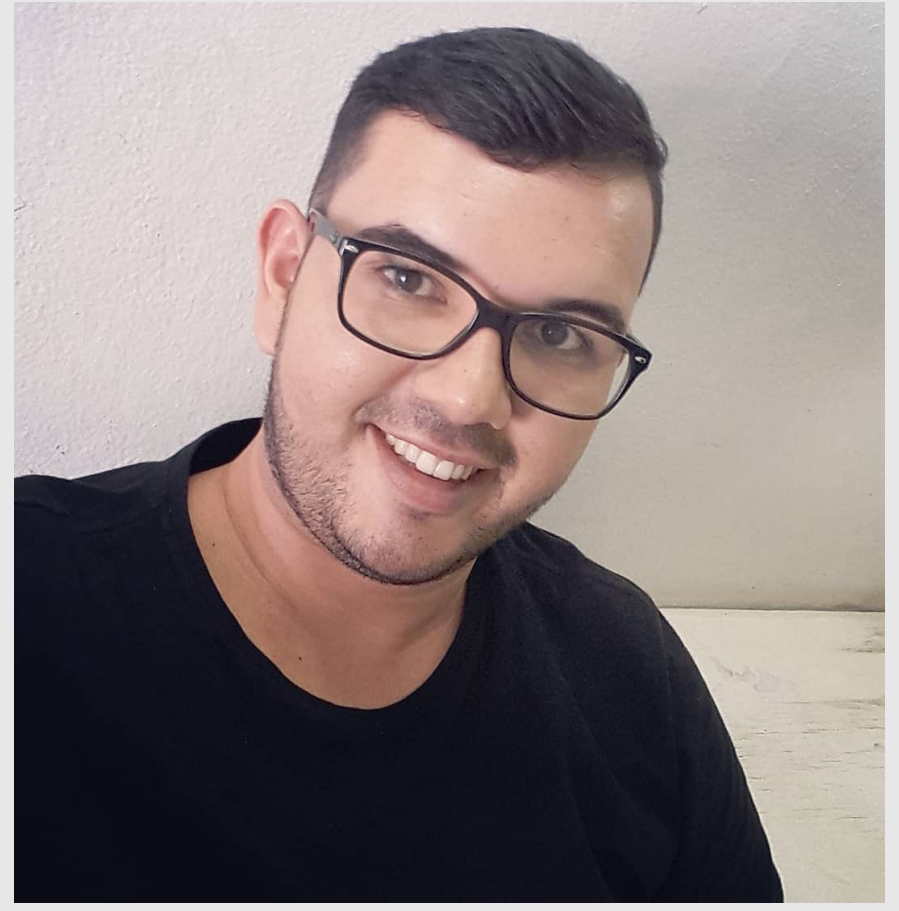

Mestrando em Ciências Sociais e Humanidades pelo Programa de Pós-Graduação Stricto Sensu Interdisciplinar em Territórios e Expressões Culturais no Cerrado(PPGTECCER) da Universidade Estadual de Goiás (UEG). Graduado em Geografia (licenciatura) pela UEG, Unidade Universitária de Anápolis - Ciências Socioeconômicas e Humanas (UnUCSEH) (2019). Bolsista de Pós-Graduação Stricto Sensu - nível mestrado da UEG, aprovado no edital n. 1/2020. Membro do Núcleo de Pesquisa em Ensino de Cidade (NUPEC), Instituto de Estudos Socioambientais (IESA) da Universidade Federal de Goiás (UFG). Atuou como tutor no Centro de Ensino e Aprendizagem em Rede (CEAR) da UEG (2020). Já participou como voluntário em um cursinho pré-vestibular, certificado como projeto de extensão pela UnUCSEH/UEG, voltado para o atendimento de alunos de baixa renda, intitulado Projeto Educação Aberta (PrEA) (2016-2017). Foi membro de dois grupos de estudos, sendo um no âmbito da Geografia Cultural e o outro Geografia Urbana, ambos de 2016 a 2017. Participa de pesquisas nas áreas da Geografia e Interdisciplinar, com experiência em Ensino de Geografia; Geografia Cultural; Geografia Urbana; e Saberes e Expressões Culturais do Cerrado, atuando nos seguintes temas: cultura, lugar, prática docente, juventudes, território e cidades. 


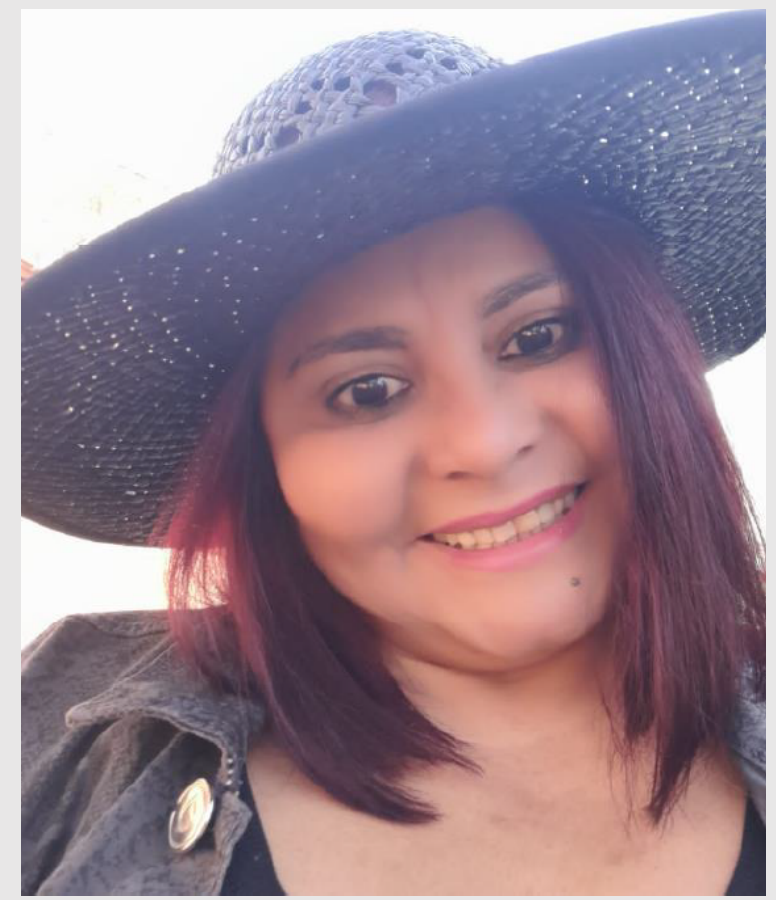

Possui Pós-Doutorado em Geografia pela Universidade Federal de Juiz de Fora (UFJF) (2019). Doutora em Geografia pela Universidade Federal de Goiás (UFG) (2013). Mestre em Geografia Humana pela Universidade de São Paulo (USP) (2001). Graduada em Geografia (licenciatura e bacharelado) pela Universidade Federal do Ceará (UFC) (1994). Professora Estatutária Adjunto Nível II da Universidade Estadual de Goiás (UEG) em regime de dedicação em tempo integral à docência e à pesquisa (RTIDP). Atua como docente no Programa de Pós-graduação Stricto Sensu Interdisciplinar em Territórios e Expressões Culturais no Cerrado (PPGTECCER) e no curso de Geografia (licenciatura) da Unidade Universitária de Anápolis - Ciências Socioeconômicas e Humanas (UnUCSEH) da UEG. Atuou como professora colaboradora do Programa de Pós-Graduação em Estudos Culturais, Memória e Patrimônio (PROMEP) do Campus Cora Coralina da UEG. Pesquisadora externa do Laboratório de Estudos e Pesquisas das Dinâmicas Territoriais (LABOTER), vinculado ao Instituto de Estudos Socioambientais (IESA) da Universidade Federal de Goiás (UFG). Coordenadora do Centro Interdisciplinar de Estudos África-Américas (CieAA), lotado na UnUCSEH/ UEG. Desenvolve pesquisas no âmbito da Geografia e Interdisciplinar, com experiência na Geografia Cultural; Geografia Urbana; e Saberes e Expressões Culturais do Cerrado, atuando em uma perspectiva pós-colonial, tendo como principais temáticas: religiões de matriz africana (candomblé), relações étnico-raciais, processos diaspóricos, território, territorialidades, poder e cidades. 


\section{SOBRE AS AUTORAS E OS AUTORES}

\section{Amanda Beatriz Silva de Godoi}

Mestre em Sociologia pelo Programa de Pós-Graduação em Sociologia (PPGS) da Faculdade de Ciências Sociais (FCS) da Universidade Federal de Goiás (UFG). Graduada em História pela Universidade Estadual de Goiás (UEG), Unidade Universitária de Anápolis - Ciências Socioeconômicas e Humanas (UnUCSEH). E-mail: godoiamanda2016@gmail.com.

\section{Ademir Luiz da Silva}

Doutor em História pela Universidade Federal de Goiás e professor da Universidade Estadual de Goiás. Presidente da União Brasileira de Escritores Seção Goiás. E-mail: alsconclave@gmail.com

\section{Bianca Isabel Pederiva}

Graduanda em Psicologia e Bolsista de Iniciação Científica pelo Grupo de Pesquisa Currículo, Espaço, Movimento (CEM/CNPq/Univates) da Universidade do Vale do Taquari - Univates. E-mail: bianca.pederiva@universo.univates.br.

\section{Brunna Thais Reis Sales}

Graduada e Licenciada em Educação Física, pela Universo-GO. Especialista em Fisiologia do Exercício e Prescrição de Exercício, e em Psicomotricidade. Mestre em educação, pela PUC-GO, e Doutoranda em Educação, pela PUC-GO. Bolsista da Capes. Professora da rede municipal em Senador Canedo. E-mail: brunnasales86@hotmail.com

\section{Bruna Molina Leal}

Psicóloga, licenciada em Ciências Sociais, Mestre em Psicologia Social e Institucional, Técnica em Assuntos Educacionais da Universidade Federal do Rio Grande do Sul, membro do Núcleo de Estudos e Pesquisas em Processos Institucionais, Coletivos e de Subjetivação (NEPPICS-UFRGS).

E-mail: bruna.m.leal@gmail.com.

\section{Benhur Pinós da Costa}

Professor do departamento de Geociências e Programa de Pós-Graduação em Geografia da Universidade Federal de Santa Maria - UFSM, Coordenador do Laboratório de Espacialidades Urbanas - LabEU.

E-mail: benpinos@gmail.com 


\section{Cláudia Valente Cavalcante}

Doutora em Educação, docente do Programa de Pós-graduação em Educação e do curso de Pedagogia da Escola de Formação de Professores e Humanidades da PUC Goiás. E-mail: clavalente@pucgoias.edu.br

\section{Carla Pizzuti Savian}

Bolsista de iniciação científica no Laboratório de Espacialidades Urbanas labEU, graduanda em Geografia pela Universidade Federal de Santa Maria UFSM. E-mail: carlapizzutisavian@hotmail.com

\section{Gracielle de Souza Silva}

Mestranda em Ciências Sociais e Humanidades pelo Programa de Pós-Graduação Stricto Sensu Interdisciplinar em Territórios e Expressões Culturais no Cerrado (PPGTECCER) da Universidade Estadual de Goiás (UEG). Bolsista de Mestrado da Coordenação de Aperfeiçoamento de Pessoal de Nível Superior (CAPES). Especialista em Educação Ambiental: perspectivas interdisciplinares e tecnológicas pela UEG, Licenciada em Geografia pela UEG, Unidade Universitária de Anápolis - Ciências Socioeconômicas e Humanas (UnUCSEH). E-mail: gracielle.guichard@gmail.com

\section{João Guilherme da Trindade Curado}

Doutorado e Mestrado em Geografia IESA/UFG. Graduação em História (UniEvangélica). Grupo de Pesquisa Geografia Cultural: Territórios e Identidade (UFG). E-mail: joaojgguilherme@gmail.com

\section{Joana D'arc Bardella Castro}

Possui Pós-Doutorado e Doutorado em Economia pela Universidade de Brasília (UnB); Mestrado em Economia de Empresas pela Universidade Católica de Brasília (UCB); Especialista em Assessoria Linguística e Revisão Textual pela Universidade Estadual de Goiás (UEG); Especialista em Química e em Elaboração Análise e Avaliação de Projetos pela Universidade Estadual de Anápolis (UNIANA); Especialista em Metodologia do Ensino Superior pela Faculdade de Ciências Econômicas de Anápolis (FACEA); e Graduada em Ciências Econômicas pela UEG. Docente da UEG, atuando nos Programas de Pós-Graduação Stricto Sensu Interdisciplinar em Territórios e Expressões Culturais no Cerrado (PPGTECCER) e no de Recursos Naturais do Cerrado (PPGRENAC); bem como na Graduação em Ciências Econômicas da Unidade Universitária de Anápolis - Ciências Socioeconômicas e Humanas (UnUCSEH). E-mail: joanabardellacastro@gmail.com. 


\section{Jefferson Dias Andrade de Jesus}

Mestrando em Ciências Sociais e Humanidades pelo Programa de Pós-Graduação Stricto Sensu Interdisciplinar em Territórios e Expressões Culturais no Cerrado (PPGTECCER) da Universidade Estadual de Goiás (UEG). Graduado em Geografia (licenciatura) pela UEG, Unidade Universitária de Anápolis Ciências Socioeconômicas e Humanas (UnUCSEH). Bolsista de Mestrado da UEG. E-mail: jeffersondiasgeo@gmail.com.

\section{Katiele Hundertmarck}

Mestra em Saúde Materno Infantil (UFN), Especialista em Saúde de Adolescentes (Unyleya), Enfermeira (UFSM) no Instituto Federal de Educação, Ciência e Tecnologia Farroupilha Campus Júlio de Castilhos.

E-mail:katielehun@gmail.com.

\section{Luís Paulo Cruz Borges}

Professor Adjunto no Instituto de Aplicação Fernandes Rodrigues da Silveira da Universidade do Estado do Rio de Janeiro (CAp-UERJ). Possui Doutorado em Educação pelo Programa de Pós-Graduação em Educação da Universidade do Estado do Rio de Janeiro (ProPEd/UERJ).

E-mail: borgesluispaulo@yahoo.com.br

\section{Marco Antônio Oliveira Lima}

Licenciado em Educação Física pela Regional Catalão/UFG, atual Universidade Federal de Catalão/UFCat. Doutorando em Educação na Pontifícia Universidade Católica de Goiás. Professor de Educação Física no Instituto Federal de Goiás - Campus Águas Lindas de Goiás.

E-mail: marcobasquetebol@gmailcom

\section{Mary Anne Vieira Silva}

Pós-Doutorado em Geografia pela Universidade Federal de Juiz de Fora (UFJF), Doutorado em Geografia pela Universidade Federal de Goiás (UFG), Mestrado em Geografia pela Universidade de São Paulo (USP) e Graduada em Geografia (licenciatura e bacharel) pela Universidade Federal do Ceará (UFC). Professora efetiva da Universidade Estadual de Goiás (UEG), atuando no curso de Geografia (licenciatura) da Unidade Universitária de Anápolis - Ciências Socioeconômicas e Humanas (UnUCSEH) e no Programa de Pós-Graduação Stricto Sensu Interdisciplinar em Territórios e Expressões Culturais no Cerrado (PPGTECCER). E-mail: mary.silva@ueg.br. 


\section{Mirelle Antônia Souza Freitas}

Mestranda no Programa de Pós-Graduação interdisciplinar em Ciências Sociais e Humanidades: Territórios e Expressões Culturais no Cerrado, da Universidade Estadual de Goiás Unidade Universitária de Anápolis Ciências Socioeconômicas e Humanas (UnUCSEH). Bolsista de Mestrado da Coordenação de Aperfeiçoamento Pessoal de Nível Superior (CAPES). Especialista em Psicopedagogia Institucional e clínica pela Faculdade Católica de Anápolis. Graduada em História (licenciatura) Universidade Estadual de Goiás. E- mail: mirelli.a.f@hotmail.com

\section{Nair Iracema Silveira dos Santos}

Psicóloga, Doutora em Educação, professora aposentada da Universidade Federal do Rio Grande do Sul. E- mail: nair.iracema@gmail.com.

\section{Naomi Cambará Barbosa}

Bolsista de iniciação científica no Laboratório de Espacialidades Urbanas labEU, graduanda em Geografia pela Universidade Federal de Santa Maria UFSM. E-mail: nan.barbosa01@gmail.com

\section{Rafael Ribeiro dos Santos}

Mestrando em Ciências Sociais e Humanidades pelo Programa de Pós-Graduação Stricto Sensu Interdisciplinar em Territórios e Expressões Culturais no Cerrado (PPGTECCER) da Universidade Estadual de Goiás (UEG). Graduado em Geografia (licenciatura) pela UEG, Unidade Universitária de Anápolis Ciências Socioeconômicas e Humanas (UnUCSEH). Bolsista de Mestrado da UEG. Membro do Núcleo de Pesquisa em Ensino de Cidade (NUPEC) do Instituto de Estudos Socioambientais (IESA) da Universidade Federal de Goiás (UFG). E-mail: rafaelribeiro.geografia@gmail.com.

\section{Rita Castorina Gonçalves Gundim Lemes}

Mestranda em Ciências Sociais e Humanidades pelo Programa de Pós-Graduação Stricto Sensu Interdisciplinar em Territórios e Expressões Culturais no Cerrado (PPGTECCER) da Universidade Estadual de Goiás (UEG). Especialista em Metodologia do Ensino de Filosofia e Sociologia, e em Neuropsicopedagogia, ambas pela Faculdade Futura. Graduada em Pedagogia pela Unifacvest. Graduada em História (licenciatura) pela UEG, Unidade Universitária de Anápolis - Ciências Socioeconômicas e Humanas (UnUCSEH). Professora da Rede Estadual de Educação de Goiás. E-mail: rita.gundim@hotmail.com. 


\section{Rosemarie Gartner Tschiedel}

Psicóloga, Doutora em Psicologia Social (PUC-SP), docente do Departamento de Psicologia Social e Institucional e do Programa de Pós-Graduação em Psicologia Social e Institucional do Instituto de Psicologia da Universidade Federal do Rio Grande do Sul. Coordenadora do Núcleo de Estudos e Pesquisas em Processos Institucionais, Coletivos e de Subjetivação (NEPPICS-UFRGS). E-mail: rosetschiedel@gmail.com.

\section{Suzana Feldens Schwertner}

Psicóloga (Universidade Federal do Rio Grande do Sul). Doutora em Educação (Universidade Federal do Rio Grande do Sul). Docente do Programa de Pós-Graduação em Ensino (Universidade do Vale do Taquari - Univates). Docente do curso de Psicologia (Universidade do Vale do Taquari - Univates). Coordenadora do Grupo de Pesquisa Juventudes, Imagem e Educação (JImE/ $\mathrm{CNPq}$ ). Pesquisadora do Grupo Currículo, Espaço, Movimento (CEM/CNPq/ Univates. E-mail: suzifs@univates.br.

\section{Tereza Caroline Lôbo}

Doutorado e Mestrado em Geografia IESA/UFG. Graduação em Ciências Sociais (UniEvangélica). Grupo de Pesquisa Geografia Cultural: Territórios e Identidade (UFG). E-mail: terezacarolinelobo@gmail.com 
www.arcoeditores.com
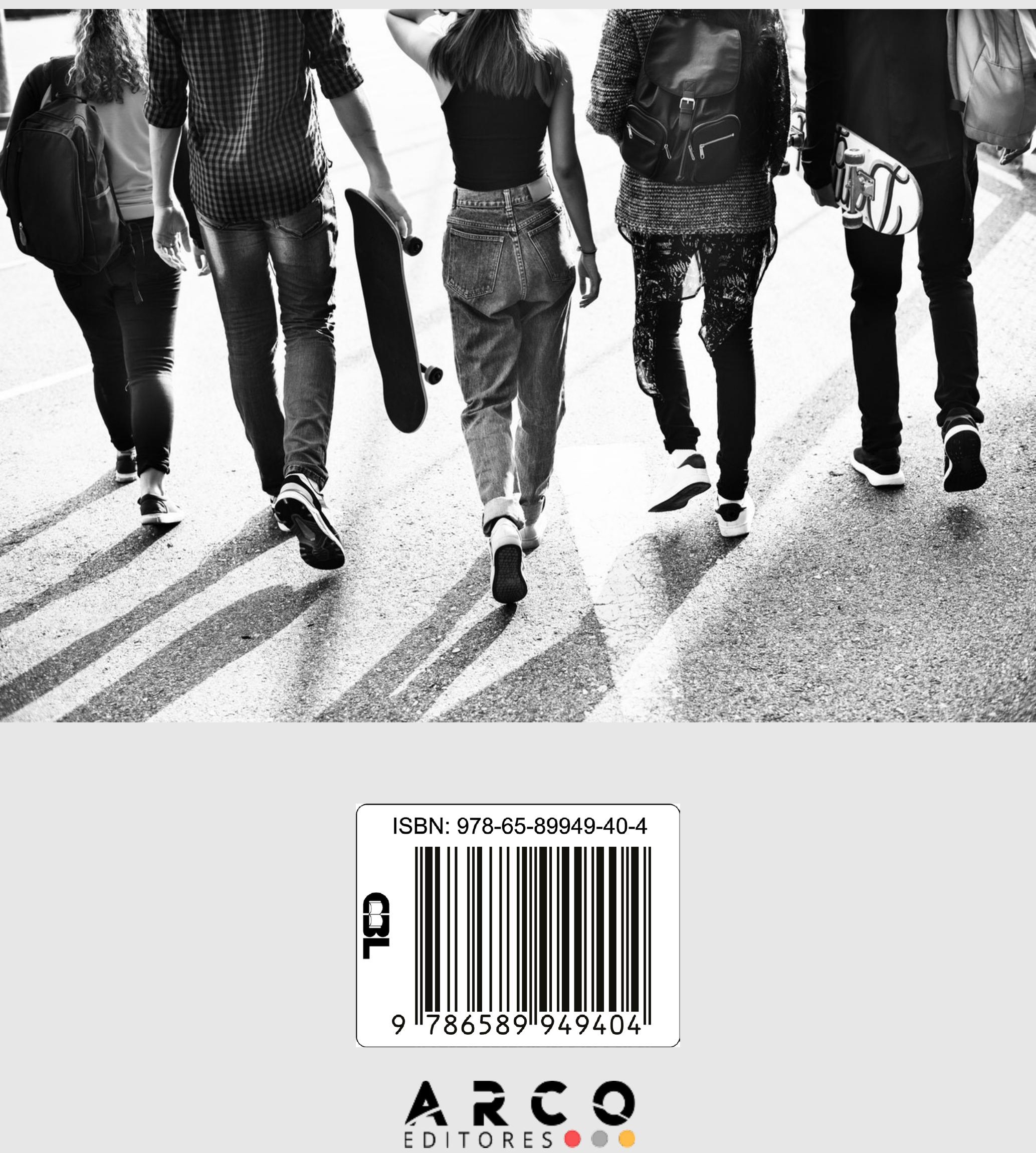